\title{
The Northeast Heating Fuel Market: Assessment and Options
}

\author{
July 2000
}

Office of Integrated Analysis and Forecasting

\author{
Office of Policy
}

Energy Information Administration

U.S. Department of Energy

U.S. Department of Energy

Washington, DC 20585

Washington, DC 20585

This report was prepared jointly by the Energy Information Administration and the Office of Policy, U.S. Department of Energy. The Executive Summary, except for policy recommendations, and Chapters 1 through 5 were prepared by the Energy Information Administration. The policy recommendations and initiatives in Chapter 6 and in the Executive Summary were prepared by the Office of Policy. The Energy Information Administration, the independent statistical and analytical agency within the Department of Energy, does not make or recommend any energy policies and did not participate in the development of the recommendations contained in Chapter 6. 


\section{Contacts}

The analysis in this report was undertaken at the request of the Secretary of Energy, Bill Richardson. The principal purpose of this study is to examine the feasibility and impacts of converting factories and other major users of heating oil to different fuels, and to discuss other options that may mitigate future heating oil supply problems in the Northeast.

Chapters 1 through 5 and the Executive Summary of this report, except for policy recommendations, were prepared by staff from the Office of Integrated Analysis and Forecasting and the Office of Oil and Gas, in the Energy Information Administration (EIA). The remainder of the report was prepared by the Office of Policy, U.S. Department of Energy. General questions concerning the report may be directed to Andy S. Kydes (akydes @eia.doe.gov, 202/586-2222), Senior Advisor and Project Leader; Mary J. Hutzler (202/586-2222), Director, Office of Integrated Analysis and Forecasting; James M. Kendell (202/586-9646), Director, Oil and Gas Division; or Joan Heinkel (202/586-4650), Director, Natural Gas Division.

Specific questions about the analysis may be directed to the following EIA staff:

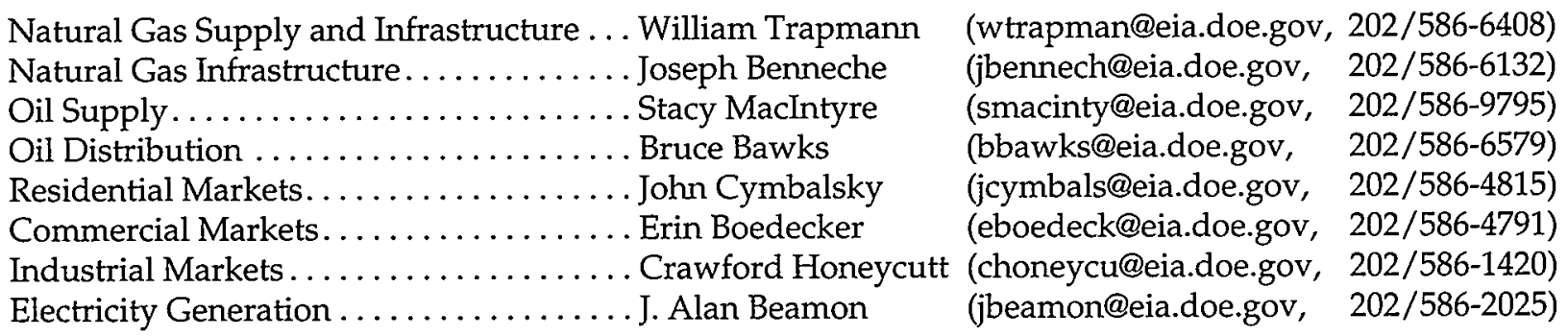

In addition, Robert Latta and Alan Swenson of the Office of Energy Markets and End Use provided assistance with residential and commercial sector data.
Questions concerning policy initiatives and recommendations in this report may be directed to Elizabeth Campbell, Office of Policy, U.S. Department of Energy (202/586-4444, elizabeth.campbell@hq.doe.gov). 


\section{DISCLAIMER}

This report was prepared as an account of work sponsored by an agency of the United States Government. Neither the United States Government nor any agency thereof, nor any of their employees, make any warranty, express or implied, or assumes any legal liability or responsibility for the accuracy, completeness, or usefulness of any information, apparatus, product, or process disclosed, or represents that its use would not infringe privately owned rights. Reference herein to any specific commercial product, process, or service by trade name, trademark, manufacturer, or otherwise does not necessarily constitute or imply its endorsement, recommendation, or favoring by the United States Government or any agency thereof. The views and opinions of authors expressed herein do not necessarily state or reflect those of the United States Government or any agency thereof. 


\section{DISCLAIMER}

Portions of this document may be illegible in electronic image products. Images are produced from the best available original document. 


\section{Contents}

Executive Summary $\ldots \ldots \ldots \ldots \ldots \ldots \ldots \ldots \ldots \ldots \ldots \ldots \ldots \ldots \ldots \ldots \ldots \ldots$

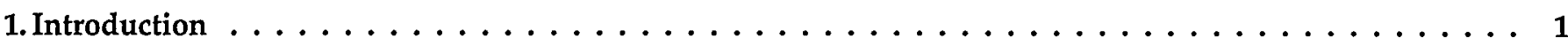

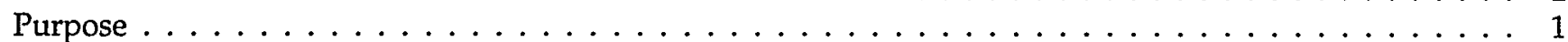

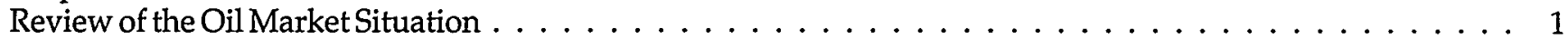

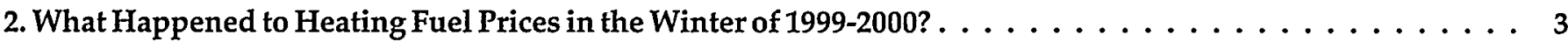

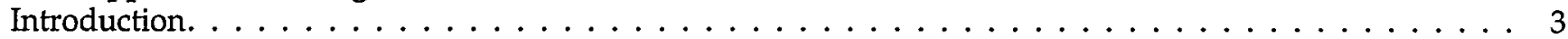

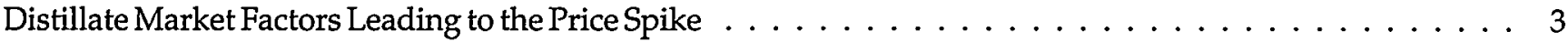

Crude Oil and Product Stocks Declined in 1999. . . . . . . . . . . . . . . . . . . . 3

U.S. Distillate Stocks Fell Below Normal in December $1999 \ldots \ldots \ldots \ldots$. . . . . . . . . . . . . . . . 4

Natural Gas Market Factors Contributing to Distillate Fuel Oil Price Increases . . . . . . . . . . . . . . 7

The January/February 2000 Price Spike . . . . . . . . . . . . . . . . . . . . . . . . . 9

Northeast Heating Oil and Natural Gas Spot Prices Spiked as Low Stocks Fell Further. . . . . . . . . . . 9

Weather Conditions Drove January Demand . . . . . . . . . . . . . . . . . . . . 9

The Supply Situation Deteriorated While Demand Grew . . . . . . . . . . . . . . . . . 12

A Number of Events Eventually Corrected the Imbalance. . . . . . . . . . . . . . . . . . 12

What Will the Future Bring? . . . . . . . . . . . . . . . . . . . . . 12

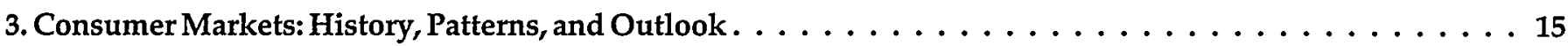

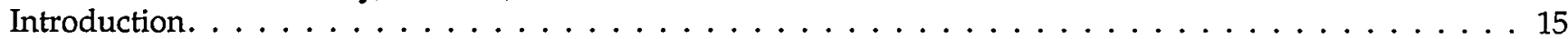

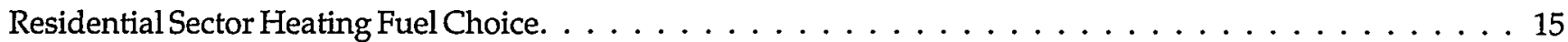

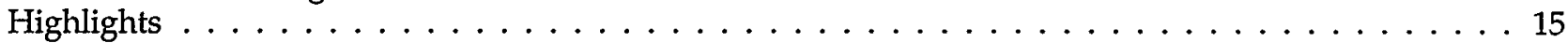

Recent Trends and Current Use of Distillate Fuel Oil in the Residential Sector . . . . . . . . . . . . . 16

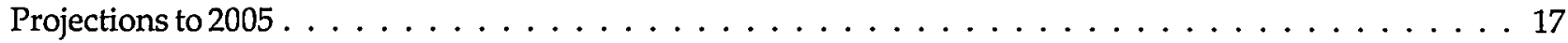

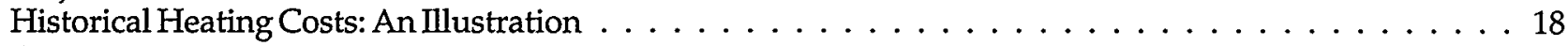

Conservation Options. . . . . . . . . . . . . . . . . . . . . . . . . . . 19

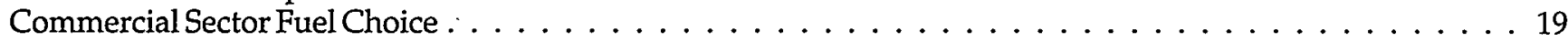

Highlights . . . . . . . . . . . . . . . . . . . . . . . . . . . . . . 19

Recent Trends and Current Use of Distillate Fuel Oil in the Commercial Sector . . . . . . . . . . . . . 20

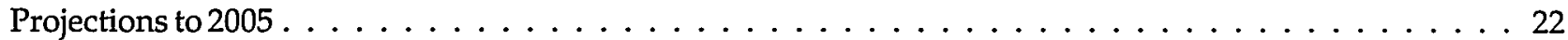

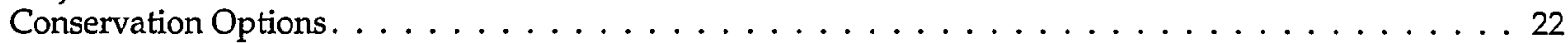

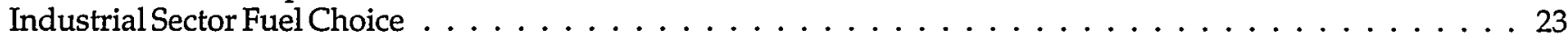

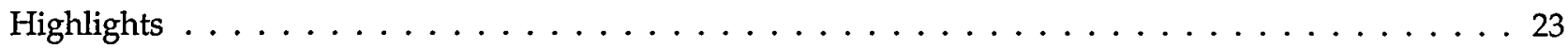

Recent Trends in Industrial Distillate Fuel Oil Consumption . . . . . . . . . . . . . . . . . . 24

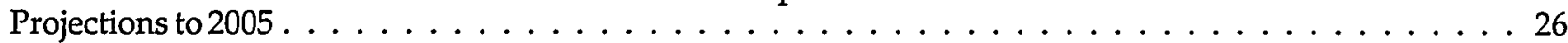

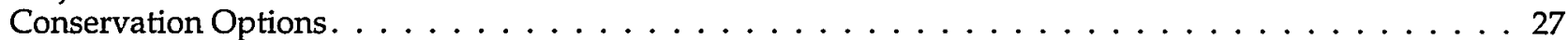

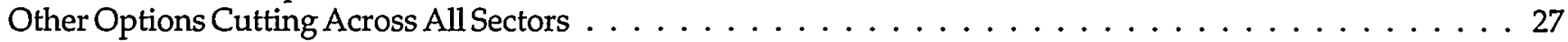

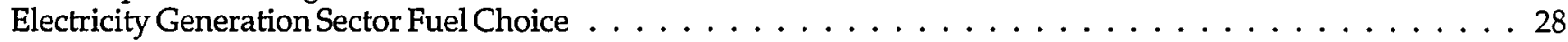

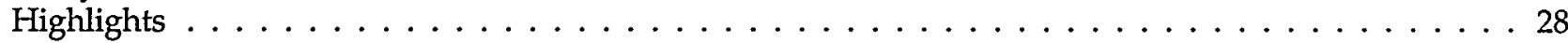

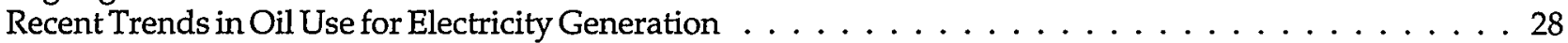

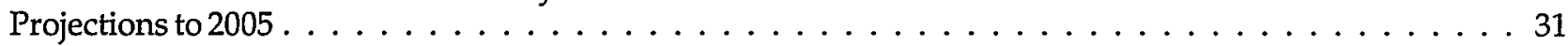

Fuel Supply Options for Electricity Generators . . . . . . . . . . . . . . . . . . . . . 32

Northeast Distillate Fuel Oil Market Summary . . . . . . . . . . . . . . . . . . . . . 33

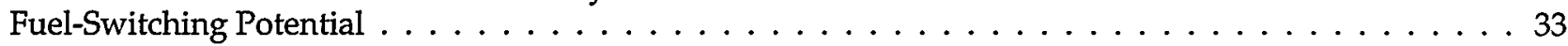

Conversion of Distillate Fuel Oil Use to Other Fuels . . . . . . . . . . . . . . . . . 35 


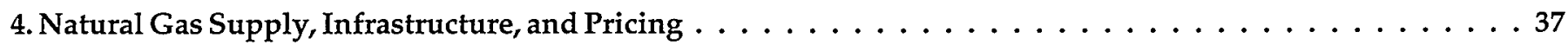

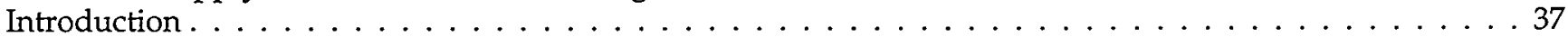

CurrentStatus of the Natural Gas Industry in the Northeast . . . . . . . . . . . . . . . . . . 37

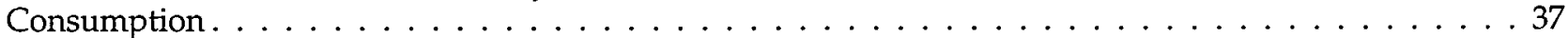

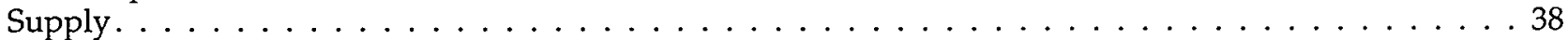

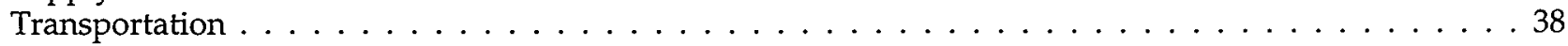

Storage and Local Distribution . . . . . . . . . . . . . . . . . . . . 40

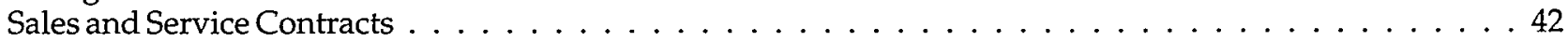

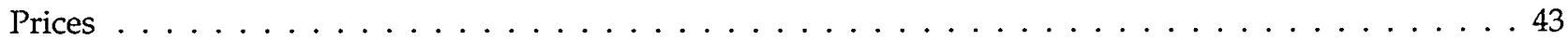

Evaluating the Effects of Changes in Natural Gas Consumption Patterns . . . . . . . . . . . . . . . 43

Pipeline Capacity Requirements . . . . . . . . . . . . . . . . . . . . . . 45

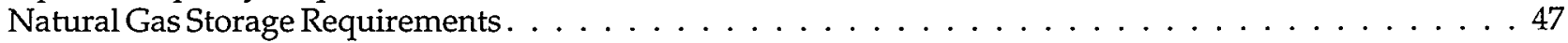

Economic and Institutional Obstacles to Gas Conversion . . . . . . . . . . . . . . . . . . 48

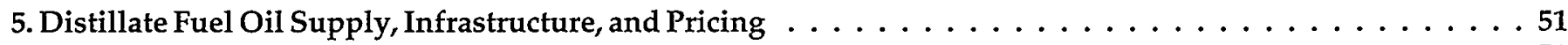

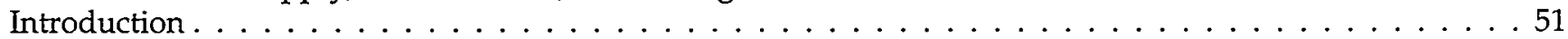

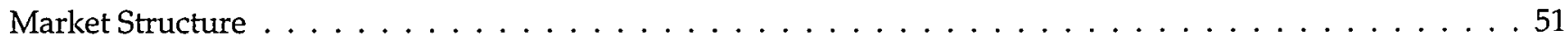

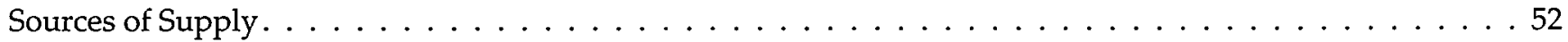

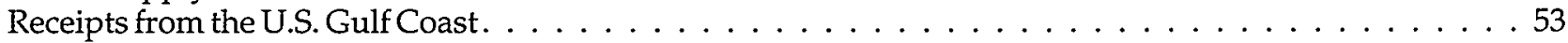

Supplies from Area Refineries . . . . . . . . . . . . . . . . . . . . . . . 54

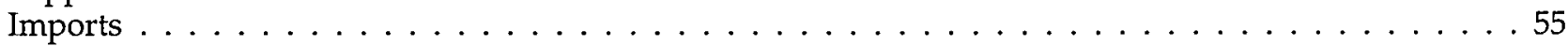

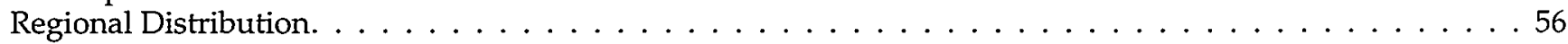

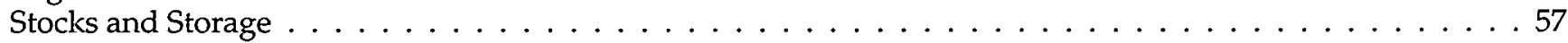

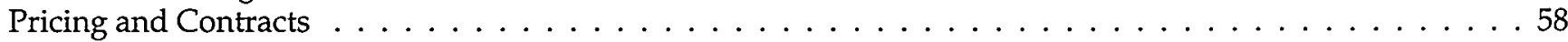

Market Implications of Reducing Reliance on Distillate. . . . . . . . . . . . . . . . . . . . . 59

6. Policy Initiatives for the Northeast Heating Fuels Market. . . . . . . . . . . . . . . . . . 61

Basis for a Policy Mix . . . . . . . . . . . . . . . . . . . . . . . . 62

Policies for Immediate Assistance . . . . . . . . . . . . . . . . . . . . . . . . . . 62

Actions To Help with Near-Term Problems . . . . . . . . . . . . . . . . . . . . . . . . 62

Policies To Add to the Diversity and Reliability of Energy Supply in the Northeast . . . . . . . . . . . . 64

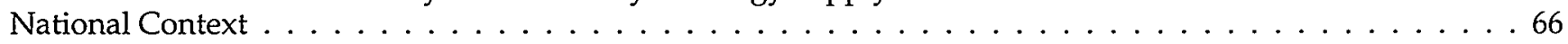

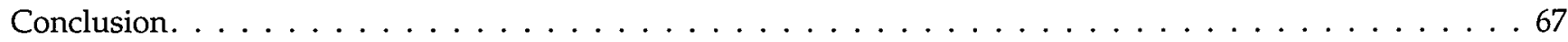

\section{Appendixes}

A. Request for Analysis. . . . . . . . . . . . . . . . . . . . . . . . . . . . . . . . . 69

B. Historical Data on Fuel Consumption and Prices for the Residential Sector in the Northeast Region . . . . . . 73

C. Historical Distillate Price Spikes: December 1989-January 1990, January-February 1994,

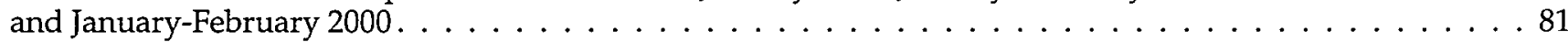

D. Electricity Generation and Fuel Consumption Data, $1980-1999$. . . . . . . . . . . . . . . . . . 87

\section{Tables}

ES1. Estimated Distillate Fuel Oil Switching and Conversion Potential in the Northeast by Sector . . . . . . . . . . xi

1. U.S. Distillate Fuel Oil Balance . . . . . . . . . . . . . . . . . . . . . . . . . 13

2. Residential Home Heating Case Illustration . . . . . . . . . . . . . . . . . . . . . . . . 19

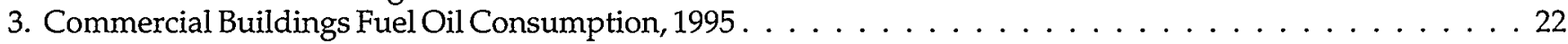

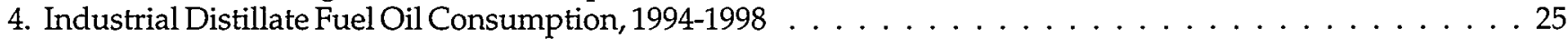

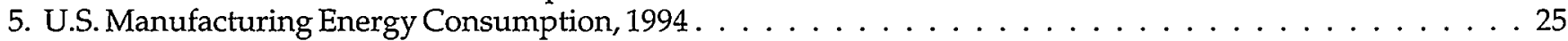

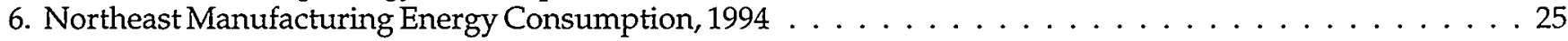

7. Northeast Estimated Switchable and Conversion Potential . . . . . . . . . . . . . . . . . . . . . . 34

8. Gas Storage Capacity and Deliverability in the Northeast, $1998 \ldots \ldots \ldots$. . . . . . . . . . . 41

9. Average Daily Consumption of Natural Gas in the Peak Month Before and After Switching from

Distillate to Natural Gas in the Northeast. . . . . . . . . . . . . . . . . . . . . . 45

10. Projected Pipeline Capacity Requirements Entering the Northeast Region If Large-Volume

Distillate Consumers Switch to Natural Gas . . . . . . . . . . . . . . . . . . 46 
11. Proposed Pipeline and Capacity Expansion Projects into the Middle Atlantic Region . . . . . . . . . . . 47

12. Distillate Fuel Imports to New England Originating In Venezuela, 1998-2000 . . . . . . . . . . . . . . . 55

13. Pricing Programs Offered to Consumers by Heating Oil Retailers in Northeast States, 1999 . . . . . . . . . 58

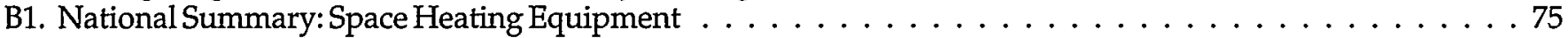

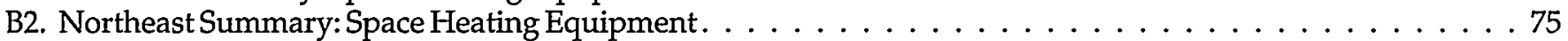

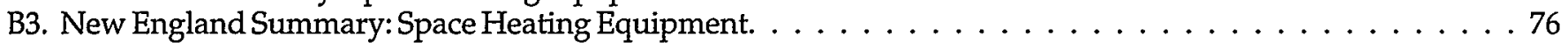

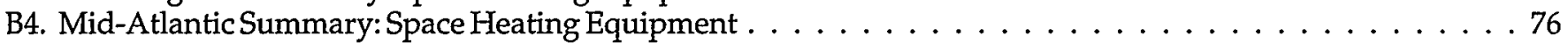

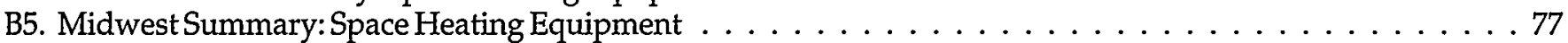

B6. Regional Fuel Consumption for Residential Space Heating. . . . . . . . . . . . . . . . . . . 77

B7. Regional Fuel Expenditures for Residential Space Heating . . . . . . . . . . . . . . . . . . 78

B8. Regional Fuel Prices . . . . . . . . . . . . . . . . . . . . . . . 78

B9. Regional Fuel Consumption for Residential Space Heating If All Households With Oil Heat

and Gas Service Switched to Gas Heat. . . . . . . . . . . . . . . . . . . . . 79

B10. Regional Fuel Expenditures for Residential Space Heating If All Households With Oil Heat

and Gas Service Switched to Gas Heat. . . . . . . . . . . . . . . . . . . . . . . 79

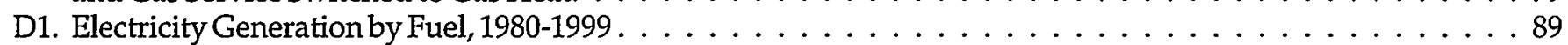

D2. Nonutility Diesel, Distillate Fuel Oil, and Residual Fuel Oil Consumption, 1991-1998 . . . . . . . . . . . . 90

D3. Distillate Fuel Oil Consumption for Electricity Generation by Month, 1980-1999 . . . . . . . . . . . . . . . 91

D4. Electricity Generation by Fuel, Census Division 1,1980-1999 . . . . . . . . . . . . . . . . . . 92

D5. Electricity Generation by Fuel, Census Division 2,1980-1999 . . . . . . . . . . . . . . . . . . . 93

D6. Electricity Generation by Fuel, Census Division 3,1980-1999 . . . . . . . . . . . . . . . . . . . 94

\section{Figures}

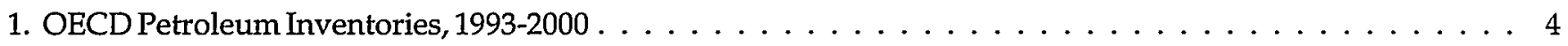

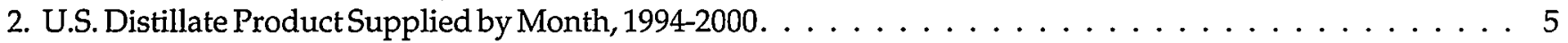

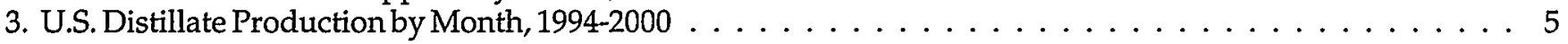

4. Stocks of High-Sulfur Distillate Fuel Oil (Heating Oil) in New England (PADD 1a), 1994-2000 . . . . . . . . 6

5. Stocks of High-Sulfur Distillate Fuel Oil (Heating Oil) in the Central Atlantic (PADD 1b), 1994-2000 . . . . . 6

6. Spot Prices for Heating Oil and Natural Gas, August 1999 -March 2000 . . . . . . . . . . . . . . . . . 8

7. Natural Gas Pipeline Capacity Feeding into the Northeast, with Mileage from Major Supply Sources

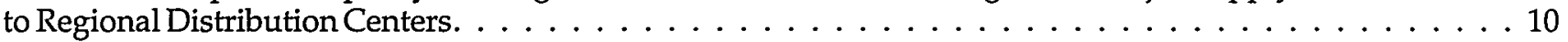

8. Natural Gas Storage Sites in the Northeast . . . . . . . . . . . . . . . . . . . . . . 11

9. Retail Residential Heating Oil Prices, Winter $1999 / 2000 \ldots \ldots \ldots \ldots \ldots$

10. Retail On-Highway Diesel Prices, Winter $1999 / 2000 \ldots \ldots \ldots \ldots \ldots \ldots$. . . . . . . . . . . 11

11. U.S. Distillate Fuel Oil Consumption, $1980-2005 \ldots \ldots \ldots \ldots$. . . . . . . . . . . . . . . . . 15

12. U.S. Distillate Fuel Oil Consumption, Excluding Transportation, $1980-2005$. . . . . . . . . . . . . 16

13. Northeast Consumption of Distillate Fuel Oil, Excluding Transportation, 1980-2005 . . . . . . . . . . . 16

14. Distillate Fuel Oil Use in the Residential Sector, $1980-2005 \ldots \ldots$. . . . . . . . . . . . . . . . . 17

15. Residential Heating Fuel Shares in the Northeast Census Region, 1980 and 1997 . . . . . . . . . . . . 17

16. Residential Fuel Prices in the Northeast Census Region, 1980-2005 . . . . . . . . . . . . . . 17

17. Commercial Delivered Energy Consumption in the Northeast Census Region by Fuel, 1997 . . . . . . . . 20

18. Distillate Fuel Oil Share of Commercial Fuel Use, $1980-2005 \ldots \ldots \ldots \ldots$

19. Commercial Sector Distillate Fuel Oil Consumption in the Northeast by End Use, 1995 . . . . . . . . . . . . 21

20. Natural Gas and Distillate Fuel Oil Use in Commercial Buildings in the Northeast and Maximum Fuel-Switching Potential, 1995 . . . . . . . . . . . . . . . . . . . . . 22

21. Ratio of Distillate Fuel Oil Price to Natural Gas Price in the Northeast Commercial Sector, 1980-2005 . . . . . 23

22. Projected Distillate Fuel Oil Use in the Northeast Commercial Sector:

Percent Change from Reference Case in Low and High World Oil Price Cases, 1999-2005 . . . . . . . . . 23

23. Total and Industrial Distillate Fuel Oil Consumption in the United States, 1980-2005 . . . . . . . . . . . 24

24. Distillate Fuel Oil Share of Industrial Delivered Energy Consumption in the United States

and the Northeast, 1980-1997. . . . . . . . . . . . . . . . . . . . . . . . . . . . 24

25. Potential Switching Capability from Distillate Fuel Oil Use in the Northeast Manufacturing Segment, 1994 . . 26

26. Maximum Potential for Industrial Sector Switching From Distillate Fuel Oil Use in the Northeast and Projected Switching Under High World Oil Price Assumptions, 2000-2005 . . . . . . . . . . . 27

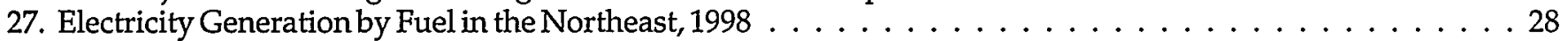

28. U.S. Electricity Generation by Fuel, $1950-2005 \ldots \ldots \ldots$. . . . . . . . . . . . . . . . . . . . . . . . 29 
29. Electricity Generation from Oil and from All Other Fuels by Census Division, 1998 . . . . . . . . . . . . . 30

30. Utility and Nonutility Generator Oil Consumption by Census Division, 1998 . . . . . . . . . . . . . . 30

31. Electric Utility Generation from Distillate Fuel Oil by Census Division and Month, 1989 . . . . . . . . . . . 31

32. Projected Oil Shares of Electricity Generation in the Northeast, 2000-2005 . . . . . . . . . . . . . . 32

33. Electric Utility Consumption of Distillate Fuel Oil, Residual Fuel Oil, and Natural Gas

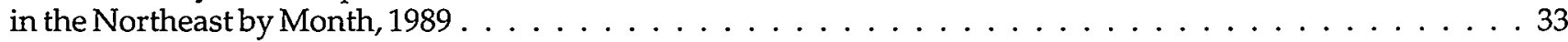

34. Average Monthly Natural Gas Consumption in the Northeast by Sector, 1989-1998 . . . . . . . . . . . . . 37

35. U.S. Pipeline Development Projects Completed in 1999 . . . . . . . . . . . . . . . . . . . . . 39

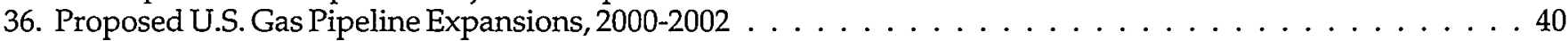

37. Average Costs for New Pipeline Capacity in the Northeast, $1996-2000$. . . . . . . . . . . . . . . . . 46

38. Regional Daily Deliverability from Underground and Liquefied Natural Gas Storage in the Northeast, 1998. . 48

39. Northeast Distillate Fuel Oil Supply Sources . . . . . . . . . . . . . . . . . . . . . . . . 52

40. Distillate Fuel Oil Supply on the East Coast by Source, $1995-1999 \ldots \ldots \ldots$. . . . . . . . . . . . . 53

41. Average Monthly Distillate Fuel Oil Supply on the East Coast by Source, 1995-1999 . . . . . . . . . . . . . 54

42. Distillate Fuel Oil Supplied to the East Coast from the U.S. Gulf Coast by Mode of Transport, 1995-1999 . . . 54

43. Quarterly Imports of Low-Sulfur and High-Sulfur Distillate Fuel Oil into the Northeast Region, 1995-1999. . . 56

C1. New York Harbor No. 2 Heating Oil Spot Prices Minus West Texas Intermediate Crude Oil Spot Prices,

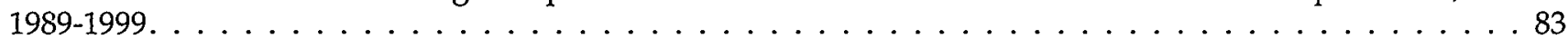

C2. Winter 1989-1990 East Coast Stock Variations from Average and Distillate Spreads . . . . . . . . . . . . . . 84

C3. Winter 1993-1994 East Coast Stock Variations from Average and Distillate Spreads . . . . . . . . . . . . . . . 85

C4. Winter 1999-2000 East Coast Stock Variations from Average and Distillate Spreads . . . . . . . . . . . . . 85 


\section{Executive Summary}

In January 2000, prices for heating oil, the oil consumers use to heat their homes, increased dramatically in the Northeastern United States. As a result, many consumers were faced with unexpectedly high heating bills as the weather turned colder. The level and duration of the price increase prompted the President to ask Secretary of Energy Bill Richardson to examine opportunities for converting factories and major users from oil to other fuels, which will help to free up future oil supplies for use in heating homes.

In response to the President's request, this study examines how the distillate fuel oil market (and related energy markets) in the Northeast behaved in the winter of 1999-2000, explains the role played by residential, commercial, industrial, and electricity generation sector consumers in distillate fuel oil markets and describes how that role is influenced by the structure of the energy markets in the Northeast. In addition, this report explores the potential for nonresidential users to move away from distillate fuel oil and how this might impact future prices, and discusses conversion of distillate fuel oil users to other fuels over the next 5 years. Because the President's and Secretary's request focused on converting factories and other large-volume users of mostly high-sulfur distillate fuel oil to other fuels, ${ }^{1}$ transportation sector use of low-sulfur distillate fuel oil is not examined here.

Fuel switching and conversion from distillate fuel oil to a different fuel can occur in either of two ways, depending on the time frame available. In the short term, existing equipment that has dual-fuel (e.g., distillate and natural gas) switching capability can be used. In the longer term, other equipment may be amenable to retrofits or replacements. ${ }^{2}$

\section{The Distillate Fuel Oil Market in the Winter of 1999-2000}

In mid-January 2000, prices for distillate fuel oil ${ }^{3}$ and natural gas rose dramatically in the Northeast. For example, between January 14 and February 4, 2000, New York Harbor spot prices for home heating oil (generally, high-sulfur Number 2 distillate fuel oil) rose from $\$ 0.76$ to $\$ 1.77$ per gallon, a 133-percent increase. Over a similar period, from January 11 to January 21, 2000, the New York spot prices for natural gas rose from $\$ 2.65$ to $\$ 11.75$ per million Btu, an increase of more than 340 percent. Retail prices for distillate fuel oil-the prices faced by consumers-rose less dramatically but still showed strong increases. For example, between January 17 and February 7,2000 , the average price of home heating oil for residential customers in New England rose from $\$ 1.18$ to $\$ 1.96$ per gallon, a 66 -percent increase. For the typical household with a 275-gallon tank that was filled up at the peak price, the increase amounted to approximately $\$ 140$ for an average fill-up (two-thirds of a tank). During the same period, the New England retail price of diesel fuel (low-sulfur distillate used for transportation) rose from $\$ 1.44$ to $\$ 2.12$ per gallon, a 47 -percent increase. ${ }^{4}$ In February, the return to warmer weather and the arrival of new distillate supplies, mainly in the form of imports, relieved the market imbalance and prices fell.

In the markets for distillate fuel oil, as in all competitive markets, the balancing of supply and demand sets prices. Any factor that leads to a significant imbalance-insufficient supply to meet demand or, vice versa, supply that exceeds demand-can cause sharp price changes. The key factors that influence prices in distillate fuel oil markets include supply and demand in

\footnotetext{
${ }^{1}$ In New Jersey, environmental regulations limit consumption of high-sulfur distillate fuel oil by large-volume distillate users.

${ }^{2}$ Furnace tuneups, insulation, and other efficiency measures may also reduce distillate consumption; however, they are unlikely to have a significant impact and are not included in this study.

${ }^{3}$ Throughout this report, the term "home heating oil" is used to indicate Number 2 high-sulfur distillate fuel oil. There are exceptions to this definition which, for the sake of improved communication to a broader audience, are often simplified-for example, Number 1 distillate oil and low-sulfur Number 2 distillate can also be easily used for home heating if necessary and available. Price usually precludes their use for heating.

${ }^{4}$ Diesel fuel oil and home heating oil are both distillate fuel oils. The primary difference is that on-road diesel fuel has a lower maximum sulfur content and is subject to Federal and State motor fuels taxes. Diesel has slightly higher cost, excluding taxes, than high-sulfur distillate or home heating oil.
} 
the world crude oil market, supply and demand in the markets for competing fuels (such as natural gas), the status of distillate fuel oil refining and delivery capacity, the level of stocks held by wholesalers and retailers, and weather-induced fluctuations in demand. The last factor, weather, is especially important in the market for home heating oil, because its chief uses are for heating homes in the Northeast and meeting the marginal fuel requirements of some industrial plants and power plants when demand is high and other fuels are not available.

Sharp movements in any combination of the factors mentioned above can cause, and historically have caused, significant swings in distillate fuel oil prices. In the winter of 1999-2000, several factors appear to have played key roles in the price increases seen in the Northeast: rapidly rising world oil prices, lower than normal inventories of distillate fuel oil, adverse weather conditions, constraints on natural gas pipeline capacity in some areas of the Northeast, and delivery and production problems for distillate fuel oil. These factors taken together led to the sharp increases in distillate fuel oil and natural gas prices seen in the Northeast in mid-January 2000.

When the colder weather hit in January, consumers increased their demand for both home heating oil and natural gas, and prices rose. Because distillate fuel oil stocks were below normal levels, quickly available supplies were limited and prices responded sharply to the increase in demand. At the same time, the demand for natural gas in the region stretched the capacity of some pipelines, and natural gas customers on interruptible contracts, mainly distillate-switchable large industrial and power plants, ${ }^{5}$ were asked to switch to their alternative fuel--primarily, distillate fuel oil. When customers seeking to avoid high natural gas prices and interruptible natural gas customers entered the distillate fuel oil market, the upward pressure on distillate oil prices increased still further.

Coming into the winter of $1999-2000$, world oil prices rose dramatically. After several years of low prices, the price of crude oil rose from approximately $\$ 12$ per barrel $^{6}$ in February 1999 to about $\$ 34$ per barrel in early March 2000-still much lower than the record high world oil price of $\$ 70$ per barrel (in 1999 dollars) seen in 1981. Members of the Organization of Petroleum
Exporting Countries (OPEC) and key non-OPEC countries, notably, Mexico and Norway, had reduced their production in response to the low crude oil prices in 1997 and 1998. The production decline, in combination with increased consumption in industrialized countries and Southeast Asia, led to an imbalance in world crude oil supply and demand: more was being consumed than produced. This, in turn, led to a drawdown of world crude oil inventories.

A related drawdown occurred in distillate fuel oil inventories. With crude oil prices rising faster than product prices in 1999, refiners saw their operating margins shrinking. In response, they reduced their purchases of expensive crude oil and their production of refined products, including distillate fuel oil. The production cutbacks contributed to a nationwide drawdown of distillate fuel oil inventories toward the end of 1999. Given the normal stocks and the relatively warm weather in early December, the drawdown in December was stronger than expected, particularly in the Northeast. ${ }^{7}$ For example, in New England stocks of high-sulfur distillate fuel oil fell by 35 percent, from 11.6 million barrels in early December to 7.5 million barrels in early January. Similarly, in the Central Atlantic, ${ }^{8}$ high-sulfur distillate fuel oil stocks fell by 24 percent, from 24.5 million barrels in early December to 18.6 million barrels in early February. Although heating oil inventories often decline in December, the magnitude of the stock draw was greater than expected from historic patterns.

When cold weather hit in January, low stocks could provide little supply, and prices reacted strongly. During the week of January 22,2000, temperatures in the New England and Middle Atlantic areas shifted from being 15 to 17 percent warmer than normal, respectively, to 24 and 22 percent colder than normal. The change increased weekly heating requirements by about 40 percent. As a result, the demand for distillate fuel oil increased in all segments of the market. Residential and commercial consumers increased their use of distillate fuel oil to heat their homes and businesses, power companies increased their use to meet the demand for electricity (in some cases by switching from natural gas), and industrial customers with dual-fired facilities increased their use of distillate fuel oil by switching from natural gas, either as required by their gas supply contracts or to avoid the higher price of natural gas. The problem of unexpected rapid increases in demand for

\footnotetext{
5 Interruptible contracts, as an industry practice, equate "quality of service with cut-off temperatures" - the lower the cutoff temperature, the higher the quality of service and the higher the transportation rate charged. When temperatures fall below specified cutoff temperatures, the gas transporter/marketer may provide notice of up to 24 hours, after which the customer is to stop consuming gas. Notice to cut off usage is not necessarily automatic.

${ }^{6}$ West Texas Intermediate spot oil price.

${ }^{7}$ The Northeast is defined as Maine, Vermont, New Hampshire, Connecticut, Rhode Island, New York, New Jersey and Pennsylvania. This conforms to Census region 1, composed of Census divisions 1 and 2 (New England and Middle Atlantic).

${ }^{8}$ The Central Atlantic, also known as Petroleum Administration for Defense District (PADD) 1b, consists of New York, Pennsylvania, New Jersey, Delaware, Maryland, and the District of Columbia.
} 
distillate fuel oil was aggravated by serious delivery problems. For example, Coast Guard ice breakers worked overtime to keep the Hudson River open during the coldest weather, and high winds and rough water in Long Island Sound made it too difficult for barges to unload heating oil from a waiting tanker in New Haven, Connecticut, in early February.

The pressure put on distillate fuel oil markets by the sudden change in weather was exacerbated by relatively high natural gas prices. In some uses like boilers or generators, natural gas and distillate fuel oil can be substitutes for one another. If the price of one rises relative to the other, some consumers-mostly large industrial facilities or power plants-will switch to the other fuel. In October 1999, wellhead and spot market prices for natural gas were 35 percent and 60 percent higher, respectively, than in October 1998. The increase was due in part to higher prices for competing fuels and in part to expectations of higher natural gas consumption if normal weather patterns developed.

When the weather turned colder in the Northeast in late December 1999, natural gas spot prices for delivery to the New York citygate rose substantially. Early in December natural gas prices were generally below $\$ 3.00$ per million Btu, but on December 21 they rose to $\$ 4.11$, and they stayed between $\$ 3.55$ and $\$ 4.87$ per million Btu through December 29. New York citygate prices fell substantially in early January 2000 , before rising to $\$ 6.34$ per million Btu on January 18. Gas traded above $\$ 6.00$ per million Btu on a majority of the days between January 13 and February 13. Gas pipeline capacity into the Northeast was heavily utilized during the period. Several pipeline companies indicated that they had reached new peak levels for service; representatives of one company, Transco, testified that they had no interruptible capacity available on their system from October 20 to the date of the testimony, February 24, 2000.

In general, the ability to bring natural gas into the Northeast is more limited than in other areas of the country. The region receives the majority of its natural gas supplies through a single supply corridor from the Southwest through Pennsylvania and New Jersey. In addition, the Northeast markets are separated from major natural gas supply areas in the U.S. Southwest and western Canada by substantial distances.

Although New York citygate natural gas prices and New York Harbor distillate fuel oil prices are about equally volatile, retail natural gas prices to residential customers appear to be less volatile than retail heating oil prices. For residential natural gas customers, the distribution charges added by local distribution companies (about $\$ 4.00$ per million Btu) mute the effects of citygate price volatility. Further, the purchasing and billing practices of natural gas distribution companies also can obscure short-term price fluctuations.

To address the surge in heating fuel prices, the Federal Government responded with release of funds from the Low Income Home Energy Assistance Program (LIHEAP), to relieve some of the financial burden to low-income households. The surge in distillate home heating oil prices subsided four weeks after it started.

\section{Distillate Fuel Oil Consumption}

Among customer types in the Northeast, residential consumers are by far the largest users of distillate fuel oil, ${ }^{9}$ excluding transportation use. In 1997 they accounted for more than two-thirds (68 percent) of the distillate fuel consumption in the region. The entire buildings sector-residential plus commercial users-accounted for more than 90 percent of total distillate fuel oil consumption in the region. Industrial firms and power plants accounted for smaller shares, 8 percent and 2 percent, respectively, on an annual basis. However, while small on an annual basis, the role played by industrial users and power plants can vary significantly during the course of a year.

In the residential sector, distillate fuel oil is mostly used for home heating, primarily in the Northeast. Nationwide, distillate fuel oil accounted for only 8 percent of the energy delivered to the residential sector in 1997, but 73 percent of that consumption occurred in the Northeast. Homes in the Northeast rely on home heating oil for heating because heating oil prices compare favorably to other heating fuels in the region. Even with the occasional surge in heating oil prices, historically, heating with distillate fuel oil in the Northeast has been less expensive than heating with natural gas. An illustrative example, using actual household heating bills, estimated that a house on Long Island saved $\$ 1,800$ in fuel costs (in real 1999 dollars) over the past 20 years by continuing to use heating oil rather than switching to natural gas for heating. Although natural gas heating systems tend to be slightly more efficient than comparable oil heating systems, the study assumed for simplicity of presentation that their efficiencies were equal. In that sense, the analysis overestimates the fuel savings that resulted from staying on heating oil. On the other hand, the savings are even larger when the cost of the new gas furnace needed to switch fuels is included.

Over the past 20 years, residential use of distillate fuel oil in the Northeast has declined by 20 percent, and the number of customers using it has declined by 10 percent. Efficiency gains in building shells and furnaces, combined with warmer winters, have contributed to the decline. In addition, the construction of new gas

\footnotetext{
${ }^{9}$ The consumers are residential, commercial, industrial, and electricity generators.
} 
pipelines into the region has given more consumers the choice between distillate fuel oil and natural gas. Since 1993, however, distillate fuel oil prices have been relatively low, allowing it to maintain a 30-percent share of the heating market in new homes in the region. Projections from the Annual Energy Outlook 2000 (AEO2000) show this trend continuing over the next 5 years.

Although generally small in comparison with residential use, distillate fuel oil use in other sectors in the Northeast can have a significant impact on prices, especially when demand is strong and supplies are tight. As in the residential sector, distillate fuel oil use in the commercial sector has declined over the past 20 years, and its use is expected to continue to decline over the next 5 years. In the commercial sector, distillate fuel oil consumption declined from 18 percent of total commercial energy use in the Northeast in 1980 to 12 percent in 1997. Typically, distillate fuel oil is used in the commercial sector for heating, water heating, cooking, and electricity generation. Using 1995 data for buildings whose owners reported that they could switch heating fuels without any new equipment purchases or retrofits, it is estimated that just under a quarter (52 trillion Btu or about 9 million barrels) of the distillate fuel oil used in the commercial sector in the Northeast could be switched to other fuels, such as natural gas.

In the industrial sector, distillate fuel oil is a relatively minor fuel, accounting for only 4 percent of total U.S. industrial fuel consumption in 1997. In the Northeast, the 79 trillion Btu (about 13.5 million barrels) of industrial distillate fuel oil consumption in 1997 accounted for only 3 percent of total industrial fuel consumption. The consumption of distillate fuel oil in the industrial sector in the Northeast is divided nearly equally between manufacturing and nonmanufacturing uses. In the nonmanufacturing segment, where distillate fuel oil is used primarily for on-site transportation (moving things around the plant and farm sites), it is unlikely that a significant portion of it could be easily switched to another fuel. Within the manufacturing segment in the Northeast the key uses of distillate are as a boiler fuel (37 percent), as a process fuel ( 32 percent), for heating and ventilation (12 percent), and for on-site transportation (9.8 percent). Using 1994 data, $^{10}$ it is estimated that approximately 24 percent ( 9 trillion Btu or about $1.6 \mathrm{mil}-$ lion barrels) of the distillate fuel oil used in the Northeast manufacturing segment could be switched quickly to other fuels without equipment purchases or retrofits. Over the next 5 years, distillate fuel use in the Northeast industrial sector is expected to increase by just over
1 percent annually, but the rate could vary depending on oil prices.

Oil plays a small role in the electricity generation sector, and generation from distillate fuel oil is a very small portion of that. In 1998, oil accounted for less than 3.4 percent of total U.S. electricity generation, and generation from distillate fuel oil accounted for only 0.4 percent of total generation. Overall, the share of generation from oil has been declining for some time, as natural gas has become more available and the efficiency of new natural gas generating technologies has continued to improve. This trend is expected to continue over the next 5 years. Even in the early 1980s, when oil-fired generation was more important, the share from distillate fuel oil never exceeded 1 percent. The vast majority of the oil used for electricity generation is residual fuel oil.

In the Northeast the power generation sector is more dependent on oil than in other parts of the country. For example, in New England 24 percent of generation comes from oil. Even in these more oil-dependent regions, however, distillate fuel oil plays a small roleonly 6 percent of total oil generation. Distillate fuel oil is typically used in small amounts in steam plants for flame control and in relatively inefficient combustion turbines and internal combustion engines when the demand for electricity is high and other fuels are unavailable to generate electricity. If all the distillate fuel oil use in the power generation sector in the Northeast were switched to another fuel-most likely, natural gas-it would amount to about 35 trillion Btu (6.1 million barrels) of distillate fuel oil. Under more severe weather conditions, as experienced in December 1989, the annual consumption could rise to as much as 41 trillion Btu (7.1 million barrels). It is unreasonable to assume, however, that all of that fuel use could be quickly switched. Some of the plants that burn distillate fuel oil are not dual-fired and may not have easy access to natural gas.

In summary, on an annual basis, if all the distillate fuel oil used in the Northeast commercial, industrial, and electric power sectors that could conceivably switch (even with equipment purchases and retrofits) were replaced with another fuel, total distillate fuel oil use would be reduced by 33.6 million barrels. However, as discussed earlier, it is unlikely that all of this distillate fuel oil use could be switched to another fuel. Looking only at the quantity of consumption that is estimated to be reasonably switchable, ${ }^{11}$ the total that could be made available for residential use is only 13.1 million barrels.

\footnotetext{
1997).

${ }^{10}$ Energy Information Administration, Manufacturing Consumption of Energy 1994, DOE/EIA-0512(94) (Washington, DC, December

${ }^{11}$ Because distillate fuel oil consumption for electricity generation in periods other than the winter heating season does not adversely affect home heating oil prices, it is excluded from the "reasonably switchable" calculation.
} 
We believe this to be a high estimate of the distillate fuel switching potential in the Northeast. ${ }^{12}$ In addition, as is explained later, the reduction in nonresidential distillate fuel use may not lead to a permanent increase in supplies available for home heating, and the volatility in the market may not be reduced.

Because the use of distillate fuel oil varies significantly across the seasons, it is more important to look at the potential for reducing nonresidential sector use during the winter months, when the use of distillate fuel oil for heating is greatest and rapid price increases are most likely. Using historical information about the distribution of seasonal use of distillate fuel oil in the commercial, industrial, and electricity generation sectors, it is estimated that the volume of their winter season switchable distillate use could be as high as 133,000 barrels per day-about 11 percent of residential heating oil use in the winter (Table ES1).

Because the Northeast's residential sector is highly dependent on home heating oil, whose prices are normally highest in the winter, colder-than-normal winter weather will further increase the demand and prices for heating oil. If, in addition, heating oil resupply problems are coupled with additional distillate fuel oil demand of 100,000 to 133,000 barrels per day from interruptible and/or fuel-switchable customers, home heating oil prices could rise sharply, as they did in the winter of 1999-2000.

\section{Switching or Converting From Distillate Fuel Oil}

Homeowners can be given increased access to distillate fuel oil or, at least, protected from steep price runups in future winters. Actions that may help include: encouraging distillate fuel oil users outside the residential sector to use other fuels, particularly natural gas; improving the operation of the Northeast distillate fuel oil market (for example, with better planning tools, more local storage capacity at the wholesale, retail, and consumer levels, and/or better delivery channels); and providing more direct assistance to consumers. Each of these approaches has practical limits, however, and their costs would have to be borne by consumers and taxpayers.

\section{Natural Gas Market Effects}

Possible changes to natural gas use considered in this report include (1) keeping large consumers with "switchable" equipment (that can use either fuel) from moving to distillate fuel oil when gas prices are high; and (2) in combination with keeping switchable firms on natural gas, moving some of the "distillate-only" capacity ${ }^{13}$ to natural gas. In this analysis it is estimated that, over a 3-month winter period (contiguous December, January, and February), the maximum "averageday" switchable fuel consumption ${ }^{14}$ is equivalent to about 133,000 barrels of distillate fuel oil per day. No

Table ES1. Estimated Distillate Fuel Oil Switching and Conversion Potential in the Northeast by Sector

\begin{tabular}{|c|c|c|c|}
\hline Sector & $\begin{array}{l}\text { Maximum Annual } \\
\text { Switchable Volume } \\
\text { (Million Barrels) }\end{array}$ & $\begin{array}{l}\text { Daily Average Daily Switchable } \\
\text { Volumes in December-February } \\
\text { (Thousand Barrels per Day) }\end{array}$ & $\begin{array}{c}\text { Conversion Potential If All Distillate } \\
\text { Use by Large Users Were } \\
\text { Converted to a Different Fuel } \\
\text { (Million Barrels) }\end{array}$ \\
\hline Industrial $\ldots \ldots \ldots \ldots \ldots \ldots$ & 1.6 & 16 & 6.5 \\
\hline Electricity Generation $^{\mathrm{a}} \ldots \ldots \ldots$ & $2.9^{\mathrm{b}}$ & $31^{b}$ & 7.1 \\
\hline Total $\ldots \ldots \ldots \ldots \ldots \ldots \ldots$ & 13.1 & 133 & 33.6 \\
\hline
\end{tabular}

${ }^{\mathrm{a}}$ Because usually only one-third of distillate consumption for electricity generation occurs in the winter months (December, January, and February), the consumption shown is the estimated winter use portion, assuming that 40 percent of the year's distillate use might occur in the winter of an unusual year.

Winter only.

Source: Tables in Chapter 3 of this report.

\footnotetext{
${ }^{12}$ The methodology used to derive the maximum distillate fuel that is switchable in the short run intentionally overestimates the actual amount. Because actual consumption data for January and February 2000 are not available, the switchable amount was calculated by sector (commercial, industrial, and electric generation) from available data based on normal weather and adjusted to approximate the conditions of the winter of 1999-2000. Taken together, it is estimated that distillate consumption during an unusually cold 3-month winter period could be as much as 42 percent higher than consumption during a normal winter.

13 "Distillate-only" means that the equipment can only burn distillate fuel oil.

${ }^{14}$ Some establishments have separate gas and distillate (or residual fuel) boilers to serve the same energy needs, choosing the fuel and equipment to be operated on the basis of relative fuel costs.
} 
three-month winter period in the past 20 years has had average-day switchable distillate consumption that exceeded this average. On very cold winter days, however, switchable consumption may be higher for brief periods.

The conversion of distillate fuel oil consumers to natural gas by 2005 depends on the economics (end-use equipment and gas supply costs) and the effectiveness of their implementation. Because the ultimate effectiveness of policy initiatives cannot be known in advance, the estimates used in this report are sensitivities representing different sizes of the market that might be moved away from distillate fuel oil. A commitment to switch to natural gas usually means that the consumer will also have to commit to firm contracts for supply, transportation, and local delivery of the gas.

Conversion from distillate to natural gas would require a natural gas supply line and gas burners in existing distillate-burning equipment, such as boilers or turbines. Alternatively, installation of a new system that burns a different fuel may be considered when fuel price differences are expected to be large for some time (economic conversion) or when the original equipment fails and needs to be replaced or repaired. The rate of equipment failure is likely to be the primary factor affecting market opportunities for conversions from distillate fuel oil to other fuels.

The Northeast receives 71 percent of its current natural gas supply ${ }^{15}$ from net inflows from other U.S. regions, 24 percent from international imports, and 2 percent in the form of liquefied natural gas (LNG) imports. Less than 3 percent of the supply comes from production in the Northeast region, all of which occurs in the Mid-Atlantic Census division. New England is highly dependent on flows from other U.S. regions, obtaining 89 percent of its current supply from the domestic transportation network.

Natural gas flow from the Sable Island pipeline project began in the first week of January 2000 to serve parts of New England and Eastern Canada. The pipeline was first forced to shut down on January 7, 2000, due to hydrate formation in a subsea line (essentially, ice sludge blockage). ${ }^{16}$ The second shutdown occurred in mid-January, when the gas processing plant developed a gas leak and was again shut down for repair. ${ }^{17}$ Early gas flow reached about 110 million cubic feet per day, of which 36 million cubic feet per day entered U.S. markets. By early March, the gas flow was about 300 million cubic feet per day to markets in the United States. The Sable Island project is expected to reach flows of 450 million cubic feet per day by summer 2000, the majority of which is expected to serve U.S. markets.

Pipeline capacity entering the entire Northeast region was 12,519 million cubic feet per day at the beginning of 1999. If large-volume users with dual-fired capability switched from distillate to natural gas, 839 million cubic feet per day of additional pipeline capacity would be needed. By 2005, the additional new capacity required, relative to the beginning of 1999 , to provide gas service to the converted customers and to supply the baseline increase in gas use could reach 2,241 million cubic feet per day.

A number of recently completed pipeline expansion projects (including the completed expansion from Canada's Sable Island gas fields to New England), as well as the proposed Millennium, Independence, and associated projects, are intended to meet the growing demand for natural gas in the Middle Atlantic and New England regions. Although the demand for natural gas in the Northeast is expected to grow, all pipeline construction projects must satisfy a number of State, environmental, and regulatory requirements and gain public acceptance before they are approved and considered certain. Consequently, the fate of any proposed project remains uncertain until final approval is received. The current proposals alone represent about 2 billion cubic feet per day of potential additional capacity, well in excess of the additional capacity that would be needed on a peak day ( 839 million cubic feet per day) to address the new gas demand resulting from switching out of distillate, and nearly enough for the additional 2005 potential requirements, including the baseline projected growth in natural gas consumption. The Sable Island gas supply project (about 400 million cubic feet per day to New England) also appears to be more than adequate to handle the additional capacity ( 340 million cubic feet per day) needed to address New England's portion of the new switching to gas, leaving the need for an additional 506 million cubic feet per day to support the potential conversions through 2005 (see Chapter 4 of this report).

Serving the switchable market with natural gas appears to be physically feasible by fall 2002 with projects already built or with construction of expansion projects planned for the Northeast; however, those projects were not intended to provide firm service to current interruptible customers. Because of the lack of sufficient commitments, the construction dates for proposed pipeline projects to the Northeast, such as Market Link, are uncertain. Even if the proposed projects are built, at least 250 million cubic feet per day of additional capacity would be necessary to also serve the new potential

\footnotetext{
${ }^{15}$ Current supply is the sum of production, imports, and net inflow from other domestic regions. It excludes storage withdrawals and production within the region.

${ }^{16}$ NGI's Daily Gas Price Index (January 18, 2000), p. 3.

${ }^{17}$ NGI's Daily Gas Price Index (March 9, 2000).
} 
conversion customers in 2005. Because the planned pipelines were sized and targeted for specific customers with specific operating requirements (e.g., pressures), the system may not be capable of serving all the additional requirements of the former distillate users and, therefore, could require even more additional capacity than estimated. One of the major hurdles that potential new Federal policies must overcome, however, appears to be economic. For industrial consumers and electricity generators with the capability to switch between natural gas and distillate fuel oil, firm year-round contracts for natural gas may not be economical in the Northeast. The New Jersey Board of Public Utilities findings on pipeline construction for interruptible customers are consistent with this study: ${ }^{18}$

\begin{abstract}
"To design and construct a gas distribution system to serve the interruptible customer class on a yearround basis would require significant investment and take years to install. Furthermore, on a cost of service basis, the resultant tariff rates would undoubtedly make it uneconomical for large customers to avail themselves of year-round service. Therefore, absent the current interruptible service offerings by natural gas utilities, larger customers would burn an alternate fuel continuously and further complicate the supply situation."
\end{abstract}

Through 2005, several potential obstacles or unintended consequences are possible if establishments with current dual-fuel switchable systems become firm natural gas customers. Because any capability to meet the new load will require pipeline and storage capacity expansion that is sufficient to meet the new peak, the costs of the incremental pipeline and storage capacity will have to be recovered from new customers, as is usually the current policy of the Federal Energy Regulatory Commission (FERC). Otherwise, costs to existing firm gas customers (usually residential and small commercial customers) will increase. Firm transportation capacity has proved to be too costly for fuel-switchable customers in the past.

When interruptible customers use the natural gas system, at least some of the resulting revenues are applied to reducing transportation costs for firm customers, including residential users, for whom the pipelines were originally justified and built. If interruptible natural gas customers became firm customers, unless uncommitted capacity were available for firm service, new capacity would have to be built. Their previous purchases of interruptible service would no longer benefit the firm customers on existing capacity by reducing their costs. Further, pipeline operators would be faced with more unused off-peak capacity to auction off, with a very limited base of seasonal users, thereby reducing the value of the interruptible capacity. Pipeline companies currently gain some revenues from the sale of interruptible capacity. There could be a considerable loss of efficiency in the operation of the gas market and the economy in general if switchable capacity were kept on natural gas all year round.

\section{Distillate Fuel Market Effects}

While the elimination of incremental distillate fuel oil demand from customers switching from natural gas at peak is likely to reduce the potential for distillate fuel oil price spikes in the short term because of the overcapacity created, it cannot eliminate their possibility in the longer term, and it could increase the volatility of natural gas prices. Successful conversion of large-volume customers from distillate to natural gas could also exacerbate the potential for distillate price spikes, because it would remove a stable base of heating oil consumption. The remaining distillate fuel oil market would be smaller, consisting of the portion of current customers with a stronger seasonal usage pattern. Thus, distillate fuel oil dealers and refineries would be inclined to reduce inventories given the smaller market, the relative swing between seasons could be larger, and inventory management could be more difficult and uncertain. As the stock cushion diminished, the distillate fuel oil market could become less prepared for sudden increases in demand or decreases in supply.

\section{Current Market Mechanisms}

Simple and relatively low-cost market mechanisms are already provided by distillate and natural gas distributors to soften price shocks created by weather. About 98 percent of the Northeast heating oil dealers participating in a voluntary survey offer a budget payment plan, ${ }^{19}$ as do all gas utilities. The budget plans estimate the annual heating bill and allow customers to pay 11 equal amounts plus a 12th payment that reconciles any discrepancy in collections. Other pricing mechanisms that can minimize the risk of price shocks include price caps and guaranteed pricing.

About 54 percent of the Northeast oil dealers responding to a voluntary survey indicated that they provide price cap programs on distillate fuel oil to residential customers for a small "insurance" premium, and 55 percent offer guaranteed pricing. For a small premium pergallon charge, dealers cap the maximum price they charge to residential customers. Others simply offer a fixed price per gallon charge for a 12-month period. These programs, for customers who had chosen them, would have lessened the financial pain of the 1999-2000 surge in winter distillate prices or completely insulated

\footnotetext{
${ }^{18}$ State of New Jersey, Board of Public Utilities, Board of Public Utilities Heating Oil Review (February 23, 2000), p. 6, web site www.state.nj.us/bpu/wwwroot/communication/Govrpt.PDF.

${ }^{19}$ Gray, Gray, \& Gray, Oilheat Survey 1999, web site www.graymail.com.
} 
the customers from it. The extent of participation in these payment programs is not known; however, the persistence of relatively low world oil prices for all but one of the past 8 years suggests that they may not have been widely used.

Some existing market mechanisms are already available to mitigate future heating oil price spikes, including: (1) for large-volume, distillate-natural gas switchable users, maintaining adequate distillate fuel oil backup at the start of the winter season to reduce the potential for large intrusions into the heating oil market during very cold periods; (2) for residential consumers who buy new oil-heated homes, installing a larger oil tank to reduce the number of required fill-ups during the peak period; (3) for residential heating oil customers, adopting any one of the fuel oil purchasing plans (budget plan, cap price, or fixed price) that will meet their preferences for avoiding risks; (4) for all residential heating oil consumers, adding additional conservation measures, buying more efficient heating systems when they need to be replaced, and, in some cases, switching to a different fuel. As recent reports in the press have indicated, some Northeast consumers have reacted to the recent price spike by switching to natural gas or by purchasing high-efficiency heating systems, or are seriously considering switching to a more predictable heating oil plan. As a result of recent hearings by the New Jersey Board of Public Utilities, the Board noted that it will reconsider reimposing the requirement that interruptible gas customers maintain adequate alternate fuel supplies: "Given the magnitude of the [distillate volumes] involved, it is unlikely that this would have a significant effect on the price of heating oil. It is, however, worth considering as part of a future, overall response plan." 20

Other market approaches that are available for the electricity generation market include the expansion of interregional transmission capability and the construction and expanded use of nuclear, coal and renewables generation. Besides switching to other fuels for generation, regional distillate fuel oil use could be reduced by increasing interregional electricity transmission capacity and/or building new capacity to displace existing capacity. Given the high cost and long lead times for building new transmission capacity, however, displacing intermittent use of distillate fuel oil by electricity generators may not be an economical choice.

New gas-fired plants can be brought on line in 1 to 2 years, and many are already planned. Other new capacity types-coal, wind, biomass, nuclear and solar-are much less economical than gas and normally take longer to bring on line. In addition, because wind and solar are not dispatchable, ${ }^{21}$ they probably are not good substitutes for plants that use distillate fuel oil. The industrial sector already uses the maximum available amounts of black liquor and residues for cogeneration applications. Other incremental cogeneration opportunities are small in the 2000-2005 time frame without substantial financial incentives. The situation in the residential and commercial sectors is similar.

\section{Policy Initiatives}

This assessment indicates that the problems in the Northeast heating fuels market during winter 2000 were the result of infrequent, short-term events that occurred in the context of the region's unique energy market and concurrent tight worldwide oil supplies. Given this assessment, it will take a broad range of policies to avoid reoccurrences of the problems. Based on the experience of the winter, these policies should provide immediate information and assistance; help with information, planning, and emergency supplies in the near term; and add to the diversity and reliability of energy supplies for the future.

Policies for Immediate Assistance: In an energy emergency, the Federal Government must be prepared to identify the sources of the problem, supply timely public information, and provide appropriate immediate assistance. The record of Federal Government reaction to the heating oil problems last winter was good but could have been better. In recognition of the need to be better prepared in the future, the following action has been taken:

- Create Office of Energy Emergencies to improve communication. On May 26, 2000, the Department of Energy created an Office of Energy Emergencies to help prepare for and coordinate responses to energy emergencies. The Office will organize workshops and preparedness exercises with State energy officials and industry partners to enhance communication and readiness for emergencies.

Actions to Help with Near-Term Problems: For the next few years, the majority of Northeast energy consumers-both businesses and individuals - will be using the energy capital and infrastructure now in place. To make the best use of existing capability, several near-term policy actions are proposed to help consumers and States get information, conduct planning, and obtain emergency resources. These include:

- Highlight seasonal information and forecasts for the Northeast energy market. In fall 2000, EIA and the National Association of State Energy Offices will highlight the winter fuels outlook for the Northeast in their fall conference.

\footnotetext{
${ }^{20}$ State of New Jersey, Board of Public Utilities, Board of Public Utilities Heating Oil Review (February 23, 2000), p. 6, web site www.state.nj.us/bpu/wwwroot/communication/Govrpt.PDF.

${ }^{21}$ An electricity generator is "dispatchable" if it can provide electricity on an as-needed basis. Solar and wind plants are intermittent generators and are therefore not dispatchable.
} 
- Encourage planning and preparation by all market participants. Industry, State, and Federal government are urged to inform consumers of all types about different forms of purchasing plans, the operation of energy markets, and the operation of assistance programs. A separate DOE study will identify actions that might be taken by gas customers with the option to switch fuels.

- Request continued funding for the Low Income Home Energy Assistance Program and expanded funding for the Weatherization Assistance Program. The Administration has requested additional funds for both of these programs.

- Develop a Northeast Home Heating Oil Reserve. The President has proposed the creation of an environmentally sound home heating oil reserve in the Northeast and requested that Congress pass legislation detailing the specific aspects of the program.

- Study the need for area port dredging. The Administration recommends that the U.S. Army Corps of Engineers be provided funding for an assessment of the benefits and costs of dredging and development of area ports for fuel shipments.

Policies to Add to Diversity and Reliability of Supply: Over a longer period of time a greater set of policy options are possible. These include increased delivery of heating oil and natural gas, greater local inventories, and new fuel options, as well as changes to energy demand by conversion of customers to new fuels or by employing more efficient equipment.

- Reduce delays in Federal Government processes related to decisions on natural gas pipeline and storage capacity. When the Federal Energy Regulatory Commission reviews an application for a certificate of public convenience and necessity authorizing construction or operation of a natural gas facility, it must complete an environmental impact statement or environmental assessment. A number of federal agencies are responsible for reviews under different statutes. To improve the timeliness of these reviews, DOE recommends that the Council on Environmental Quality and the National Economic Council create an initiative involving the resource agencies and the Commission to set guidelines for completing the processes required in the Commission's deliberative process.

- Support joint Federal/State studies of regional storage opportunities for natural gas. Almost no undeveloped natural gas storage capacity is now available in the Northeast area. Lined rock caverns store natural gas in a manner similar to salt cavern storage but can be located in areas, like the Northeast, where salt caverns or conventional underground reservoirs are not present. DOE will conduct a detailed independent technical review of the concept at specific sites to support Federal and State review of proposed projects.

- Study changes to the tax treatment for conversion/hookup costs. The Administration will study options that would make the taxable status of contributions in aid of construction comparable for all types of utilities as a means of increasing fuel choices.

- Facilitate increases in the Northeast's liquefied natural gas infrastructure and supplies. DOE will work closely with the U.S. Coast Guard to review the proposal to increase deliveries of liquefied natural gas to Boston.

- Develop and demonstrate alternative methods of energy backup for large natural gas users. DOE will help New England consumers and utilities explore opportunities for new distributed energy systems to provide backup energy or significantly reduce peak loads.

- Evaluate options for further reducing or converting heating oil services at selected Federal buildings in the Northeast. DOE will explore with Federal facilities in the Northeast whether recent changes in energy markets or energy technologies have resulted in additional life-cycle cost-effective opportunities to reduce oil use.

- Support consumer education and building improvement programs. DOE will work with builders and designers to make energy saving strategies and features widely available and will also work with energy service providers to make energy efficiency savings as widely available as possible.

National Context: The prospects for energy consumption and supply in the Northeast are part of a larger national concern about expanding energy supply. The Clinton Administration has supported a number of energy policy actions for clean, efficient development and use of energy. However, national actions to help natural gas fulfill its potential as a clean, reliable domestic fuel would be important for all regions of the United States.

- Review Interagency Work Group on Natural Gas. DOE and the National Economic Council are seriously reviewing a recommendation of the National Petroleum Council to establish an interagency work group to create a balanced, long-term approach for responsibly developing the Nation's natural gas resource base; driving research and technology development, and streamlining and updating Federal Government processes that affect gas development and transmission.

- Resume annual energy meetings between the United States and Canada. To improve understanding about natural gas market, regulatory, and trade issues, the Administration proposes that DOE and its Canadian counterparts, the National Energy Board of Canada and the Department of Natural Resources Canada, should resume regular annual meetings. 


\section{Introduction}

\section{Purpose}

This study was undertaken at the request of the U.S. Secretary of Energy, Bill Richardson. ${ }^{1}$ As stated by the President, "I've asked Secretary Richardson to conduct a 60-day study on converting factories and major users from oil to other fuels, which will help to free up future oil supplies for use in heating homes."2 The principal purpose of this study is to examine the feasibility and impacts of converting factories and major users of heating oil to different fuels, and to discuss other possible supply-related policy options that may mitigate future heating oil supply problems in the Northeast. ${ }^{3}$ This study examines how the market behaved in the winter of 1999-2000, identifies the key price and demographic factors that influence the market, compares the market behavior in 1999-2000 with that in previous winters, and discusses options that could encourage major users of distillate fuel oil to convert to other fuels. Given the oil price environment in the winter of 1999-2000, the options considered are those that could have a meaningful impact over the next 5 years.

Throughout this report, the terms "home heating fuel oil" and "heating oil" are used to indicate number 2 high-sulfur distillate fuel oil. There are exceptions to this which, for the sake of improved communication to a broader audience we often simplify-for example, number 1 distillate oil and low-sulfur number 2 distillate fuel can also be easily used for home heating if necessary and available. Price usually precludes their normal use for these purposes.

\section{Review of the Oil Market Situation}

Over the past 12 months, the average daily price of West Texas Intermediate crude oil in world markets ranged from $\$ 12$ per barrel to more than $\$ 34$ per barrel in early
March (before subsiding in recent weeks), as members of the Organization of Petroleum Exporting Countries (OPEC) and several other exporting countries cut production and world oil demand increased. Prices were influenced by the successful adherence to announced cutbacks in production by OPEC and key non-OPEC members, notably Mexico and Norway. Also influencing prices were strong growth in oil consumption in the industrialized countries (which accounted for 60 percent of the growth in demand in 1999) and rising demand in Southeast Asia as the economies there began to recover from the recession of 1997-1998.

Stocks were used to meet demand growth in many countries. At the end of March 2000, world stocks of crude oil and refined products were below average levels. In response, prices rose from about $\$ 12$ per barrel in mid-February 1999 and over \$34 per barrel in early March 2000 (although $\$ 34$ per barrel is still less than half the peak inflation-adjusted price of $\$ 70$ per barrel- $\$ 39$ per barrel in 1981 dollars-that occurred in 1981). Following the OPEC agreement on March 29, 2000, to raise production by 1.7 million barrels per day and earlier declarations by Mexico that it would raise its oil production, crude oil prices fell into the $\$ 25$ per barrel range in early April 2000 (see discussion in Chapter 2).

Low U.S. stocks of heating oil in January 2000 set the stage for a price spike in the Northeast. ${ }^{4}$ Low inventories (stocks) ${ }^{5}$ left little cushion to meet sudden increases in demand or decreases in supply without creating upward pressure on oil prices. The demand for distillate and diesel fuel ${ }^{6}$ in the Northeast increased in midJanuary 2000 in response to cold weather. Delivery problems, primarily affecting tanker ships and barges, ${ }^{7} \mathrm{com}-$ pounded the problem of low stocks in the region by delaying the refill of depleted stocks (inventories). As local supplies diminished, prices surged. New England home heating oil prices ${ }^{8}$ peaked in January at $\$ 1.96$ per

\footnotetext{
${ }^{1}$ See Appendix A for a copy of the letter requesting the study.

${ }^{2}$ The White House, Office of the Press Secretary, Press conference by the President, Feb. 16, 2000, web site www.pub.whitehouse.gov/ uri-res/I2R? urn:pdi://oma.eop.gov.us/2000/2/17/1.text.1 (Washington, DC, February 17, 2000).

${ }^{3}$ Readers should note that "heating oil" is "distillate fuel oil."

${ }^{4}$ For purposes of this study, the Northeast is defined as New England (Maine, Vermont, New Hampshire, Massachusetts, Rhode Island, and Connecticut) and the Mid-Atlantic Census division (New York, New Jersey, and Pennsylvania). Oil supply data are collected at a larger level of aggregation (New England, Mid-Atlantic, Maryland, Delaware, and Washington, DC). The discussions in each case refer to the Northeast and the reader should keep the distinction in mind.

"The terms "stocks" and "inventories" are used interchangeably in this report.

${ }^{6}$ Diesel fuel is low-sulfur distillate fuel oil used for truck and heavy freight transportation.

${ }^{7}$ Frozen waterways slowed the arrival and unloading of distillate fuel oil in New York and Boston harbors.

${ }^{8} \mathrm{Home} \mathrm{heating} \mathrm{oil} \mathrm{is} \mathrm{distillate} \mathrm{fuel} \mathrm{oil.}$
} 
gallon (again, this price is still lower than the U.S. average heating oil price in 1981 of about $\$ 2.45$ per gallon in 1999 dollars - \$1.29 in 1981 dollars). In response, in early February 2000, U.S. refineries began increasing their output of distillate, and marketers substantially increased their purchases of imported distillate fuel oil. It takes several weeks for refiners to increase production and deliver product to the Northeast, and by mid- to late February new distillate supplies began arriving and prices began to decrease.

Distillate fuel oil imports played a major part in controlling the stock decline and moderating distillate fuel oil prices after the first week of February. Distillate fuel oil imports jumped from 105,000 barrels per day during the week of February 4 to 528,000 barrels per day during the week of February 11 and averaged more than 550,000 barrels per day for the last three weeks of February.

The surge in home heating oil and diesel fuel prices, primarily in the Northeast United States, prompted the President's request for a review of policy options that might help reduce the volatility of these prices in the future. The Secretary asked the Energy Information Administration (EIA) and the U.S. Department of Energy's Office of Policy to conduct an analysis of the causes of the price increases and the potential for conversion of large-volume distillate fuel users to other fuels by 2005. The options considered in this report are: (1) increasing natural gas pipeline capacity for deliveries to the Northeast, (2) removing obstacles to conversions from distillate fuel oil, (3) improving the management of distillate fuel oil supplies, particularly by large industrial users and electricity generators, and (4) increasing on-site distillate fuel oil storage capacity. The framework and results of EIA's analysis are described in this report.

Chapter 2 describes what happened in the 1999-2000 winter season and what factors contributed to the rapid price runups for heating oil in the Northeast. Chapter 3 focuses on Northeast energy consumption, describing the historical fuel mix in the Northeast by sector and estimating the ability of the region's large distillate fuel oil consumers to switch to different fuels. The chapter also examines the economics of space heating equipment choices in the Northeast, typically distillate fuel oil or natural gas, and provides an illustrative example for such choices. The historical costs of heating Northeast homes using home heating oil (distillate) and natural gas are analyzed and compared with those in the Midwest region and the United States as a whole. The economics of future heating fuel choices are examined, based on fuel price projections through 2005 from EIA's Annual Energy Outlook 2000.9
Chapter 4 examines the current supply, infrastructure, and processing for natural gas and describes how the current business environment affects supply, contracting practices, seasonal pricing, and storage. The chapter ends by examining the feasibility, from the supply perspective, and implications of moving a portion of the distillate fuel oil demand by large energy users to an alternate fuel like natural gas. Chapter 5 examines the supply, infrastructure, and processing for distillate fuel and describes how a successful conversion of large distillate fuel oil users in the Northeast might affect the market for distillate fuel oil.

The following definitions are provided to facilitate the discussions that follow:

Distillate Fuel Oil: Nos. 1, 2, and 4 heating oils and diesel fuels. Most often subdivided (by EIA) into:

- High-sulfur distillate fuel oil (often called "heating oil" but has other uses, including off-highway transportation, agricultural, and industrial)

- Low-sulfur distillate fuel oil (often called "diesel fuel" or, more appropriately, "on-highway diesel fuel"). Although low-sulfur distillate can also be used for heating, and sometimes is, its higher price normally precludes its use as a heating fuel.

Technically, the high-sulfur and low-sulfur designations are based on product specifications, whereas the diesel and heating designations are based on use.

New England: Census Division 1 and Petroleum Administration for Defense District (PADD) 1a. Includes Maine, New Hampshire, Vermont, Massachusetts, Rhode Island, and Connecticut.

Middle Atlantic: Census Division 2. Includes New York, New Jersey, and Pennsylvania.

Lower Atlantic: PADD 1c. Includes Virginia, West Virginia, North Carolina, South Carolina, Georgia, and Florida.

Midwest: Census Region 2. Includes Ohio, Indiana, Illinois, Iowa, Michigan, Wisconsin, Minnesota, Missouri, Kansas, Nebraska, North Dakota, and South Dakota.

\section{Northeast: Census Divisions 1 and 2.}

Central Atlantic: PADD 1b. Includes New York, New Jersey, Pennsylvania, Delaware, Maryland, and the District of Columbia.

South Atlantic: Census Region 5. Includes Maryland, Delaware, District of Columbia, West Virginia, Virginia, North Carolina, South Carolina, Georgia, and Florida.

${ }^{9}$ Energy Information Administration, Annual Energy Outlook 2000, DOE/EIA-0383(2000) (Washington DC, December 1999). 


\section{What Happened to Heating Fuel Prices in the Winter of 1999-2000?}

\section{Introduction}

In mid-January 2000, a combination of adverse weather conditions, low heating oil inventories, natural gas capacity and delivery constraints in some areas of the Northeast, and distillate delivery and production problems created rapid price increases in the distillate fuel oil (heating oil and diesel fuel oil) ${ }^{10}$ and natural gas markets in the Northeast. When spot prices for distillate fuel oil in the Northeast surged, retail prices for heating oil and diesel fuel quickly rose in response. ${ }^{11}$ This is not the first time heating oil prices have spiked in the Northeast. There were similar spikes in December 1989 and to a lesser degree in January 1994 (see Appendix C).

Historically, distillate fuel oil prices have risen sharply only during the high-demand winter months. In each case, including the experience in January and February 2000 , cold weather increased demand unexpectedly and hindered the arrival of new supply, as frozen rivers and, in some cases, high winds slowed the docking and unloading of barges and tankers. Stocks (inventories) were drawn down rapidly because the demand for distillate ful oil exceeded new supply. Because space heating in the Northeast depends heavily on distillate fuel oil from imports and from the Gulf Coast, which can take weeks to arrive, resolution of market imbalances is not immediate. Distillate fuel oil stocks approached very low levels in January and February, and wholesale buyers, concerned about supply availability, rapidly bid up the price of the new supplies that did arrive, until warmer weather and increased new supply relieved the market imbalance and prices fell.

Distillate fuel oil and natural gas prices are both affected by cold weather. Both fuels are used for heating, and increases in demand for either fuel can cause prices to rise during the winter season. Furthermore, there is some interplay between the use of the two fuels. Some large industrial, commercial, and electric utility customers with dual-fuel burning capability use distillate fuel oil as an alternate or peaking fuel (see Chapter 5). Some customers who normally use natural gas switch to distillate fuel oil either because they have interruptible contracts that require them to stop using natural gas under certain terms or conditions (such as low temperatures) or because they find distillate fuel oil economically more attractive..$^{12}$ As a result, distillate fuel oil is an important peak-demand fuel in the Northeast for residential as well as the other end-use sectors.

\section{Distillate Market Factors Leading to the Price Spike}

One of the key factors setting the stage for the distillate price spike in January and February 2000 was the very low level of distillate stocks at the beginning of January. With little inventory to absorb sudden demand or supply changes, the chances for a distillate price spike increased with cold weather.

\section{Crude Oil and Product Stocks Declined in 1999}

The low distillate stock situation at the beginning of January 2000 began with events in the crude oil market. Crude prices have changed significantly over the past year, rising by more than $\$ 20$ per barrel ${ }^{13}$ ( 48 cents per gallon) from under \$12 per barrel in mid-February 1999 to peak at about $\$ 34$ per barrel in early March 2000 , before falling back to around $\$ 25$ per barrel in early April 2000. This price increase was the result of a shift in the world balance between production and demand. In 1998, world oil production exceeded demand, petroleum inventories rose to very high levels, and the price of crude oil collapsed (Figure 1). In response to the low price, OPEC and several other crude oil exporting countries began cutting production. At the same time,

\footnotetext{
${ }^{10}$ Distillate fuel oil is a general classification for one of the petroleum fractions produced from crude oil. It is used primarily for space heating, on- and off-highway diesel engine fuel, and electricity generation.

${ }^{11}$ Diesel fuel and home heating oil prices usually move together. They are essentially the same product, except for sulfur content. On-highway diesel fuel, by statutory mandate, has a lower sulfur content than heating oil. In some regions, it is more economical for refiners to distribute one product, and so low-sulfur diesel fuel is used for both on-highway uses, where it is required, and off-highway uses, where it is not. High-sulfur distillate (heating oil) cannot be used on-highway, and it is dyed to distinguish it. Furthermore, on-highway diesel fuel is taxed at both the Federal and State levels.

${ }^{12}$ Not all large customers with fuel-switching capability leave natural gas fuel to use distillate. Some power plants, especially in New England, that use natural gas as baseload or intermediate load fuel will switch to residual fuel oil when the economics are favorable.

${ }^{13}$ West Texas Intermediate (WTI) spot price.
} 


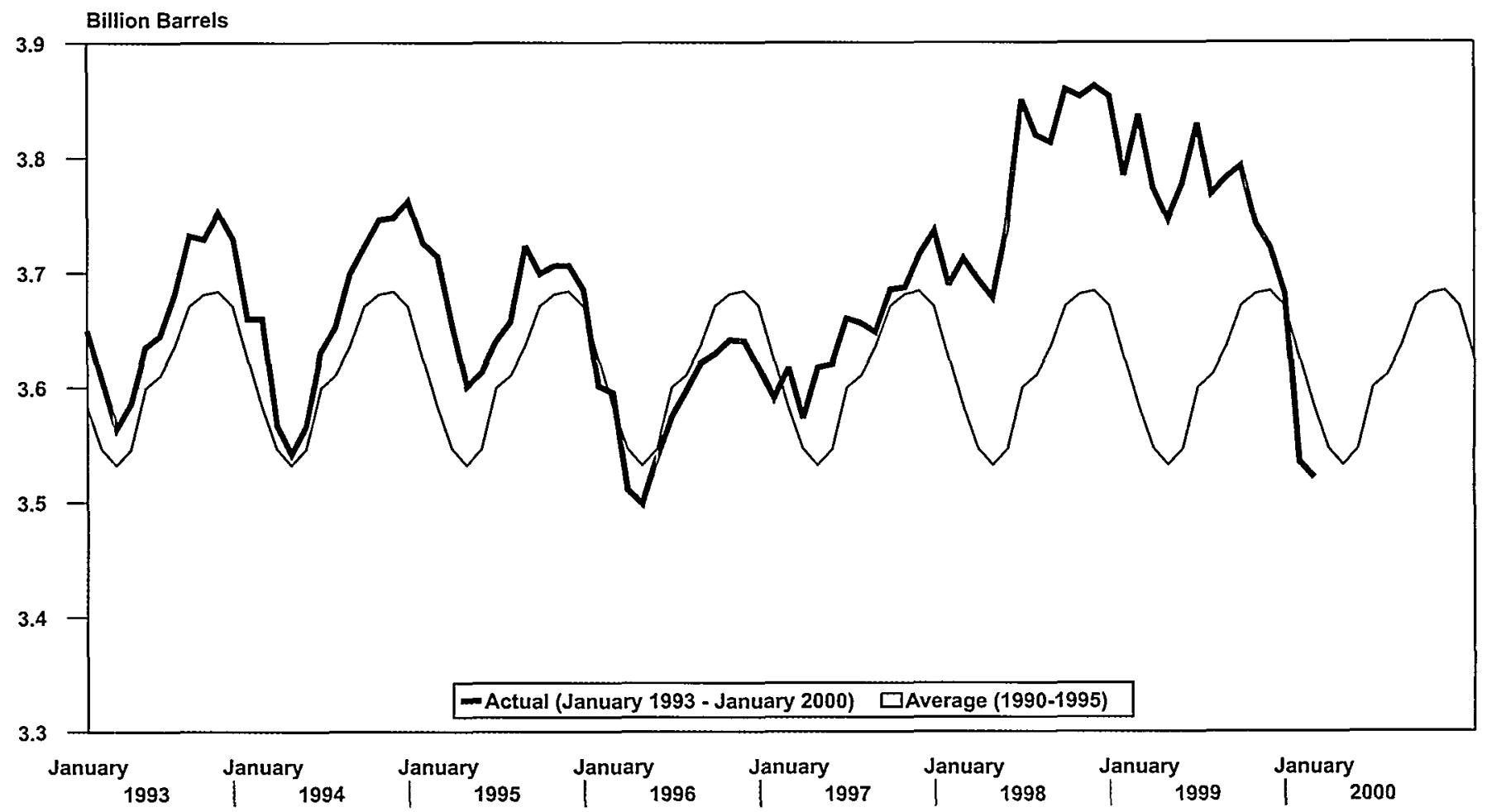

Note: OECD = Organization for Economic Cooperation and Development.

Source: Energy Information Administration, International Petroleum Monthly, DOE/EIA-0520 (Washington, DC, various issues), Table 1.5 .

Asian economies continued to recover from the recession of 1997-1998, and world demand grew fairly rapidly. The result was that world oil demand exceeded production and, consequently, crude oil and product inventories were used to meet the demand growth.

During 1999, crude oil prices rose faster than petroleum product prices, reducing refining margins. Higher crude oil prices and the squeeze on product margins encouraged refiners to constrain crude oil purchases, restrict refined product output, and draw down crude oil and product inventories. World crude oil and product inventory levels, which had been particularly high since 1998, sank to very low levels by December 1999. U.S. distillate stocks were no exception to this pattern of decline.

\section{U.S. Distillate Stocks Fell Below Normal in December 1999}

U.S. distillate fuel oil stocks began the heating season above the midpoint of the normal range, but they were not built as usual and ended November below the midpoint of the normal range. Demand for distillate fuel oil in December 1999 was high, despite warmer weather than normal: 10 percent warmer than normal nationally and 11 percent warmer in the Northeast (Figure 2).
Distillate stocks fell rapidly in December, in part because low refinery margins constrained refinery production to approximately the previous year's level (Figure 3), and imports were at an average level.

Stocks of high-sulfur distillate fuel (home heating oil) in the Northeast drove the U.S. distillate stock pattern. Northeast heating oil stocks ${ }^{14}$ were high throughout 1998 and most of 1999, the remnant of the warm 1998-1999 winter. Although the seasonal stock build did not follow the historical path, inventories were well above the recent historical levels in New England even into November, and in the Central Atlantic region ${ }^{15}$ they were still solidly in the normal range (Figures 4 and 5). However, heating oil stocks in New England fell by more than 35 percent, from 11.6 million barrels in early December to less than 7.5 million barrels in early January. Similarly, in the Central Atlantic region, heating oil stocks declined by 24 percent, from 24.4 million barrels in early December to 18.6 million barrels in early January. The pace of the drawdown through the rapid price increases merits highlighting, particularly in New England, where stocks fell from more than 11 million barrels in early December to less than 3 million barrels by early February. In the Central Atlantic the level of stocks was much higher and the pace of decline was not as

\footnotetext{
${ }^{14}$ The terms "stocks" and "inventories" are used interchangeably in this report.

${ }^{15}$ The Central Atlantic region is a petroleum supply region designation that includes New York, New Jersey, Pennsylvania, Delaware, Maryland, and Washington, DC. It is also known as Petroleum Administration for Defense District 1b (PADD 1b).
} 
Figure 2. U.S. Distillate Product Supplied by Month, 1994-2000

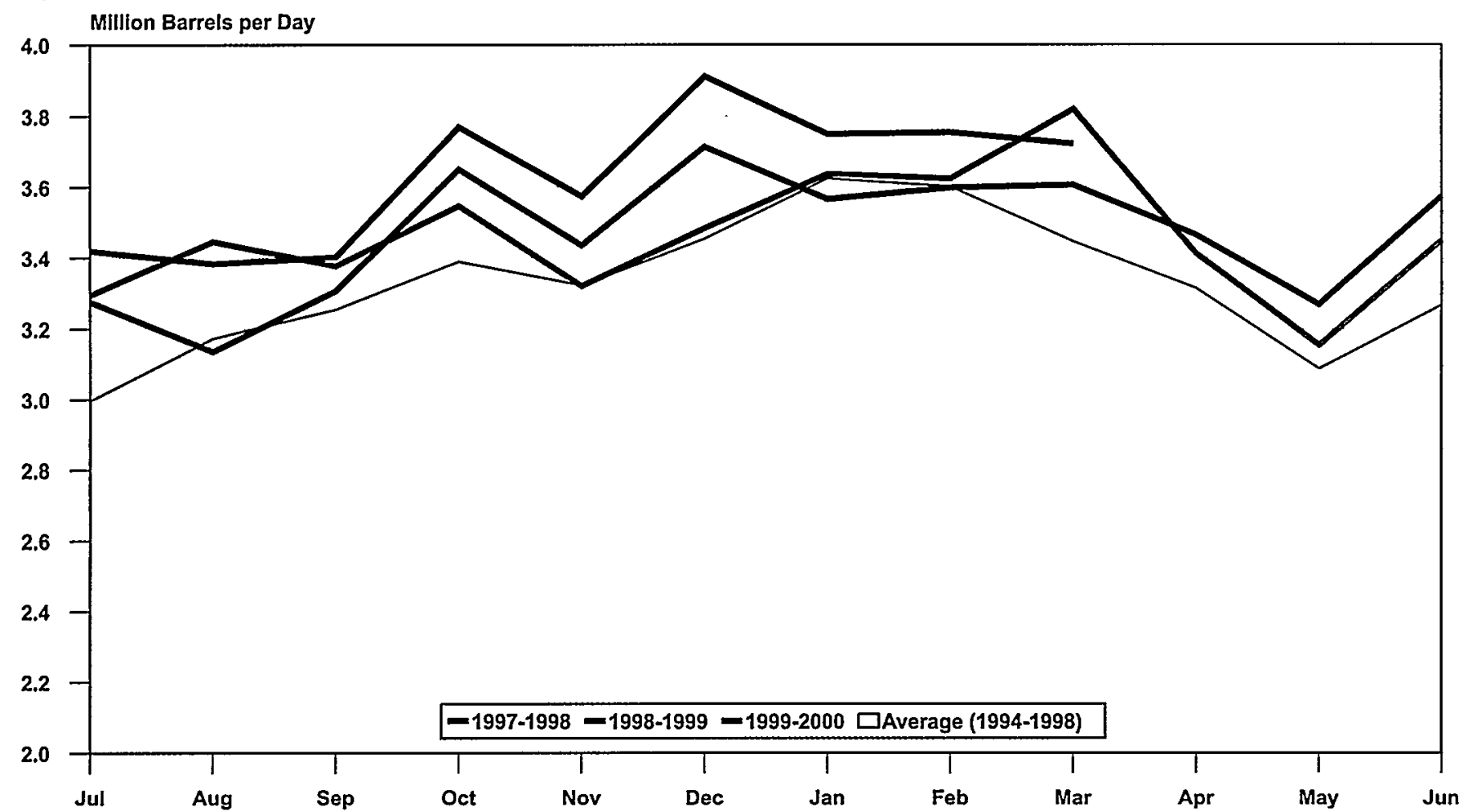

Note: The "Product Supplied" line in the graph provides a proxy measure of consumption.

Source: Energy Information Administration, Petroleum Supply Monthly, DOE/EIA-0109 (Washington, DC, various issues), Table 2; and Weekly Petroleum Status Report, DOE/EIA-0208(2000-12) (Washington, DC, March 24, 2000), Table 10.

Figure 3. U.S. Distillate Production by Month, 1994-2000

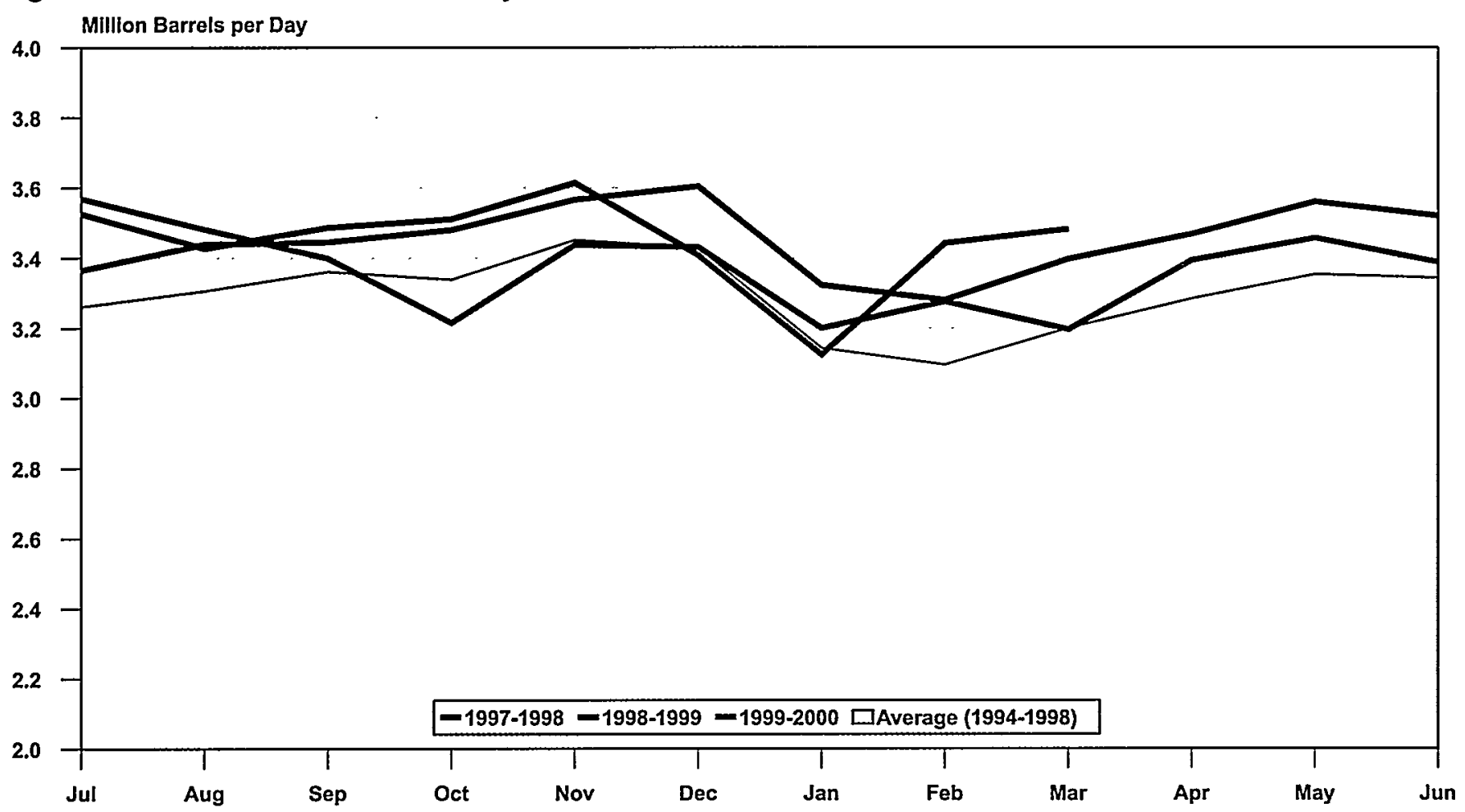

Source: Energy Information Administration, Petroleum Supply Monthly, DOE/EIA-0109 (Washington, DC, various issues), Table 2; and Weekly Petroleum Status Report, DOE/EIA-0208(2000-12) (Washington, DC, March 24, 2000), Table 10. 
Figure 4. Stocks of High-Sulfur Distillate Fuel Oil (Heating Oil) in New England (PADD 1a), 1994-2000

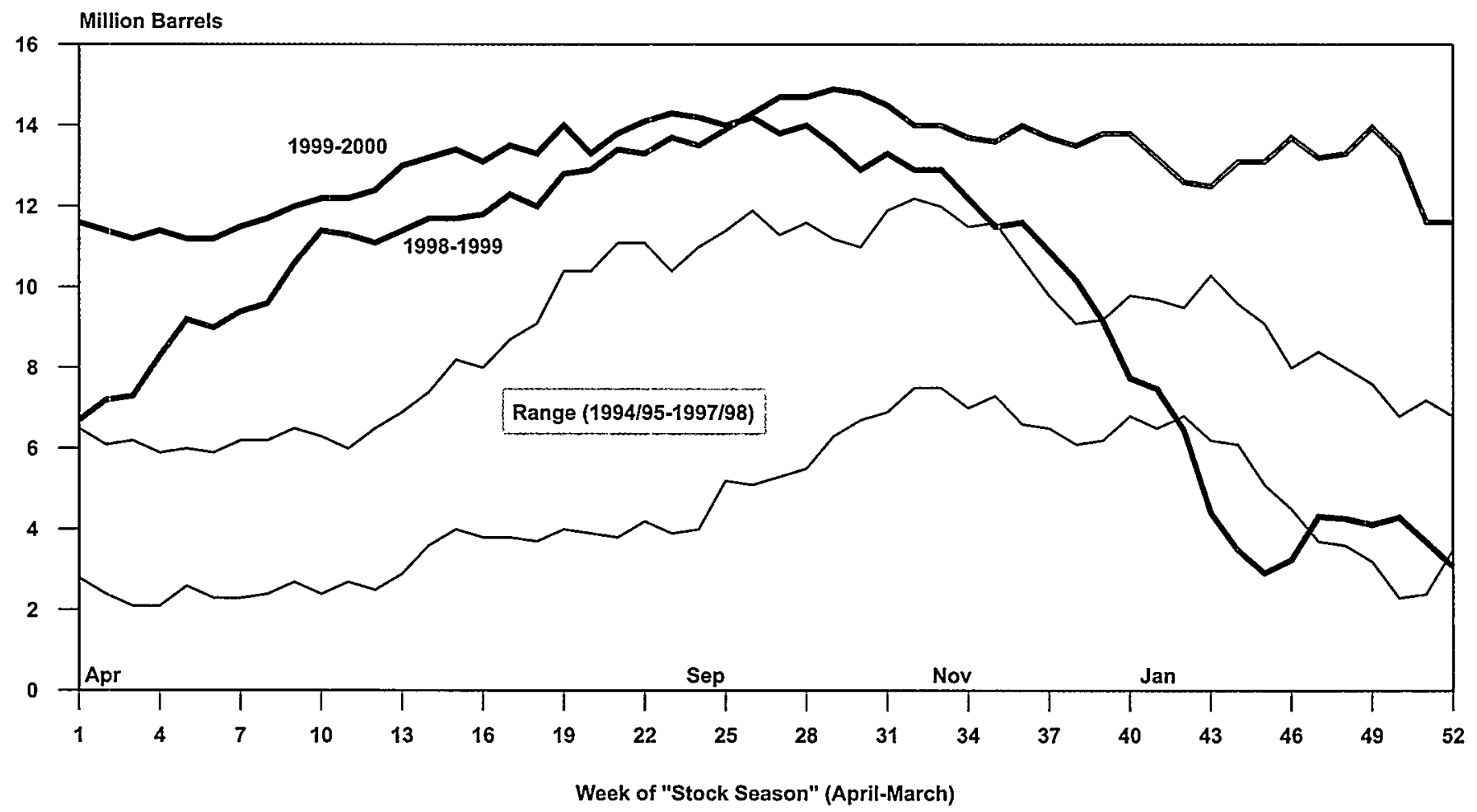

Note: The range represents the minimum and maximum stock levels by week between April 1994 and the end of March 1998.

Source: Energy Information Administration, Weekly Petroleum Status Report, DOE/EIA-0208 (Washington, DC, various issues), Table 10.

Figure 5. Stocks of High-Sulfur Distillate Fuel Oil (Heating Oil) in the Central Atlantic (PADD 1b), 1994-2000

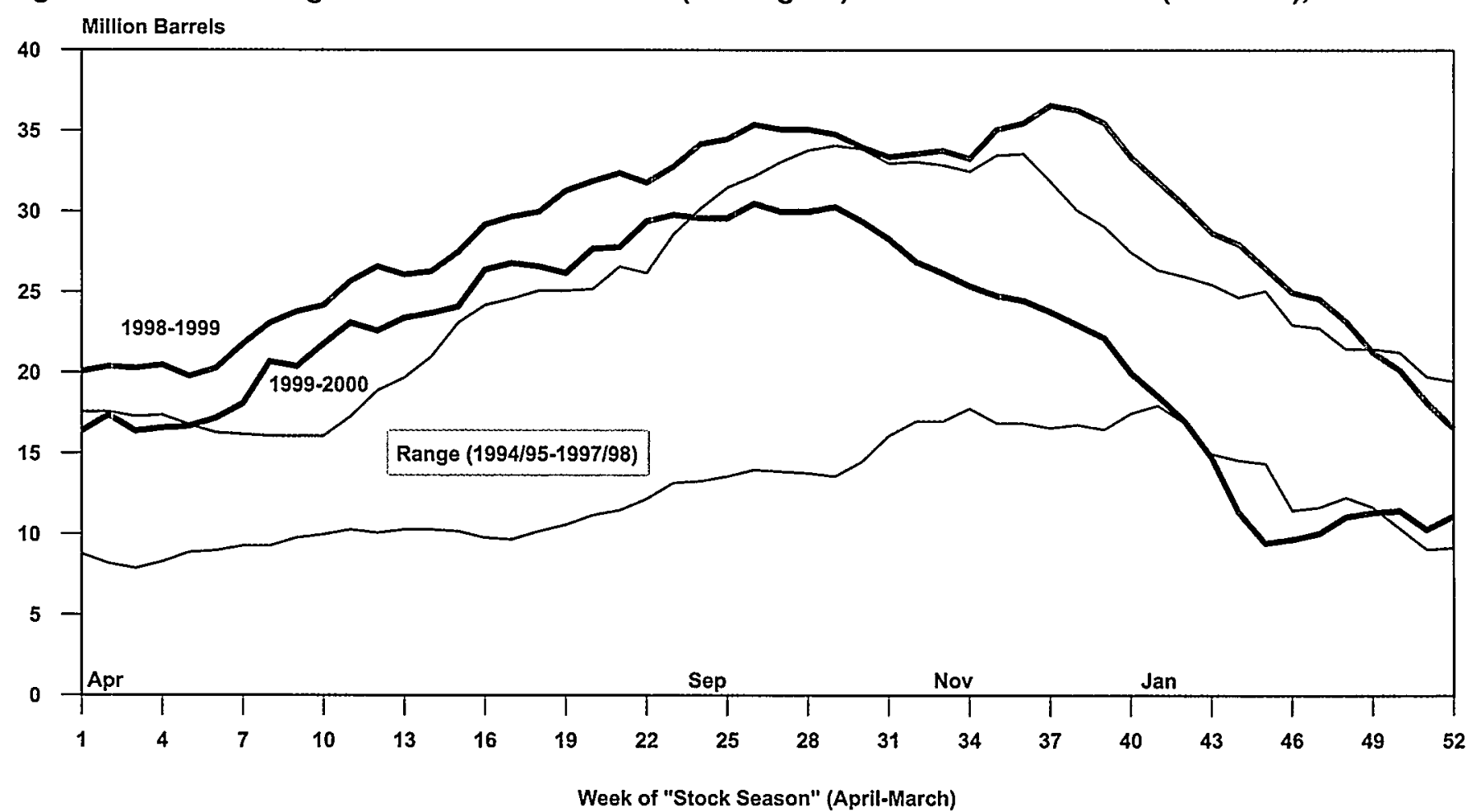

Note: The range represents the minimum and maximum stock levels by week between April 1994 and the end of March 1998.

Source: Energy Information Administration, Weekly Petroleum Status Report, DOE/EIA-0208 (Washington, DC, various issues), Table 10. 


\section{Prices and Stocks in December 1999}

At first glance, it is surprising that prices did not respond immediately to the large stock drawdown in December that moved inventories from normal to below normal. Typically, when distillate fuel oil stocks drop to low levels during the winter season, the spread between distillate fuel oil and crude oil prices increases. This was not the case in 1999. Historically, the spread between the New York Harbor spot price for heating oil and the price for West Texas Intermediate crude oil has averaged about 8 cents per gallon during December. In December 1999, even with low stock levels, the spread averaged only about 5 cents per gallon-about the same as it was in November.

Several factors may have contributed to the weak price response. First, after the December stock draw, stock levels did not hit the very low levels seen after similar historical periods when cold weather resulted in large stock draws and high prices. For example, at the end of December 1989 when there was a large price spike, stocks ended the month at 105.7 million barrels, well below the 124.1 million barrels at the end of December 1999. Second, year 2000 (Y2K) issues may have moderated the price response. The market may have believed the trade press articles that attributed much of the unusual drawdown to stocks being shifted from the primary level (e.g., bulk terminals and refineries) to the secondary level (distributor and retail storage). Third, the warm weather may also have lulled consumers into not worrying about supply. Finally, and related to the third point, there was no incentive for producers to buy expensive crude oil in order to build up distillate product stocks, given that consumption and prices were expected to decline. dramatic, as heating oil stocks fell from almost 30 million barrels at the beginning of November to less than 10 million barrels by early February. As at the national level, distillate demand on the East Coast was very high during December 1999-19 percent higher than in December 1998 and 36 percent higher than in the previous month.

The reasons for the large increase in demand in December 1999 are not clear. Cooler weather than in December 1998-8.4 percent more heating degree days in New England and 10.6 percent more in the Mid-Atlanticcontributed to but did not entirely explain the large increases in distillate fuel oil consumption in December 1999. In December, some energy analysts attributed the large demand to year 2000 (Y2K) actions (i.e., stockpiling for unexpected contingencies). ${ }^{16}$ EIA measures demand by the volume of product that leaves the primary distribution system. This product is either stored at small bulk plants (secondary storage), stored by retailers (secondary storage) or end users (tertiary storage), or consumed. One Y2K hypothesis was that much of the surprisingly high December volume was being shifted from primary to secondary or tertiary stocks, which were not being consumed. According to this hypothesis, the higherthan-expected demand in December would be countered by lower-than-expected demand in January when the shifted stocks were consumed. This theory proved to be incorrect, because end users did not appear to stockpile distillate fuel oil substantially. A second $\mathrm{Y} 2 \mathrm{~K}$ theory attributed some of the unexpected increase to utilities and other large natural gas users switching to oil in order to be off the natural gas pipelines during the $\mathrm{Y} 2 \mathrm{~K}$ rollover. This theory is consistent with the aggregate data, but EIA does not have detailed data to confirm it. Whatever the cause, the low stocks going into January left the Northeast vulnerable to the price spike that occurred when colder than normal weather brought rising demand and delivery problems.

\section{Natural Gas Market Factors Contributing to Distillate Fuel Oil Price Increases}

Going into the winter heating season of 1999-2000, both heating oil and natural gas supplies were relatively plentiful. Overall inventories in underground working gas storage were 3.0 trillion cubic feet, about 1 percent above the average for the past 5 years, although slightly below the record levels of the previous year. ${ }^{17}$ The supply outlook for the Northeast was strong with the expected opening of the Maritimes and Northeast Pipeline, which established a link between New England markets and the Sable Offshore Energy Project off the coast of Newfoundland. The pipeline began gas flow in early 2000, but operational difficulties limited the flow to below anticipated levels. Only 36 million cubic feet per day was making its way into U.S. markets before an operational problem forced a temporary shutdown. ${ }^{18}$ The pipeline was first forced to shut down on January 7 , 2000, due to hydrate formation in a subsea line (essentially, ice sludge blockage). The second shutdown

\footnotetext{
${ }^{16}$ Cambridge Energy Research Associates, Inc., "Ringing in the New Year with Backwardation and Y2K," CERA Alert (December 14, 1999).

${ }^{17}$ The American Gas Association (AGA) considers full gas storage capacity to be roughly 3.4 trillion cubic feet.

${ }^{18}$ By November 2000, the project is expected to deliver up to 400 million cubic feet per day to the Northeast-equivalent to about 70,000 barrels of heating oil or 65,000 barrels of residual fuel oil per day.
} 
occurred in mid-January, when the gas processing plant developed a gas leak and was again shut down for repair. Early gas flow reached about 110 million cubic feet per day, of which 36 million cubic feet per day entered U.S. markets. ${ }^{19}$ By early March, the gas flow was about 300 million cubic feet per day to markets in the United States. The Sable Island project is expected to reach flows of 450 million cubic feet per day by summer 2000 , the majority of which is expected to serve U.S. markets. $^{20}$

Although the availability of gas supplies was comparable to that of a year earlier, prices on both the spot and futures markets ${ }^{21}$ were significantly higher, in part because the prices of competing fuels were higher and also because higher consumption levels were expected if more normal weather patterns developed. In October 1999, gas wellhead and spot market prices were 35 percent and 60 percent higher, respectively, than in October 1998.

With the first wave of cold weather moving into the Northeast area in late December, spot prices for gas delivery at the New York citygate started to show substantial increases. ${ }^{22}$ In early December, delivered prices were generally below $\$ 3.00$ per million Btu. On December 20 and 21 , the price jumped by $\$ 0.23$ and $\$ 0.86$, respectively, to $\$ 4.11$ per million Btu, and ranged between $\$ 3.55$ and $\$ 4.87$ through December 29 (Figure 6). By December 30 the price had dropped to $\$ 3.07$ per million Btu, and trade press accounts noted that demand pressures had been reduced as utilities and other firms (primarily, industrial gas customers) shifted from natural gas consumption to oil for the $\mathrm{Y} 2 \mathrm{~K}$ rollover. While spot and futures prices generally trended upward during the first two months of year 2000, the most dramatic price swings were again seen at the New York citygate as the most extreme weather conditions of the winter reached the Northeast in mid-January. The New York citygate price rose from $\$ 2.65$ per million Btu on January 11 to $\$ 6.34$ on January 18. During the month from January 13 through February 13, citygate gas traded at prices above $\$ 6$ per million Btu on 21 days.

In late 1999 and early 2000, gas pipeline capacity into the Northeast was being used at heavy levels on segments

Figure 6. Spot Prices for Heating Oil and Natural Gas, August 1999 - March 2000

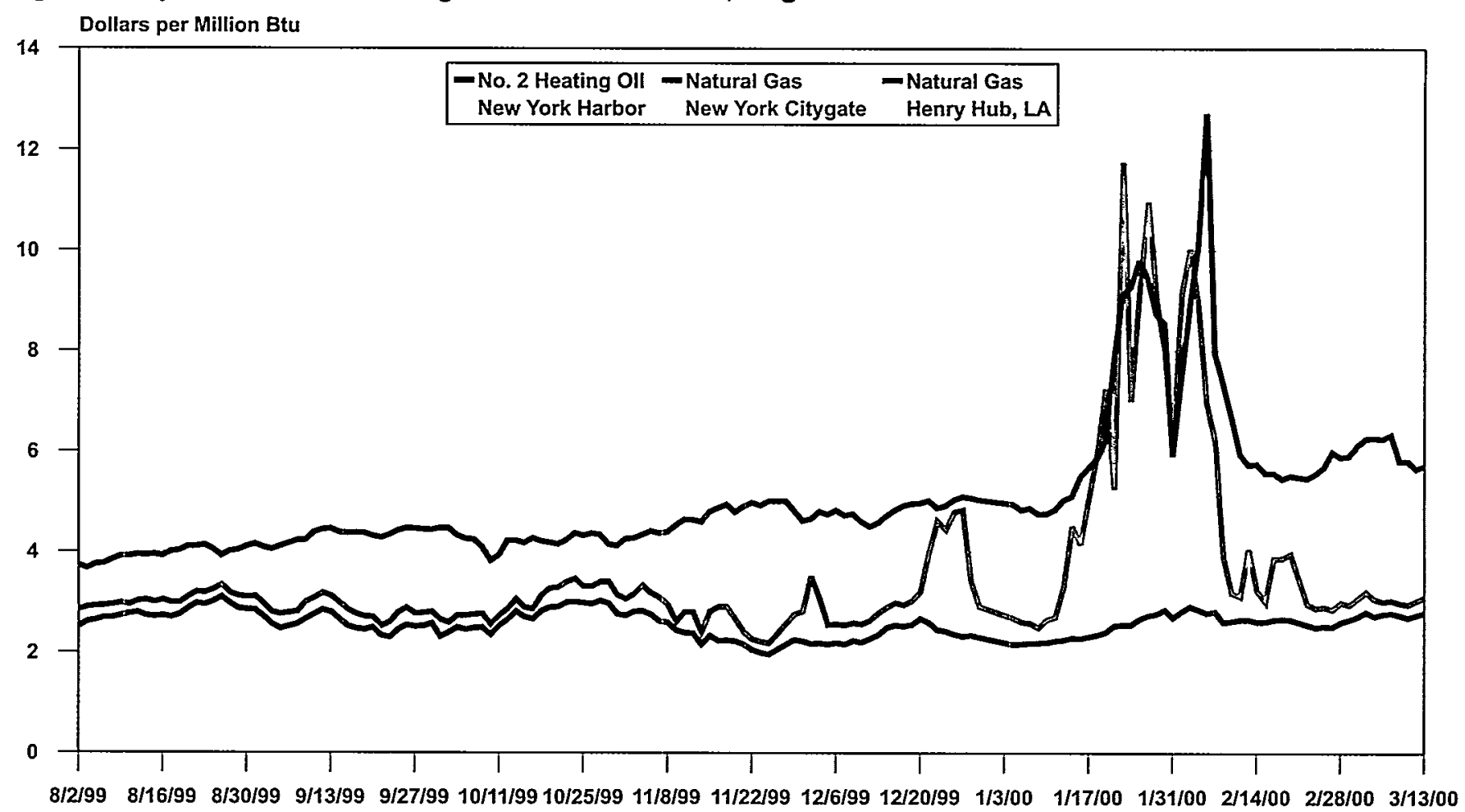

Sources: Reuters Daily No. 2 Heating Oil, New York Harbor (converted to dollars per million Btu using 5.825 million Btu per barrel), New York City Gate Natural Gas Prices, and Henry Hub Louisiana Natural Gas Prices.

${ }^{19}$ NGI's Daily Gas Price Index (January 18, 2000), p. 3.

${ }^{20}{ }^{N G I}$ 's Daily Gas Price Index (March 9, 2000).

${ }^{21}$ Spot prices, also known as "cash prices," are current market prices for immediate deliveries of the product. Futures prices, also known as "forward prices," are the prices of the commodity for delivery at a specified time and location in the future.

${ }^{22}$ The prices for gas traded at Transco Zone 6 are used as indicators of spot prices for the New York citygate. See Gas Daily (Arlington, VA: Financial Times). 
serving the Northeast region from New York up through New England. Pipelines carrying Canadian supplies to New England also experienced similar heavy usage. Several pipeline companies indicated that they had reached new peak levels for service. Officials from Transco, a major pipeline into the region, testified on February 24, 2000, that they had no interruptible capacity available on their system from October 20 to the date of the testimony. ${ }^{23}$ All requirements under firm service contracts were met, but some customers with interruptible service contracts did have their service interrupted. The new Maritime and Northeast Pipeline had been opened, but operational difficulties kept deliveries low. The limited availability of additional gas supplies above firm service volumes in the Northeast market had a significant impact on citygate spot prices.

The Northeast region, as well as most regions in the country, has seen dramatic increases in natural gas service over the past 10 years. But a very important operational characteristic of this regional market relative to many other major natural-gas-consuming regions is that the bulk of the supply arrives through a single supply corridor, or gateway, from the Southwest through Pennsylvania and New Jersey. Additionally, the Northeast markets are distant from the major supply areas of the U.S. Southwest and western Canada (Figure 7). Storage sites for natural gas are concentrated in western Pennsylvania, New York, and eastern Ohio, again requiring the gas to move an additional substantial distance to the market (Figure 8). Thus, the supply flexibility is more limited than in regions such as the area around Chicago that are both closer to the major producing regions and have multi-directional access to storage and other pipeline supplies. Gas supply difficulties in the Northeast are expected to abate once the Canadian Alliance Pipeline begins to deliver an expected 1.2 billion cubic feet of gas per year in 2001 to the Chicago area, much of which will be transported further into New England and the Middle Atlantic.

\section{The January/February 2000 Price Spike}

\section{Northeast Heating Oil and Natural Gas Spot Prices Spiked as Low Stocks Fell Further}

In mid-January, as a brief cold weather snap descended on the Northeast, New York Harbor spot heating oil prices soared from about 76 cents per gallon on January 14 to a peak of $\$ 1.77$ on February 4 before falling back. New York citygate natural gas prices rose from about $\$ 2.65$ per million Btu on January 11 to a peak of $\$ 11.75$ on January 21 (see Figure 6). Yet, while heating fuel oil and natural gas prices rose rapidly in the Northeast, natural gas prices at Henry Hub on the Gulf Coast and heating oil prices on the Gulf Coast rose very little, indicating the regional nature of the situation.

In response to the rise in spot and wholesale prices, residential heating oil and retail diesel fuel prices (i.e., distillate fuel oil prices) in the New England and Central Atlantic regions ${ }^{24}$ turned sharply upward in the third week of January (Figures 9 and 10). In the 3 weeks between January 17 and February 7, New England residential heating oil prices rose by 79 cents per gallon (66 percent), from $\$ 1.18$ to $\$ 1.97$. During the same 3-week period, New England retail diesel fuel prices rose by 68 cents per gallon (47 percent), from $\$ 1.44$ to a peak of $\$ 2.12$ per gallon.

Outside the Northeast, retail price increases for residential heating oil were relatively mild. In the Midwest, for example, residential prices rose by only 10 cents per gallon during the same 3-week period. The spike in the Northeast occurred as demand increased suddenly well above supply arrivals, driving already low distillate stocks to levels so low that some terminals reported runouts. ${ }^{25}$

\section{Weather Conditions Drove January Demand}

During the week ending January 22, temperatures in New England and the Middle Atlantic shifted from 15 percent and 17 percent warmer than normal, respectively, to 24 percent and 22 percent colder than normal. The rapid change in weather patterns increased weekly heating requirements for both distillate fuel oil and natural gas by about 40 percent.

Temperature declines during the winter affect heating oil demand in a number of ways:

- Space heating demand increases.

- Electricity peaking demand increases, and power generators must often turn to distillate to meet the new peak needs when natural gas is not an alternative.

- Fuel switching from natural gas to distillate occurs among some large customers with dual-fuel

\footnotetext{
${ }^{23}$ Testimony of Gary D. Lauderdale on behalf of Transcontinental Gas Pipeline Corporation before the Senate Committee on Energy and Natural Resources, February 24, 2000.

${ }^{24}$ New England includes Connecticut, Maine, Massachusetts, New Hampshire, Rhode Island, and Vermont. The Central Atlantic region includes Delaware, the District of Columbia, Maryland, and the Mid-Atlantic Census Division, which is composed of New Jersey, New York, and Pennsylvania (see map and discussion in Chapter 1).

${ }^{25}$ S. McCaffrey, "Heating Oil Companies Run Out in Some Areas," Albany Times Union (February 8, 2000).
} 
Figure 7. Natural Gas Pipeline Capacity Feeding into the Northeast, with Mileage from Major Supply Sources to Regional Distribution Centers

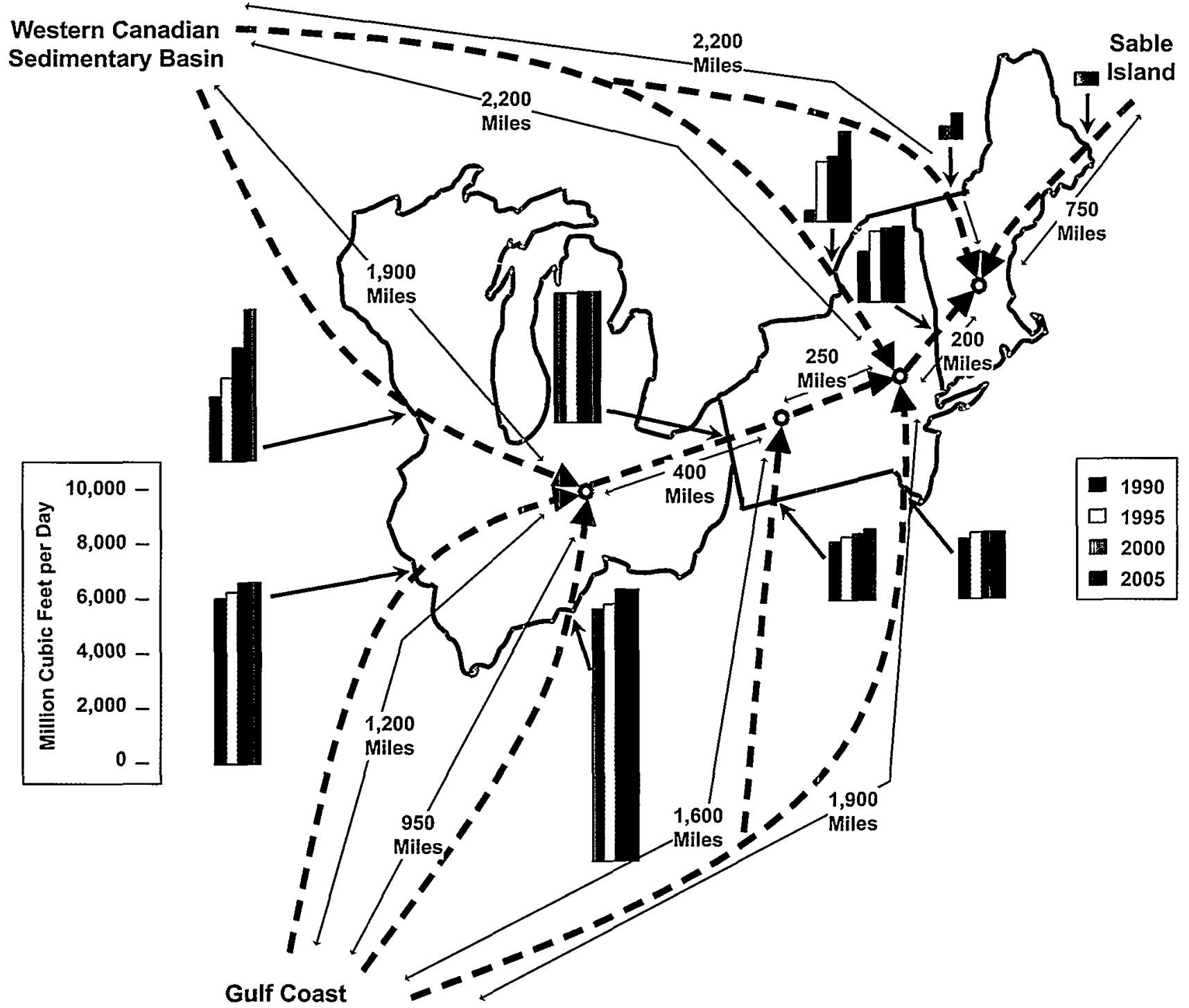

Note: The 2005 values reflect additions that were deemed likely to occur based on ongoing and announced projects.

Source: Energy Information Administration, Office of Integrated Analysis and Forecasting and Office of Oil and Gas.

capabilities-some by choice if distillate is cheaper, and some by the terms of their natural gas contracts.

U.S. demand for distillate fuel oil for all sectors increased by 22 percent in the second half of January 2000 relative to the first half of the month. Although regional demand data are not available on a weekly basis, East Coast demand would have been a substantial contributor to the increase, because it represents the majority of the U.S. heating oil market (see Chapter 3). East Coast distillate stock draw during these two weeks accounted for more than three-fourths of the Nation's stock draw. Yet the total January demand for distillate fuel oil was not unusually high, because the first half of the month had been relatively warm. As a result, the imbalance between supply and demand at the end of the month is obscured in the aggregated monthly data.

The extreme cold weather, coupled with rising natural gas spot prices in the Northeast during January and February indicated that natural gas customers with non-firm contracts probably were either switching voluntarily or being switched contractually from gas to oil to assure adequate gas supplies to firm contract customers, such as the residential market. The trade press reported that utilities, along with industrial and commercial users, were buying distillate for both peaking power and to substitute for natural gas supplies, as is frequently the case during high demand periods. ${ }^{26}$ Although EIA has not independently confirmed it, two

${ }^{26}$ J.P. Hamilton and M. Pittman, "Utility Contracts Exacerbate N.Y. Heating Oil Shortage," Bloomberg Nezusroom (January 26, 2000). 
Figure 8. Natural Gas Storage Sites in the Northeast

\section{Midwest \\ (East North Central)}

9 LNG Facilities

127 Underground Storage Facilities

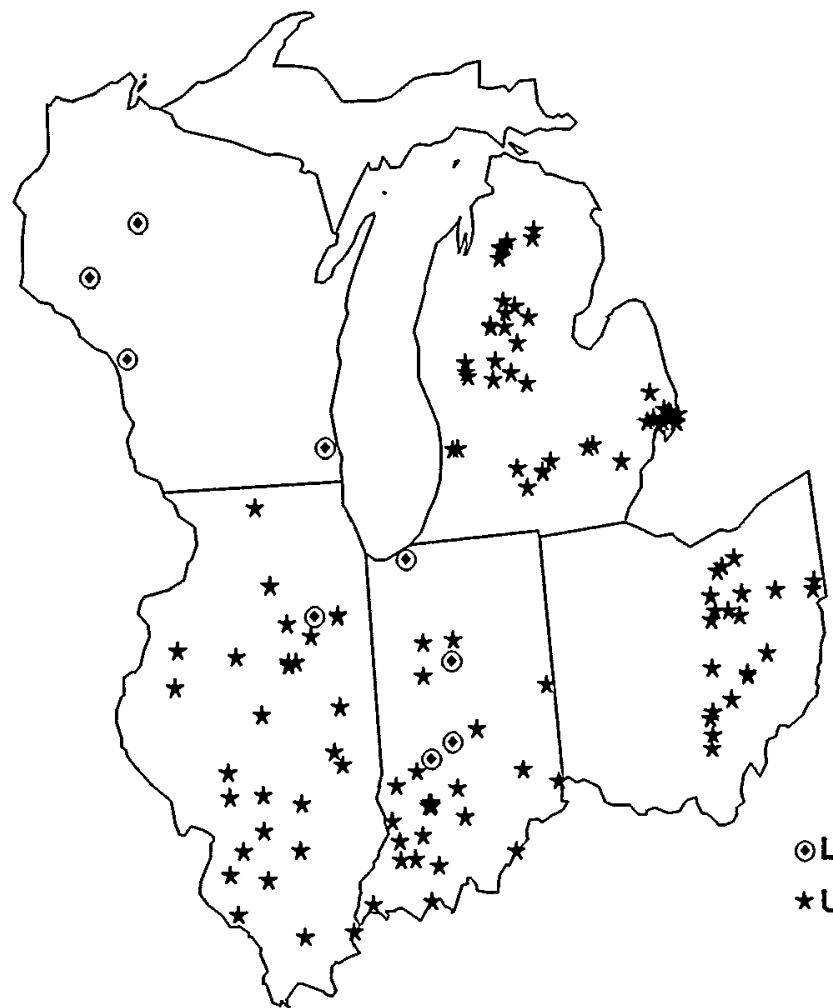

Northeast

(New England and Middle Atlantic)

43 LNG Facilities

82 Underground Storage Facilities

Note: See Chapter 4 of this report for more information on LNG storage.

Source: See Table 8 of this report.

Figure 9. Retail Residential Heating Oil Prices, Winter 1999/2000

Dollars per Gallon

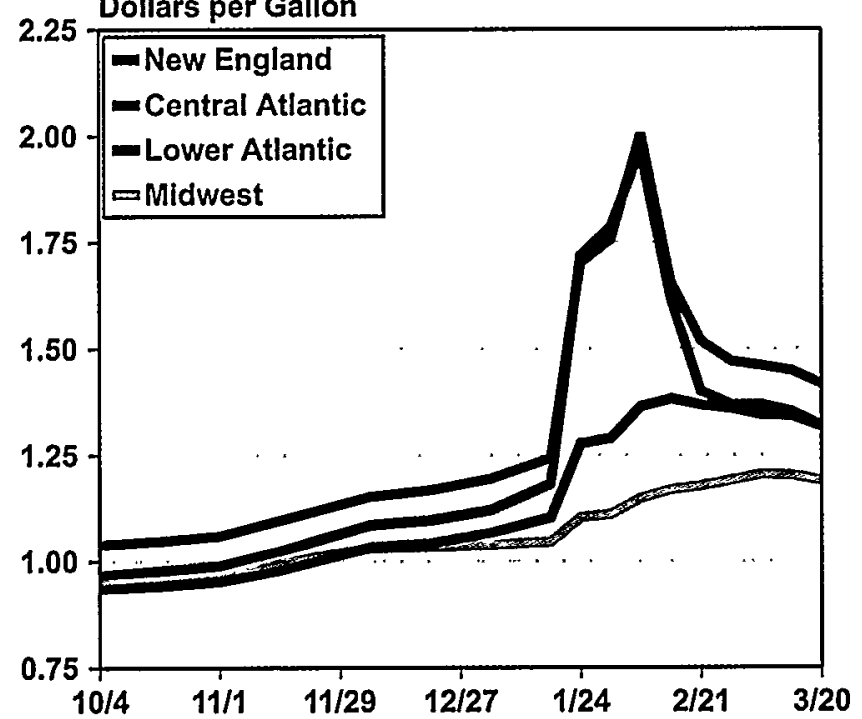

Source: Energy Information Administration, Weekly Petroleum Status Report, DOE/EIA-0208(2000-12) (Washington, DC, March 24, 2000), Table C3, based on data collected by State energy offices.
Figure 10. Retail On-Highway Diesel Prices, Winter 1999/2000

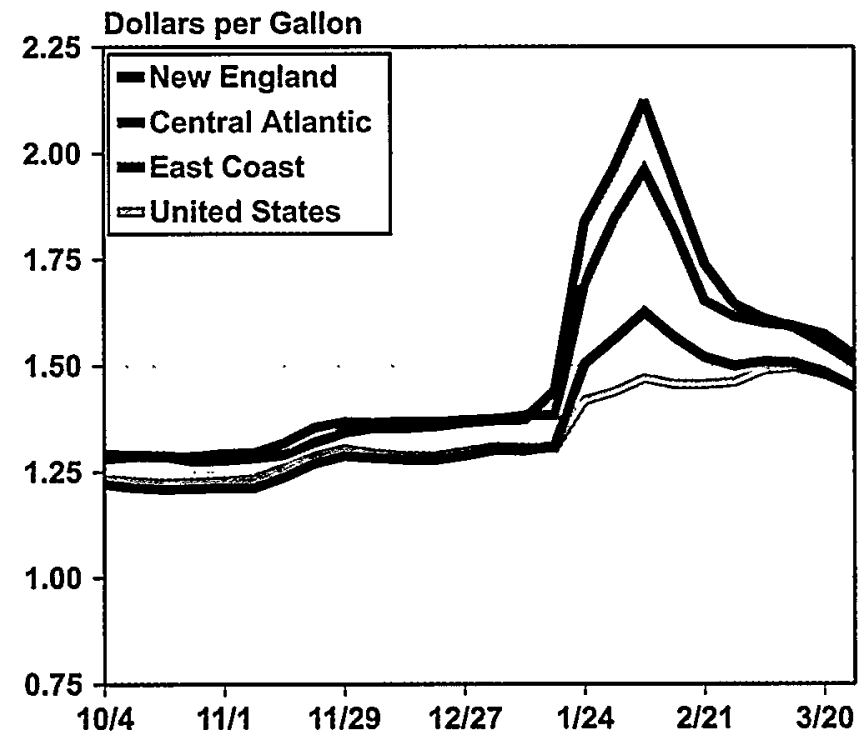

Source: Energy Information Administration, Weekly Petroleum Status Report, DOE/EIA-0208(2000-12) (Washington, DC, March 24, 2000), Table 18. 
sources in the trade press indicated that perhaps as much as 100,000 barrels per day may have been added to distillate fuel oil demand during the second half of January through early February as a result of fuel switching. ${ }^{27}$ This represents about 10 percent of the January 1999 demand for high-sulfur distillate oil on the East Coast ( 992,000 barrels per day)

\section{The Supply Situation Deteriorated While Demand Grew}

During the winter months, the Northeast depends on distillate fuel oil supply from nearby East Coast refineries and from distant sources such as the Gulf Coast and imports from other countries. It also depends on regional inventories (stocks), which are the closest source of supply to the end-use market and the first source of supply used when demand exceeds ongoing supply arrivals (see Chapter 5). If inventories are low and dropping when demand exceeds new supplies, prices usually rise rapidly. The high prices stimulate an increase in new supply, but because of the region's dependence on distant supply sources, increases in new supply can take several weeks or more to arrive, leaving prices elevated in the interim.

As noted above, low stocks of distillate fuel oil set the stage for the January/February 2000 price spike in the Northeast spot market for distillate fuel oil. Weekly data indicate that in the 4-week period ending February 4, 2000 , East Coast distillate stocks fell by almost 20 million barrels (41 percent), and outages occurred at some terminals. During the 4-week period, almost 700,000 barrels per day of demand was met with stocks (inventories). At the same time, the cold weather not only increased demand but also caused distillate fuel oil delivery problems, with frozen rivers and high winds along the New York, Connecticut, and Massachusetts coastlines hindering the arrival of new supplies by water into New York and Boston harbors.

Finally, refinery outages at the end of the week of January 21 resulted in a temporary loss of new supply and sent even more buyers into the distillate market, which added upward pressure on market prices. When refiners cannot produce distillate fuel oil to meet their contracts, they enter the spot market to purchase the product from others. EIA data do not indicate the volumes involved, but during such tight market conditions any increase in buying volume would lead to higher prices. With the arrival of new supply falling behind demand, stocks dropping to very low levels, and buyers knowing that any substantial new supply must come from distant sources, prices were bid up quickly.

\section{A Number of Events Eventually Corrected the Imbalance}

The imbalance between distillate oil supply and demand was resolved in February 2000 with the arrival of new supply and a return to warmer weather, which moderated demand and lowered the volume of interruptions in gas service. New supply can come from East Coast refineries, Gulf Coast refineries, and imports. Ultimately, the largest increases in new supply came from imports attracted by the high prices.

EIA data on the U.S. heating oil and diesel transportation fuel markets (Table 1) illustrate the dynamics of the recovery. On a regional basis, EIA's weekly distillate data are limited to production and stocks; however, the weekly U.S. data reflect much of what was occurring in the Northeast. Virtually all U.S. imports during the period of interest were delivered to the Northeast, and the changes in U.S. distillate fuel oil stocks mainly reflect changes in East Coast stocks.

During the three weeks ending February 25, distillate fuel oil imports averaged 566,000 barrels per day. During the preceding four weeks, imports averaged only 162,000 barrels per day. Refinery production on the East Coast also increased. For the three weeks ending February 25, East Coast distillate production averaged 478,000 barrels per day, which was an increase of about 91,000 barrels per day ( 24 percent) over the preceding four weeks (although national distillate production rose by only 7 percent). U.S. distillate stocks, which had fallen from 124.1 million barrels at the end of December 1999 to 106.7 million barrels at the end of January 2000, finally leveled off by February 18 at 99.3 million barrels and increased slightly through the remainder of February as the increased imports and refinery production balanced out the now lower demand. Prices receded both in the spot markets and at the retail level, although high crude oil prices in March 2000 continued to keep home heating oil and diesel fuel prices high relative to the previous year.

\section{What Will the Future Bring?}

The distillate price spike that began in January 2000 was the result of both demand and supply factors: cold weather creating a surge in demand, and logistics problems that coincided with low stocks in the regional market. Such tight market situations with accompanying price spikes are not uncommon in commodity markets, but for distillate fuel, such price spikes have not happened often. December 1989 and January/February

\footnotetext{
${ }^{27}$ Information provided to ELA by several State offices (discussed in more detail in Chapter 4); and Petroleum Industry Research Foundation, What Happened to Heating Oil (New York, NY, 2000), p. 6.
} 
Table 1. U.S. Distillate Fuel Oil Balance

(Thousand Barrels Per Day)

\begin{tabular}{|c|c|c|c|c|c|c|}
\hline Week Ending & $\begin{array}{l}\text { Product } \\
\text { Supplied } \\
\text { (Thousand } \\
\text { Barrels per Day) }\end{array}$ & $\begin{array}{c}\text { Production } \\
\text { (Thousand } \\
\text { Barrels per Day) }\end{array}$ & $\begin{array}{c}\text { Imports } \\
\text { (Thousand } \\
\text { Barrels per Day) }\end{array}$ & $\begin{array}{c}\text { Exports } \\
\text { (Thousand } \\
\text { Barrels per Day) }\end{array}$ & $\begin{array}{c}\text { Stock Build } \\
\text { (Draw) } \\
\text { (Thousand } \\
\text { Barrels per Day) }\end{array}$ & $\begin{array}{c}\text { Stock Level } \\
\text { (Thousand } \\
\text { Barrels) }\end{array}$ \\
\hline $01 / 14 / 2000 \ldots \ldots$. & 3,766 & 3,138 & 231 & 160 & (557) & 118,800 \\
\hline $01 / 21 / 2000 \ldots \ldots \ldots$ & 4,364 & 3,198 & 152 & 157 & $(1,171)$ & 110,600 \\
\hline $01 / 28 / 2000 \ldots \ldots \ldots$ & 3,866 & 3,267 & 160 & 147 & (586) & 106,500 \\
\hline $02 / 11 / 2000 \ldots \ldots \ldots$ & 3,866 & 3,471 & 528 & 147 & (14) & 99,500 \\
\hline $02 / 18 / 2000 \ldots \ldots$. & 3,716 & 3,392 & 452 & 157 & (29) & 99,300 \\
\hline $02 / 25 / 2000 \ldots \ldots \ldots$ & 3,761 & 3,445 & 718 & 159 & 243 & 101,000 \\
\hline 03/03/2000 ....... & 3,386 & 3,577 & 200 & 148 & 243 & 102,700 \\
\hline
\end{tabular}

Source: Energy Information Administration, Weekly Petroleum Status Report, DOE/EIA-0208 (Washington, DC, various issues), Table 10.

1994 are the only other instances in recent years. Although such spikes are short-lived, some residential users may be faced with financial hardships and even the fear of not being able to pay for fuel. Programs such as the Low Income Home Energy Assistance Program (LIHEAP) help low-income consumers of heating fuels during these infrequent and brief upheavals. If the market is left to function on its own, such spikes will likely occur in the future.

The remainder of this report focuses on the question of whether removing large customers from the distillate market will prevent or diminish the magnitude of price surges in the future. Large industrial, utility, and commercial customers represent incremental demand that can exacerbate price spikes. Two potential options are analyzed here: removing large fuel-switchable customers from the distillate fuel oil market completely during the winter heating season and moving some additional large-volume users of distillate fuel who currently do not have the capability to burn other fuels. To lay the groundwork for the discussion, the following chapters provide some background on how large customers in the Northeast use energy, why they choose one fuel over another, and how the energy infrastructure works to supply energy to large customers. 



\section{Consumer Markets: History, Patterns, and Outlook}

\section{Introduction}

This chapter provides the historical background of energy use trends and energy mix in the Northeast. The purpose of the analysis is to estimate the size of the distillate fuel oil market in the residential, commercial, industrial, and electricity generation energy sectors; to estimate how much of that might be switchable to different fuels; and to estimate what the absolute size of conversions might be if all large-volume nonresidential customers currently using distillate fuel oil switched to other fuels.

Until about 50 years ago, the mix of fuels in the residential and commercial sectors included a much larger proportion of coal than it does today. The coal share of energy use in those sectors has declined as the electricity and natural gas shares have increased. In the Northeast, the oil share of energy use relative to the natural gas share in all sectors is higher than in the rest of the Nation, primarily because petroleum products are more competitively priced and natural gas pipeline capacity to the Northeast is smaller than capacity for other urban centers, such as Chicago (in the Midwest Census region). ${ }^{28}$ Several factors have contributed to that condition. First, the cost of adding new pipeline capacity to the Northeast is relatively high, because the region is distant from U.S. gas supply sources. Second, natural gas has historically been considered a scarce and premium fuel that should be reserved for nonindustrial and non-electricity generation uses, reducing financial incentives to build new pipelines for those users. Third, the Northeast is readily accessible to ships carrying distillate and cheap residual fuel oil. Because residual fuel oil is relatively cheap-often between 70 and 90 percent of the crude oil price-and readily accessible to the electricity generation market, most of the switchable oil-steam units in the Northeast use residual fuel oil when they cannot have natural gas, or when natural gas is too expensive.

The Northeast is heavily dependent on distillate fuel oil, but the dependence is masked by the quantity of distillate fuel oil used for transportation (Figure 11). When transportation uses are removed, the dependence becomes more obvious (Figure 12). In the Northeast, residential use of distillate fuel oil dominates all other stationary uses (Figure 13). In 1997 (the most recent year for which historical data are available), residential use of
Figure 11. U.S. Distillate Fuel Oil Consumption, 1980-2005

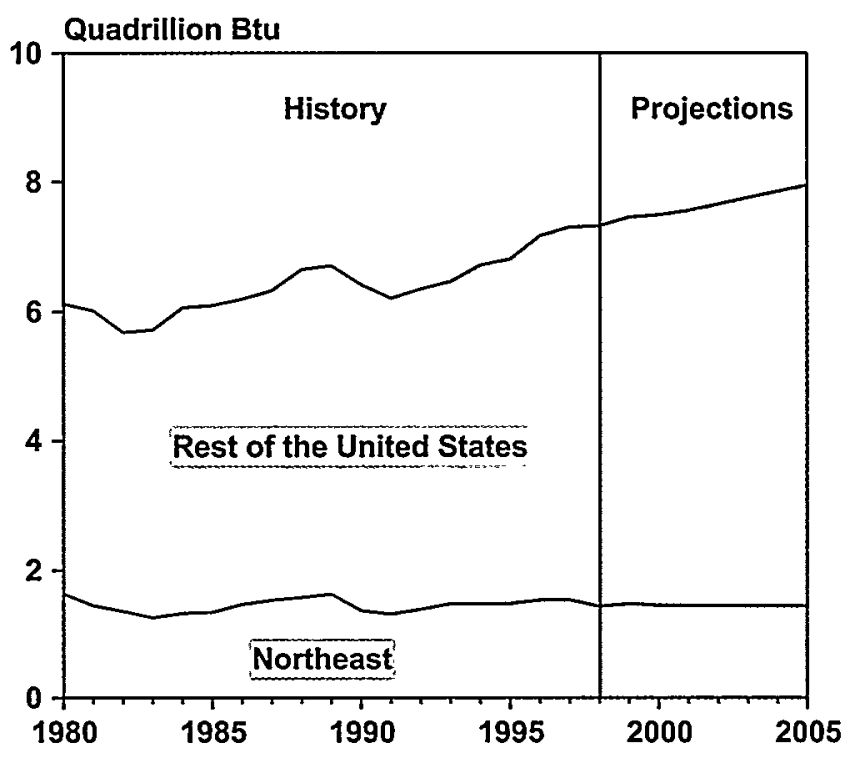

Note: One quadrillion Btu is equivalent to about 172 million barrels of distillate fuel oil.

Sources: History: Energy Information Administration, State Energy Data Report 1997, DOE/EIA-0214(97) (Washington, DC, September 1999). Projections: Energy Information Administration, Annual Energy Outlook 2000, DOE/EIA0383(2000) (Washington, DC, December 1999).

distillate fuel oil represented about 68 percent of all stationary distillate fuel oil use in the region.

\section{Residential Sector Heating Fuel Choice}

\section{Highlights}

- Residential distillate fuel oil use in the Northeast has declined by about 20 percent since 1980, as natural gas availability, energy efficiency, and warmerthan-average winter temperatures have decreased the amount of heating oil consumed in the region.

- Since 1992, heating oil prices in the Northeast have been lower on average than natural gas prices, allowing heating oil to retain market share in the region, although natural gas provides heat for 65 percent of all new single-family homes built in the

\footnotetext{
${ }^{28}$ The Midwest Census region is composed of Ohio, Indiana, Illinois, Iowa, Michigan, Wisconsin, Minnesota, Missouri, Kansas, Nebraska, North Dakota, and South Dakota.
} 
Figure 12. U.S. Distillate Fuel Oil Consumption, Excluding Transportation, 1980-2005

Quadrillion Btu

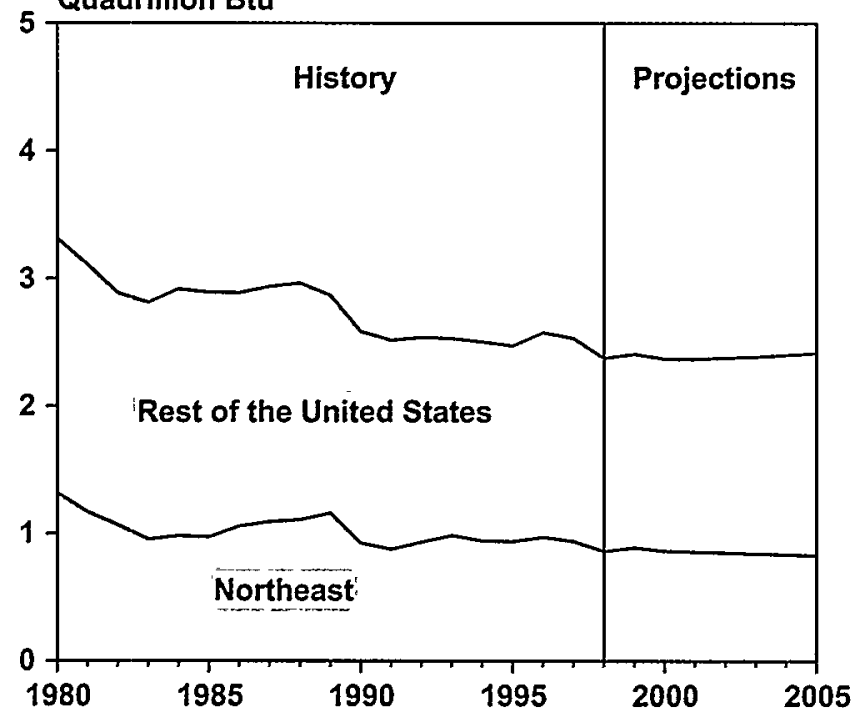

Note: One quadrillion Btu is equivalent to about 172 million barrels of distillate fuel oil.

Sources: History: Energy Information Administration, State Energy Data Report 1997, DOE/EIA-0214(97) (Washington, DC, September 1999). Projections: Energy Information Administration, Annual Energy Outlook 2000, DOE/EIA0383(2000) (Washington, DC, December 1999).

region, and thousands of residential customers switch from distillate fuel oil to natural gas each year.

- EIA's Annual Energy Outlook 2000 (AEO2000) projects that average distillate fuel oil prices in the Northeast will remain below average natural gas prices through 2005, even in the high world oil price case.

- An illustrative example, using actual residential billing data for heating oil and natural gas in Long Island, NY, indicates that total heating fuel costs over the past 20 years were nearly $\$ 1,800$ lower for this household heating with oil and using a 550-gallon underground storage tank than if it had heated with natural gas.

\section{Recent Trends and Current Use of Distillate Fuel Oil in the Residential Sector}

Heating oil accounted for about 8 percent of all energy delivered to the U.S. residential sector in 1997, and 73 percent of the total home heating oil was consumed in the Northeast Census region. ${ }^{29}$ While the total heating loads served by distillate fuel oil and natural gas are comparable between the Midwest and Northeast
Figure 13. Northeast Consumption of Distillate Fuel Oil, Excluding Transportation, 1980-2005

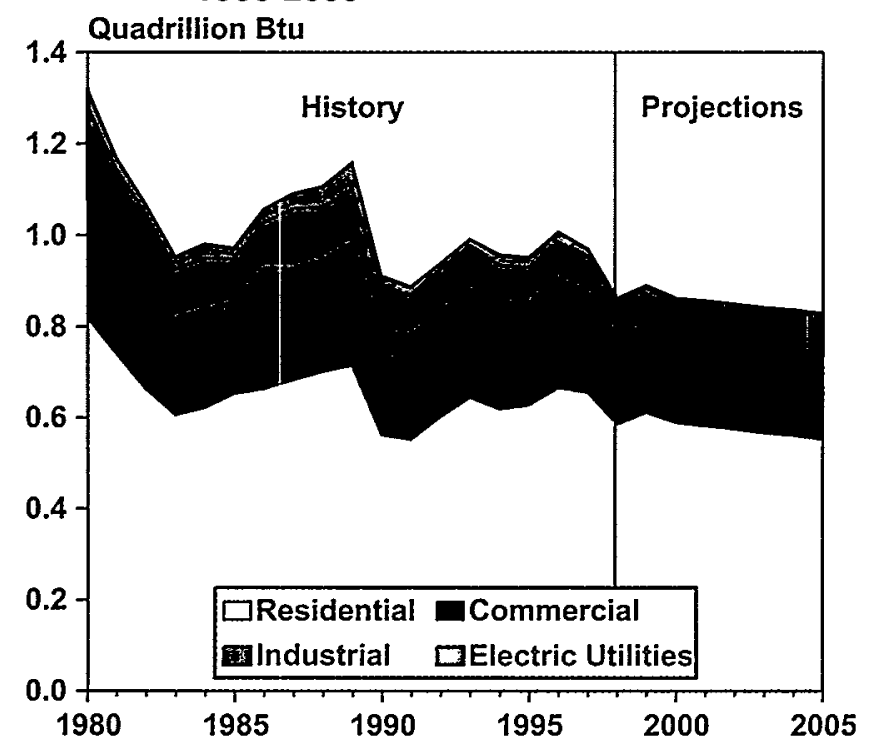

Sources: History: Energy Information Administration, State Energy Data Report 1997, DOE/EIA-0214(97) (Washington, DC, September 1999). Projections: Energy Information Administration, Annual Energy Outlook 2000, DOE/ElA0383(2000) (Washington, DC, December 1999).

regions, the shares of the two fuels were radically different in 1997: distillate fuel oil use for heating in the Midwest region was about 15 percent of that in the Northeast, and natural gas use for heating in the Midwest region was about 124 percent higher than in the Northeast. Households in the Northeast traditionally have relied on oil for heating because of the lower availability of natural gas and the competitive price of heating oil. ${ }^{30}$

Over the past 20 years residential oil use in the Northeast has declined as natural gas pipelines have been built, allowing newly constructed and existing homes to choose natural gas instead of heating oil. Figure 14 summarizes residential-sector distillate fuel oil consumption in the Northeast, the Midwest, and the rest of the United States over the past 20 years and its projected use through 2005. The effects of record warmth in the Northeast during the winters of 1990 and 1998, as well as a more "normal" winter in 1993, are easily discernible.

Residential consumption of distillate fuel oil in the Northeast has decreased by about 20 percent since 1980, and the number of heating oil customers has fallen by more than 10 percent. ${ }^{31}$ Gains in furnace and building shell efficiency and generally warmer winters have

\footnotetext{
${ }^{29}$ Energy Information Administration, State Energy Data Report 1997, DOE/EIA-0214(97) (Washington, DC, September 1999).

30Energy Information Administration, A Look at Residential Energy Consumption in 1997, DOE/EIA-0632(97) (Washington, DC, November 1999).

31 Energy Information Administration, Residential Energy Consumption Survey (RECS) data for 1980 and 1997.
} 
Figure 14. Distillate Fuel Oil Use in the Residential Sector, 1980-2005

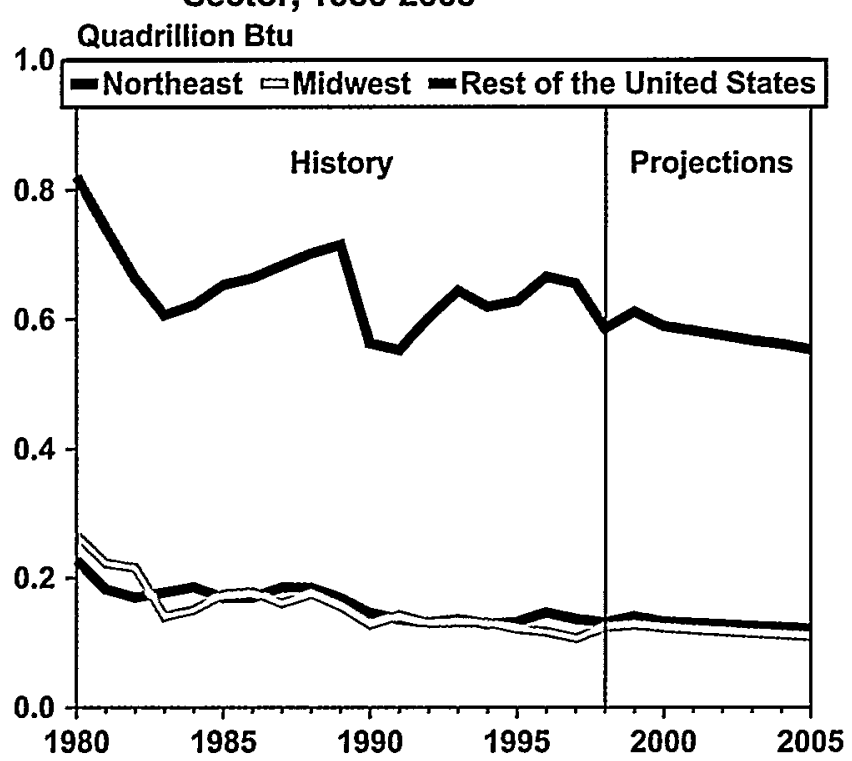

Note: One quadrillion Btu is equivalent to about 172 million barrels of distillate fuel oil.

Sources: History: Energy Information Administration, State Energy Data Report 1997, DOE/EIA-0214(97) (Washington, DC, September 1999). Projections: Energy Information Administration, Annual Energy Outlook 2000, DOE/EIA0383(2000) (Washington, DC, December 1999).

combined to decrease residential distillate fuel oil consumption relative to its 1980 level. Since 1993, however, the number of heating oil customers in the Northeast has remained relatively constant, and oil has maintained a 30-percent share in the heating market for new single-family homes, 32 offsetting the number of customers switching to gas over the same period. From 1982 to 1998, more than 1.6 million oil customers switched to natural gas nationwide. In 1998, it was reported that 13,255 oil customers ( 0.2 percent) in the Northeast switched to gas, nearly 82 percent less than the number of oil customers that switched to natural gas in 1992.33 Figure 15 shows the changes in heating fuel shares between 1980 and 1997.

\section{Projections to 2005}

Many factors contribute to heating fuel choice, including fuel availability, but fuel costs tend to be more important in times of price volatility. Perceived reliability of supply can also become an important criterion for fuel equipment choices, as was illustrated by the gas curtailments in the 1970s. Figure 16 shows heating oil and natural gas prices for the Northeast Census region from 1980 to 2005. Although the prices for the two fuels are competitive over most of the period, it is clear that oil prices have been lower since 1992, and they are projected to remain slightly lower through 2005.
Figure 15. Residential Heating Fuel Shares in the Northeast Census Region, 1980 and 1997

1980 1997

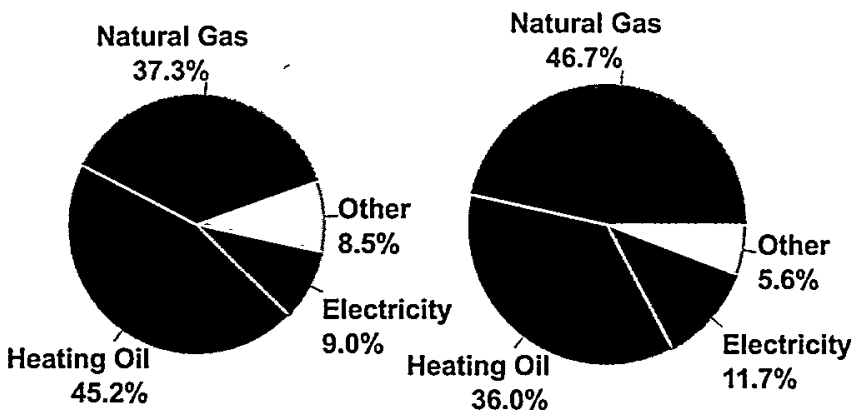

Note: The "Other" category includes kerosene, liquefied petroleum gas (LPG), renewables, and a small amount of coal.

Source: Energy Information Administration, Residential Energy Consumption Survey, DOE/EIA-0632(97) (Washington, DC, 1980 and 1999).

Figure 16. Residential Fuel Prices in the Northeast Census Region, 1980-2005 1999 Dollars per Million Btu

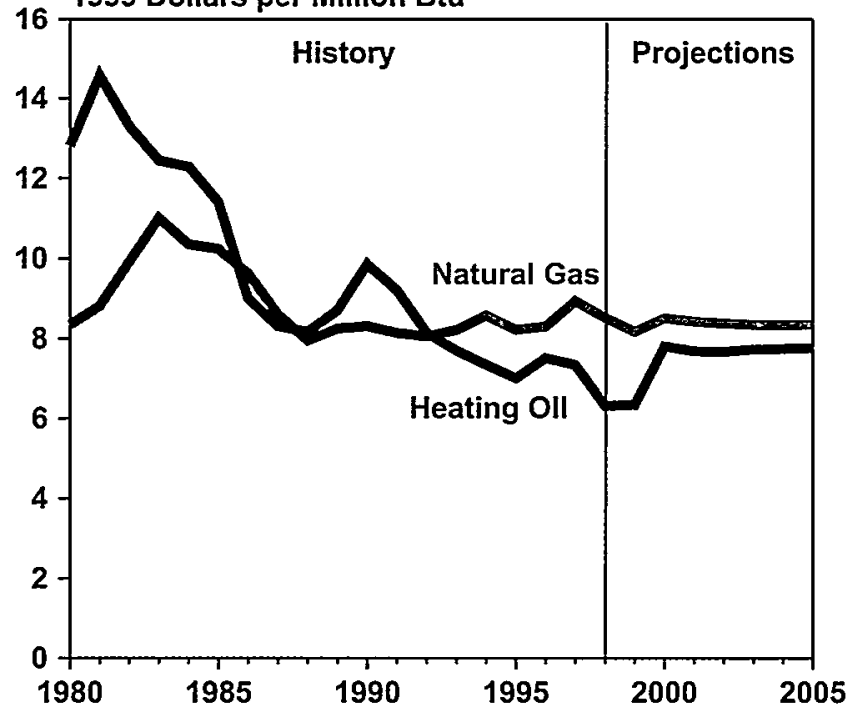

Sources: History: Energy Information Administration, State Energy Price and Expenditure Report 1995, DOE/EIA0376(95) (Washington, DC, August 1998). Projections: Energy Information Administration, Annual Energy Outlook 2000, DOE/EIA-0383(2000) (Washington, DC, December 1999).

If higher world oil prices were expected through 2005, as in the AEO2000 high world oil price case, heating oil prices would still be projected to remain below gas prices in the Northeast. With world oil prices reaching $\$ 24.48$ per barrel (1999 dollars) by 2005 in the high world oil price case ( $\$ 20.75$ in the reference case), residential heating oil prices in the Northeast would reach $\$ 8.37$ per

32U.S. Census Bureau, Current Construction Reports-Characteristics of New Housing: 1998, C25/98-A (Washington, DC, July 1999).

${ }^{33}$ American Gas Association, Residential Natural Gas Market Survey 1998 (Washington, DC, December 1999). 
million Btu ( $\$ 7.65$ per million Btu in the reference case), while natural gas prices would reach $\$ 8.48$ ( $\$ 8.24$ in the reference case). The price gap in 2005 between heating oil and natural gas narrows in the high world oil price case; however, the residential heating oil price still is projected to remain below the natural gas price.

\section{Historical Heating Costs: An Illustration}

About 7.1 million households heat with oil in the Northeast Census region, which accounts for 75 percent of distillate-heated households in the United States. ${ }^{34}$ Although retail heating oil is more susceptible to price volatility than natural gas, it has remained costcompetitive with natural gas over the past 20 years. During periods of high oil prices, however, a question arises as to why households in the Northeast choose not to convert from oil for space heating, especially in cases where gas is available to the households and is used for other applications, such as water heating and cooking. Of the 7.1 million homes that heat with oil in the Northeast, 2.4 million ( 34 percent) have gas service. ${ }^{35}$ Additional customers in the Northeast with no gas service into their homes are sufficiently close to gas distribution lines to have gas service installed at little or no cost but choose to heat with oil and cook with electricity instead. To examine the question, an analysis of energy bills for a house located in Long Island, NY, is provided below. ${ }^{36}$

The primary motivation for heating with oil rather than natural gas is economic, although perceptions of safety and reliability also play a role. Furnaces can last for 30 years or more, limiting the opportunity to switch fuels, especially since few homeowners retire heating equipment before it needs to be replaced. Even if gas service is already available in a home, a new furnace with installation can cost well over $\$ 2,000$-a significant economic barrier to conversion. Leaving that consideration aside, this case deals only with fuel costs, based on oil and gas bills collected from the homeowner. ${ }^{37}$

The study house uses oil for heating, with a 550-gallon below-ground storage tank. A tank of this size allows for oil purchases at lower prices during the summer months. The homeowner provided monthly oil usage readings, measured on the last day of each month, which were cross-referenced with documented oil deliveries for verification. The oil price in a given period was taken as the price per gallon that was paid for a delivery of oil until the full amount of the delivery was used, as determined from the usage readings and confirmed subsequent to the oil deliveries. The oil price and consumption data were converted to energy (Btu) equivalents to facilitate a comparison with a natural gas furnace of similar efficiency characteristics. Gas bills were provided for each 2-month billing cycle over the entire 20-year period. Given that the home was billed on a water heating schedule with low gas consumption, and because data for a comparable gas-heated home were not available for the entire period, the analysis assumed that the gas price would be discounted by 35 percent at higher usage rates (a declining tail block rate structure), which was estimated from partial billing data for a home in the same service territory with natural gas heat. Table 2 shows oil and gas prices as well as heating costs for the study household over the past 20 years.

Oil prices in the Northeast have generally been lower than gas prices, particularly over the past decade. The latest oil delivery, priced at $\$ 1.40$ per gallon ( $\$ 10.09$ per million Btu) on January 21, 2000, during the peak of the recent oil price spike, was only 5 percent more expensive than the estimated price for natural gas over the same period ( $\$ 9.63$ per million Btu). Assuming the same efficiency for oil and gas heating, over the past 20 years (through March 28, 2000), nearly $\$ 1,800$ (1999 dollars) in heating costs have been saved by the homeowner. For the 1999-2000 heating season (October 1, 1999, through March 28, 2000), heating costs for oil were $\$ 349$, as compared with an estimate of $\$ 563$ if the home had been heated with natural gas.

Even if oil and gas prices remain at their respective January 21,2000 , levels through 2005, annual heating costs for the study household would be $\$ 773$ using oil and $\$ 737$ using natural gas. Over the 6-year period (2000-2005), a total of $\$ 216$ in fuel costs would be saved by heating with gas. At a cost of $\$ 2,000$ for a new gas furnace, the simple payback period would exceed 50 years, much too long for such an investment to be made. Moreover, it is unlikely that such winter fuel price differentials would be sustained through 2005.

Whereas it is not feasible for residential customers to purchase natural gas in the summer months when prices are low and store it for later use, distillate fuel oil can be purchased and stored in oil tanks until needed. (On the other hand, degree-days and/or actual fuel levels must be accurately monitored to avoid running out of oil during cold winter months, whereas natural gas needs no

\footnotetext{
${ }^{34}$ Energy Information Administration, A Look at Residential Energy Consumption in 1997, DOE/EIA-0632(97) (Washington, DC, November 1999).

${ }^{35}$ Energy Information Administration, A Look at Residential Energy Consumption in 1997, DOE/EIA-0632(97) (Washington, DC, November 1999).

${ }^{36}$ Tables B1-B10 in Appendix B provide a historical comparison of residential equipment, fuel use, and expenditures for a variety of categories.

${ }^{37} \mathrm{Oil}$ and gas bills were provided to EIA for the period from October 1978 through March 2000 for a customer of Long Island Power Authority.
} 
Table 2. Residential Home Heating Case Illustration

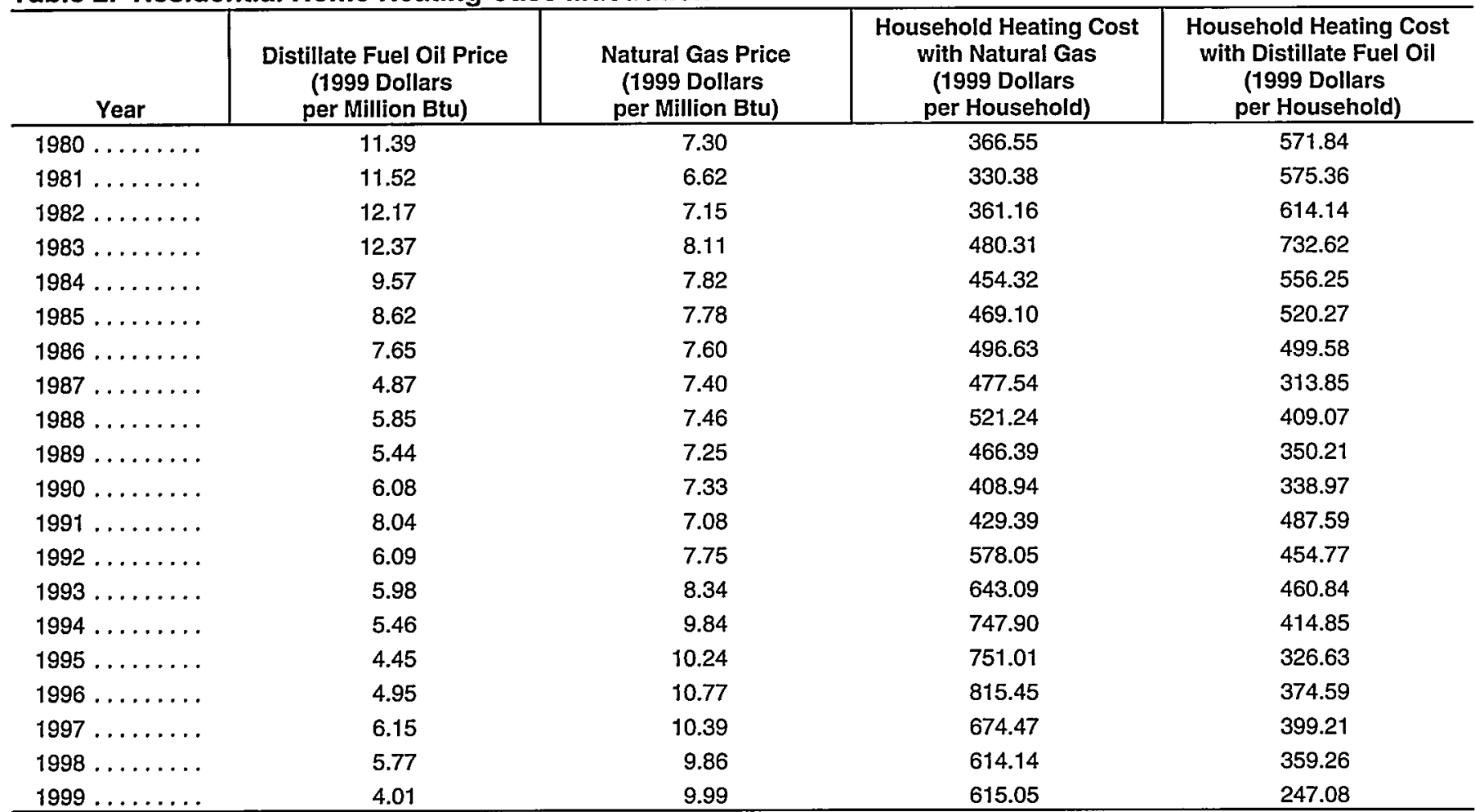

Source: Oil and gas billing records provided to EIA by the homeowner.

such monitoring.) For a residential fuel oil customer, concerns about oil supply and relatively high prices can be mitigated by well-timed fuel oil purchases, installation of a large fuel oil storage tank, and "cap" pricing contracts that place an upper limit on fuel oil prices for a small premium. ${ }^{38}$ For residential users, above-ground 275 -gallon tanks cost about $\$ 500$, and 550-gallon tanks (which must be buried) cost about $\$ 2,000$.

Transparent and timely data and information to home heating fuel consumers facilitate good planning and decisionmaking and improve market responses to potential price surges in the heating fuel market. The operational efficiency of the energy market is also likely to be enhanced by such market transparency.

\section{Conservation Options}

There is limited additional conservation potential in the Northeast residential sector with respect to distillate fuel oil consumption. Since 1980, distillate fuel oil consumption per household using oil has declined by more than 10 percent, reflecting efficiency gains in both equipment and building shell characteristics. Because most distillate fuel oil use is for space heating, fuel conservation can be achieved by adjusting thermostats down during the winter months or by installing setback thermostats, which automatically alter the thermostat setting either for times when the house is unoccupied or when higher settings are not needed. More expensive efficiency options, such as newer furnaces, better insulation, and multi-paned windows, can also help mitigate the perunit consumption of distillate fuel oil.

There is little, if any, opportunity for renewable energy sources to replace distillate use in the residential sector. The use of ground-source or water-source heat pumps can be considered renewable resources; however, electricity is needed to power the equipment, ventilation system, and pump, where appropriate. Solar energy can provide heat for part of the household load, but low insolation values ${ }^{39}$ and high costs restrict widespread use of this technology in the Northeast.

\section{Commercial Sector Fuel Choice}

\section{Highlights}

- In the Northeast, consumption of distillate fuel oil in the commercial sector has declined from 18 percent of commercial fuel use ( 257 trillion Btu or about 44 million barrels of distillate fuel oil) in 1980 to 12 percent ( 219 trillion Btu or about 38 million barrels) in

\footnotetext{
${ }^{38}$ Chapter 5 describes pricing options for distillate fuel oil at the wholesale and retail level in greater detail.

${ }^{39}$ Insolation is the rate of delivery of direct solar energy per square unit of horizontal surface area, often expressed in annual number of kilowatthours per square foot. Insolation values determine the viability of photovoltaics for a particular location.
} 
1997. In 1997, the commercial sector consumed about 22 percent of all nontransportation distillate fuel oil used in the Northeast.

- AEO2000 projects that the declining trend in commercial distillate fuel oil use will continue through 2005 , even in the low world oil price case.

- The maximum potential for Northeast commercial distillate fuel oil use that could be switched to another fuel in one week or less, without new equipment or retrofits, is about 50 trillion Btu (about 8.6 million barrels)-23 percent of the region's commercial distillate fuel oil use and 3 percent of its total distillate fuel oil use, based on 1997 consumption data.

\section{Recent Trends and Current Use of Distillate Fuel Oil in the Commercial Sector}

Distillate fuel oil use by commercial establishments in the Northeast is relatively small and declining. Northeast distillate fuel oil use in 1997 for all purposes totaled more than 1.5 quadrillion Btu (about 260 million barrels). Commercial distillate fuel oil consumption in the region has declined from 18 percent ( 257 trillion Btu or 44 million barrels of distillate fuel oil) of total commercial energy consumption in 1980 to 12 percent (219 trillion Btu or 38 million barrels) in 1997. In 1997, the commercial sector in the Northeast consumed about 1.8 quadrillion Btu of energy, or 12 percent of the region's

Figure 17. Commercial Delivered Energy Consumption in the Northeast Census Region by Fuel, 1997

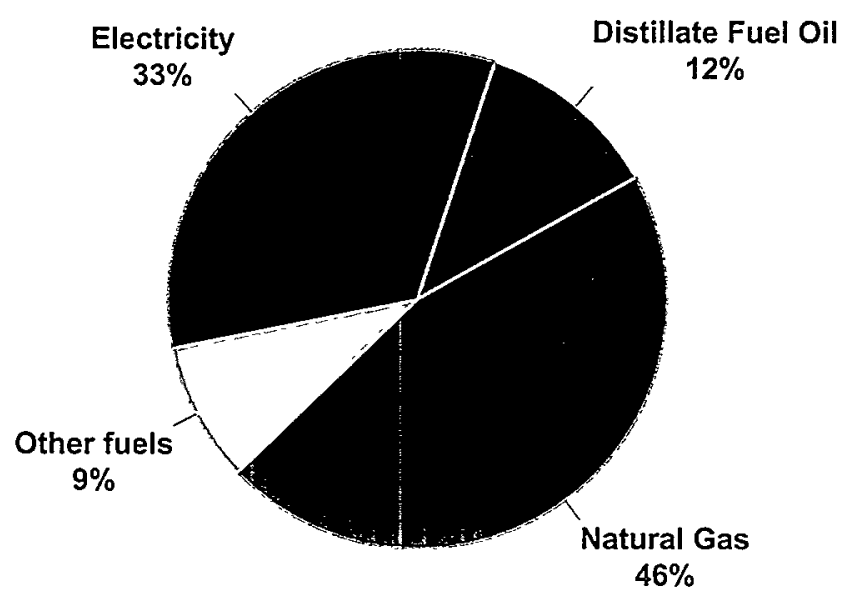

Note: Other fuels include liquefied petroleum gas (LPG), residual fuel oil, kerosene, motor gasoline, coal, and renewables.

Source: Energy Information Administration, State Energy Data Report 1997, DOE/EIA-0214(97) (Washington, DC, September 1999). total fuel use. Electricity and natural gas currently dominate Northeast commercial fuel use, followed by distillate fuel oil with a 12-percent share of energy delivered to the commercial sector (Figure 17).

Although distillate fuel oil represents only a relatively small proportion of total commercial sector energy use in the Northeast region, commercial use of distillate fuel oil in the region represents nearly half ( 49 percent) of U.S. commercial distillate fuel oil use. Nationally, distillate fuel oil's share of commercial sector energy consumption has declined steadily from 11 percent in 1983 to about 6 percent in 1997. The commercial fuel oil share in the Northeast has been more volatile than the national commercial consumption share, but overall it has decreased at nearly the same rate as the national share, from 18.5 percent in 1983 to 12.1 percent in 1997 (Figure 18). The factors that contributed to the declining trend in fuel oil use in the commercial sector, both nationally and in the Northeast, include increased natural gas infrastructure (pipelines and distribution systems), increased gas supplies to all markets, increasingly competitive natural gas prices, and improving equipment efficiencies.

To estimate the potential for reducing commercial sector distillate fuel oil use in the Northeast, it is necessary to understand how commercial consumers use distillate fuel oil. The latest available survey of commercial building end-use consumption is EIA's 1995 Commercial

Figure 18. Distillate Fuel Oil Share of Commercial Fuel Use, 1980-2005

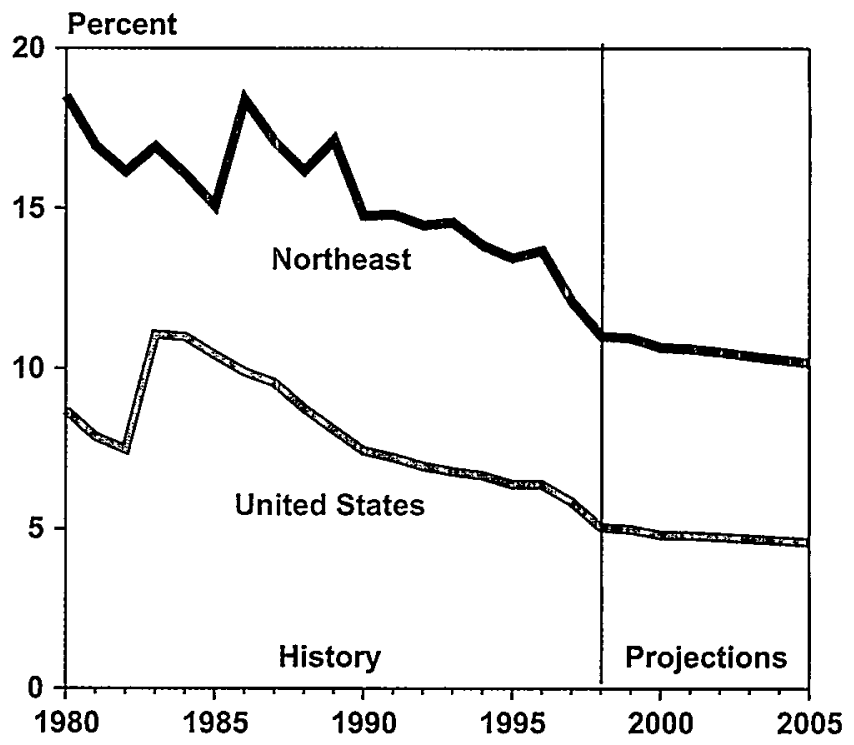

Sources: History: Energy Information Administration, State Energy Data Report 1997, DOE/EIA-0214(97) (Washington, DC, September 1999). Projections: Energy Information Administration, Annual Energy Outlook 2000, DOE/EIA0383(2000) (Washington, DC, December 1999). 
Buildings Energy Consumption Survey (CBECS95)..$^{40}$ The survey covers only energy use in buildings; any non-building energy uses, such as water treatment and sewer services, are not included. For this reason, the CBECS95 estimate of fuel oil use in commercial buildings in the Northeast is about 25 percent lower than the commercial distillate fuel oil use reported for the region in EIA's State Energy Data Report. ${ }^{41}$

The CBECS95 estimates of 1995 fuel oil use in commercial buildings totaled approximately 235 trillion Btu (about 41 million barrels) for the United States and 168 trillion Btu (about 29 million barrels) for the Northeast. 42 CBECS95 estimates for fuel oil use in commercial buildings in the Midwest Census region are very low by comparison, totaling 16 trillion Btu (about 2.8 million barrels). Fuel oil accounted for 16 percent of total fuel use in commercial buildings in the Northeast in 1995, a decline from 20 percent of total fuel use in 1983 (according to CBECS83). According to the CBECS95 estimates, 116 trillion Btu of fuel oil (about 20 million barrels) was used in 1995 to heat commercial buildings in the Northeast. The remainder was used for a variety of other building uses, such as water heating, cooking, and electricity generation (Figure 19).

The switchable portion of the market is the portion that can easily change fuels to serve demand (e.g., for space heating) and, potentially, have an immediate effect on fuel prices without installing new equipment or retrofits. In a well-functioning market, the ability to switch fuels should act to reduce the gap between retail oil and gas prices. Assuming that customers who can switch heating fuels can also switch fuel sources for other end uses, ${ }^{43}$ a total of 116 trillion Btu ( 20 million barrels distillate fuel oil equivalent) of energy use in commercial buildings in 1995 could have been provided either by oil or by natural gas (Figure 20). In 1995, more than half of that total (64 trillion Btu) was provided by natural gas, representing the maximum potential natural gas consumption in commercial buildings in the Northeast that could have been switched to distillate fuel oil use without new equipment or retrofits.

Fuel switching among commercial establishments that have identified themselves as dual-fuel capable usually does not occur except under special circumstances. Many use the alternate fuel capability as a backup and as a means to negotiate better primary fuel prices. However, large and prolonged price differences between distillate fuel oil and natural gas can also cause fuel
Figure 19. Commercial Sector Distillate Fuel Oil
Consumption in the Northeast
by End Use, 1995

Total $=225$ Trillion Btu

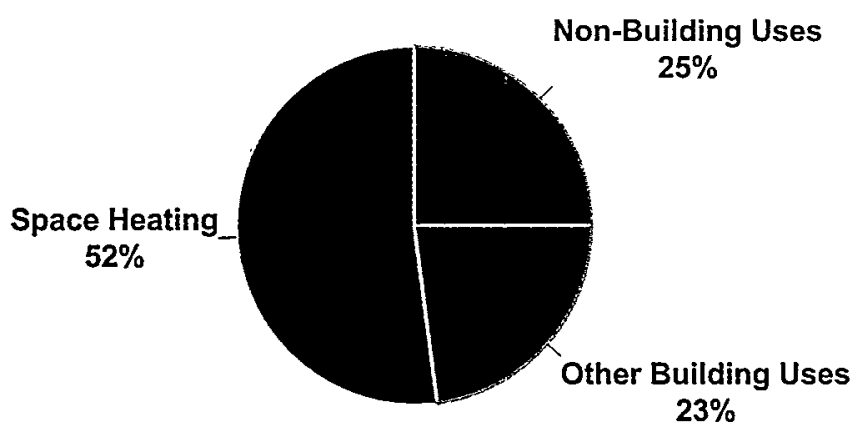

Source: Energy Information Administration, 1995 Commercial Buildings Energy Consumption Survey, Public Use Data, web site www.eia.doe.gov/emeu/cbecs/.

switching and conversions, as shown during several episodes in the 1980s. Conversions occur most often when equipment fails and new equipment is required.

The CBECS95 survey provides an estimate of total fuel oil consumption in buildings that use fuel oil for their main heating fuel. Fuel oil use is also estimated for buildings that can switch their main heating fuel source within a week's time, the CBECS survey criterion (Table 3). No information is available about the ability to switch fuel sources for other end-use services; however, assuming that commercial consumers who can switch their main heating fuel can also switch fuel sources for other end-use services (e.g., water heating), the maximum switchable distillate fuel oil use in 1995 for the Nation as a whole was 12 percent of total commercial distillate fuel oil consumption, or 9.8 million barrels. The maximum switchable percentage in the Northeast commercial sector was 23 percent (about 8.9 million barrels), reflecting the relatively high level of distillate fuel oil use in the region. In 1997, commercial distillate fuel oil use in the Northeast was 219 trillion Btu, of which about 50 trillion Btu would have been switchable to natural gas (based on the 1995 data and the above assumptions). A key question is whether switching from distillate fuel oil to another fuel would make sense, in terms of either

\footnotetext{
${ }^{40} \mathrm{As}$ with any sample survey, the results of CBECS95 contain a certain measure of error associated with individual data points. Point estimates are presented here for discussion purposes; however, for use in an analysis, survey results should be presented as a range of values with an associated probability.

${ }^{41}$ Energy Information Administration, State Energy Data Report 1997, DOE/EIA-0214(97) (Washington, DC, September 1999).

${ }^{42}$ Fuel oil estimates from CBECS95 consist primarily of distillate fuel oil but may include small amounts of residual fuel oil and kerosene.

${ }^{43}$ As such, this is an optimistic estimate of fuel-switching potential. The fuel-switching potential would be 35 to 40 percent lower if switching were limited to fuel use to provide heating.
} 
Figure 20. Natural Gas and Distillate Fuel Oil Use in Commercial Buildings in the Northeast and Maximum Fuel-Switching Potential, 1995 (Trillion Btu)

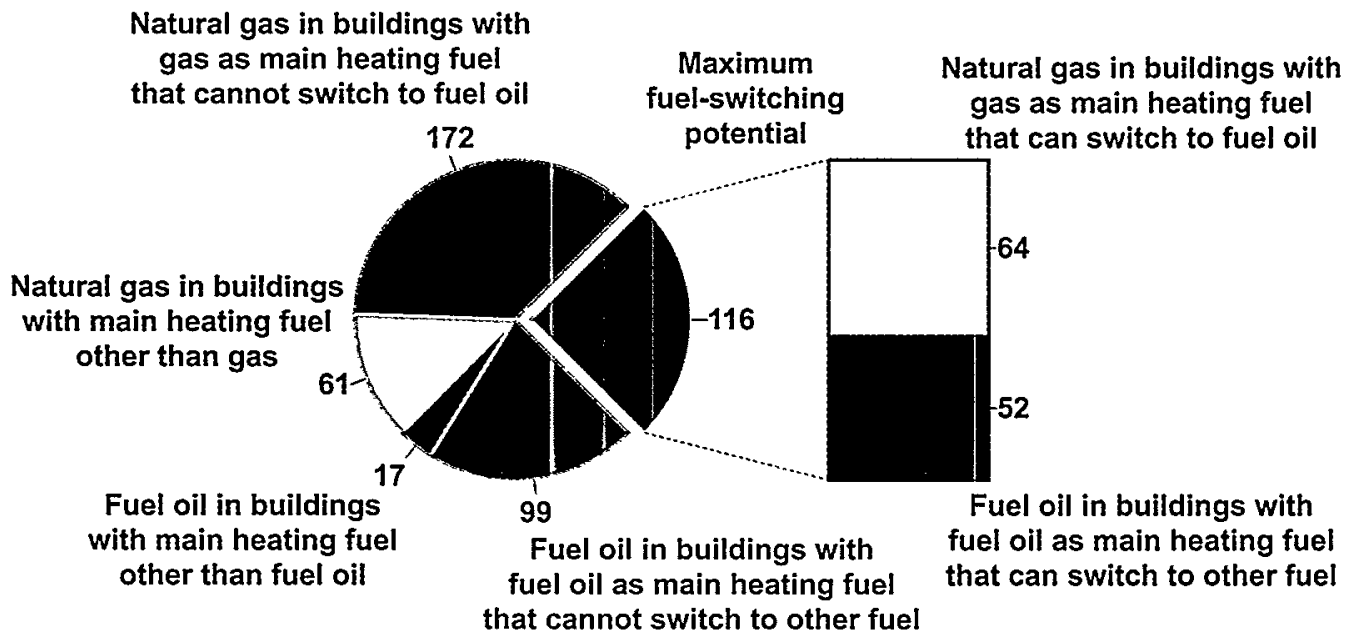

Source: Energy Information Administration, 1995 Commercial Buildings Energy Consumption Survey, Public Use Data, web site www.eia.doe.gov/emeu/cbecs/.

Table 3. Commercial Buildings Fuel Oil Consumption, 1995 (Trillion Btu)

\begin{tabular}{|c|c|c|}
\hline Fuel Oil Consumed for All Purposes & United States & Northeast \\
\hline Commercial sector, including non-building uses. . . . . . . . . & 460 & 225 \\
\hline Buildings using fuel oil for any purpose $\ldots \ldots \ldots$ & 235 & 168 \\
\hline Buildings using fuel oil as main heating fuel. . . . . . . . . . . . . . & 196 & 151 \\
\hline Buildings using fuel oil as main heating fuel that can switch fuel $\ldots \ldots \ldots \ldots$ & 57 & 52 \\
\hline
\end{tabular}

Sources: Energy Information Administration, State Energy Data Report 1997, DOE/ElA-0214(97)(Washington, DC, September 1999) and Energy Information Administration, 1995 Commercial Buildings Energy Consumption Survey, Public Use Data, http://www.eia.doe.gov/ emeu/cbecs/.

economic or reliability considerations, for commercial consumers.

\section{Projections to 2005}

In the $A E O 2000$ reference case, the projected prices for distillate fuel oil to commercial consumers in the Northeast are about the same as those projected for natural gas from 2000 through 2005 (Figure 21), reaching $\$ 5.66$ and \$5.72 (1998 dollars) per million Btu, respectively, in 2005. This assumes, of course, that the world oil market will work freely, without the coordinated production limits that have occurred in 1999 and early 2000. Northeast commercial distillate fuel oil demand in the reference case is projected to decline by 2.4 percent per year from 1997 to 2005, dropping to 184 trillion Btu by 2005, with a corresponding decline in fuel share to 10 percent of commercial fuel use. Higher fuel oil prices could accelerate that decline. Natural gas use in the Northeast is projected to increase by 0.2 percent per year in the reference case.

Two alternative oil price cases in AEO2000 illustrate the changes that might accompany higher or lower world oil prices. High world oil price assumptions (relative to the reference case) yield projected distillate fuel oil prices that are higher than commercial natural gas price projections in the Northeast through 2005. The opposite is projected under low world oil price assumptions (Figure 21). Varying world oil price assumptions result in corresponding differences in commercial distillate fuel oil use compared to the reference case (Figure 22). Although low oil prices yield 9 percent more Northeast commercial distillate fuel oil use in 2005 relative to the reference case, consumption is still projected to decline at a rate of 1.8 percent per year from 1997 through 2005. Commercial distillate fuel oil consumption is projected to be 6 percent lower than in the reference case in 2005 under the high world oil price assumptions, declining by 3.1 percent per year. Neither of these cases indicates how rapidly the market might actually change in the event of more frequent price surges for either fuel oil or natural gas.

\section{Conservation Options}

Conservation measures provide another method for reducing distillate fuel oil use in the commercial sector. The potential for additional conservation in distillate fuel oil use in the commercial sector includes both 
Figure 21. Ratio of Distillate Fuel Oil Price to Natural Gas Price in the Northeast Commercial Sector, 1980-2005

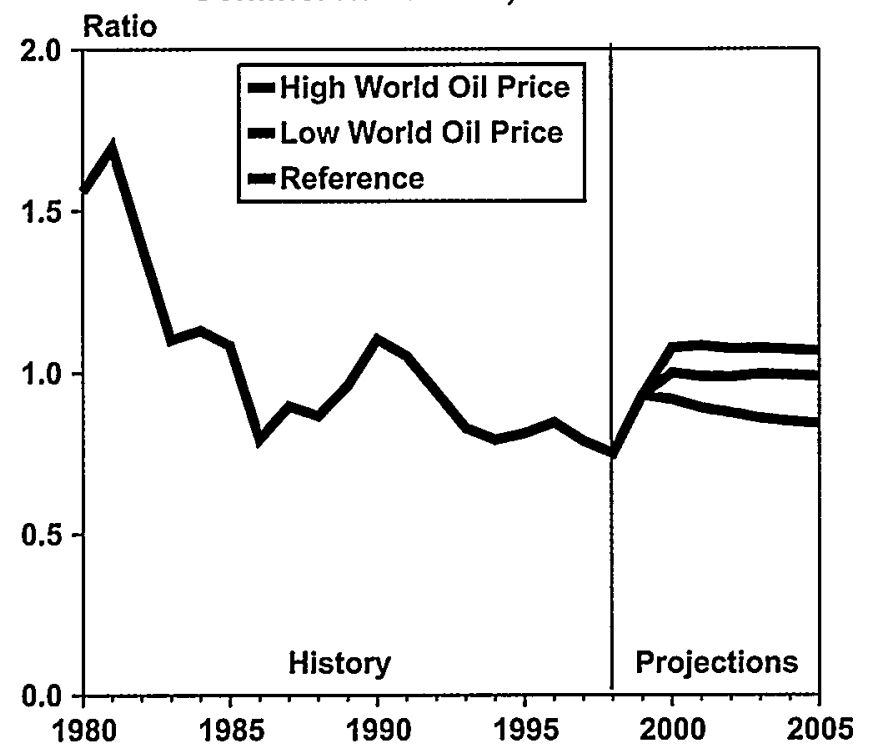

Sources: History: Energy Information Administration, State Energy Price and Expenditure Report 1995, DOE/EIA0376(95) (Washington, DC, August 1998). Projections: Energy Information Administration, Annual Energy Outlook 2000, DOE/EIA-0383(2000) (Washington, DC, December 1999).

Figure 22. Projected Distillate Fuel Oil Use in the Northeast Commercial Sector: Percent Change from Reference Case in Low and High World Oil Price Cases, 1999-2005

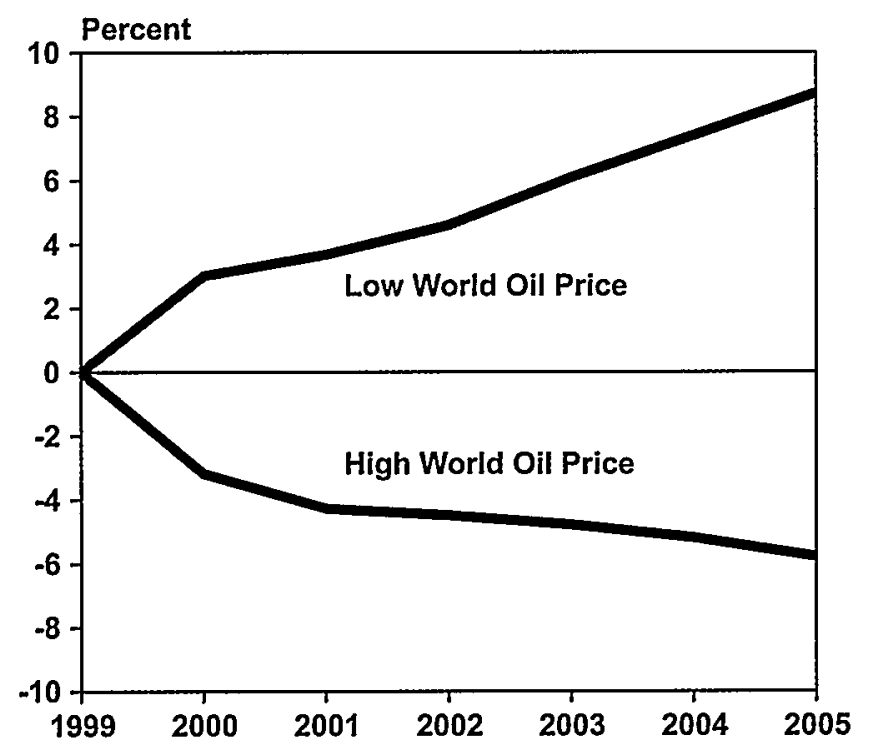

Note: One quadrillion Btu is equivalent to about 172 million barrels of distillate fuel oil. Six quadrillion Btu is equivalent to about 1 billion barrels of distillate fuel oil.

Source: Energy Information Administration, Annual Energy Outlook 2000, DOE/EIA-0383(2000) (Washington, DC, December 1999). short-term and long-term options. Immediate avenues for conservation are limited to actions related to energy management, such as reductions in heating during off-hours and reductions in hot water use. Permanent efficiency improvements provide opportunities for conservation over time, lessening the impact of any future fuel price volatility on the business that implements the improvements. Efficiency options include the purchase of new, efficient equipment and the installation of improved building shell measures, such as higher levels of insulation and windows that minimize heat loss. Conservation measures already employed by commercial businesses contributed to the significant decline in distillate fuel oil use observed since 1980 . The potential for additional conservation is limited to the implementation of additional energy management practices and efficiency measures beyond those already in place.

Limited opportunities exist in the commercial sector to displace distillate fuel use with renewable energy sources. Solar energy systems are currently more expensive than systems fueled by electricity or fossil fuels, even with net metering available to photovoltaic systems in many Northeastern States. Also, solar systems generally offset part of a commercial building's energy needs, with systems that run on electricity or fossil fuels required to meet the remaining load. Ground-source heat pumps provide another avenue for renewable energy to displace some distillate use, although some of the reduced distillate use would be offset with electricity requirements for heat pump operation. Unless solar and ground-source heat pump technologies are already in place, they would not be considered as cost-effective short-term fuel-switching options.

\section{Industrial Sector Fuel Choice}

\section{Highlights}

- Industrial distillate fuel oil consumption is a small part ( 5 percent) of the total Northeast distillate fuel oil market.

- More than half of industrial distillate fuel oil consumption in the Northeast is off-road diesel (41 trillion Btu of 79 trillion Btu).

- The maximum fuel-switching capability for industrial distillate fuel oil users in the Northeast without new equipment or retrofits is 9 trillion Btu (or 1.6 million barrels of distillate fuel oil), less than 1 percent of the region's total distillate fuel oil consumption.

- Based on the $A E O 2000$ high world oil price case, a 10-percent increase in distillate fuel oil prices would reduce industrial distillate fuel oil consumption in the Northeast by 2 trillion Btu (about 2.3 percent or 
about 345,000 barrels) in 2005 relative to the reference case projection.

\section{Recent Trends in Industrial Distillate Fuel Oil Consumption}

The industrial sector includes manufacturing, agriculture, mining, and construction. The industrial share of U.S. distillate fuel oil consumption has fallen since the mid-1980s, to about 16 percent in 1997 from about 22 percent in $1985,{ }^{44}$ although the actual quantity consumed has been relatively stable at about 1.1 quadrillion Btu. Total U.S. distillate fuel oil consumption has risen from about 6 quadrillion Btu in 1980 to about 7.2 quadrillion Btu in 1997 (Figure 23). Distillate fuel oil is a minor fuel in the industrial sector, representing only 4 percent of total energy consumption in 1997 (Figure 24).

In the Northeast, industrial distillate fuel oil consumption is a small part ( 5 percent) of the total regional market for distillate fuel oil. The 79 trillion Btu (about 14 million barrels) of industrial distillate fuel oil use in the Northeast during 1997 amounted to only 3 percent of industrial delivered energy in that region. The fraction of total Northeast distillate fuel oil consumption represented by the region's industrial distillate fuel oil consumption mirrors the national relationship, although the industrial share of total Northeast distillate fuel oil consumption (5 percent in 1997) is substantially less than the industrial share of U.S. total distillate fuel oil consumption (16 percent) because of the relatively large share of residential distillate use in the Northeast.

\section{Manufacturing and Nonmanufacturing Distillate Fuel Oil Consumption}

Further disaggregation of industrial distillate fuel oil consumption is required to assess the prospects for reducing distillate fuel oil consumption by increasing consumption of substitute fuels. Within the manufacturing component of the industrial sector, there is some ability to switch boiler fuels, whereas in the nonmanufacturing component (agriculture, mining, and construction) the substitution possibilities are limited. In the latter components, distillate fuel oil is primarily used in farm equipment and other off-road vehicles rather than as a heating source.

Nonmanufacturing distillate fuel oil consumption (primarily diesel fuel) has accounted for about two-thirds (747 trillion Btu in 1997) of nationwide industrial distillate fuel oil consumption in recent years (Table 4). In the Northeast, however, consumption is almost evenly split between the two components, with 41 trillion Btu (about 7.1 million barrels) in the nonmanufacturing segment and 38 trillion Btu (about 6.6 million barrels) in
Figure 23. Total and Industrial Distillate Fuel Oil Consumption in the United States, 1980-2005

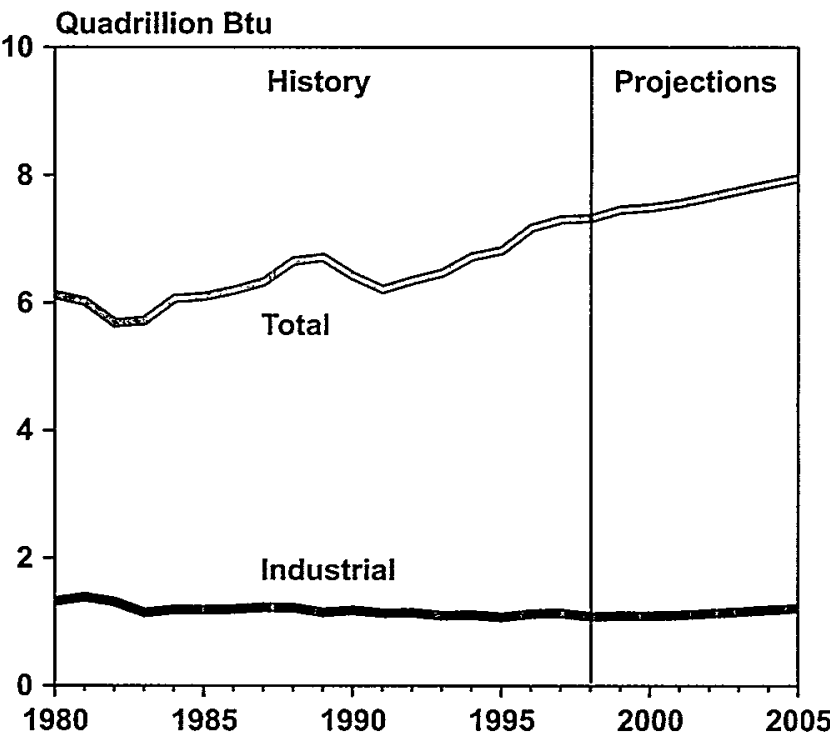

Note: One quadrillion Btu is equivalent to about 172 million barrels of distillate fuel oil. Six quadrillion Btu is equivalent to about 1 billion barrels of distillate fuel oil.

Sources: History: Energy Information Administration, State Energy Data Report 1997, DOE/EIA-0214(97) (Washington, DC, September 1999). Projections: Energy Information Administration, Annual Energy Outlook 2000, DOE/EIA0383(2000) (Washington, DC, December 1999)

\section{Figure 24. Distillate Fuel Oil Share of Industrial Delivered Energy Consumption in the United States and the Northeast, 1980-1997}

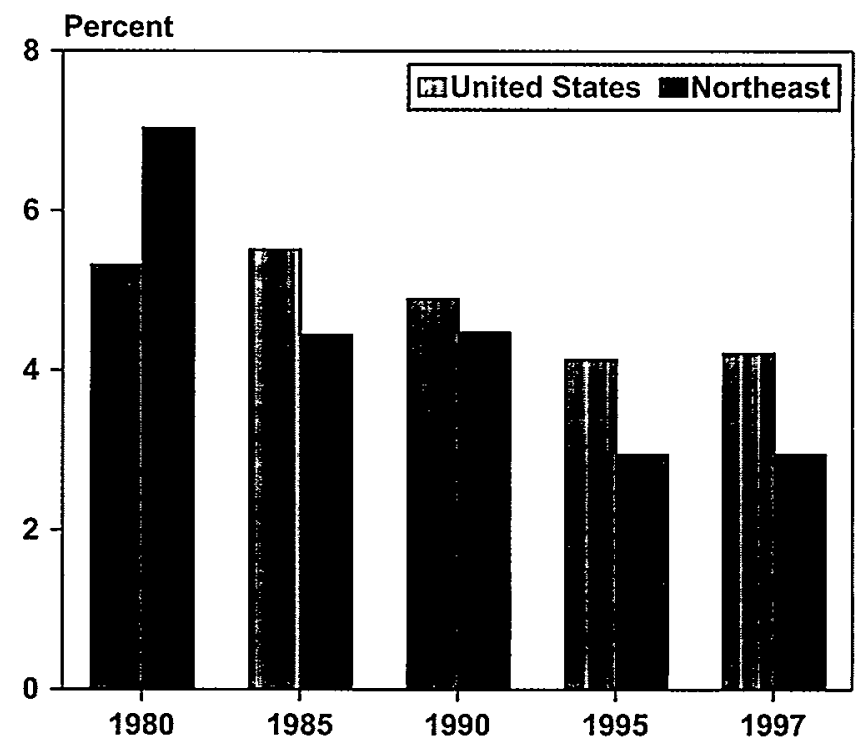

Source: Energy Information Administration, State Energy Data Report 1997, DOE/EIA-0214(97) (Washington, DC, September 1999).

\footnotetext{
${ }^{44}$ Energy Information Administration, Fuel Oil and Kerosene Sales 1998, DOE/EIA-0535(98) (Washington, DC, August 1999), and earlier issues.
} 
the manufacturing segment. Consequently, potentially switchable industrial distillate fuel oil consumption in the Northeast in 1997 was 38 trillion Btu or 6.6 million barrels, or 2.5 percent of the region's total distillate fuel oil consumption. Of that amount, however, only 24 percent was actually switchable (i.e., the consumption was by industrial concerns that either had equipment with dual-fuel capability or had second boilers that could actually be fired up to operate in place of the other fuel).

\section{Industrial Distillate Fuel Oil Switching Potential}

Data on fuel switching in the manufacturing sector for 1994 are available from EIA's 1994 Manufacturing Energy Consumption Survey (MECS94). MECS94 shows total U.S. manufacturing distillate fuel oil consumption of 152 trillion Btu (Table 5), including 42 trillion Btu for boiler fuel and 51 trillion Btu for direct process energy. Onsite transportation accounted for 35 trillion Btu, and facility heating, ventilation and air conditioning (HVAC) accounted for another 7 trillion Btu. (On-site transportation involves movement of materials within a plant site, not transportation among different sites.)

The pattern for the Northeast is similar (Table 6), except for facility heating. In the Northeast, MECS reported 41 trillion Btu of distillate fuel oil consumed for all purposes. Boiler fuel accounted for 15 trillion Btu. The

\section{Table 4. Industrial Distillate Fuel Oil Consumption, 1994-1998} (Trillion Btu)

\begin{tabular}{l|r|r|r|r}
\hline & 1994 & 1995 & 1996 & 1997 \\
\hline United States & & & & \\
Manufacturing ...... & 388 & 358 & 379 & 388 \\
Nonmanufacturing... & 720 & 717 & 749 & 747 \\
Total .......... & 1,107 & 1,075 & 1,128 & 1,135 \\
Northeast & & & & \\
Manufacturing ...... & 45 & 40 & 40 & 38 \\
Nonmanufacturing... & 41 & 38 & 42 & 41 \\
Total ........... & 86 & 78 & 82 & 79 \\
\hline
\end{tabular}

Source: Energy Information Administration, Fuel Oil and Kerosene Report 1998, DOE/EIA-0535(98) (Washington, DC, August 1999), and earlier issues.

Table 5. U.S. Manufacturing Energy Consumption, 1994

(Trillion Btu)

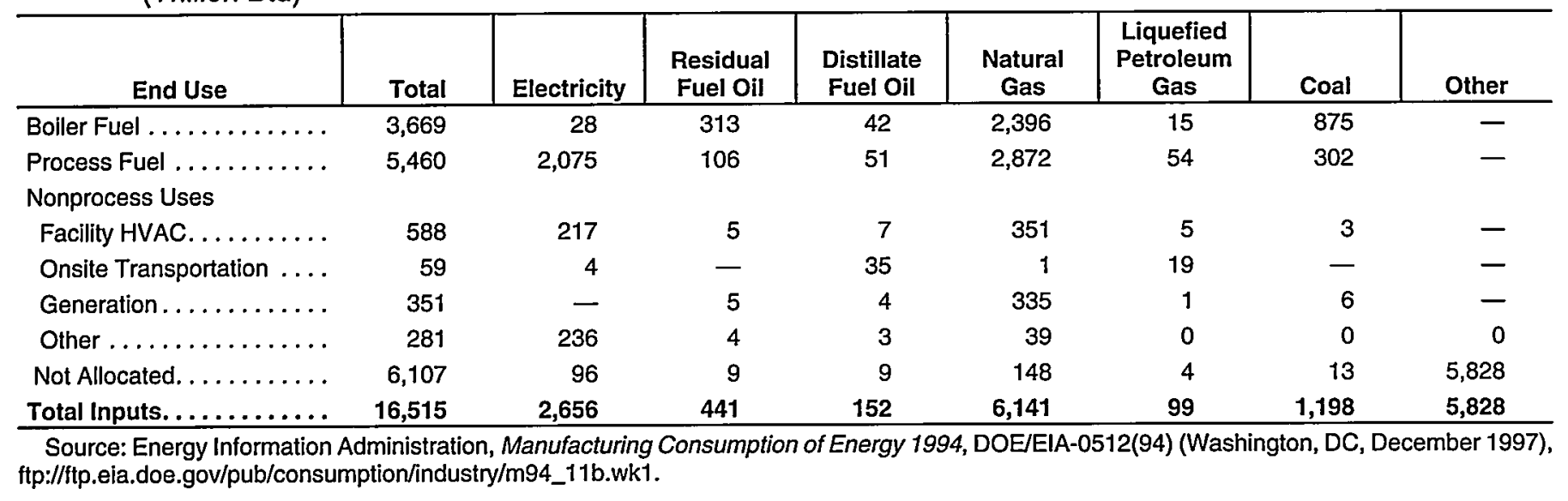

Table 6. Northeast Manufacturing Energy Consumption, 1994 (Trillion Btu)

\begin{tabular}{|c|c|c|c|c|c|c|c|c|}
\hline $\begin{array}{r}\text { End Use } \\
\end{array}$ & Total & Electricity & $\begin{array}{c}\text { Residual } \\
\text { Fuel Oil }\end{array}$ & $\begin{array}{c}\text { Distillate } \\
\text { Fuel Oil }\end{array}$ & $\begin{array}{c}\text { Natural } \\
\text { Gas }\end{array}$ & $\begin{array}{c}\text { Liquefied } \\
\text { Petroleum } \\
\text { Gas }\end{array}$ & Coal & Other \\
\hline Boiler Fuel . . . . . . . . . . . . . & 407 & 2 & 119 & 15 & 174 & 2 & 95 & - \\
\hline Process Fuel . . . . . . . . . & 566 & 236 & 25 & 13 & 250 & 11 & 31 & - \\
\hline \multicolumn{9}{|l|}{ Nonprocess Uses } \\
\hline Facility HVAC. . . . . . . . & 97 & 31 & 3 & 5 & 57 & 1 & $\star$ & - \\
\hline Onsite Transportation .... & 8 & 1 & - & 4 & * & 3 & - & - \\
\hline Generation ........... & 13 & 一 & $W$ & 1 & 12 & $W$ & $\star$ & - \\
\hline Other $\ldots \ldots \ldots \ldots \ldots$ & 47 & 37 & 4 & 1 & 5 & 0 & 0 & - \\
\hline Not Allocated. .......... & 487 & 14 & 2 & 3 & 18 & 1 & 3 & 446 \\
\hline Total Inputs. . . . . . . . . . . . & 1,626 & 321 & 153 & 41 & 517 & 18 & 130 & 446 \\
\hline
\end{tabular}

"Less than 0.5 trillion Btu.

$W=$ Withheld to avoid disclosure of individual establishment data.

Source: Energy Information Administration, Manufacturing Consumption of Energy 1994, DOE/EIA-0512(94)(Washington, DC, December 1997), $\mathrm{ftp}: / / \mathrm{ttp}$.eia.doe.gov/pub/consumption/industry/m94_11b.wk1. 
Northeast, with 5 trillion Btu of distillate fuel oil used for facility HVAC, accounted for 70 percent of the distillate fuel oil consumed for this purpose at all U.S. manufacturing sites.

Some portion of the distillate fuel oil consumed in the manufacturing sector-primarily, the boiler fuel usage-can be switched to other fuels, such as natural gas. Switching may involve the use of dual-fired boilers, changes in utilization rates, or the activation of standby boilers. In 1994, 27 trillion Btu of the total 152 trillion Btu of U.S. manufacturing use of distillate fuel oil (18 percent) could be switched within 30 days to other fuels, including 20 trillion Btu that could be switched to natural gas, 45 and the remainder to other fuels like coal, electricity or residual fuel oil. In the Northeast, 10 trillion Btu of the total 41 trillion Btu of manufacturing distillate fuel oil use ( 24 percent) could be switched to other fuels, including 8 trillion Btu that could be switched to natural gas (Figure 25). Except for planned seasonal variation, there is little economic reason to switch to distillate fuel oil, because its price tends to be significantly higher than the price of natural gas. The gas price tends to be lower because the dual-fuel switchable candidates in the industrial sector use interruptible gas contracts or purchase delivered gas during off-peak periods. Residential customers must pay undiscounted rates. In the

\section{Figure 25. Potential Switching Capability from Distillate Fuel Oil Use in the Northeast Manufacturing Segment, 1994}

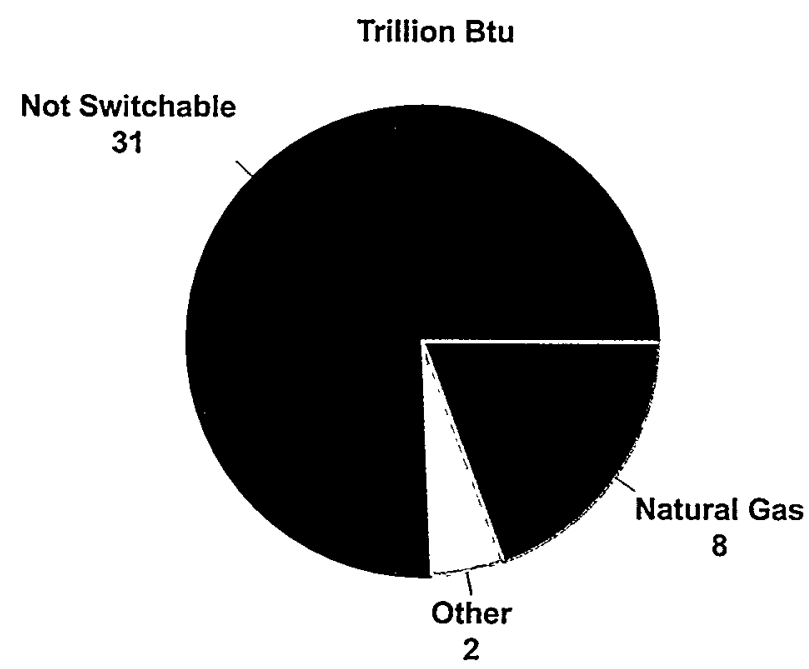

Source: Energy Information Administration, Manufacturing Consumption of Energy 1994, DOE/EIA-0512(94) (Washington, DC December 1997).
Northeast, distillate fuel oil averaged $\$ 5.44$ per million Btu and natural gas averaged $\$ 4.09$ per million Btu in 1997.46

From the manufacturing share of total industrial distillate fuel oil consumption and the percentage of manufacturing distillate fuel oil that is switchable, the potential maximum amount of distillate fuel oil that could be switched can be calculated. The manufacturing share of total U.S. industrial distillate fuel oil use in 1994 was 35 percent (Table 4), and the switchable fraction was 18 percent. This implies that the maximum switchable fraction of U.S. industrial distillate fuel oil consumption was 6 percent.

In the Northeast, the manufacturing share of industrial distillate fuel oil consumption in 1994 was higher, at 48 percent (Table 4), as was the switchable fraction, at 24 percent. Those numbers imply that the maximum switchable fraction of total industrial distillate fuel oil use in the Northeast was 12 percent in 1994. In 1997, industrial distillate fuel oil consumption in the Northeast was 79 trillion Btu (13.6 million barrels). Consequently, the maximum switchable amount of distillate was approximately 9 trillion Btu or about 1.6 million barrels. In comparison, overall distillate fuel oil consumption in the Northeast was 1,540 trillion Btu in 1997. Therefore, at most 0.5 percent of distillate fuel oil consumption in the Northeast could be freed up if the switchable industrial fuel market did not use any distillate fuel oil. If all of that potential reduction occurred during the coldest 2-week period of the winter-an unlikely event-then the increased supply of distillate fuel oil might have a moderating effect on distillate fuel oil prices. In a period of increasing differences between distillate fuel oil and natural gas prices, the industrial sector is likely to react by switching fuels to the extent possible; however, contractual arrangements that limit natural gas consumption in some situations (e.g., service that may be interrupted or curtailed at preset temperature cutoffs in exchange for lower service costs) would reduce the actual switching potential to something less than the maximum switching capability.

\section{Projections to 2005}

The $A E O 2000$ projections can be used to assess the sensitivity of industrial demand to alternative energy prices. In the reference case, industrial distillate fuel oil consumption in the Northeast is projected to increase by 1.1 percent per year from 1997 to 2005. In the high world oil price case, industrial distillate fuel oil prices are about 10 percent higher than in the reference case, and in the low

\footnotetext{
${ }^{45}$ The MECS94 fuel-switching tables give the maximum amount of distillate fuel oil that could be switched to a given other fuel. The sum of the individual quantities exceeds the amount of switchable distillate fuel oil. The calculations in the text subtract the maximum amount that could be switched to natural gas from the amount of switchable distillate fuel oil to impute the quantities for the other fuels (coal, electricity, residual fuel, etc.).

${ }^{46}$ Calculated from AEO2000 Supplement Tables 1, 2,11, and 12. See web site www.eia.doe.gov/oiaf/aeo/supplement/index.html.
} 
Figure 26. Maximum Potential for Industrial Sector Switching From Distillate Fuel Oil Use in the Northeast and Projected Switching Under High World Oil Price Assumptions, 2000-2005

Trillion Btu Change From Reference Case

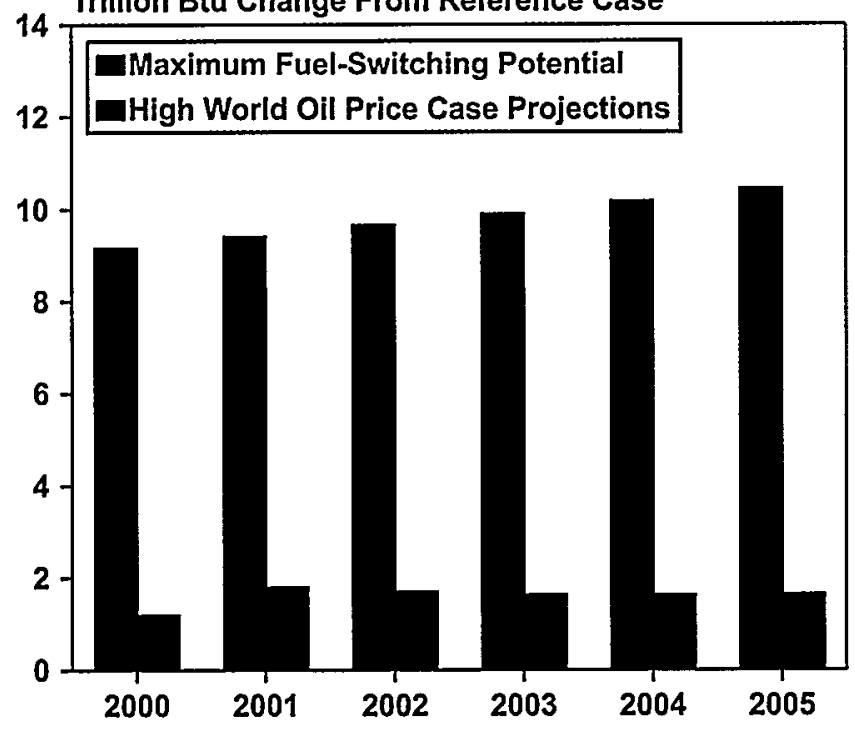

Sources: Energy Information Administration, Manufacturing Consumption of Energy 1994, DOE/EIA-0512(94) (Washington, DC December 1997), and Annual Energy Outlook 2000, DOE/EIA-0383(2000) (Washington, DC, December 1999).

world oil price case results they are about 17 percent lower than in the reference case. In the high world oil price case, industrial distillate fuel oil consumption is projected to be 2 percent (about 2 trillion Btu) less than in the reference case. As noted earlier, the maximum switchable percentage in the Northeast is 12 percent of total industrial distillate fuel oil consumption. Figure 26 compares the maximum switchable amount (10 trillion Btu or 1.7 million barrels in 2005) with the amount that is projected to be switched as result of a 10-percent increase in the price of distillate fuel oil (about 2 trillion Btu or 0.34 million barrels).

\section{Conservation Options}

There is limited additional conservation potential in the industrial sector. Industrial distillate fuel oil consumption per unit of output fell by 40 percent from 1980 to 1997.47 In 1997, industrial distillate fuel oil energy intensity was 0.28 thousand Btu per dollar of output, while industrial total delivered energy intensity was 6.81 thousand Btu per dollar of output. In the manufacturing component of industrial demand, distillate fuel oil is used mainly as a boiler fuel. Little, if any, additional boiler capacity designed primarily to consume distillate is likely to be built. Maintenance of existing distillate capability to facilitate seasonal fuel switching is likely to continue; however, most industrial distillate consumption is in the nonmanufacturing segment, where it is used as motor fuel in farm and construction equipment. This equipment becomes more fuel efficient over time, but fuel consumption is strongly related to the precise type of agricultural or construction activity being undertaken. Further, because peak agriculture and construction activities do not occur in the winter, additional fuel conservation in these activities is unlikely to make available significant additional quantities of distillate at times of high residential demand.

In the Northeast, the pulp and paper industry consumed 54 trillion Btu of pulping liquor and 30 trillion Btu of other biomass residues during 1994. This industry consumed 2 trillion Btu of distillate fuel oil, and its total energy consumption was 305 trillion Btu in the region during 1994. The lumber industry consumed 12 trillion Btu of biomass and 1 trillion Btu of distillate, and its total energy consumption was 22 trillion Btu in the region during 1994. Little, if any, additional pulping liquor or biomass residues would be available for short-term fuel switching.

\section{Other Options Cutting Across All Sectors}

In addition to the flexibility available through current fuel-switching capabilities, additional flexibility can be developed over the next 5 years through incremental consumer investments that can further reduce dependence on home heating oil. Two kinds of investment can be made: those that enhance the efficiency of existing equipment and buildings, and those that replace existing capital stock (or planned additions to stock). Additional new investments over the next 5 years are expected in the Northeast, including electricity generation investments that could result in greater use of alternate fuels and greater electricity generation efficiency, pipeline and distribution investments that could provide greater access to natural gas for end users, and investments in new industrial and building equipment.

The efficiency of existing stock that has not already been upgraded can sometimes be increased through maintenance efforts, such as insulating steam pipes or installing a more efficient burner head in a boiler. Even where the efficiency improvements are not to oil-burning equipment, increases in the efficiency of electricity production from other fuels may reduce some of the pressure on distillate fuel oil stocks.

Cutting across all sectors is the potential for growth in distributed energy resources, such as heat or electricity at or near the site of consumption. Distributed energy resources have the potential to relieve electricity transmission bottlenecks and lower the costs of electricity, heating, and cooling services-particularly when the

\footnotetext{
${ }^{47}$ Energy Information Administration, State Energy Data Report 1997, DOE/EIA-0214 (Washington, DC, September 1999).
} 
load is well matched to the optimal operating conditions of the distributed energy source. However, through 2005, distributed energy resources are limited by their economics and operational difficulties in integrating with the electricity grid system.

\section{Electricity Generation Sector Fuel Choice}

\section{Highlights}

- Utility and nonutility generators in the United States, excluding traditional cogenerators, consumed about 32.6 million barrels of distillate fuel oil (190 trillion Btu) in 1998 for nontransportation uses, or 2.6 percent of the Nation's total distillate fuel oil consumption. In the Northeast, 35 trillion Btu or about 6 million barrels of distillate fuel oil was used to generate about 0.5 percent of the region's total electricity generation. However, when weather conditions are severe, causing high demand and natural gas delivery problems (as in December 1989) or high natural gas prices, the impact of electricity generators on the distillate fuel market can be larger.

- Overall, a small amount of oil is used in the production of electricity today, and its use is expected to decline further.

- Of the oil that is used, the vast majority is residual fuel oil rather than the distillate fuel oil that can be used by consumers to heat their homes.

- Even in the Northeast, where oil use in electricity production is more important than in the rest of the country, about 0.5 percent of the power generated annually comes from distillate fuel oil.

- If distillate fuel oil were unavailable, power companies would most likely turn to natural gas as the replacement fuel.

- Other options could include increasing imports from outside the region, instituting demand management programs in the winter, and improving distillate fuel oil purchasing and storage practices to reduce the possibility that power companies will be buying it when consumers need it for home heating.

\section{Recent Trends in Oil Use for Electricity Generation}

The majority of the electricity produced in the United States is generated from coal, followed by nuclear, natural gas, and hydroelectric power. Generation from these four fuels accounted for more than 94 percent of total
U.S. electricity generation in $1998^{48}$ (52 percent coal, 19 percent nuclear, 15 percent natural gas, 9 percent hydropower) (see Appendix D). Other fuels, such as oil and nonhydroelectric renewables, played a very small role. The vast majority of oil used for electricity generation was, and continues to be, residual fuel oil, not distillate. In the Northeast, oil-based generation was somewhat greater than hydropower (Figure 27).

In 1998, oil accounted for less than 3.4 percent of total U.S. electricity generation. The role played by oil has declined substantially since the mid-1970s and early 1980s (Figure 28). In the 1980s, electricity generation from coal and nuclear (and later in the decade natural gas) increased to meet the increasing demand for electricity and to displace oil-based generation. The move away from oil-based generation was based on several factors, including the changing economics and reliability of coal supply for generation, the nervousness created in the market by the oil shocks of the 1970s, improvements in the national gas supply infrastructure, and the increasing economic competitiveness and perceived reliability of gas supply and generation technologies. In 1980 the share of total electricity generation produced from oil was just under 11 percent, but it has dropped almost continuously since then. The share of generation coming from oil for utility and nonutility generators differs only slightly. In 1998, oil accounted for only 2.6 percent of utility generation and 4.1 percent of nonutility generation.

The share of U.S. electricity generation coming from distillate fuel oil ${ }^{49}$ - the type of oil used by consumers to

\section{Figure 27. Electricity Generation by Fuel in the Northeast, 1998}

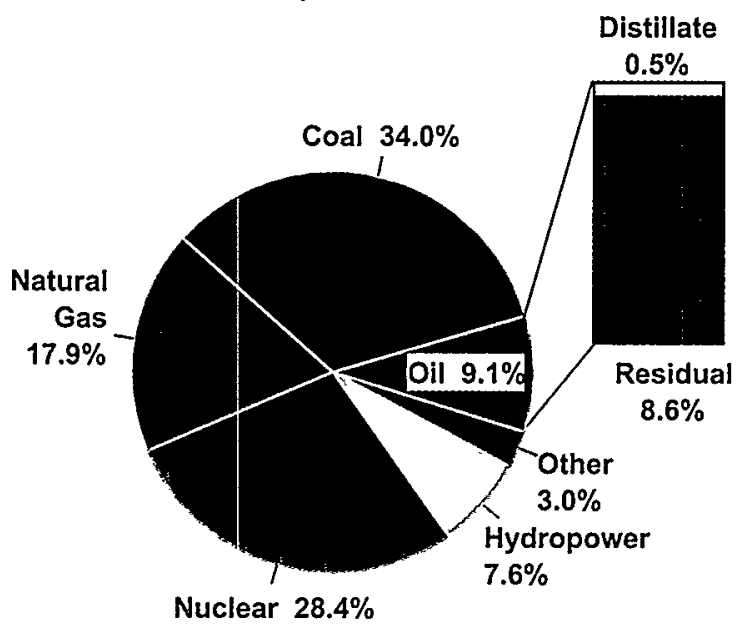

Sources: Energy Information Administration, Form EIA-759, "Monthly Power Plant Report"; Form EIA-860B, "Annual Electric Generator Report-Nonutility"; and Form EIA-867, "Annual Nonutility Power Producer Report."

\footnotetext{
481998 is the last year for which both utility and nonutility generator data are finalized.

${ }^{49}$ Distillate fuel oil used for electricity generation is also referred to as "light oil."
} 


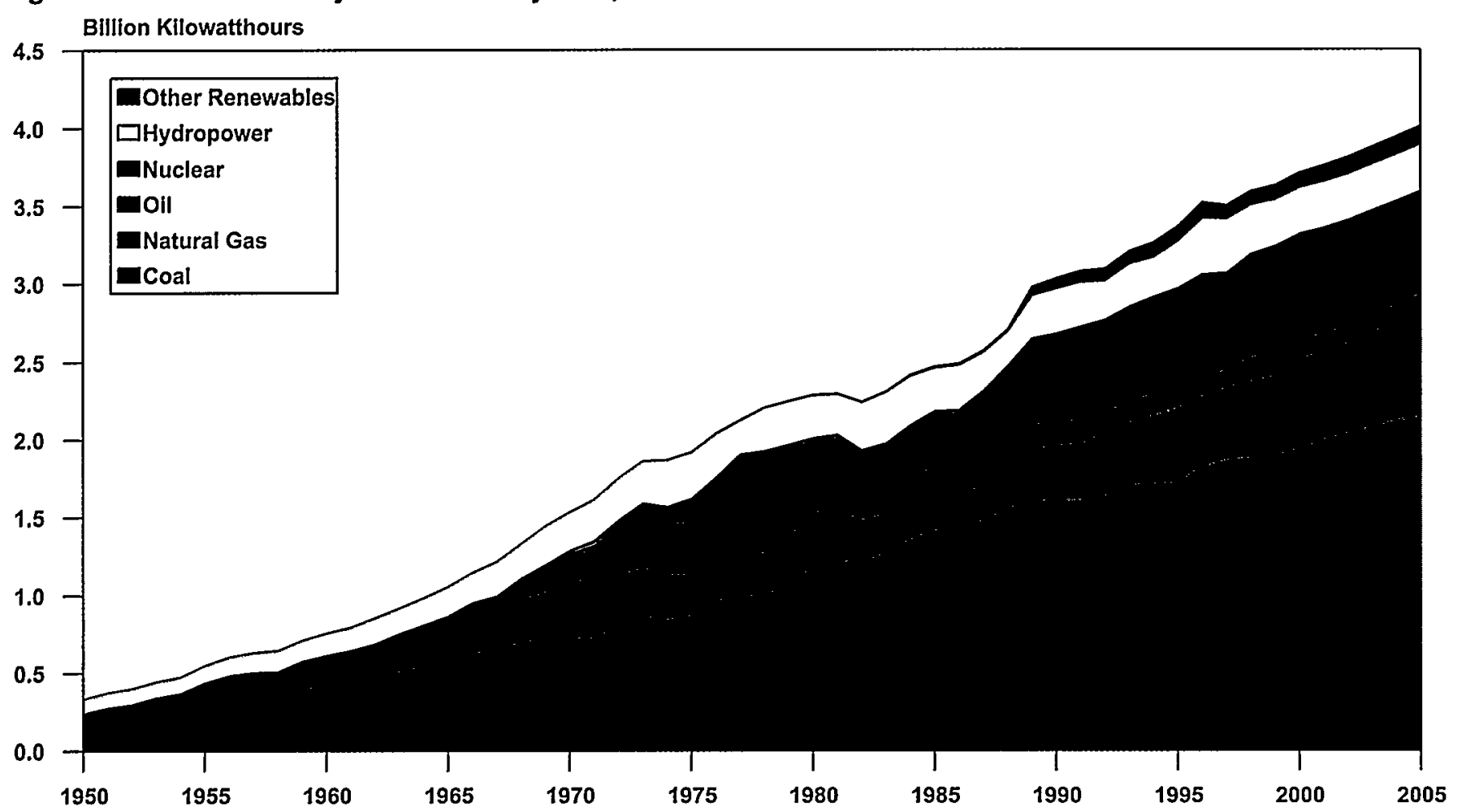

Sources: History: Energy Information Administration, Form ElA-759, "Monthly Power Plant Report"; Form EIA-860B, “Annual Electric Generator Report-Nonutility"; and Form EIA-867, "Annual Nonutility Power Producer Report." Projections: Energy Information Administration, Annual Energy Outlook 2000, DOE/EIA-0383(2000) (Washington, DC, December 1999).

heat their homes-is much smaller. The vast majority of the oil used by power plants is residual fuel oil. For utilities, only 0.3 percent of total generation came from distillate fuel oil in 1998 and 1999, down from 0.6 percent in 1980. The trend for nonutility generators is similar. Nonutility generators do not report their distillate fuel oil generation directly, but their fuel consumption data for 1998 show that only 20 percent of the oil they consumed was distillate fuel oil (see Appendix D). As a result, their generation from distillate fuel oil is approximately 0.6 percent of their total generation.

Distillate fuel oil is not economically competitive with other available generation fuels. Typically, it is used in small amounts in steam plants for flame control and in relatively inefficient combustion turbines and internal combustion engines when the demand for electricity is high and other fuels are unavailable to generate it. Such plants tend to be run intermittently and are not good investment opportunities for natural gas suppliers or pipeline developers. Distillate fuel oil can be used in many of the new turbines and combined-cycle plants in the construction pipeline, but the relative price and environmental advantages of gas are expected to make natural gas the fuel of choice in almost all cases. For example, in 1998, with very low overall oil prices, distillate fuel oil delivered to power plants cost $\$ 3.19$ per million Btu, but natural gas was much less expensive at $\$ 2.34$ per million Btu. Over the next 5 years, the price gap is expected to persist and could widen.

Total U.S. utility consumption of distillate fuel oil in 1998 was just over 22.0 million barrels (128 trillion Btu) (see Appendix D), or 1.6 percent of total distillate fuel oil consumption. For nonutility generators, distillate fuel oil consumption totaled 10.5 million barrels (61 trillion Btu) in 1998 (1998 is the last year for which nonutility generator data are available). ${ }^{50}$ Utility and nonutility generators together consumed 32.6 million barrels (190 trillion Btu) of distillate fuel oil in 1998, or 2.6 percent of total distillate fuel oil consumption.

The use of oil in the electricity generation sector varies by region of the country (Figure 29 and Appendix D). The largest quantity of oil is used in Census division 5, the South Atlantic. ${ }^{51}$ In terms of the share of generation, however, Census division 1, New England, is by far the highest with a 24-percent share in 1998. Other than Census division 1, only divisions 5 and 2 produced more than 5 percent of their generation from oil. Each of these

\footnotetext{
${ }^{50}$ Nonutility generator consumption data include data for cogenerators, small power producers, and independent power producers. Some of this consumption is typically reported in the industrial sector.

${ }^{51}$ Includes Delaware, Maryland, the District of Columbia, Virginia, West Virginia, North Carolina, South Carolina, Georgia, and Florida.
} 
Figure 29. Electricity Generation from Oil and from All Other Fuels by Census Division, 1998

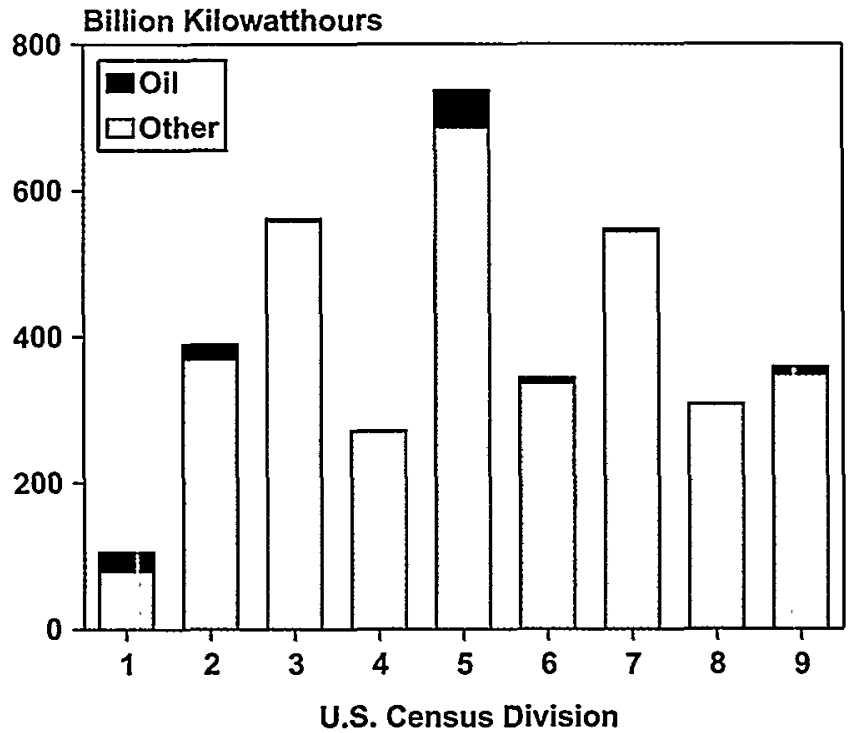

Note: U.S. Census divisions: $1=$ New England (CT, ME, MA, $\mathrm{NH}, \mathrm{RI}, \mathrm{VT}) ; 2$ = Middle Atlantic (NJ, NY, PA); 3 = East North Central (IL, IN, Ml, OH, WI); 4 = West North Central (IA, KS, MN, MO, NE, ND, SD); 5 = South Atlantic (DE, DC, FL, GA, MD, NC, SC, VA, WV); 6 = East South Central (AL, KY, MS, TN); $7=$ West South Central (AR, LA, OK, TX); $8=$ Mountain (AZ, CO, ID, MN, NV, NM, UT, WY); 9 = Pacific Contiguous (CA, OR, WA); $10=$ Pacific Noncontiguous (AK, HI).

Sources: Energy Information Administration, Form ElA-759, "Monthly Power Plant Report"; and Form EIA-860B, "Annual Electric Generator Report-Nonutility."

regions relies more heavily on older oil and gas steam plants than do other regions. In the Midwest region (Census division 3), the region just to the west of the Northeast, the share of generation coming from oil was only 0.6 percent in 1998.

In all U.S. regions, the vast majority of the oil used for electricity generation is residual fuel oil rather than distillate fuel oil (Figure 30). In the Northeast (the combination of Census divisions 1 and 2 in this report), only 6 percent of the total generation from oil comes from distillate fuel oil. If all the distillate fuel oil used to produce electricity in the Northeast were shifted to some other fuel, distillate fuel oil consumption would be reduced by 6.1 million barrels ( 35 trillion Btu), an average daily reduction of just 17,000 barrels per day ( 0.1 trillion Btu). More important, however, is the amount of distillate fuel oil consumed during the peak winter months of December through February, when distillate fuel oil pricing is an issue. For example, December 1989 saw record distillate fuel oil consumption levels for electricity generators in the Northeast, reaching 77,000 barrels per day. Such short-term, rapid changes in demand can cause rapid and significant price changes.
Figure 30. Utility and Nonutility Generator Oil Consumption by Census Division, 1998

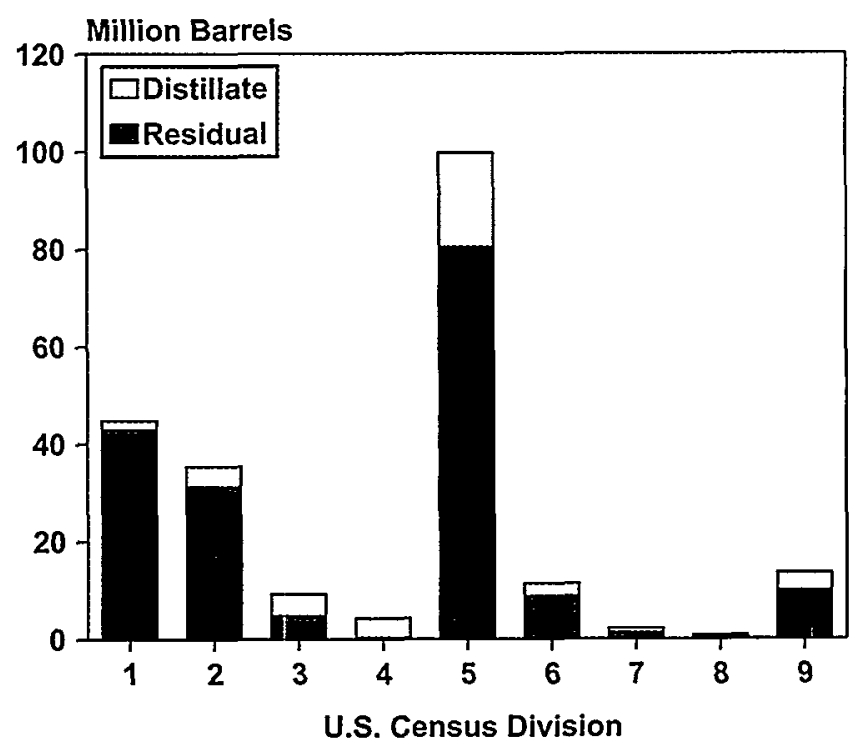

Note: U.S. Census divisions: 1 = New England (CT, ME, MA, $\mathrm{NH}, \mathrm{RI}, \mathrm{VT}$ ); 2 = Middle Atlantic (NJ, NY, PA); 3 = East North Central (IL, IN, MI, OH, WI); 4 = West North Central (IA, KS, MN, MO, NE, ND, SD); 5 = South Atlantic (DE, DC, FL, GA, MD, NC, SC, VA, WV); 6 = East South Central (AL, KY, MS, TN); $7=$ West South Central (AR, LA, OK, TX); $8=$ Mountain (AZ, CO, ID, MN, NV, NM, UT, WY); 9 = Pacific Contiguous (CA, OR, WA); 10 = Pacific Noncontiguous (AK, HI).

Sources: Energy Information Administration, Form EIA-759, "Monthly Power Plant Report"; and Form ElA-860B, "Annual Electric Generator Report-Nonutility."

Although the use of distillate fuel oil for electricity generation is relatively limited on an annual basis, seasonal variations in use can influence the prices paid by heating oil consumers. In most years, the use of distillate fuel oil for electricity generation peaks in summer, when consumers' need for power is greatest. In extremely cold winters, however, distillate fuel oil use for generation can also rise, as occurred in December 1989 (Figure 31). In a typical year, distillate fuel oil consumption in the electricity generation sector in the Northeast average approximately 17,000 barrels per day; however, in December 1989 it averaged nearly 77,000 barrels per day. Average temperatures in December 1989 were much colder than normal. In the North, the colderthan-normal month significantly increased the demand for natural gas by firm service customers (primarily in the residential and commercial markets). In the gas-producing regions of the South, unusually cold temperatures caused some wells to freeze, reducing production during the period of critically high demand, particularly in the Northeast. Gas prices rose sharply as a result, and significant numbers of industrial and electricity generation customers were forced to switch fuels, mostly to residual and distillate fuel oil. 
Figure 31. Electric Utility Generation from Distillate Fuel Oil by Census Division and Month, 1989

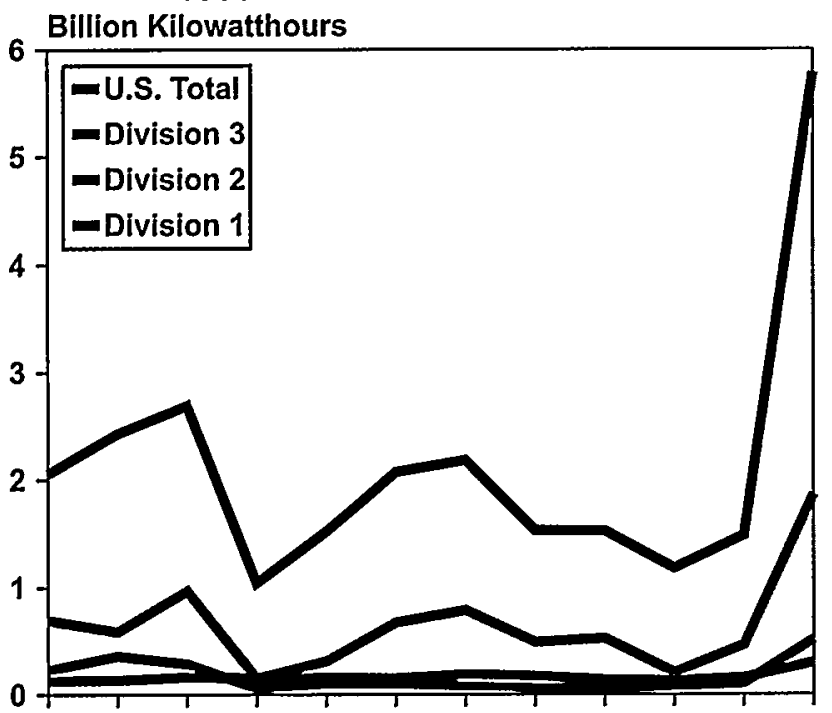

Jan Feb Mar Apr May Jun Jul Aug Sep Oct Nov Dec

Note: U.S. Census divisions: $1=$ New England (CT, ME, MA, $\mathrm{NH}, \mathrm{RI}, \mathrm{VT}) ; 2$ = Middle Atlantic (NJ, NY, PA); 3 = East North Central (IL, IN, MI, OH, WI).

Source: Energy Information Administration, Form EIA-759, "Monthly Power Plant Report."

In 1989 , at the national level, nearly 23 percent of the annual utility use of distillate fuel oil ful oil occurred in December. The winter increase in usage was even more pronounced in Census division 1 (New England) where more than 25 percent of the annual utility use occurred in December. Still, distillate fuel oil accounted for only 0.4 percent of total utility generation nationally in 1989 and only 1.3 percent in New England. In December 1989, distillate fuel oil accounted for 2.8 percent of total utility generation in New England.

In terms of the overall distillate fuel oil market in the Northeast, the electricity generation sector is a relatively small player. On an annual basis, electricity generation accounts for only 2 to 3 percent of the region's total market for distillate fuel oil (excluding transportation uses). However, when weather conditions are severe and natural gas is unavailable or expensive, the use of distillate fuel oil for electricity generation can be more important. In 1989, with a very cold winter, the electricity generation share of annual distillate use in the Northeast was nearly 5 percent, and in December 1989, 24 percent of electric utility generation was from distillate fuel oil. As mentioned above, electric utility consumption of distillate fuel oil in December 1989 averaged 77,000 barrels per day, much higher than the typical yearly average of 17,000 barrels per day. ${ }^{52}$
In the future, oil is expected to play a comparatively minor and decreasing role in the U.S. electricity generation sector. In $A E O 2000$, generation from oil is projected to account for less than 2 percent of total generation by 2005 and less than 1 percent by 2020. Existing oil-fired generators are expected to be used less, and some are expected to be retired. In addition, new natural-gasfired combustion turbines and combined-cycle plants are expected to account for more than 90 percent of new capacity additions. As the new plants are built, they will be used not only to meet growing demand but also to displace the generation from older oil-fired plants-particularly in regions like the Northeast that currently use relatively large amounts of oil for electricity generation.

If oil prices were much lower than expected, as in the AEO2000 low world oil price case $(\$ 14.90$ per barrel in 2020), the share of generation from oil could stay near the current level of 3 to 4 percent of total generation. Although no new oil-fired plants would be built, existing oil plants would continue to be used. Still, however, the vast majority of the oil used would be residual fuel oil (heavy oil) rather than distillate fuel oil (light oil).

\section{Projections to 2005}

Over the next few years the use of oil for electricity generation is expected to continue to fall. New oil plants are simply not economically competitive with other options, and the utilization of existing plants is expected to decline as new gas-fired plants are added to meet demand growth. The older oil and gas steam plants in the Northeast are expected to be prime candidates for retirement as new, more efficient plants are brought on line. In the $A E O 2000$ reference case, approximately 20 percent (4 gigawatts) of the existing oil and gas steam capacity in the Northeast (here defined as the combination of the New York and New England power pools) is expected to be retired by 2005 . As a result, the share of generation from oil declines from just over 2.4 percent in 2000 to 1.7 percent by 2005 at the national level and from 13.2 percent to 10.8 percent in the more oil-intensive Northeast (Figure 32). As mentioned above, the share of generation from distillate fuel oil remains well below 1 percent in all years. As new turbine-based systems (simple combustion turbines and combined-cycle plants) are added, it is possible that they could turn to distillate fuel oil when gas is not available. Most of the new gas plants are expected to be heavily utilized, making it economically attractive to develop the gas infrastructure needed to meet their needs.

${ }^{52}$ The 1989 values are for utilities only. Monthly data for nonutility generator consumption in 1989 are not available. 
Figure 32. Projected Oil Shares of Electricity Generation in the Northeast, 2000-2005

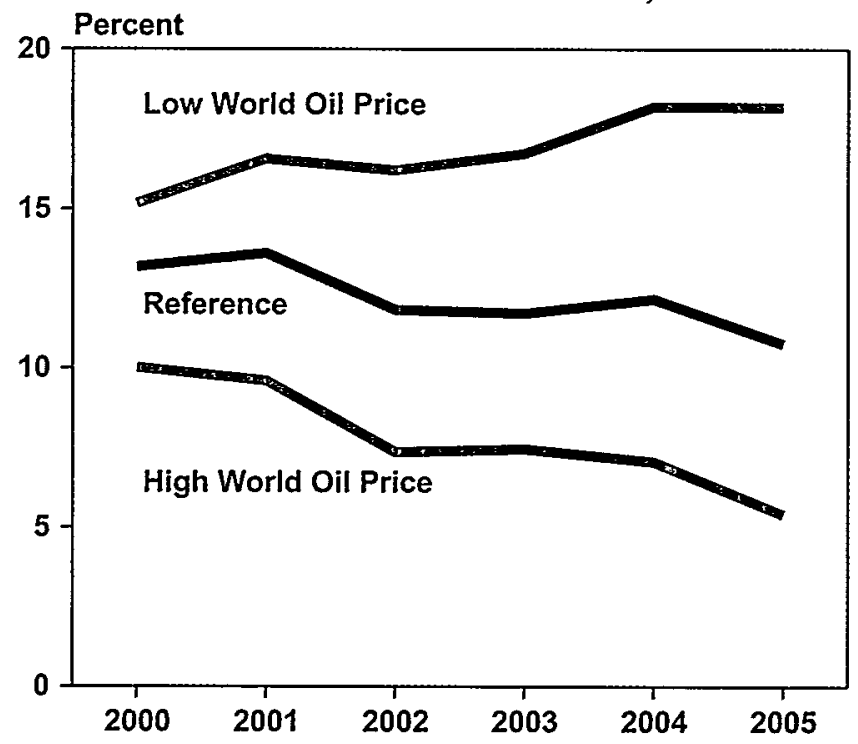

Source: Energy Information Administration, Annual Energy Outlook 2000, DOE/EIA-0383(2000) (Washington, DC, December 1999).

\section{Fuel Supply Options for Electricity Generators}

Electricity generators in the Northeast (both utilities and nonutilities) using natural gas as their primary fuel have been reluctant to commit contractually to firm (365-day) gas service because of the high transportation costs for such service. As an alternative, a power generator might buy natural gas on the interruptible market and either build a short-duration storage facility for distillate (or residual) fuel oil or shut down the generator when gas service is actually interrupted and either dispatch another plant or import power from an adjacent region. Another alternative might be to contract for a variety of semi-firm services (for up to 365 days) but allow a local gas distribution company the right to call on the gas for a specified number of days. Because the winters have been warm for most of the past 20 years, interruptible gas service has effectively turned into firm service without the higher costs. There is little incentive under these circumstances for generators to commit to costlier firm service options. Recent anecdotes suggest that the reliability of natural gas supply and the added cost of carrying a full inventory of distillate fuel oil or residual fuel oil (which has often remained unneeded) have tempted some electricity generators not to maintain adequate inventories of replacement fuel in storage through the winter. If so, their need to buy oil supplies on the spot market when gas supplies were interrupted may have contributed to this year's distillate fuel oil price surge.
Possibilities for reducing the use of distillate fuel oil by electricity generators in the Northeast include increasing interregional transmission capacity and building new generating capacity to displace existing capacity. Given the high costs and long lead times involved in natural gas pipeline capacity expansion projects, that option may not be economical. New natural-gas-fired generating plants can be brought on line in 1 to 2 years, and many are already planned. Other new capacity options (coal, wind, biomass, and solar) are much less economical and normally take longer to bring on line. In addition, because wind and solar plants are not dispatchable, ${ }^{53}$ they are not likely to be good substitutes for plants that use distillate fuel oil.

In $A E O 2000$, the levelized cost for new plants in 2005 averages 3.5 cents per kilowatthour for gas combined cycle, 4.1 cents per kilowatthour for coal, 5.9 cents per kilowatthour for wind, 7.0 cents per kilowathour for nuclear, and 20.2 cents per kilowatthour for solar photovoltaic. In addition, because wind and solar generating plants are not dispatchable, they may not be good substitutes for plants that use distillate fuel oil. Although new nuclear power plants are currently too costly to compete with either coal or natural gas combined-cycle plants, and nuclear construction lead times are too lengthy to have an impact by 2005 , it may be possible to increase the utilization rates of existing nuclear units in the winter period to reduce distillate fuel oil use during the winter months. However, the current utilization rate for nuclear power plants in the Northeast exceeds 80 percent, and the opportunities for significant additional contributions appear to be minimal.

Although not likely to have a notable impact in the near term, over the longer run renewable energy sources could reduce some of the demand for petroleum and other fossil fuels in New England's electricity production. New England is moving to increase the use of renewable sources for electric power, including biomass (such as from wood chips), landfill gas from municipal solid waste, solar power (both solar photovoltaics for direct electricity production and solar thermal water heating to reduce electricity demand), and wind. Connecticut, Maine, and Massachusetts all have enacted renewable portfolio standard (RPS) programs requiring increased use of renewable energy sources after 2000. Massachusetts and Rhode Island have "green power" programs allowing customers willing to pay a premium to purchase electric power generated from new renewable energy sources. A leading-edge biomass gasification-to-electricity facility using wood chips is being tested in Vermont. In addition, most New England States offer tax incentives to encourage renewables and allow consumers to sell unneeded power generated

${ }^{53}$ An electricity generator is "dispatchable" if it can be called on to generate electricity as needed. 
from renewable sources back to their utilities at the same prices the utilities charge them for retail service (referred to as "net metering"). Use of solar photovoltaics is especially encouraged in order to reduce electric power demands during peak air conditioning times. To the extent that these programs are successful, renewables will be able to reduce New England's dependence on fossil fuels. Nevertheless, because New England is not well endowed with most renewable resources, generating electricity from them is-and will remain-more costly than using fossil fuels in most instances. Therefore, additional renewables will likely remain minor contributors to New England electricity supply well beyond 2005 .

An alternative to reducing distillate fuel oil use, might be to improve the purchasing and storage practices of electricity generators, so that they would not be competing with homeowners when unexpected cold weather strikes. Options for doing this include improving the distillate fuel oil delivery channels to power plants and increasing their storage capacity.

\section{Northeast Distillate Fuel Oil Market Summary}

The estimates of fuel-switching capability in the various end-use sectors described in this chapter are approximations derived from EIA's MECS, CBECS, and electric power survey data for discrete years. The data are also aggregate in nature. Several factors contribute to the uncertainty of the estimate of the size of the dual-fuel market, including the use of data from a survey sample to represent a whole set of establishments and the use of survey data that are not designed to address the specific questions being analyzed here (how consumers make fuel choices, what consumer options are or what they perceive them to be, what the specific capability to use alternate fuels is, etc.). Further, because energy consumption is not measured at the daily or even the weekly level for any fuel, the precise interaction of spot prices with other factors, such as deliverability constraints, fuel consumption, and stock in storage, can only be approximated. Special circumstances, such as the status of equipment that uses other fuels or year 2000 (Y2K) concerns, may determine actual fuel choices in some periods that appear to be inconsistent with cost considerations.

The practical capability to switch year-round distillate-only consumption to different fuels depends on a variety of factors, including the time frame, the rate of physical retirement of equipment, interest rates, equipment and fuel choices and their associated characteristics, and specific performance and reliability requirements (for example, uninterrupted fuel supply
24 hours per day, 7 days per week, may be required, or equipment shutdown may be an acceptable alternative). Typically, large energy-using equipment (such as boilers, heating systems, and generators) is replaced only when it breaks down. Exceptions occur when the energy cost of production has to be brought down to remain competitive or when environmental constraints on effluents or emissions impose a sufficiently large externality cost to warrant retirement.

To take advantage of episodic price differences between fuels, large energy-using establishments usually install a dual-fuel-switching capability, usually between natural gas and either residual fuel oil or distillate fuel oil. If they have not done so, it usually means that conversion from distillate-only equipment is either not economical or not feasible. Most of the fuel-switching capability in the Northeast is between residual fuel oil and natural gas, not distillate fuel oil and natural gas. Figure 33 shows the switching by utilities that took place among natural gas, distillate fuel oil, and residual fuel oil in 1989, when December distillate fuel oil consumption was the highest on record, at about 2.4 million barrels.

\section{Fuel-Switching Potential}

The size of the maximum potential of 1997 distillate fuel oil consumption that could be switched to other fuels in a relatively short time frame can be estimated from information in the preceding sections of this chapter. Considering the estimated maximum potential switchable amounts from the commercial and industrial sectors, and assuming that all utility use of distillate fuel oil in the winter is switchable, a total maximum potential of

Figure 33. Electric Utility Consumption of Distillate Fuel Oil, Residual Fuel Oil, and Natural Gas in the Northeast by Month, 1989

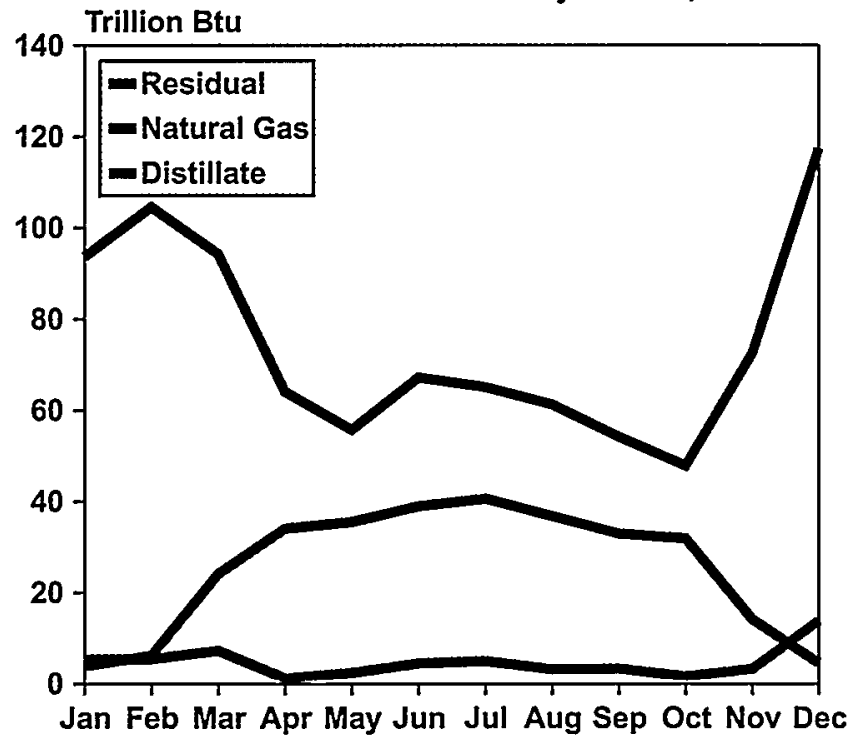

Source: Energy Information Administration, Form EIA-759, "Monthly Power Plant Report." 
Table 7. Northeast Estimated Switchable and Conversion Potential

\begin{tabular}{|c|c|c|c|}
\hline Sector & $\begin{array}{l}\text { Maximum Annual } \\
\text { Switchable Volume } \\
\text { (Million Barrels) }\end{array}$ & $\begin{array}{c}\text { Daily Switchable Volumes If } \\
\text { Consumption Were Restricted to } \\
\text { December-February } \\
\text { (Thousand Barrels per Day) } \\
\end{array}$ & $\begin{array}{c}\text { Conversion Potential If All Distillate } \\
\text { Use by Large Users Were } \\
\text { Converted to a Different Fuel } \\
\text { (Million Barrels) }\end{array}$ \\
\hline Industrial $\ldots \ldots \ldots \ldots \ldots$ & 1.6 & 16 & 6.5 \\
\hline Electricity Generation $^{\mathrm{a}} \ldots \ldots$. & $2.9^{b}$ & $31^{b}$ & 7.1 \\
\hline Total $\ldots \ldots \ldots \ldots \ldots$ & 13.1 & 133 & 33.6 \\
\hline
\end{tabular}

${ }^{2}$ Because usually only one-third of distillate consumption for electricity generation occurs in the winter months (December, January, and February), the consumption shown is the estimated winter use portion, assuming that 40 percent of the year's distillate use might occur in the winter of an unusual year.

Winter only.

Source: Tables in this chapter.

76 trillion Btu (13.1 million barrels per year), or about 5 percent of overall distillate fuel oil consumption in the Northeast in 1997 could be switchable (Table 7). We know, however, that not all utility demand for distillate fuel oil is switchable; that about 1.4 million barrels per month is distillate-only generation; ${ }^{54}$ and that for commercial and industrial applications, most of the switchable demand is likely to occur during the heating season.

The methodology used to estimate the maximum switchable quantities was as follows:

- For the commercial sector, it was assumed that all distillate fuel oil used in a building is switchable (including the fuel oil used for water heating and other uses) if distillate fuel oil was the building's primary heating fuel but it was reported that it could be switched to another fuel. Because applications other than space heating can account for 30 percent or more of a building's distillate fuel consumption, this component of the switchable estimate is likely to be high.

- Second, it was assumed that 90 percent of the heating oil requirements occur in the three contiguous winter months (December, January, and February). Because both November and March also contain substantial heating degree-days, the allocation of 90 percent of the distillate consumption into 90 days also overestimates consumption.

- Finally, because the direction was that we should look only at large-volume users or industrial users for conversion to a different fuel, less than 50 percent of the commercial market would qualify, largely offsetting those natural gas customers who can switch to distillate fuel oil.

The first three factors overestimate the switchable distillate volumes in the commercial sector. The overestimation is intended to compensate for the use of consumption data for 1997, which was a normal year, because we are concerned with years that are as much as 10 percent colder than normal years during the three winter months. For example, if we assume that: (1) only 85 percent of the distillate is consumed in the three coldest months (instead of 90 percent), (2) 90 percent of the switchable distillate use in buildings with reported fuel-switching capability (not the 70 percent implied earlier), (3) distillate consumption in the commercial sector stops declining under normal weather conditions, and (4) there is a 10 percent colder than normal winter in the Northeast, then our estimate of commercial and industrial sector distillate fuel consumption during the three winter months would be overestimated by at least 5 percent, and probably more. The treatment of the industrial sector is similar, with 90 percent of the 9 trillion Btu (1.6 million barrels) defined as switchable allocated to the three winter months.

For the electricity sector, the switchable amount was estimated from a recent normal historical year and then increased by slightly more than 14 percent for 2005 under normal weather conditions. Since the AEO2000 projects declining distillate usage, this overestimates consumption under normal weather conditions. We then applied 40 percent of the total annual consumption to the winter period. Taken together, these adjustments mean that in a severe winter, distillate consumption during a three-month winter period of colder than normal weather could be about 42 percent higher than consumption during a normal winter. The normal distribution of distillate fuel oil use for electricity generation is almost evenly divided between the three periods: summer (June, July, August), winter (December, January and February), and the rest of the year. Under these conditions, distillate fuel oil consumption could increase by about 133 thousand barrels per day or more in the Northeast. The peak-day usage could actually be higher. Whether such short-term increases cause price surges also depends on the duration of distillate fuel oil demand, stock levels, imports, and other production and delivery factors. If such a sharp distillate fuel oil

\footnotetext{
${ }^{54}$ Because natural gas prices are lowest from April through August, any distillate fuel oil consumption during those months can be roughly attributed to increased electricity demand and the inability to burn natural gas-that is, to the use of distillate-only generators.
} 
demand increase occurred during a very cold period and during a severe supply-demand imbalance, the short-term incremental demand could significantly raise what might already be high distillate fuel oil prices to residential customers, as occurred in the winter of 1999-2000.

Northeast distillate fuel oil consumption in the 1990s for utility and independent power producers (see Appendix D) ranged from about 19 trillion Btu (3.3 million barrels) to about 41 trillion Btu (about 7.1 million barrels) annually. Data for 1998, the most current year for which regional utility and nonutility consumption data are available, show the Northeast with about 35 trillion Btu (about 6 million barrels) of distillate fuel oil consumption. Distillate fuel oil consumption for electricity generation could rise as high as 40 trillion Btu by 2005 , or more if large amounts of combined-cycle capacity are added and a cold winter occurs. Peak-month distillate fuel oil consumption was about 2.4 million barrels in December 1989 (about 77,000 barrels per day) and occurred because of the extraordinary gas situation and extreme weather. More normal winter weather would result in peak-month distillate fuel oil consumption of less than 0.6 million barrels or less than 19,000 barrels per day.

The likelihood that all electricity generated from distillate fuel oil use could actually be switched to another fuel is small. Distillate fuel oil is expected to be used by utilities primarily when natural gas is unavailable. Some of the units that burn distillate fuel oil are older, inefficient diesel-fired units that have no pipeline gas access and are used only intermittently. At least 1.4 million barrels per month of such capability exists in the Northeast, and the economics of delivering gas to these relatively small, intermittent users may preclude the possibility of switching them to gas. The rest of the Northeast's distillate fuel oil use for power generation is attributed to dual-fired turbines or combined-cycle units that can use either distillate fuel oil or natural gas. Distillate fuel oil consumption in the winter period averages about
33 percent of the year's total but can rise to 40 percent under unusual circumstances. Northeast distillate fuel oil consumption in the three coldest winter months, when natural gas may not be available, has the greatest potential impact on distillate fuel oil prices. Based on these assumptions, no more than 2.9 million barrels is switchable during the winter months. The maximum estimate of 50 trillion Btu (about 8.6 million barrels) for annual switchable potential in the commercial sector is also optimistic, because it was assumed that consumers who can switch their heating fuel can also switch fuels for all other uses.

\section{Conversion of Distillate Fuel Oil Use to Other Fuels}

If all the distillate fuel oil used for manufacturing and utility purposes in the Northeast were displaced, at most 79 trillion Btu (13.6 million barrels) of distillate fuel oil would be freed for use by residential consumers. Adding all the distillate fuel oil used for heating in the commercial sector raises the total in this extreme case to about 195 trillion Btu (33.6 million barrels) of fuel oil. The manufacturing total includes all uses, ranging from boiler use and direct process use to onsite transportation and facility HVAC uses, some of which are not practical for conversion. In addition, the total includes distillate fuel oil use by manufacturing concerns that reported they could not switch boiler fuels without replacing their existing boilers, an uneconomical decision under the range of distillate fuel oil and natural gas prices considered. The caveats raised in the previous paragraph concerning the commercial and utility potential apply here as well. The complete conversion of distillate fuel oil use to other fuels, particularly to natural gas, is infeasible and probably unnecessary in view of completed or planned natural gas pipeline construction over the next 2 years and the availability of less costly consumer management and price hedging instruments for heating oil customers (see Chapters 4 and 5 of this report). 



\section{Natural Gas Supply, Infrastructure, and Pricing}

\section{Introduction}

One of the goals of this study is to assess the ability of the natural gas infrastructure in the Northeast to support a shift by large-volume users of distillate fuel oil to natural gas. Demand for natural gas tends to be seasonal, and the infrastructure is designed and operated primarily to meet the need for firm service. The additional demand that would result from a shift of large-volume distillate users to gas would require an increase in gas deliveries to the Northeast. ${ }^{55}$ More importantly, the new customers would require firm service throughout peak demand periods, to avoid the risk of adding demand to the oil market when conditions are tight. To provide the additional service, capacity expansions would be needed across the delivery system, with emphasis on ensuring physical deliverability even when demand in the region and the load on the gas infrastructure are at peak levels.

Natural gas consumption requirements in the Northeast are met through the combined operation of the three

Figure 34. Average Monthly Natural Gas Consumption in the Northeast by Sector, 1989-1998

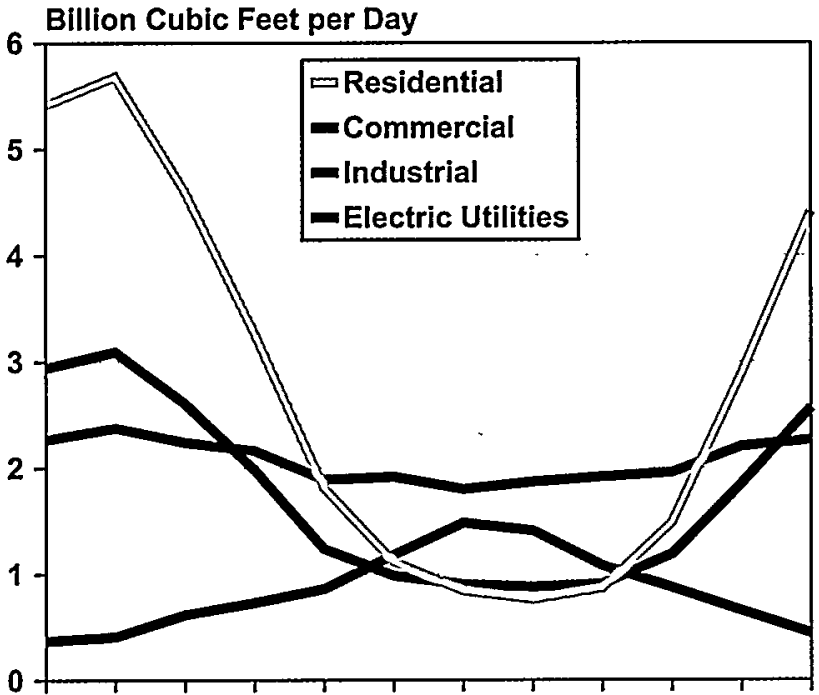

Jan Feb Mar Apr May Jun Jul Aug Sep Oct Nov Dec

Source: Energy Information Administration (EIA), Oil and Gas Information Retrieval System (OGIRS) (February 2000). major components of the gas supply chain: transportation, storage, and distribution. Transportation generally refers to long-distance shipment of natural gas, primarily in interstate commerce. Storage generally refers to three methods of storing gas for later delivery: underground storage of large volumes of natural gas in depleted oil and gas reservoirs, and two "peak shaving" options for storing smaller volumes of liquefied natural gas (LNG) ${ }^{56}$ or propane. Distribution refers to operations associated with the local delivery of gas, primarily to end users. Distribution, provided by local distribution companies (LDCs) within the borders of each State to deliver gas to customers at the burnertip, falls under the jurisdiction of State authorities. Transportation falls under Federal jurisdiction when it involves interstate commerce, or under State jurisdiction if the transportation service provider operates wholly within the borders of one State.

\section{Current Status of the Natural Gas Industry in the Northeast}

\section{Consumption}

Although natural gas can be stored in the vicinity of major consumption markets, consumption by end users in U.S. markets generally occurs on a "just-in-time" basis, with most customers drawing supplies from the system as needed. With limited capability for on-site storage at customer locations, the system must meet customer requirements under a wide range of operating conditions. In the Northeast, seasonal patterns of gas consumption vary among the end-use sectors (Figure 34). For the residential and commercial sectors, average daily volumes peak in the months of the heating season and fall to yearly lows in the summer months. Average daily demand in the residential sector during February is more than 7 times the average during August. For electric utilities the pattern is reversed, with peak demands during the summer air-conditioning season (when demand for electricity peaks and even the most inefficient turbines are brought into service) and lows during the winter heating season. In the future, as more intermediate and base electric load is served by natural gas, the proportion of winter usage is expected to rise,

\footnotetext{
${ }^{55}$ In the discussion of natural gas supply, the Northeast consists of the New England Census division (Connecticut, Massachusetts, Maine, New Hampshire, Rhode Island, and Vermont) and the Middle Atlantic Census division (New Jersey, New York, and Pennsylvania).

${ }^{56}$ LNG is natural gas converted to a liquid state by cooling to $-260^{\circ} \mathrm{F}\left(-162^{\circ} \mathrm{C}\right)$. The transformation reduces volume by a factor of 600 to 1 , which makes it a useful storage option. The ability to regasify LNG rapidly makes it especially suitable as a source of gas supply to satisfy peak demand.
} 
although not as high as in the summer. The seasonal pattern for industrial demand is similar to that for the residential and commercial sectors, but with much smaller shifts between the high and low points.

\section{Supply}

Sources of gas in the Northeast are production, imports, pipeline transportation, and storage withdrawals. Production of natural gas in the Northeast is limited to relatively small volumes in States in the Middle Atlantic region, where 1998 production was less than 4 percent of the total volume delivered to end users in the Middle Atlantic and less than 3 percent of the total delivered to end users in the Northeast as a whole..$^{57}$ The Northeast received 71 percent of current supply 58 in 1998 from net inflows from other U.S. regions, 24 percent from pipeline imports, and 2 percent from LNG imports. In New England, 89 percent of current supply was obtained from the domestic transportation network. ${ }^{59}$ Although LNG is a small part of total regional supply, it is significant in New England. LNG made up 11 percent of New England supplies in 1998, and LNG volumes more than doubled in 1999 ( 96 billion cubic feet, compared with 43 billion cubic feet in 1998).

The key issue for the natural gas infrastructure is the ability of the supply system to meet gas demand requirements on winter peak days. At times of peak gas demand, system operators rely on various methods to manage demand and obtain suitable supplies. Demand is managed by removing some users from the system, usually under the terms of interruptible service contracts. To ensure delivery to customers who generally pay higher rates for firm service, supplies from the pipeline system may be supplemented with inventories drawn from regional underground storage facilities or with smaller amounts of LNG or propane from storage. As demand rises to peak levels, maintaining gas service to firm customers requires the use of increasingly costly measures, eventually involving LNG and propane storage volumes. On average, net storage withdrawals provide 20 percent or more of total U.S. natural gas consumption during the winter period; however, reliance on storage can be much higher in some peak periods. For example, on a typical winter day, gas from storage meets 60 to 80 percent of Ohio's natural gas requirements. ${ }^{60}$

\section{Transportation}

Gas transportation pipelines entering the Northeast, including domestic lines from the Southwest into the Middle Atlantic region and cross-border lines from Canada, have a combined design capacity of 12.52 billion cubic feet per day, or an annual equivalent of 4.57 trillion cubic feet-well in excess of the region's total consumption of 2.9 trillion cubic feet in 1998. Existing pipeline capacity in many parts of the Northeast is adequate to meet current firm-service demand, and some of the area's pipeline systems have unused capacity on an annual basis. In fact, capacity utilization rates along pipeline corridors entering the Middle Atlantic and New England regions averaged 61 to 86 percent during $1998 .{ }^{61}$ During peak periods, however, most service providers are heavily, if not fully, utilized.

Transported gas is the major source of new gas supplies in the Northeast, and capacity entering the region grew by 13 percent from 1996 to the end of 1998. Expansion continued in 1999, with the completion of nine projects providing 1,080 million cubic feet per day, or about 0.4 trillion cubic feet per year, of additional capacity (Figure 35). More than half of the new capacity in 1999 (618 million cubic feet per day) was associated with the Maritimes and Northeast Pipeline and Portland Gas Transmission System projects, which will transport Canadian gas to the New England area. Those two projects alone increased overall pipeline capacity into the Northeast region by 5 percent. ${ }^{62}$

There are some problem areas in the Northeast. Pipeline capacity in the New York City area appears inadequate to meet growing market demand, as indicated by recent price spikes in the area due to several constraint points that have developed in recent years. The Leidy area of north central Pennsylvania (a major hub area with numerous interconnections among major interstate natural gas pipelines) is rapidly becoming a potential constraint for pipeline gas flowing to the East Coast, and particularly for northern New Jersey and New York City. Although the current pipeline capacity through the area appears sufficient, growing demand for gas trading and transport capacity probably will require some

\footnotetext{
${ }^{57}$ The last year of available EIA natural gas data with regional detail is 1998.

${ }^{58}$ Current supply is the sum of production, imports, and net inflow from other domestic regions. It excludes storage withdrawals.

59 "Supplies from the domestic transportation network" refers to the infrastructure from which the gas enters the region. The supplies may originate either as domestic production or as foreign production that passes through other U.S. regions.

60 Public Utility Commission of Ohio, Weather Impacts on Gas Cost and Residential Winter Heating Bills, 1996-1997 (January 31, 1997 ), p. 6.

61 Energy Information Administration, EIAGIS-NG (March 2000). 2000 .

${ }^{62}$ The completion of the Maritimes \& Northeast Pipeline occurred late in the year. It did not initiate flow to U.S. markets until January 4 ,
} 


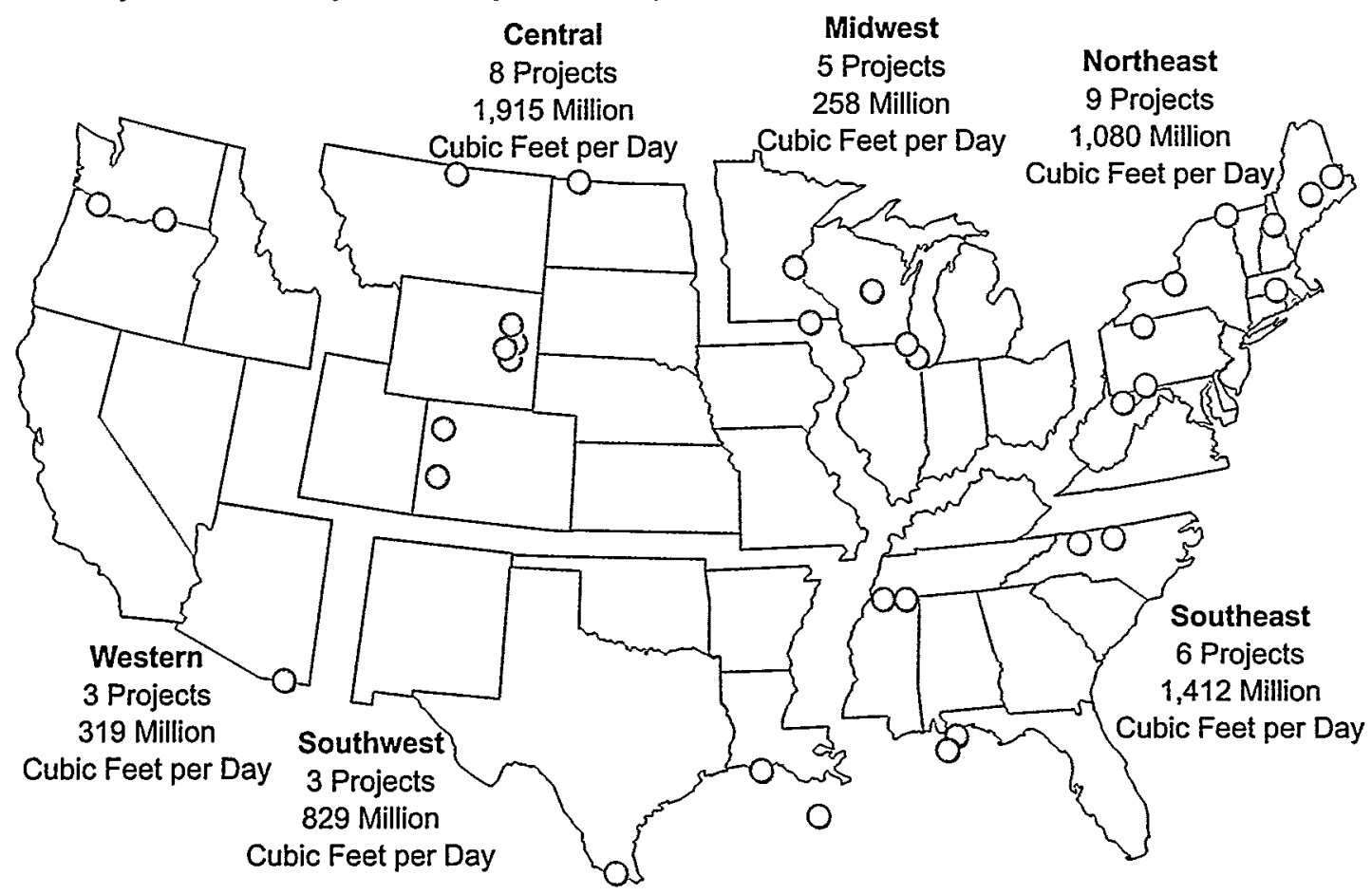

Note: A dot on the map indicates the location of either a compressor station expansion or the furthest delivery point along a segment of new pipeline capacity.

Source: Energy Information Administration, derived from EIAGIS-NG Geographic Information System, Natural Gas Pipeline Construction Database, as of March 2000.

expansion of existing pipelines. ${ }^{63}$ In the Boston metropolitan area, demand from developers of gas-fired power generation plants has been growing and is expected to grow more rapidly over the next decade, creating the potential for capacity shortfalls.

Another 23 interstate pipeline projects have been proposed for the Northeast region in 2000-2002-the largest number for any U.S. region (Figure 36). Several major projects were scheduled for completion by November 1 , 2000 , but delays in the approval process are expected to push back the startup dates for the Millennium, Independence, and several associated projects representing some 2 billion cubic feet per day of potential additional capacity. Given the competing nature of some proposals and the possibility of other alternatives to meet at least a portion of projected demand, generally not all proposed projects are expected to be built. ${ }^{64}$

The 23 projects proposed for the Northeast over the next several years would add a total of 5.9 billion cubic feet per day to the region's pipeline transportation capacity. The prospects are uncertain, however, for some of the projects. ${ }^{65}$ For example, the New York portion of the Millennium pipeline has been delayed due to regulatory concerns about its necessity and safety, and negative public reaction to parts of its proposed route, ${ }^{66}$ despite the fact that other sections have been approved by the Federal Energy Regulatory Commission (FERC) and the project is already underway. Some of the proposed projects involve new pipelines from the Midwest to the East Coast that would carry transshipments from

${ }^{63}$ Major pipeline segments operated by the Columbia Gas Transmission Company, CNG Transmission Company, National Fuel Gas Supply Corporation, Tennessee Gas Pipeline Company, Texas Eastern Transmission Company, and Transcontinental Gas Pipeline Company traverse the area around Leidy, Pennsylvania. The new Independence Pipeline and Transco Market-link projects both propose significant development of capacity in the area, and Tennessee Gas Pipeline and National Fuel Gas Supply Companies have also indicated tentative plans to expand segments of their systems in the area.

${ }^{64}$ Three projects that were originally announced for development in 2000 have yet to be filed with the FERC, and another 10 projects currently scheduled for 2000 in their filings have yet to be approved by the FERC.

${ }^{65}$ This simple summation of project capacities is for illustrative purposes. Because some of the projects are complementary and some are competing and might be mutually exclusive, the estimate of 5.9 billion cubic feet per day does not mean that these projects, if built, could satisfy additional market demand of that magnitude.

${ }^{66}$ For example, in January 2000, the New York Public Service Commission, fearing potential disruptions of electric service, asked FERC not to award final environmental clearance to the Millennium pipeline, because they were opposed to the sharing of a transmission right-of-way with Consolidated Edison Co. of New York as an "unacceptable risk." See "NY Pulls in Welcome Mat for the Millennium," NGI's Daily Gas Price Index (January 26, 2000). 
Figure 36. Proposed U.S. Gas Pipeline Expansions, 2000-2002

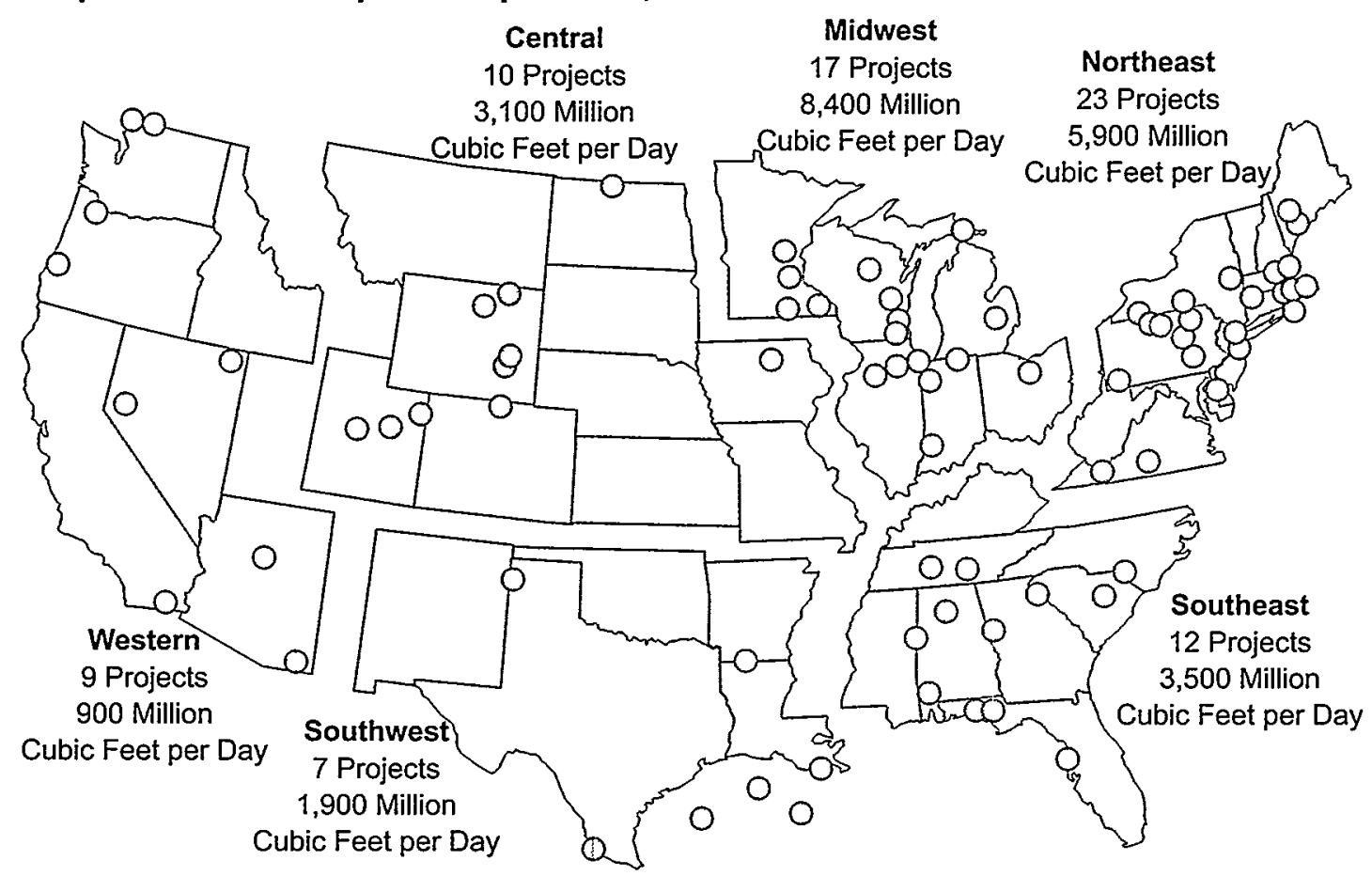

Note: A dot on the map indicates the location of either a compressor station expansion or the furthest delivery point along a segment of new pipeline capacity.

Source: Energy Information Administration, derived from EIAGIS-NG Geographic Information System, Natural Gas Pipeline Construction Database, as of March 2000; and Federal Energy Regulatory Commission, Applications for "Certificate of Public Convenience and Necessity."

cross-border pipeline projects bringing gas from Canada to the Midwest region. If one or more of the new domestic pipelines were not built, unused capacity on existing pipelines from the Midwest to the Northeast could pick up a portion of the excess import load; however, this would likely prove inadequate in the long term, and even if the new projects are brought to completion, the existing lines are likely to undergo expansion if Northeast demand continues to grow as expected.

\section{Storage and Local Distribution}

Two types of gas storage are currently in use in the Northeast: underground sites-primarily, depleted oil and gas reservoirs ${ }^{67}$ - and above-ground LNG facilities. LNG has a higher deliverability (or drawdown rate relative to stock levels) and is available in New England, but it is used only for short durations, generally to satisfy peak demand. Depleted oil and gas reservoirs take 5 months or more to fill and generally can be depleted over a 3-month period. The difference in flow performance for the two types of storage is reflected in their contributions to deliverability and capacity totals. Almost 95 percent of Northeast stock storage capacity in 1998 was attributed to underground facilities in western New York and Pennsylvania, which account for only 70 percent of maximum deliverability (Table 8 ). This difference affects supply availability: the LNG storage units contain only 8 days of supply when filled, as compared with more than 57 days of supply available on average from the underground units when they are filled. ${ }^{68}$

A simple view of gas storage is that it allows supplies to be acquired during periods of slow demand and delivered to end users during peak demand periods. In practice, however, storage utilization strategies tend to be more complex and interwoven with Public Service Commission requirements to provide reliable service to firm customers. Storage activities are managed to meet a combination of objectives: supplying gas to satisfy peak

${ }^{67}$ Salt cavern sites are becoming common in other regions of the country, but the only one in the Northeast as of December 1998 was the N.Y. State Electric \& Gas facility in Seneca county. Maximum deliverability from the site was only 80 million cubic feet per day, and it is included with the data for other underground units. Another potential underground storage option is lined rock cavern (LRC) storage, which is being researched currently. If commercially successful, LRC storage would be suitable for the Northeast. This option was not included in the present analysis.

${ }^{68}$ Days of supply is measured as the ratio of working gas capacity to peak day deliverability. LNG supplies and normal underground storage should not be combined for this calculation. The addition of LNG distorts the calculation because it has a very high deliverability for only short durations. In practice, flows diminish as underground stocks are depleted, and actual drainage of all working gas from depleted reservoirs would require more time. 
Table 8. Gas Storage Capacity and Deliverability in the Northeast, 1998

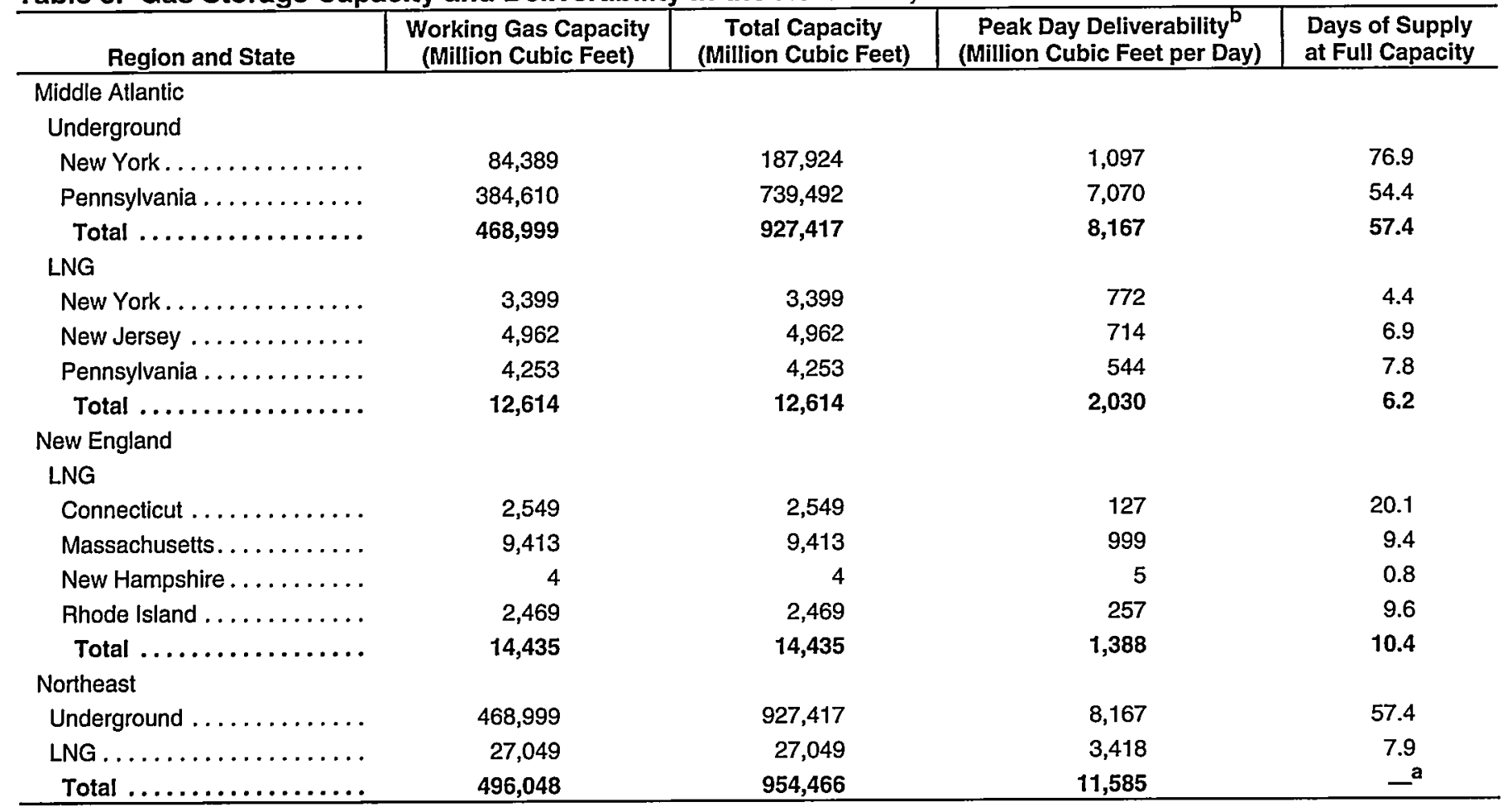

${ }^{\text {a }}$ LNG totals should not be added to underground storage, because LNG is normally used to satisfy peak demand when underground storage is also being used.

${ }^{b_{P}}$ Peak day deliverability at 11,585 million cubic feet per day is available only for about 8 days. For the remainder of the winter, without LNG, peak day deliverability is 8,167 million cubic feet per day.

Sources: Energy Information Administration (EIA), EIAGIS-NG Geographic Information System, Underground Natural Gas Storage Database and LNG Facilities Database, as of March 2000.

demand, balancing pipeline loads, and financial arbitrage. For the LDCs, which generally are responsible as the supplier of last resort, the ability to meet peak demand throughout the entire winter is arguably the predominant consideration, and their withdrawal strategies often reflect their concerns about being able to meet demand surges in the event of a late season cold snap. An unfortunate consequence of such a strategy is that reduced reliance on natural gas from storage restricts gas supplies to lower levels and may lead to higher prices in the short run. This apparently is what happened in the winter of 1996-1997, when gas was kept in storage during an early cold snap. Warm weather followed, and at least some withheld storage volumes were not needed later in the winter. ${ }^{69}$

Ideally, gas storage facilities in the Northeast would be sited close to major markets on the Atlantic coast, in order to minimize the time and expense required to move supplies to consumers and avoid potential transportation bottlenecks when demand surges. Proximity of storage facilities to end users would reduce the need for construction of additional pipeline transportation capacity to meet peak demands, allowing long-distance transportation lines to be designed to accommodate average flows, with some excess for responding to demand surges. Off-peak transportation would be able to move gas for baseload demand, storage replenishment, and incremental service to low-priority customers not supplied during peak periods. Local distribution networks in the Northeast already are designed to meet very high demand surges. ${ }^{70}$ For example, the 1999 flow capacity of transportation pipelines into New England is only 2.7 billion cubic feet per day, but local gas utilities managed peak deliveries of 3.4 billion cubic feet on January $17,2000.71$ The incremental sendout most likely represents a combination of storage gas and LNG imports.

There are distinct tradeoffs in performance and cost among storage, transportation pipelines, and LDCs. Although there are advantages to storage in managing transportation costs, reliance on storage incurs costs for injection (into an underground reservoir or conversion to LNG for above-ground storage), storage, and

\footnotetext{
${ }^{69}$ Energy Information Administration, "Natural Gas Residential Pricing Developments During the 1996-97 Winter," Natural Gas Monthly, DOE/EIA-0130(97/08) (Washington, DC, August 1997).

${ }^{70}$ In some areas, gas is delivered directly to consumers by interstate pipeline companies, bypassing the LDCs. This practice is not thought to be widespread in the Northeast.

71 “New England's Natural Gas Industry Reaches New Growth Levels," New England Gas Association Press Release (March 23, 2000), web site biz.yahoo.com/prnews/000323/ne_gas_ass_1.html.
} 
withdrawal (or LNG regasification) that add directly to the unit costs of delivered gas. Further, in responding to the needs of a growing market, the costs of incremental storage expansion are likely to be higher than the average to date. The number of potential future underground storage sites is limited, and siting of new LNG storage tanks tends to be problematic, encountering local resistance that can increase costs even when it is successfully overcome. Generally, the high deliverability and higher costs make LNG storage most suitable as a source of supply in periods of extreme peak demand.

\section{Sales and Service Contracts}

Because natural gas demand is seasonal and pipeline systems generally are designed to handle expected loads during periods of peak demand (for example, pipelines typically are operated at as much as 120 percent of design pressures ${ }^{72}$ to increase "line pack" during shortterm demand peaks), spare capacity usually is available during off-peak periods, even after accounting for gas to replenish storage inventories. The combination of fixed pipeline capacity and variable load has led to the development of interruptible service contracts for some natural gas customers, as opposed to firm service contracts, which guarantee uninterrupted gas supplies throughout the year. Interruptible service contracts with pipeline operators or LDCs vary in terms and conditions but, generally, allow for service interruptions as a result of either temperature threshold triggers or system operating conditions (for example, when line pressure is threatened by high rates of drawdown on the system). In addition, some contracts provide firm service only for a limited duration, such as a month, or on a seasonal basis, with suspensions of service permitted during the winter. Suspension of service is not considered an interruption as long as the terms of the arrangement are fully met. Roughly 10 to 15 percent of all natural gas deliveries to U.S. consumers by interstate pipelines in 1997 were on an interruptible basis, down substantially from roughly half of all deliveries in the late $1980 \mathrm{~s}^{73}$

Interruptible gas contracts and firm service on a temporary basis allow pipeline operators to increase utilization of their fixed assets and better manage costs of service on average. Higher utilization overall enhances the economic return on pipeline assets, encourages further investments in the gas delivery system, and provides opportunities for large-volume energy consumers, such as industrial customers and electricity generators, to obtain energy supplies at lower prices. Sales of off-peak interruptible capacity also generate revenues that contribute toward at least a portion of pipeline capital costs, providing benefits to firm service customers as well.

Natural gas service may also be suspended voluntarily by some customers with switchable or dual-fuel capability, even when delivery capacity is available. For example, there are reports that some demand shifted from natural gas to distillate fuel oil during January and February 2000 because of the relative fuel prices, although most information to date on this market behavior is only anecdotal. Understanding this behavior and the motives behind it, based on relative fuel prices, is important.

Preliminary information indicates that there were interruptions of gas service in the Northeast in January 2000 as a result of both temperature and operating conditions. ${ }^{74}$ There were no interruptions under firm service contracts, and there were no service interruptions at all in February. During January 2000, operational flow orders (OFOs) were issued by three pipeline companies serving the Northeast, alerting customers that they were expected to manage their gas takes from the system to conform strictly to the terms of their contracts. This was done by the pipelines for purposes of load management, and it does not indicate a reduction in service below capacity levels.

Interstate transporters and LDCs go to great lengths to avoid performance failure under firm service contracts because of the serious implications for their customers and others. (Although quite rare, interruptions may occur under firm service contracts when extreme conditions diminish system capability to the point that deliveries cannot be made to meet all of the supplier's firm contract obligations.) The companies also try to continue service even under interruptible contracts, subject to the availability of capacity during peak periods and the ability to continue service without resort to high-cost measures, such as propane injection, that are not provided for under interruptible service fees. As a result, interruptions are a regular feature of the gas industry. The movement to regulatory reform at the Federal and State levels has not altered the basic role or impact of interruptible gas contracts. The distinguishing characteristic of regulatory reform in the natural gas industry is a separation of commodity sales from other services. The impact of

\footnotetext{
${ }^{72}$ A pipeline's design capacity is defined as the maximum throughput that can be sustained throughout the year. Actual flow can exceed the design capacity for brief periods.

${ }^{73}$ Interstate Natural Gas Association of America, Gas Transportation Through 1997, Report No. 99-01 (April 1999). The stated percentages reflect primary capacity contract arrangements. Through capacity release transactions, at least some of the capacity held by firm contracts is resold on an interruptible basis.

${ }^{74}$ ELA is conducting a data collection effort directed to local distribution companies in an attempt to develop independent, statistically based estimates of gas service interruptions and their impact on distillate fuel oil markets across the Northeast. Results will be provided in a study scheduled for release later in 2000.
} 
and response to a failure to deliver gas are the same whether the contract is for service only or for service and sales of gas to the customer.

\section{Prices}

End-use prices for natural gas are determined by the costs of the commodity (fuel) and related supply services (transportation, storage, and local distribution). They also reflect the type of service provided (firm or interruptible). For residential users, gas commodity price is only about 30 percent of the delivered price, and the remainder reflects the cost of services between the wellhead and the burnertip on a firm service basis. Because natural gas commodity prices are a small percentage of the delivered price, fluctuations in the gas commodity price result in much smaller relative changes in the delivered price to small-volume customers.

Small-volume customers, such as residential and some commercial and industrial consumers, generally receive their gas from LDCs, which typically bill their customers monthly. Monthly billing smooths out some of the daily price volatility seen in upstream markets, but it also introduces an information lag. Bills arrive after the billing period during which consumption decisions have been made, and the bill is stated in terms of totals or averages for the period. It is difficult at best for consumers to ascertain their marginal costs for timely decisions within the consumption period. Thus, if upstream supply prices rise rapidly, small-volume customers are not likely to be aware of the change in prevailing prices until after the billing period.

Effective price signals to residential customers also are limited by residential billing procedures, such as levelized billings, that are designed to avoid unexpected large increases in monthly gas expenditures when possible. This objective has resulted in the availability of consumer options such as budget-payment plans, in which the consumer is charged a uniform rate for 11 months, and discrepancies between cumulative payments and costs are addressed in the 12th month. ${ }^{75}$ Budget-payment plans obscure not only the marginal cost of additional gas units consumed on any day, but also the average cost for the month or season. ${ }^{76}$

Natural gas billing methodologies can help the consumer by blunting the immediate impact of gas price fluctuations, but they do not provide a means to avoid paying their gas costs. In fact, residential prices and bills can rise dramatically during the heating season. A prime example occurred during the winter of 1996-1997. Nationally, although gas consumption was down 5.7 percent from the prior year, monthly prices were 10 to 20 percent higher, resulting in an expenditure increase by residential customers of 9 percent for the entire heating season.

Large-volume customers vary in their approach to gas acquisition, because the scale of their energy use provides opportunities that generally are unavailable to small-volume customers. Large customers tend to purchase gas "off system" directly from a marketer or producer and contract for delivery separately, rather than purchasing from a merchant LDC. The companies seek the best deals for their requirements, and if energy is particularly important to their operations they may even utilize an energy acquisition unit that specializes in sophisticated market trading.

Large-volume customers that cannot switch from natural gas depend on gas-on-gas competition and competition between service providers for advantages in their deals. Those with dual-fuel or switchable capability look for the least expensive fuel, relying on interfuel competition to yield advantageous transactions. The alternate fuel used by consumers who have natural gas as one option generally is distillate or residual fuel oil. The gas commodity itself, excluding the addition of substantial transportation, delivery, and storage charges, typically is much less expensive than petroleum products on a Btu basis. When natural gas delivery can be arranged at discounted rates, the combined costs result in an economic advantage generally favoring gas use; however, discounted service usually is available only under interruptible contracts.

\section{Evaluating the Effects of Changes in Natural Gas Consumption Patterns}

The potential for large-volume consumers of distillate to switch to natural gas varies over the short term versus the longer term horizon. The goal under the short-term scenario would be to prevent large-volume dual-fuel customers, including those with interruptible gas service contracts, from entering the distillate market to purchase distillate fuel oil during peak demand periods. In the longer term scenario, an additional goal would be to shift at least some large-volume consumers of distillate fuel oil (not currently able to switch) to year-round

\footnotetext{
${ }^{75}$ Complete reconciliation may not be achieved in a single month, depending on the amount owed by the consumer. The objective of these plans is to "smooth" the amounts owed by the customer, and in practice, ad hoc adjustments are introduced to achieve that goal. For example, payments under a budget-payment plan may be adjusted upward, even when out of cycle, if costs have risen so much that further delays in cost recovery are likely to result in a substantial "shock" if allowed to accumulate until the next reconciliation month. Thus, even customers under a plan for payment smoothing will experience some impact from a sudden, large increase in upstream gas prices.

${ }^{76}$ Alternative payment plans are not particular to natural gas markets. Similar plans are offered to heating oil customers.
} 
use of natural gas. ${ }^{77}$ In both cases, demand for natural gas in the Northeast region would be expected to rise above the levels already expected to result from the continuation of current market trends. The focus of this analysis is to estimate the effect of such shifts on natural gas infrastructure requirements.

One measure that provides insight into the potential short-term impact is provided by estimating the incremental load that shifted from natural gas to distillate fuel oil in the Northeast in January 2000. A comprehensive, direct estimate of the energy volumes affected is not available. In Chapter 3 of this report, it is estimated that the maximum switchable dual-fuel capability in the Northeast during a colder-than-normal winter heating season (December-February) is 133,000 barrels per day. That analysis is extended here to estimate the implications of such a switch on the natural gas infrastructure. A separate estimate of incremental demand for distillate fuel oil due to gas service interruptions in the short-term scenario was developed by EIA from in-house data and information provided by State agencies in New York, New Jersey, Connecticut, and Massachusetts-four of the top distillate-consuming States in the Northeast. The increase in distillate consumption from customers shifting out of natural gas is estimated at roughly 97,000 barrels per day. ${ }^{78}$ The impact of distillate purchases by such customers, however, remains unclear pending results of an EIA survey of customers whose gas service was interrupted. This volume is equivalent to incremental peak demand of 510 million cubic feet of natural gas per day in the Middle Atlantic region and 40 million cubic feet per day in New England. ${ }^{79}$ The long-term impact, through 2005, includes the projected market growth in the Northeast in the reference case of the Annual Energy Outlook 2000 (AEO2000), the short-term impact, and the additional effects of shifting large-volume consumers of distillate fuel oil to natural gas through equipment conversions and retrofits.

A number of uncertainties are involved in estimating natural gas infrastructure requirements. EIA's $A E O 2000$ forecast, available monthly data, anecdotal evidence, and a number of assumptions were used in developing the estimates presented here. The initial focus of the analysis was to estimate the average daily natural gas and distillate consumption levels for a more extreme peak month. ${ }^{80}$ In reality, peak day consumption levels can exceed average peak month levels by consequential amounts. However, for the purposes of this analysis it was assumed that natural gas storage and pipeline infrastructure requirements would increase in proportion to the increase in the estimates for the average daily consumption within the peak month. Estimates of 1999 and 2005 business-as-usual energy requirements for the Northeast were based on annual consumption projections from the $A E O 2000$ reference case, which shows distillate consumption in 2005 that is 11 percent higher than 1999 consumption in the industrial sector, 10 percent lower in the residential sector, and 39 percent lower in the electricity generation sector.

Peak-month volumes for natural gas in a colder-thannormal winter (Table 9) were estimated on the basis of the peak month to average annual ratios that occurred in 1994, a recent cold winter, and applied to the 1999 and 2005 reference case forecast from AEO2000. The methodology used in Chapter 3 (see Table 7) to derive estimates of switchable distillate consumption by large-volume, dual-fired customers in the winter season (December to February) was applied to 1999 base levels. The estimates were then converted to peak-month values by assuming that 40 percent of the winter consumption occurs in the peak month. The resulting values represent an estimate of the amount of distillate consumption in a colderthan-normal peak month that could be switched to natural gas in the short term without conversions or retrofits of existing equipment. These values include natural gas consumption that would have been switched to distillate fuel due to gas service interruptions.

Over the longer term, by 2005, it was assumed that some of the large-volume distillate users not currently dual-fired could convert to natural gas use with equipment conversions or retrofits. For the sake of this analysis, the extreme position was taken that all such users

\footnotetext{
77 Present small-volume heating oil customers, such as residential and commercial consumers, can shift to natural gas also, but the present analysis is limited to large-volume customers. In general, small-volume consumers do not have strong economic incentives to switch from distillate.

${ }^{78}$ The EIA estimate is based on confidential data and therefore cannot be described in detail; however it is quite close to the 100,000 barrels per day estimated independently by the Petroleum Industry Research Foundation (cited in Chapter 2).

${ }^{79}$ Although not essential to the present analysis, the market impact of energy consumers shifting from natural gas to distillate depends on market transactions, and not on changes in fuel oil consumption, which are not necessarily equivalent. They can differ due to consumer use of on-site stocks of their alternative fuel, thus resulting in market purchases less than the daily consumption increase. On the other hand, the purchasing practices of switchable customers might increase transactions by more than the increase in consumption: i.e., on the day of purchase, large-volume users may buy fuel oil supplies for a number of days or longer. An analysis of the fuel oil market response also would depend on the duration of the incremental demand, because the cumulative drawdown would affect available inventories. Because the present analysis is concerned with the magnitude of incremental switching volumes to estimate gas capacity requirements at peak, duration is not considered to be relevant.

${ }^{80}$ Although the schedule of distillate purchases can have a significant impact on the distillate market, this analysis estimates distillate consumption, as opposed to purchases, because the focus is to calculate the comparable level of natural gas that would be consumed if natural gas were consumed in place of distillate.
} 
Table 9. Average Daily Consumption of Natural Gas in the Peak Month Before and After Switching from Distillate to Natural Gas in the Northeast

\begin{tabular}{|c|c|c|c|c|}
\hline \multirow[b]{2}{*}{ Region } & \multicolumn{2}{|c|}{ Short Term } & \multicolumn{2}{|c|}{ Longer Term (2005) } \\
\hline & $\begin{array}{c}\text { Million } \\
\text { Cubic Feet }\end{array}$ & $\begin{array}{l}\text { Million } \\
\text { Barrels }^{\mathrm{a}} \\
\end{array}$ & $\begin{array}{c}\text { Million } \\
\text { Cubic Feet }\end{array}$ & $\begin{array}{l}\text { Million } \\
\text { Barrels }^{a}\end{array}$ \\
\hline \multicolumn{5}{|l|}{ New England } \\
\hline 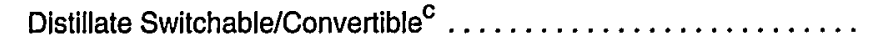 & 298 & 53 & 566 & 100 \\
\hline Total Consumption After Switching $\ldots \ldots \ldots \ldots \ldots \ldots$ & 2,703 & 477 & 3,148 & 556 \\
\hline \multicolumn{5}{|l|}{ Middle Atlantic } \\
\hline Base Natural Gas Consumption (Not Switchable). . . . . . . . & $10,572^{b}$ & 1,868 & 11,182 & 1,975 \\
\hline Distillate Switchable/Convertible $^{c} \ldots \ldots \ldots \ldots \ldots \ldots$ & 566 & 100 & 976 & 172 \\
\hline Total Consumption After Switching $\ldots \ldots \ldots \ldots \ldots \ldots$ & 11,138 & 1,968 & 12,158 & 2,148 \\
\hline $\begin{array}{l}\text { Percentage Increase From Short-Term Base Consumption } \\
(10,572 \text { Million Cubic Feet per Day }) \ldots \ldots \ldots \ldots \ldots \ldots \ldots \ldots \ldots \ldots\end{array}$ & $5.4 \%$ & $5.4 \%$ & $15.0 \%$ & $15.0 \%$ \\
\hline \multicolumn{5}{|l|}{ Northeast } \\
\hline Total Consumption After Switching $\ldots \ldots \ldots \ldots \ldots$ & 13,841 & 2,445 & 15,306 & 2,704 \\
\hline $\begin{array}{l}\text { Percentage Increase From Short-Term Base Consumption } \\
(12,977 \text { Million Cubic Feet per Dayb }) . \ldots \ldots \ldots \ldots \ldots \ldots \ldots \ldots \ldots\end{array}$ & $6.7 \%$ & $6.7 \%$ & $17.9 \%$ & $17.9 \%$ \\
\hline 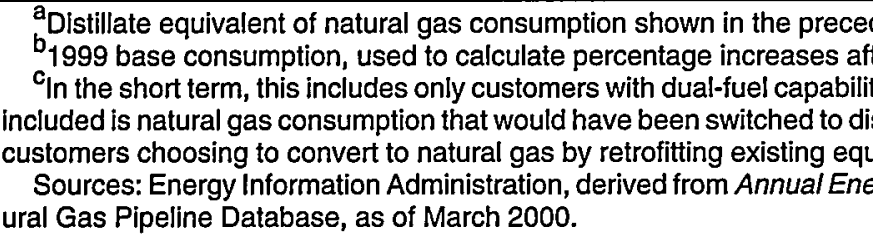 & te due to gas & ew equip & $\begin{array}{l}\text { longer term. } \\
\text {, using existin } \\
\text { the longer te } \\
\text { burn natural } \\
\text { graphic Inform }\end{array}$ & $\begin{array}{l}\text { ipment. Also } \\
\text { also includes } \\
\text { System, Nat- }\end{array}$ \\
\hline
\end{tabular}

would convert to natural gas by 2005 . As in Chapter 3 , the customers in this category, in combination with the dual-fired customers, were assumed to include all the distillate consumption in the electricity generation sector, the space heating portion of the commercial sector (52 percent), and the manufacturing segment of the industrial sector ( 48 percent). These factors were applied to the 2005 distillate consumption levels from the $A E O 2000$ reference case. The reference case shows the following increases in natural gas consumption in the Northeast from 1999 to 2005 by sector: residential, 2.9 percent; commercial, 3.5 percent; industrial, 10.6 percent; and electricity generation, 152 percent. For the commercial and electricity generation sectors, the process used to convert annual estimates of switchable distillate consumption to a peak month was the same as used for the short-term analysis. For the industrial sector, it was assumed that 20 percent of the switchable distillate consumption in a year would occur in the peak month.

Using the ratio of estimated peak-day consumption to average day consumption, peak day natural gas requirements in the Northeast in the near term could increase by 864 million cubic feet per day over the 1999 estimated peak consumption levels (Table 9). In the longer term, a scenario in which all large-volume distillate consumers in the Northeast shifted to natural gas would increase peak-month consumption of natural gas by up to 2,329 million cubic feet per day from the 1999 base by 2005 . This scenario could raise peak-month natural gas consumption by 15 percent in the Middle Atlantic region and by 31 percent in New England by 2005 above the short-term base. The associated capacity expansion requirements could be substantial.

\section{Pipeline Capacity Requirements}

Because the Northeast relies heavily on natural gas supplies from outside the region, the interstate transportation system is a key element in satisfying demand increases. Given the general lack of interruptible service on the system during late January 2000, additional loads at peak times would require expanded capacity. Estimated new pipeline capacity entering a region must reflect the needed increase to accommodate the load that otherwise would have shifted to or remained with distillate fuel oil, and to handle the increase in the peak day volumes resulting from the shift to gas.

Estimated natural gas pipeline capacity entering New England at the beginuing of 1999 was 2,739 million cubic feet per day. It is estimated that an additional 340 million cubic feet per day of capacity into New England would be required to support the short-term shift to gas. By 2005, the initial 1999 capacity would need to be increased by 846 million cubic feet per day. The recently built Maritimes and Portland pipelines (618 million 
cubic feet per day) should be sufficient for the indicated requirements in the short term, and they probably can meet a portion of the additional longer term requirements. ${ }^{81}$ Pipeline capacity entering the entire Northeast region was 12,519 million cubic feet per day at the beginning of 1999. The shift from distillate to gas could require additional pipeline capacity of 839 million cubic feet per day in the short term and 2,241 million cubic feet per day by 2005 (Table 10). ${ }^{82}$ The higher estimates represent a more successful conversion scenario, and the lower estimates reflect a more conservative assumption about the willingness and ability of large-volume consumers to shift from distillate fuel oil.

The arrival of gas into the Middle Atlantic and New England regions is the first stage of the supply process. Subsequent delivery of the gas to consumers would require the intraregional infrastructure to handle local distribution and management of system loads to meet the new peak load requirements. The introduction of the estimated new firm demand would require either new construction or the identification of uncommitted local capacity and assignment of that capacity to the new customers. The likelihood of identifying spare capacity that is properly positioned to serve the entire incremental load is low.

The need for new or additional pipeline capacity to meet the growing demand for natural gas in the Northeast can be handled in several ways, each with particular physi$\mathrm{cal}$ and/or financial advantages and disadvantages. The least expensive option, often the quickest and easiest, and usually the one with the lowest environmental impact is to upgrade facilities on existing routes. Typically, new pipelines, for which right-of-way land must be purchased, new pipeline laid, and operating facilities installed, would cost much more than expansion of existing routes. For instance, a new pipeline, such as the proposed long-distance Alliance Pipeline system, is expected to cost as much as $\$ 1.81$ per added cubic foot of daily capacity. In contrast, the relatively shortdistance Texas Eastern Lebanon expansion project is expected to cost about $\$ 0.25$ per added cubic foot of daily capacity. When recently completed and proposed projects are categorized by project type, new pipeline projects average about $\$ 0.48$ per added cubic foot, major expansions about $\$ 0.33$ per cubic foot, and small (compression-only) expansions about $\$ 0.15$ per cubic foot of capacity (Figure 37). ${ }^{83}$

\section{Figure 37. Average Costs for New Pipeline} Capacity in the Northeast, 1996-2000

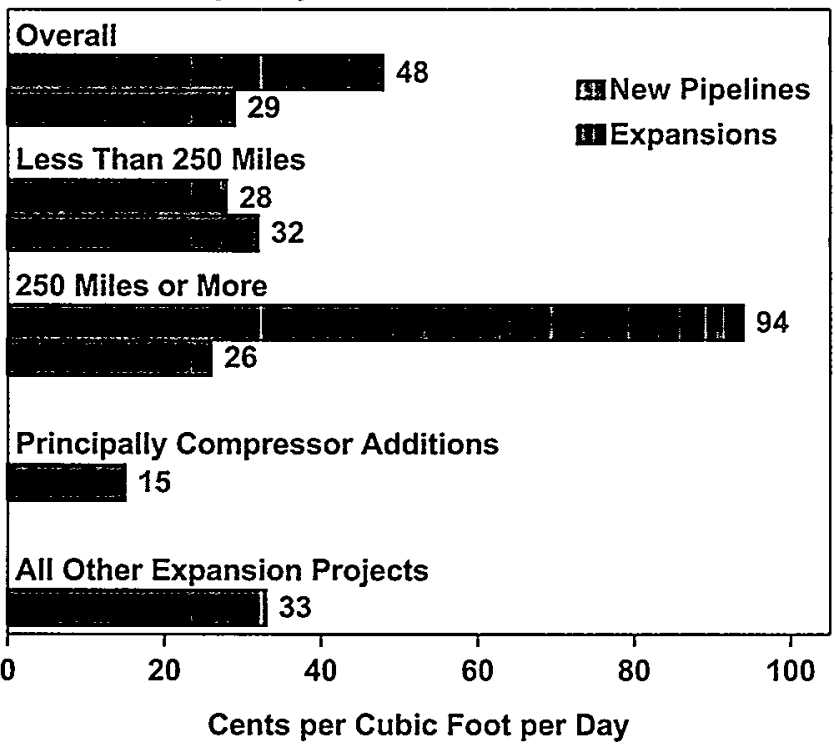

Note: Data for each category were not available on all projects. For example, estimated or actual project costs or miles of pipeline were not announced or not available until filed with the Federal Energy Regulatory Commission. In some cases, where profiles of projects were similar but for which one cost was unavailable, an estimated cost was derived and assigned to the project based on known data.

Source: Energy Information Administration (EIA), EIAGISNG Geographic Information System, Natural Gas Pipeline Construction Database, as of August 1998.

\section{Table 10. Projected Pipeline Capacity Requirements Entering the Northeast Region If Large-Volume Distillate Consumers Switch to Natural Gas} (Million Cubic Feet per Day)

\begin{tabular}{|c|c|c|c|}
\hline Region & 1999 Base Level & Short Term & Longer Term \\
\hline New England $\ldots \ldots \ldots \ldots \ldots \ldots$ & 2,739 & 3,079 & 3,585 \\
\hline Middle Allantic . ............... & 11,889 & 12,531 & 13,672 \\
\hline Northeast $\ldots \ldots \ldots \ldots \ldots \ldots \ldots \ldots$ & 12,519 & 13,358 & 14,760 \\
\hline
\end{tabular}

Source: Energy Information Administration, EIA GIS-NG Geographic Information System, Natural Gas Pipeline Database, as of March $2000 .$.

\footnotetext{
${ }^{81}$ Although new pipeline generally is built to service an expanding market, it can also serve to relieve low pressure areas on the existing system and to offer competitively priced gas from an alternative source to an area already served, thus displacing existing capacity. Furthermore, pipelines are built to target specific customers in a region. The resulting pipeline may not be suitably located to serve an unanticipated emerging market, such as consumers wishing to switch from distillate to natural gas use.

${ }^{82}$ Peak day consumption is met also by storage withdrawals, and so flow capacity into the region increases by less than the rise in peak day consumption.

${ }^{83}$ Pipeline construction cost estimates are from Energy Information Administration, Natural Gas 1998: Issues and Trends, DOE/EIA0560(98) (Washington, DC, June 1999).
} 
The cost of a project also varies according to location. Projects that must go through major population areas, as in the Northeast region, on average cost more than those developed in more sparsely populated areas. Although many of the projects completed in the Northeast in recent years have been expansions of existing systems, which are less expensive overall, future development in the region will include large new and expansion projects that are, on average, more expensive. For instance, 13 projects were completed in the Northeast Region during 1996 and 1997 at an average cost of about $\$ 0.22$ per cubic foot of added daily capacity, 84 but projects over the next 3 years are expected to average about $\$ 0.37$ per cubic foot. Based on the rough averages of $\$ 0.37$ per cubic foot of expansions and new construction in the Northeast and $\$ 0.48$ for new pipelines nationwide, the estimated capital costs for incremental interregional capacity would range between $\$ 829$ and $\$ 1,076$ million for the full impact of policies that eliminate switching from and promote conversion to natural gas. These estimates are for pipelines from the border through the Northeast region. They do not include additional capacity that might be required to transport gas to the Northeast border.

On average, construction and expansion projects completed in 1996 or 1997 took about 3 years from the time they were first announced until they were placed in service. Construction itself typically was completed within 18 months following FERC approval, sometimes in as little as 6 months. The remainder of the period was consumed with the initial open season ( 2 months), plan development prior to filing ( 3 months), and FERC review and reaction to FERC revisions, if any. Generally, FERC review takes from 5 to 18 months, averaging about 15 months. ${ }^{85}$ When approval is delayed, however, the schedule can be extended considerably. For example, two of the four major pipeline proposals for capacity expansion into the Northeast, the Independence and Millennium projects, have been seeking FERC approval for more than a year, and their possible in-service dates now appear to be no earlier than 2001 (Table 11). The combined cost of the two projects and associated projects exceeds $\$ 1$ billion. These two projects would provide a combined 1,700 million cubic feet per day of new pipeline capacity, which would appear sufficient to serve most of the projected incremental demand. ${ }^{86}$

\section{Natural Gas Storage Requirements}

The short-term shift to retain all gas consumers on the system year-round would heighten the peak day gas demand. Severe "needle peaks" would require timely supply responses, likely depending on volumes from storage. Although deliverability from storage, including LNG, is 10,197 million cubic feet per day in the Middle Atlantic, and 1,388 million cubic feet per day in New England, use of this gas as a frequent source of supply during peak periods would also depend on the aggregate storage capacity. Storage in underground sites contains less than 2 months of supply at maximum working gas capacity. Storage drawdowns from LNG facilities at close to maximum rates would exhaust LNG supplies in less than a week in the Middle Atlantic region and in 10 days in New England (Figure 38).

Given the more severe peaks in demand for natural gas that can be anticipated with an aggressive shift to natural gas, storage capacity and deliverability likely would have to be increased by more than the proportionate rise in regional demand. However, using the demand increase as a conservative guideline for the needed regional storage capacity and deliverability, they would need to be expanded by up to 15 percent in the Middle Atlantic region and 31 percent in New England, requiring an increase of 70 billion cubic feet in underground

Table 11. Proposed Pipeline and Capacity Expansion Projects into the Middle Atlantic Region

\begin{tabular}{|c|c|c|c|c|c|}
\hline Name & $\begin{array}{c}\text { From } \\
\text { Region }\end{array}$ & States Involved & $\begin{array}{l}\text { Possible First } \\
\text { Year of Service }\end{array}$ & Status & $\begin{array}{c}\text { Incremental Capacity } \\
\text { (Million Cubic Feet } \\
\text { per Day) }\end{array}$ \\
\hline Independence Pipeline . & Midwest & IL, IN, OH, PA, NY & 2001 & Pending FERC Approval & 1,000 \\
\hline $\begin{array}{l}\text { Iroquois Gas Pipeline } \\
\text { Eastchester Expansion . . . . . . . }\end{array}$ & Canada & NY & 2002 & Not yet filed & 220 \\
\hline
\end{tabular}

Note: No firm proposals to expand pipeline capacity into the New England region have been announced or filed with the FERC during the past year. The Portland Natural Gas Transmission Company held an open season for possible expansion of its recently (1998) completed 178 million cubic feet per day import system but has yet to announce the results of the market test. The Maritimes and Northeast Pipeline (400 million cubic feet per day), completed in late 1999, can be expected to expand as Sable Island (Canada offshore) gas production continues to be expanded, but no plans to do so have been officially announced.

Source: Energy Information Administration, derived from EIAGIS-NG Geographic Information System, Natural Gas Proposed Pipeline Construction Database, as of March 2000; and Federal Energy Regulatory Commission, Applications for Certificate of Public Convenience and Necessity.

\footnotetext{
${ }^{84}$ One of the reasons for this was that almost all of the projects were low-mileage or compression additions rather than long-haul new pipelines.

${ }^{85}$ Federal Energy Regulatory Commission, Office of Pipeline Regulation, Case Tracking System.

${ }^{86} \mathrm{~A}$ complete determination of the ability of these specific projects to satisfy the projected demand would require a detailed analysis that is beyond the scope of the present effort.
} 
Figure 38. Regional Daily Deliverability from Underground and Liquefied Natural Gas Storage in the Northeast, 1998

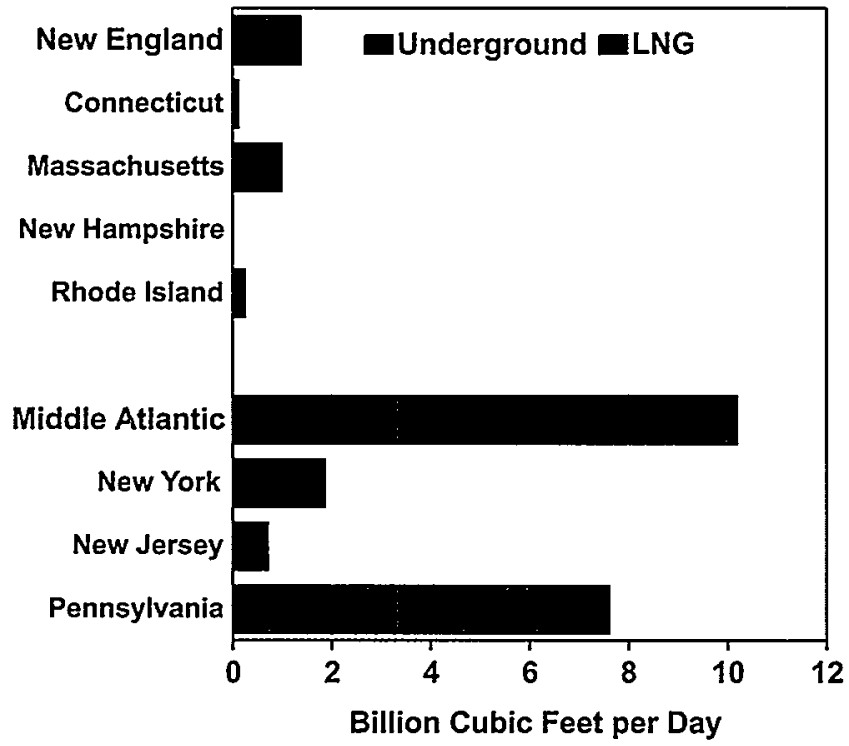

Source: Energy Information Administration, EIAGIS-NG Geographic Information System, Underground Natural Gas Storage Database and LNG Facilities Database, as of March 2000.

working gas capacity and 1,225 million cubic feet per day in deliverability in the Middle Atlantic region and an increase of 6.4 billion cubic feet in LNG working gas capacity and 733 million cubic feet per day in deliverability in the Northeast. The siting of new storage units could present a formidable challenge in light of previous experience. For example, 12 underground storage projects were proposed in New York and Pennsylvania for the 4-year period 1995-1998, with an associated working gas capacity of 40.2 billion cubic feet. The projects included 8 salt dome or salt bed projects with 14 billion cubic feet of working capacity. ${ }^{87}$ By the end of 1998 , only the smallest of the salt projects had been built. Based on the estimated average cost of $\$ 8.7$ million per billion cubic feet for the 12 projects, achieving 70 billion cubic feet of additional underground capacity alone would require an estimated $\$ 609$ million.

A final option relies on propane supplies as a source of peak shaving supplies. Propane can be stored on site and then used to meet peak load requirements, but in practice its use is limited for several reasons. First, storage facilities for petroleum products are not well received in many locations for environmental reasons. Second, propane is an expensive source of supply. Third, increased reliance on propane, even if economically viable, would not disentangle the natural gas and petroleum fuels markets. Its regular use in supplementing gas supplies would require operators to purchase propane supplies to replenish depleted stocks. Given that average propane sales for any month in the New England and Central Atlantic regions ${ }^{88}$ only occasionally exceed 100,000 barrels per day, the redirection of just a fraction of switchable energy demand to propane probably would overwhelm the regional propane market, potentially causing severe price spikes.

\section{Economic and Institutional Obstacles to Gas Conversion}

Although the natural gas industry in the Northeast probably could accommodate the infrastructure requirements of a shift from distillate to gas by large-volume consumers, economic and institutional obstacles may be more problematic. The economics indicate that the shift would be likely to involve about $\$ 1.5$ billion in capital costs for pipeline capacity into the region, additional storage facilities, and additional investment in local distribution capacity. In addition, regulatory, environmental, and public perception issues would have to be addressed (see box on page 49). Local resistance to projects can be fierce, despite the vested interest of communities in increased access to gas supplies. This is especially problematic in terms of moving gas into and through States to provide benefits on a regional basis. For example, Transco has proposed an expansion project that will traverse New Jersey.

The conflicting goals of cost recovery and attracting new customers through low service charges present an especially difficult problem that will affect pricing strategies. Capital expansion and the associated expenditures needed to retain large-volume customers that otherwise would be subject to interruption of gas service are unlikely to enhance service to other firm service customers. The direct association between the incremental investment and costs with an identifiable group of customers is likely to discourage acceptance of rolled-in (average) pricing by State Utility Commissions, and the likelihood for success of incremental pricing is unclear. Current large-volume customers were enticed to gas by offers of heavily discounted rates. Higher prices may not discourage gas use if the discounted rates were due to gas-on-gas rather than interfuel competition, but the nature of the competition cannot be determined beforehand. If delivered prices under the proposed policies are higher than the delivered prices with interruptible service under the current system, the additional costs may actually discourage gas use. Unless the conversion to

\footnotetext{
${ }^{87}$ Energy Information Administration, The Value of Underground Storage in Today's Natural Gas Industry, DOE/EIA-0591 (Washington, DC, March 1995).

${ }^{88}$ The Central Atlantic region includes Delaware, District of Columbia, Maryland, plus the Mid-Atlantic Census Division, which is composed of New Jersey, New York, and Pennsylvania.
} 


\section{Environmental Considerations for Natural Gas Pipeline Expansion Projects}

The environmental impacts of natural gas pipeline construction for interstate transportation or local distribution projects depend on project size, length, and design. A large greenfield pipeline route, built from scratch, necessitates a good deal of environmentally sensitive action compared with a project that only involves the upgrading of existing facilities to expand capacity. For instance, planning of a new route must include an evaluation of its need to cross wetlands, wildlife-sensitive areas, and potential archaeological sites. Alternative routes must also be available in the event that regulatory authorities withhold approval. Other impacts that must be evaluated include the effects of clearing construction routes and building access roads, the temporary or permanent redirection of waterways, possible discharges of oil-residues (when converting an oil line), and discharges of hydrostatic test water when leaks are detected.

The potential environmental impacts of completed projects must also be considered, such as emissions and noise from compressor station operations. When natural gas is used to fuel a compressor station, the unit will emit approximately 50 tons of nitrogen oxide, 75 tons of carbon monoxide, and 50 tons of volatile organic compounds per year (based on continuous year-round operation of a unit with a 3,300 horsepower rating). Some compressor stations use electricity rather than natural gas for fuel; their on-site direct emission levels are zero, although off-site emissions result from electricity generation.

The National Environmental Policy Act of 1969 (NEPA) requires that anyone proposing to undertake a major interstate-related project, such as construction of a pipeline, LNG import terminal, gas storage field, or other major project that may have a significant impact on the environment first produce an environmental impact study (EIS). The EIS must examine the environmentally sensitive features of the project and describe the actions that are to be taken to mitigate potential damage. The FERC must evaluate and approve any EIS associated with a pipeline construction project within its jurisdiction.

Depending on the project profile and its proposed route, the preparation of the EIS itself can be a major undertaking, the approval process lengthy, and the cost of implementing remedial actions significant. Regulators often ask for additional data, and delays often arise before environmental approval is granted. In some instances, when only conditional environmental approval is granted, the project's economic viability may be affected by unanticipated costs and schedule delays. Although most proposed pipeline projects encounter little or no delay as a result of environmental review, the review can become quite lengthy when approval has been delayed. gas is required, gas consumers will respond to the economics of the choice.

Another possibility is that the retention of gas customers on the system on a year-round basis could alter pricing in a fundamental way. The retention of large-volume customers on the system even during peak periods could effectively eliminate "off-peak service" and the revenues associated with interruptible service contracts. The economics of investments in incremental capacity could also be affected adversely unless the pipeline system can capture a customer base without any significant degree of demand seasonality. The lost opportunity for revenue generation during off-peak periods probably would diminish the value of infrastructure assets, affecting the returns to owners of existing infrastructure and reducing the incentive to invest in the needed capacity. This would not eliminate all capacity development, but it would tend to discourage investment in marginal projects or ones with significant seasonal load variation, which would make implementing the maximum gas conversion scenario more difficult.

Investment in equipment is another significant challenge that might discourage conversions to natural gas. Conversion from distillate-only equipment to natural gas requires either modifying the consumption equipment to burn natural gas or replacing the equipment entirely. The cost of modification or replacement of the equipment could, by itself, make the conversion economically unattractive.

Finally, although the elimination of incremental demand for distillate fuel oil from customers switching from natural gas during peak demand periods could mitigate the potential for distillate price spikes in the short term, it cannot eliminate their possibility. For example, the bulk of the demand surge in Northeast distillate markets in January 2000 seems to have been a weather-induced increase involving the regular customer base, and it is likely that prices would have risen sharply even without the additional demand as other customers switched from natural gas. Indeed, the successful achievement of the maximum switching of large-volume customers from heating oil to natural gas could actually exacerbate the potential for price spikes in the longer term by reducing the stable base of heating oil consumption. The remaining heating oil market would be smaller, consisting of the portion of current customers with a more seasonal pattern of use, and the remaining portion of the distillate market would consolidate to match the new demand. Operators would be inclined to 
reduce inventories given the smaller market, the relative swing between seasons would be larger, and inventory management would be more uncertain. As the stock cushion diminished, the market could become less prepared for sudden increases in demand or decreases in supply. 


\section{Distillate Fuel Oil Supply, Infrastructure, and Pricing}

\section{Introduction}

Distillate fuel oil markets in the United States involve two products: low-sulfur distillate, which is used as a transportation fuel (diesel) for on-highway vehicles, and high-sulfur distillate, which is used for space heating (heating oil) in the residential and commercial sectors and as a fuel for other stationary (nontransportation) applications in the commercial, industrial, and electricity generation sectors. Beginning in October 1993, the U.S. Environmental Protection Agency limited the allowable sulfur content of distillate fuel oil used as diesel fuel for on-highway trucks, buses, and cars. Although low-sulfur distillate can be used in any application, it is usually taxed as a highway fuel. The tax is imposed at the point the product "breaks bulk," or is separated from a large shipment into smaller delivery sizes, usually at a storage terminal. At the same time, high-sulfur distillate for non-highway use is dyed to identify it. Since 1993, the Energy Information Administration (EIA) has collected data separately for low-sulfur and high-sulfur distillate fuel oil..$^{89}$

The Northeast uses more high-sulfur distillate fuel oil than any other U.S. region, accounting for more than two-thirds of the total consumption of distillate fuel oil in the U.S. residential and commercial sectors in 1998. The residential and commercial sectors in the Northeast account for more than one-half of the region's distillate fuel oil use (67 percent in New England and 44 percent in the Central Atlantic), whereas in the other regions of the country residential and commercial uses make up only 7 percent of total distillate consumption. Conversely, on-highway use of low-sulfur distillate accounts for only 38 percent of total distillate consumption in the Northeast (25 percent in New England and 44 percent in the Central Atlantic), compared with 62 percent in the other regions. 90

\section{Market Structure}

The infrastructure of the distillate fuel oil industry in the Northeast begins with large distribution centers, which provide supplies to smaller distribution points that, in turn, supply thousands of retail dealers who deliver fuel to millions of homes. The large distribution centers play a central role in setting market prices throughout the region. A variety of factors have combined to make New York Harbor a product trading center for distillate fuel oil: continuous supply from a variety of sources, available storage capacity, transportation alternatives for bringing the product into and out of the area, and the participation of many market players. Because it is the physical source of much regional supply and an alternative market for companies with product to sell, including area refineries, the New York Harbor price quickly reverberates throughout the region. Boston is a second-tier trading center in terms of the world market because its sources of supply are fewer (imports and resupply from the New York Harbor area), but it is a critical distribution center for New England.

Generally speaking, independent marketers provide the gateway for distillate fuel oil supplies in the Northeast, and especially in New England. They own and operate oil storage terminals that receive supplies via tanker, barge, or pipeline. They sell to retailers and to large bulk consumers from their terminal "racks" - the superstructure of pipes, manifolds, and hoses under which trucks are loaded. Marketers offer a host of services to their customers, including lines of credit, hedging programs, ${ }^{91}$ and bid support. The wholesale market in the Northeast has undergone considerable consolidation in recent years. The largest terminals, which form the core of the region's supply network, are still operating but are owned by fewer companies. Moves toward efficiency, as well as increased environmental regulations, have resulted in closure of some smaller dealer-owned storage facilities located closer to consumers.

For more than a decade, refiners such as the major oil companies have rationalized their operations, carefully choosing their regional product markets and withdrawing from the markets where they did not have a strategic position. The large refiners that have remained in the Northeast continue to own some marketing assets, such as terminals, but the focus of their regional operations has shifted to transportation fuels (motor gasoline and diesel) rather than heating oil. The independent refiners

\footnotetext{
${ }^{89}$ ELA's petroleum supply data show supply on the basis of broad regions, Petroleum Administration for Defense Districts (PADDs). The information to quantify supply details for regions smaller than the PADDs is not generally available, although selected data series are available on a sub-PADD basis, separating PADD 1, the East Coast, into New England, the Central Atlantic, and the South Atlantic. See Chapter 1 for definitions.
}

${ }^{90}$ Energy Information Administration, Fuel Oil and Kerosene Sales 1998, DOE/EIA-0535(98) (Washington, DC, August 1999).

${ }^{91}$ Hedging programs are based on the commodity futures price of heating oil. 
that own capacity in Pennsylvania and New Jersey are active in the heating oil market, but they are bigger players in the Central Atlantic than in New England.

Retail dealers generally pick up high-sulfur distillate fuel oil from wholesale terminals in trucks. The oil is sometimes transferred to a centrally located bulk plant and from there dispatched in smaller trucks for home delivery. Many retailers, however, dispatch delivery-size trucks to the wholesale terminal, which then proceed directly to deliver the oil to homeowners and other consumers.

The dense market infrastructure in the Northeast provided several alternatives for customers to obtain supplies of distillate fuel oil in January and February 2000. Although the system did not work smoothly, ${ }^{92}$ it did meet the minimal needs of almost all customers. When a terminal in one area ran out of product because of delivery delays, there was nearly always a neighboring competing terminal that filled the gap. The "wet" terminal, with product to sell, naturally experienced a surge in demand for its barrels. While the barrels were available to all comers, historical customers generally got preferential treatment, and volumes were routinely allocated on the basis of year-earlier purchases. Furthermore, with dealers' trucks all queuing at one terminal instead of two, there were inevitably delays, and in many cases the trucks had to accept less than a full product load. The delays and the need to return to the terminal more often added further to the cost of delivery, and many customers were inconvenienced and paid higher prices than anticipated.

The delivery system in the Northeast has become tighter and tighter as competitive pressures have required that market participants store and deliver oil more efficiently. Decades ago, stocks probably would not have reached such low levels, and there would have been more inventory in smaller terminals backing up the supplies in the major terminals. Although the current system fosters lower prices in a normal market, it increases the potential for brief periods of price spikes, as seen in the winter of 1999-2000.

\section{Sources of Supply}

As shown in Figure 39, the Northeast gets its supplies of distillate fuel oil from the following sources:

- Shipments from Gulf Coast refineries via pipelines and, to a smaller extent, tankers or barges

- Shipments from Central Atlantic refineries distributed throughout the region by pipelines and barges

- Imports from offshore and foreign areas-most notably, Canada, Venezuela, and the Virgin Islands (considered by EIA to be imports) - which come either to central distribution centers such as New York Harbor and Boston, from which they are redistributed, or to smaller ports, where they meet local needs.

Figure 39. Northeast Distillate Fuel Oil Supply Sources

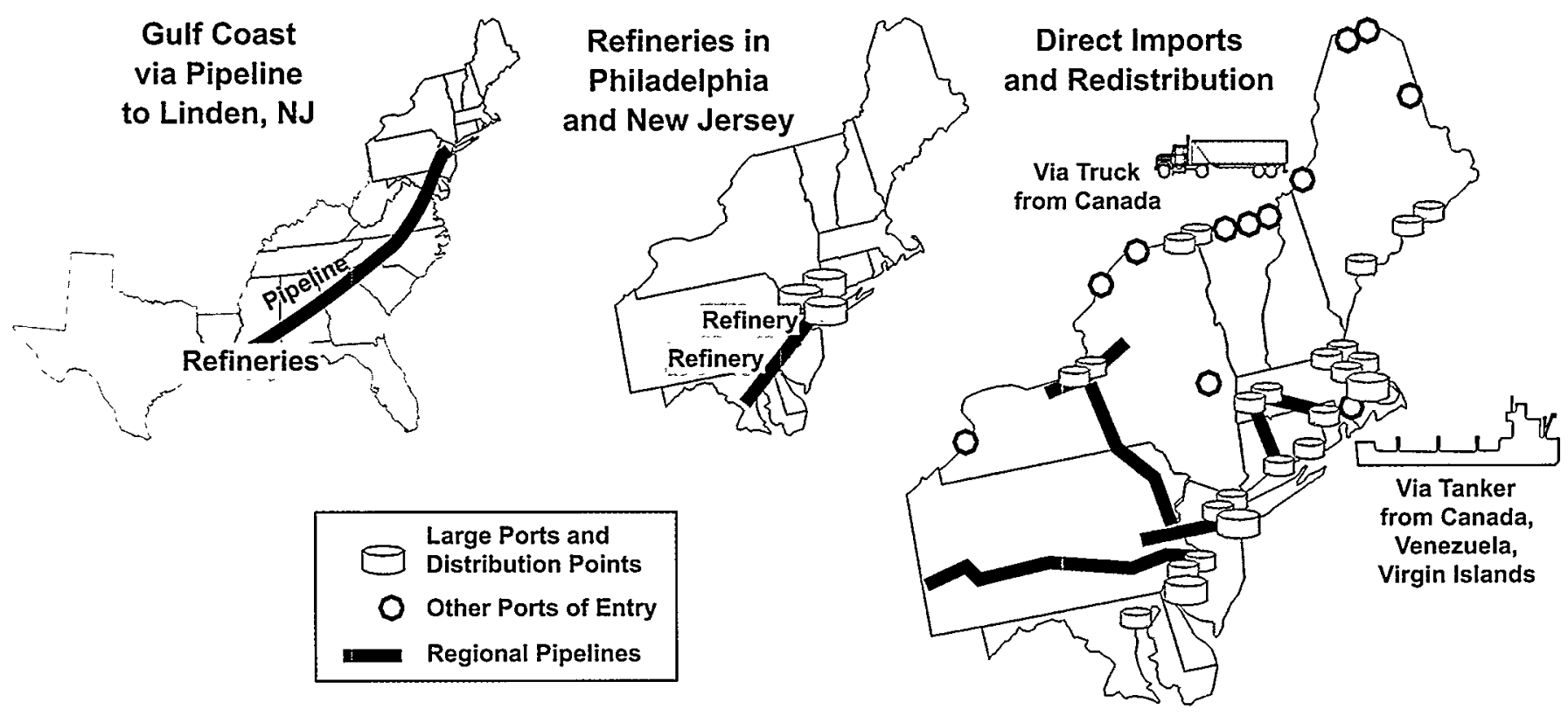

Source: Energy Information Administration, Office of Oil and Gas.

\footnotetext{
${ }^{92}$ There was widespread press coverage of supply dislocations and readjustments. See, for instance, Hartford Courant,"Supply of Oil Tightens, Weather Keeps Tanker Waiting in New Haven Harbor" (February 3, 2000), and“'Dwindling Supply Adds to State's Oil Crunch ..." (February 4, 2000).
} 
These sources provide "fresh" supplies to the region. Generally, from April to November, fresh supplies exceed regional demand, allowing for a buildup of regional stocks. From November through March, fresh supplies amount to less than the market needs, and stocks are used to make up the remainder of the requirement.

More than half, and up to 60 percent in some years, of the supply of low-sulfur distillate fuel oil to the East Coast comes from the U.S. Gulf Coast (Figure 40). Supplies of high-sulfur distillate rely about evenly on shipments from other regions, such as the Virgin Islands, and on local refineries. Imports make up a small but significant percentage of supply for both products. The line for "Product Supplied" in Figure 40-a proxy for consumption-shows stock buildups in the years when the bars are higher than the line and stock drawdowns when the bars are lower than the line, as in 1999.

The monthly pattern of annual supply to the East is shown in Figure 41. For low-sulfur distillate fuel oil, there is little seasonal variation in supply, with only a few percentage points difference from the lowest to the highest month. In contrast, for high-sulfur distillate fuel oil, the volume of product supplied in the highest months is 2.5 times the volume in the lowest months. Each of the supply components increases during the peak months, and the importance of stocks is clear. On average over the 1995-1999 period, stock drawdowns contributed 20 percent of the supply of high-sulfur distillate fuel oil in the winter heating season.

\section{Receipts from the U.S. Gulf Coast}

The East Coast receives supplies of distillate fuel oil from the Gulf Coast via pipeline and waterborne shipments (tankers and, more commonly, barges). Of the net supplies from other regions shown in Figure 41 (approximately 385,000 barrels per day of low-sulfur distillate and 230,000 barrels per day of high-sulfur distillate), pipeline supplies make up the vast majority. Figure 42 shows "gross" shipments to the East Coast from the Gulf Coast (i.e., without accounting for any shipments moving in the other direction). About 80 percent of the low-sulfur supplies and more than 85 percent of the high-sulfur supplies are shipped via pipeline. Supplies leave the Gulf Coast on the Colonial Pipeline and the Plantation Pipe Line. The two lines follow roughly the same route, with the Plantation's terminus in the Washington, DC, area and Colonial's terminus in Linden, New Jersey. About half of the East Coast's on-highway (low-sulfur) distillate fuel oil is consumed in the South Atlantic. Hence, a considerable portion of the pipeline supply from the Gulf Coast is delivered into PADD 1 in the South Atlantic States, not in the Northeast.

The tanker and barge movements from the Gulf Coast to the East Coast are now almost exclusively shipments across the Gulf of Mexico to Florida, which has no

Figure 40. Distillate Fuel Oil Supply on the East Coast by Source, 1995-1999

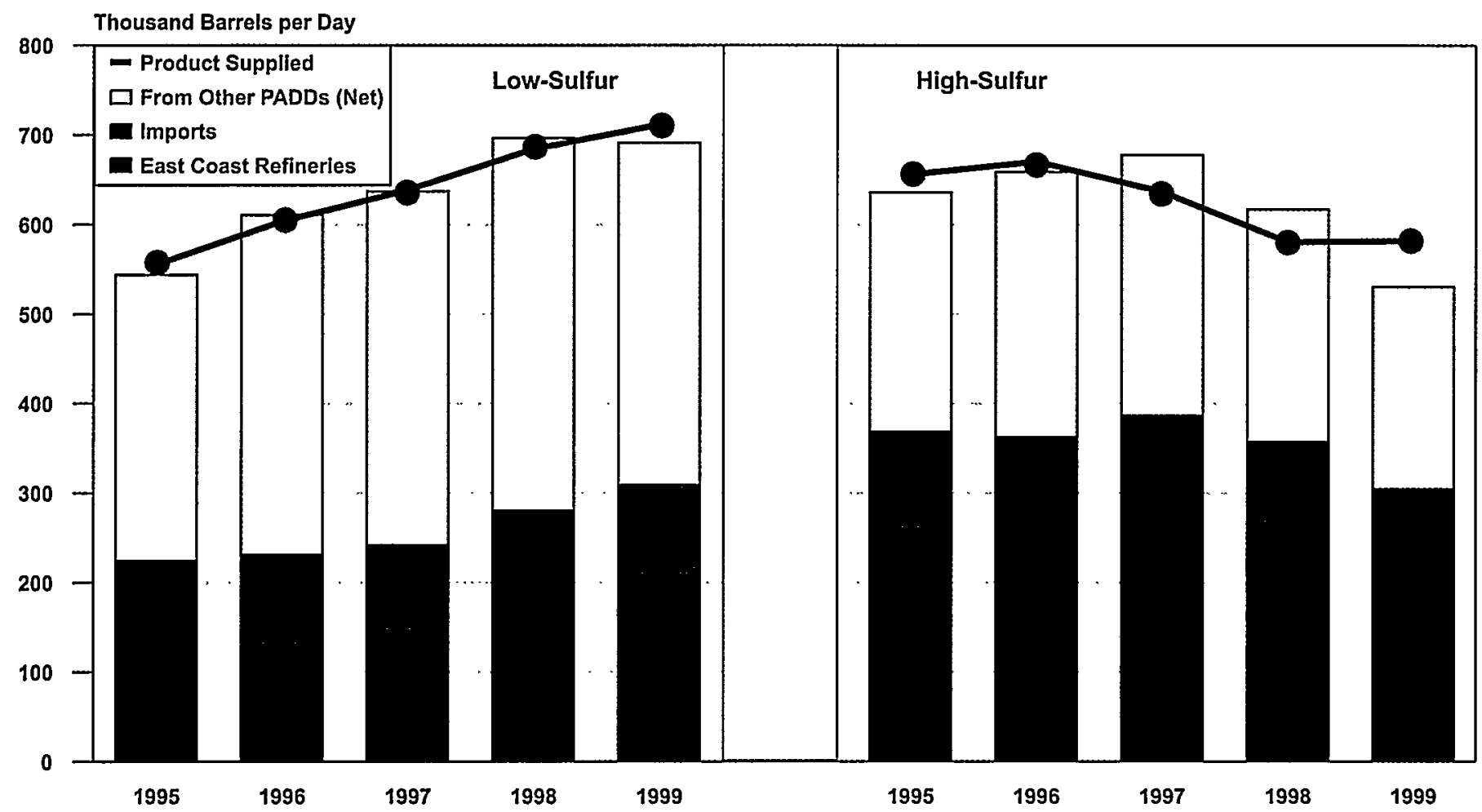

Sources: Energy Information Administration, Petroleum Supply Annual, DOE/EIA-0340, Volume 1 (Washington, DC, 1995-1998 issues); and Petroleum Supply Monthly, DOE/EIA-0109(2000/02) (Washington, DC, February 2000), Table 9. 
Figure 41. Average Monthly Distillate Fuel Oil Supply on the East Coast by Source, 1995-1999

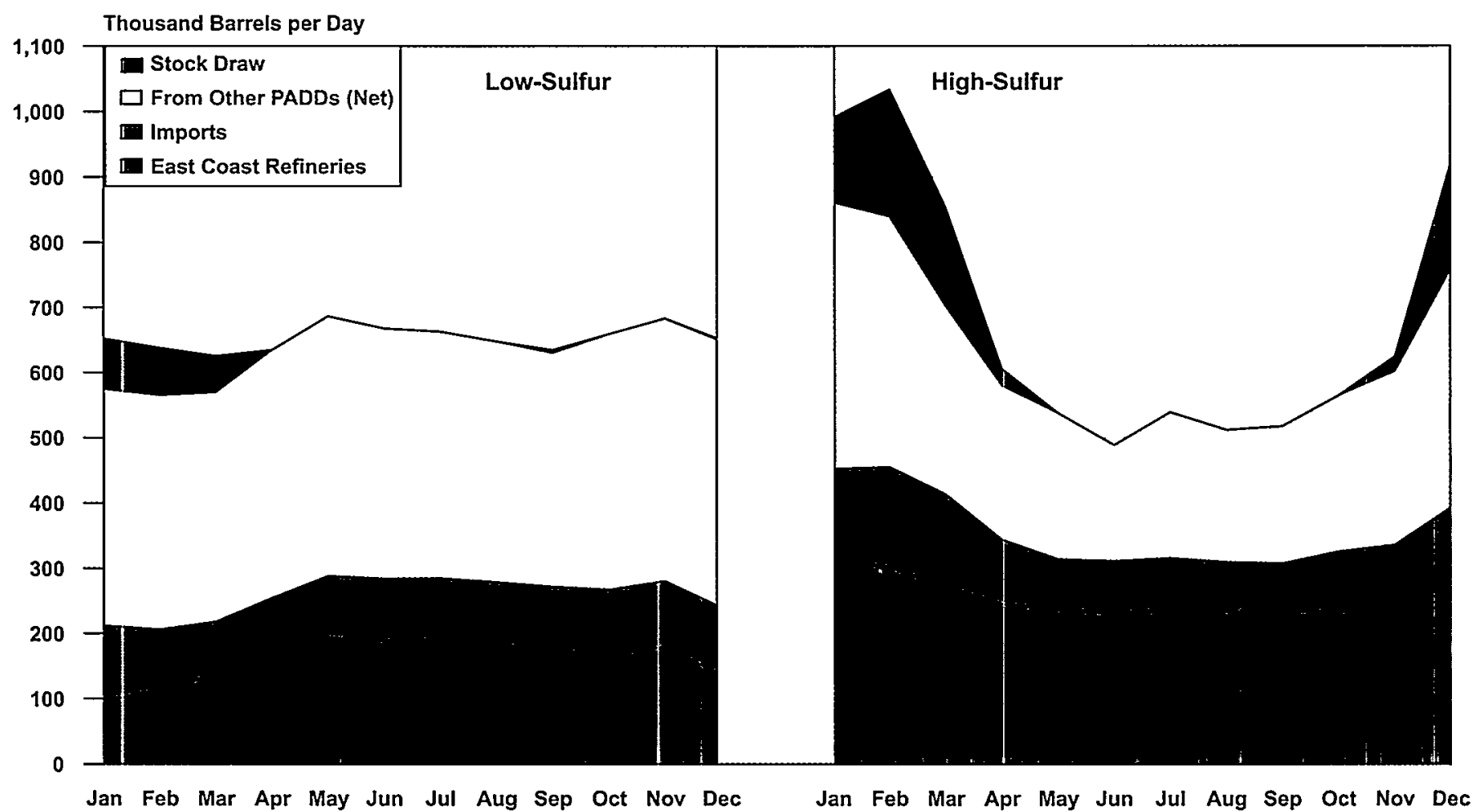

Sources: Energy Information Administration, Petroleum Supply Annual, DOE/EIA-0340, Volume 2 (Washington, DC, 1995-1998 issues), Table 5; and Petroleum Supply Monthly, DOE/EIA-0109 (Washington, DC, various issues), Table 8.

Figure 42. Distillate Fuel Oil Supplied to the East Coast from the U.S. Gulf Coast by Mode of Transport, 1995-1999

Thousand Barrels per Day

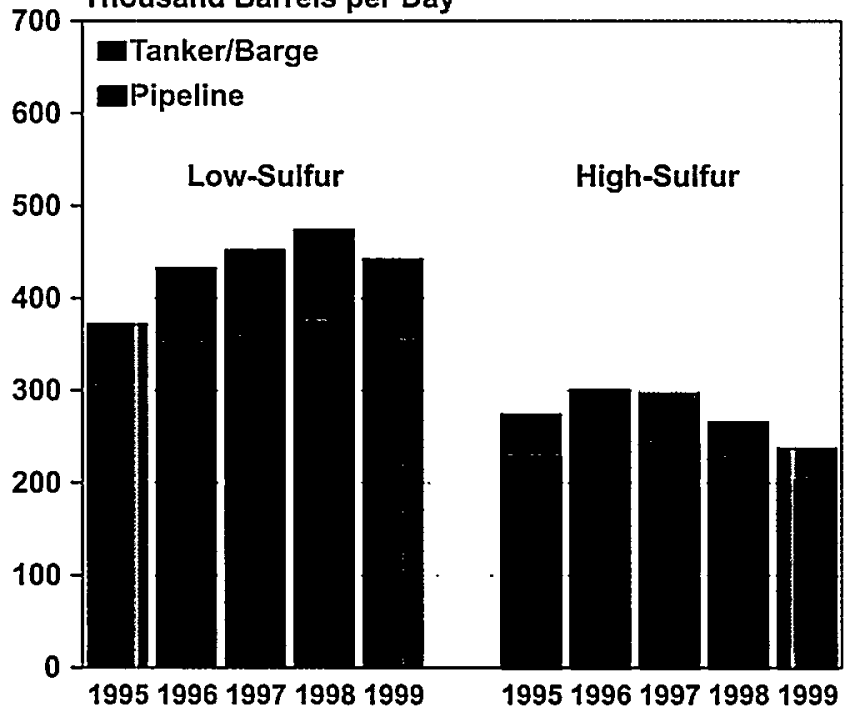

Sources: Energy Information Administration, Petroleum Supply Annual, DOE/EIA-0340, Volume 1 (Washington, DC, 1995-1998 issues), Tables 33 and 34; and Petroleum Supply Monthly, DOE/EIA-0109 (Washington, DC, various issues), Tables 54 and 55. interstate pipeline connections. At times in the past, tanker and barge shipments of high-sulfur distillate to the Northeast have briefly soared, in response to market economics. In late 1996 and early 1997, for instance, when heating oil stocks were quite low, tanker and barge shipments from the Gulf Coast to the Northeast ran at 40,000 to 50,000 barrels per day for several months. In 1999, they were less than 5,000 barrels per day, because the market did not require these high-cost supply supplements. (Throughout 11 months of 1999, heating oil stocks in the Northeast were high, not low, by historical standards.) The East Coast also receives minor volumes of distillate from PADD 2, the Midwest.

\section{Supplies from Area Refineries}

East Coast refineries supplied about 37 percent of the East Coast's high-sulfur distillate fuel oil in 1999, a significant decline from the 47-percent share in 1998. The difference is a reflection of the overall market in 1999, when high inventories and low margins discouraged additional output. According to EIA's Petroleum Supply Annual, there were 14 operating refineries in PADD 1 as of January 1, 1999. The 11 refineries in the Delaware to New York City corridor accounted for 95 percent of the capacity of 1.5 million barrels per day. Supplies from area refineries are distributed throughout the Northeast coast by barge and are transported to inland Pennsylvania and New York via the Buckeye Pipeline system. 
The refineries in the Northeast, like U.S. refiners in general, have their peak operations in the warmer months, supplying gasoline and diesel for seasonal consumption and high-sulfur distillate (heating oil) for seasonal stock builds. Refinery production of high-sulfur distillate fuel oil increases during the winter months, however, when demand for home heating oil is at its annual peak. The sudden unavailability of steady supply from area refineries was a factor in the price runup of early 2000. Low margins encouraged refiners to undertake routine maintenance in January, and when the supply situation deteriorated, the lack of ready capacity combined with unexpected equipment outages prevented refiners in the Northeast from responding rapidly with production increases.

\section{Imports}

According to ELA data, imports supply about 15 percent of the distillate fuel oil on the East Coast. In recent years, the major sources of distillate fuel oil imports to the Northeast have been Canada (32 percent of the Northeast's 1999 imports), Venezuela (23 percent), and the Virgin Islands ( 37 percent). ${ }^{93}$ In 1999, the refinery in the Virgin Islands began to be operated by a joint venture between Amerada Hess (the plant's original owner) and the Venezuelan oil company, Petroleos de Venezuela. In New England, the volume originating in the Virgin Islands rose while the volume originating in Venezuela fell from 1998 to 1999. Although distillate fuel imports to New England that originated in Venezuela declined by about 10 percent, the share of Venezuelan high-sulfur distillate imports declined even more, from 75 percent in 1998 to 60 percent in 1999 (Table 12). The shift to low-sulfur distillate in January and February 2000 combined was even more pronounced, rising from 46 percent in 1999 to 74 percent in 2000. The share of Venezuelan distillate fuel imports to the East Coast rose slightly, from 24.5 percent in 1998 to 24.9 percent in 1999. In the Central Atlantic, 1999 import volumes from the Virgin Islands fell. (Venezuelan supplies of distillate fuel oil into the Central Atlantic are very small.) Imports into New England often show a distinct seasonal swing, especially for high-sulfur distillate (Figure 43). The Central Atlantic, with lower imports, is also more focused on low-sulfur supplies in most years.

A few ports dominate the import trade into the Northeast. In 1999, Boston was the largest import point in New England, at 36,000 barrels per day, followed by New Haven (20,000 barrels per day), Portland, Maine $(15,000$ barrels per day), and Portsmouth, New Hampshire (14,000 barrels per day). Other ports in the region receiving more than 2,000 barrels per day included Providence, Rhode Island; New London, Connecticut; and Searsport and Belfast, Maine. Barges and trucks redistribute supplies from these large terminals and distribution centers. In addition, pipelines carry product inland from New Haven (Buckeye) and Providence (Mobil) to the Springfield, Massachusetts, area. In the Central Atlantic, the big ports are in the New York Harbor area. New York and Perth Amboy, New Jersey, together received 22,000 barrels per day of distillate fuel oil in 1999 (a significant decline from 1998 volumes, as noted earlier).

Some of the ports and channels in New England could be dredged and deepened to allow larger vessels to

Table 12. Distillate Fuel Imports to New England Originating In Venezuela, 1998-2000 (Thousand Barrels)

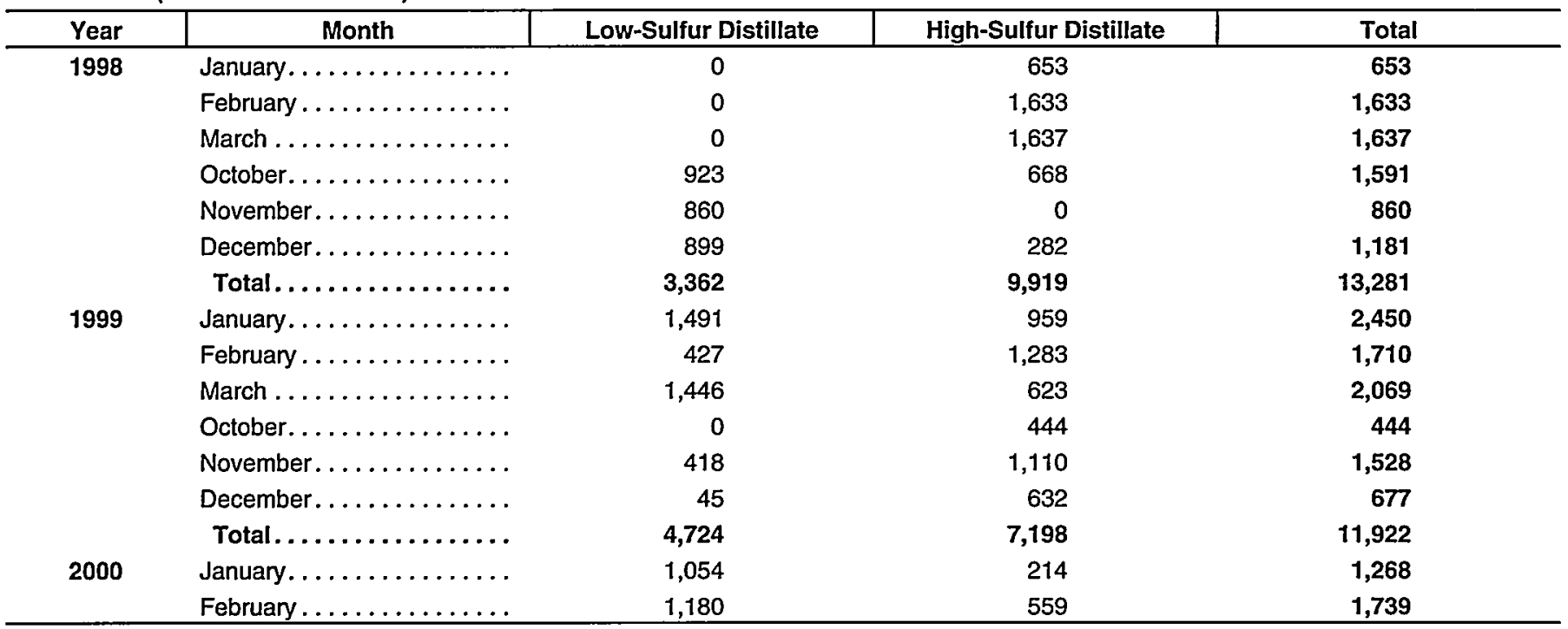

Source: Energy Information Administration, Form EIA-814 (data available on the EIA web site, www.eia.doe.gov).

\footnotetext{
${ }^{93}$ Although the Virgin Islands are officially part of the United States, EIA data classify petroleum shipments from the Virgin Islands as imports.
} 
Figure 43. Quarterly Imports of Low-Sulfur and High-Sulfur Distillate Fuel Oil into the Northeast Region, 1995-1999

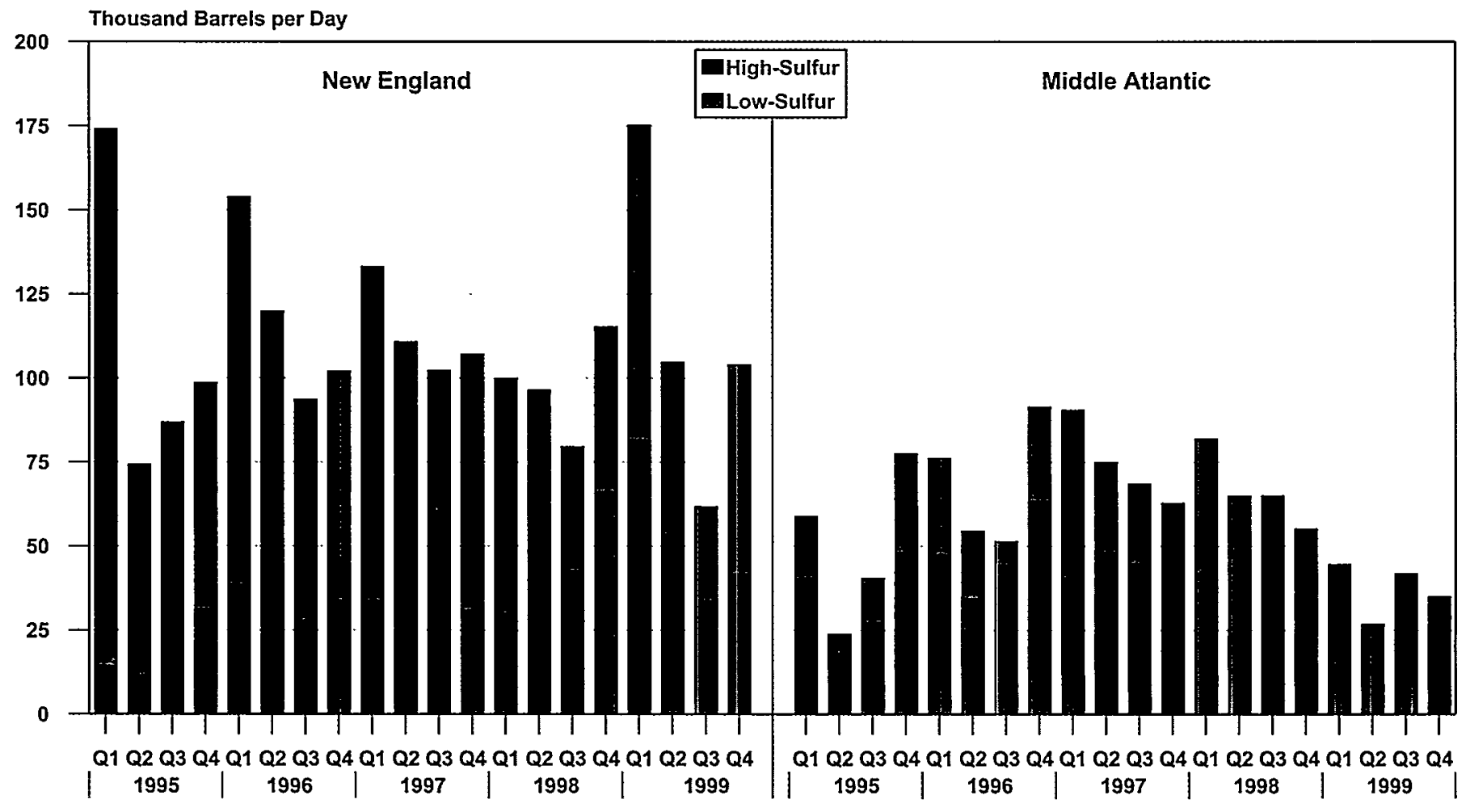

Source: Energy Information Administration, Form EIA-814 (data available on the EIA web site, www.eia.doe.gov).

carry distillate fuel oil, and perhaps to allow larger tankers to dock and unload. Dredging is typically expensive, because both the ports and the channels leading to and from them must be dredged to be effective. Larger tankers would require longer to unload, and that would partially offset some of the gains from having larger deliveries. In the winter of 1999-2000, however, both tankers and barges were unable to dock, and the problems were not limited to shallow-draft ports or ports with significant channel limitations. Under less challenging weather conditions, New England ports have reached import levels of 175,000 per day in the first quarter of 1995 and 1999 (Figure 43).

Other large coastal entry points in the Central Atlantic include Baltimore, Maryland, and Newark, New Jersey. In addition to the coastal imports, supplies from Canada enter at a variety of pipeline points along the New York, Vermont, New Hampshire, and Maine borders. In 1999, there were 30 entry ports for distillate imports coming into the Northeast, with the smaller volumes going to diverse locations, where they are often critical to the local supply picture.

\section{Regional Distribution}

The Northeast's distillate fuel oil market has a routine resupply chain, as described above. Among the regular supply sources, pipeline shipments from the Gulf Coast generally have the longest transit time, taking from 14 to 20 days for the run from Texas to New Jersey. Waterborne imports arriving via tanker have shorter transit times, with Venezuela and the Virgin Islands 5 to 7 days away. The shipments are carefully planned in advance so that they arrive at regular intervals. Companies employ a variety of mechanisms to enhance their supply flexibility, such as time exchanges. ${ }^{94}$ The transit times illustrate, however, that when the interstate supply system is stretched, immediate incremental supplies are available only from local inventories.

The Northeast receives its distillate fuel oil at many points along the coast and along the border, but the largest volumes come to a few large ports and are redistributed from there. Barges move supplies from New York Harbor to Long Island, northward up the Hudson, and northeastward along the Connecticut coast to Rhode

\footnotetext{
${ }^{94}$ Time exchanges occur when one company provides a quantity of a product to another with an agreement that it will be repaid in kind at a later date.
} 
Island and on to Massachusetts. Barges based in Boston and other oil-handling ports also move supplies along the coast. Movements of the barges are carefully choreographed to minimize costs and maximize the use of capacity available under the Jones Act. ${ }^{95}$

A delay in loading or unloading or in transit time is quickly felt in the supply chain. With the barge fleet in the Northeast generally operating close to capacity in the peak winter periods, it is a challenge to compensate for any delay. When movements are constrained by bad weather, however, even extra capacity cannot provide relief. Furthermore, the tankers that carry oil imports directly to coastal ports are unable to come into port safely during stormy weather with high seas and high winds.

During the coldest period of January 2000, stormy weather and ice-covered rivers and harbors delayed resupply deliveries, with Coast Guard ice breakers working at capacity to keep up. The fact that barges were weather-bound during the third week of January was a central factor in the price spike. Before that point, the New York Harbor spot prices for distillate fuel oil did not reflect a market concerned with short supply, in spite of the very low inventory levels. The cold weather and its attendant demand surge coincided with the interruption in barge and tanker traffic, breaking the critical pace of resupply. As a result, spot prices were quickly bid up in the regions supplied by river barge, like the Hudson River.

\section{Stocks and Storage}

The decision to store oil is a complex one. The market's present need for oil is reflected in the current price. High prices indicate that the market needs more oil, and needs it now. The forward price curve (the price of oil in the future as compared to the price today) provides additional information. A market in which the price for future delivery is lower than the current price discourages storage. Market participants are reluctant to hold inventories or add to them when they are expected to lose value in the future. As the heating oil season approaches, typically in the summer and early autumn, it is common to see a forward price curve that reflects higher prices in December and January than in the following September and October. Using the futures market, a market participant can "lock in" the difference (spread) between the current price and the New York Mercantile Exchange (NYMEX) futures price during the heating season, covering the cost of storage and the cost of money for the purchase.

The unusual-even historic-stock drawdown that took place in the Northeast in December 1999 and January 2000 was precipitated by a variety of factors, as described in Chapter 2 of this report. Importantly, the forward price curve indicated that the product would be worth less in the future. Thus, a ready buyer at the market price was welcome. With natural gas buyers making the economic decision to switch to oil, there were many such buyers available.

ELA collects data on "primary" inventories, the stocks held by refiners, pipelines, and in terminals with large capacity or with access to waterborne or pipeline supplies. In addition to primary inventories, secondary inventories are held by retailers or distributors, and tertiary inventories are held by consumers; however, data on secondary and tertiary inventories are not collected by EIA

Secondary inventories of distillate fuel oil are largely held in bulk plants, the small tanks that formerly dotted the landscape throughout the Northeast, providing the convenience of shorter truck runs for the dealers who owned them. For the market as a whole, they provided an additional cushion and flexibility for local exchanges to smooth out delivery bumps. As the retail industry consolidated, however, owners sought to enhance the efficiency of their operations by closing underutilized storage depots. The trend was clearly accelerated by more stringent environmental rules and the increased business risk the rules presented in the event of tank failures. With no new storage facilities being constructed, there has been a net loss of secondary storage capacity over the past decade. Comprehensive data for the Northeast region are not available, but data from the New York State Department of Environmental Conservation provide an illustration. The agency's data on facilities such as bulk storage plants indicate that there has been a drop of more than 10 percent in the number of storage facilities with 1,100 to 400,000 gallons capacity, and in the capacity at such sites, in the past 2 years alone.

Tertiary stocks held by consumers are also an important part of the distillate fuel oil supply system. For example, home heating oil customers, on average, have about 30 days of supply in tank, a much higher supply relative to consumption than the rest of the industry. For those customers not on a "will call" status, a dealer with an automatic delivery program in place uses degree-days, the characteristics of the house, and consumption history to calculate when a customer's tank needs to be filled. The dealer tries to optimize deliveries, filling the tank before it gets too low but timing the delivery so that the tank can take enough to support the cost of the delivery. (Frequent, small deliveries rapidly multiply the cost of servicing the account without providing any benefit.)

For a typical 275-gallon tank, 78 gallons would be the optimum refill trigger, 182 gallons the optimum fill, and 260 gallons the effective maximum capacity. Because a

${ }^{95}$ The Jones Act requires that U.S. flagged ships transport shipments between U.S. ports after international ships are off-loaded. 
typical single-family home consumes about one-eighth gallon of oil per heating degree-day, during a normal January in New England the homeowner would have about 30 days between fills (after allowing for water heating consumption). If the pattern followed the optimum, the homeowner would still have 15 days of supply remaining at the time of the refill. Because of this fill-and-draw pattern, it is unlikely that many homeowners received more than one delivery at the January 2000 spike price.

During the January price runup, some dealers delivered "short" (i.e., did not completely fill the tank) as a means of allocating available supplies and preventing homeowners from receiving excessively high bills during the price spike, ${ }^{96}$ which was hoped to be only temporary. It would also raise the cost of delivery, but for homeowners not participating in a price cap or fixed price agreement it would have meant that the next delivery might be at lower prices.

The inventory patterns of large-volume customers have also played a role in recent price spikes (December 1989, January 1994, and January/February 2000). Largevolume customers do not always carry adequate inventory to cover their needs during unusual circumstances, such as the January/February 2000 cold snap. Some turn to distillate fuel oil at times when their natural gas supplies have been interrupted as part of their service agreements. Others turn from natural gas to distillate fuel oil for economic reasons. The sudden entry of these buyers into the market has been a contributing factor in past price spikes.

\section{Pricing and Contracts}

Prices in distillate fuel oil markets respond quickly to changes in supply and demand. First, spot prices reflect the outcome of the ongoing "auction" in the marketplace. The routine bid-and-ask process between buyers and sellers quickly reflects the need for more supply or a supply glut. The prices at which once-only transactions are taking place in the big product trading centers such as New York Harbor become known quickly via electronic reporting services and bulletin boards, print media, trade publications, and industry associations. The price of commodity futures is a universally available indicator of the expected balance between supply and demand.

During the price spike of January-February 2000, spot prices for available supplies far outpaced the futures price. At the peak, the price for "prompt" barrels was $\$ 1.00$ per gallon higher than the futures price. The magnitude of the differential was as unexpected as it was historic. During the supply crunch of late January, deliveries under the February 2000 contract were still weeks away. After the expiration of the February contract on January 31, volumes would not be deliverable again until early March, under the March 2000 contract.

Spot prices in the New York Harbor are a good proxy for the prices paid by large suppliers such as independent marketers. The New York Harbor spot prices quickly reflect increases in the prices paid on the spot market for immediate supply or decreases in prices when supplies exceed demand. Thus, a retail dealer who is detached from the New York market may have to pay the current New York Harbor spot price and pass it on to residential consumers.

Risk management mechanisms, such as hedging and price caps, are used routinely in distillate fuels markets, and retail dealers offer a variety of pricing programs to their customers. According to a voluntary survey of full-service dealers routinely conducted by the Massachusetts-based accounting firm of Gray, Gray, \& Gray (Table 13), 98 percent of the dealers in the Northeast who responded to the survey offer "budget payment plans" to their customers. Such programs are also called "levelized" plans. Typically, these plans extend from July to May, allowing customers to make equal payments toward anticipated heating oil bills over the months. Under- and overpayments are settled at the end of the period.

\section{Table 13. Pricing Programs Offered to Consumers by Heating Oil Retailers in Northeast States, 1999 (Percent of Dealers Responding)}

\begin{tabular}{|c|c|c|c|}
\hline State & $\begin{array}{c}\text { Guaranteed } \\
\text { Pricing } \\
\end{array}$ & Price Cap & $\begin{array}{c}\text { Budget } \\
\text { Payment } \\
\text { Plan } \\
\end{array}$ \\
\hline Connecticut ...... & 70 & 45 & 90 \\
\hline Maine ......... & 86 & 72 & 100 \\
\hline Massachusetts.... & 59 & 56 & 94 \\
\hline New Hampshire... & 86 & 64 & 93 \\
\hline Rhode Island ..... & 57 & 72 & 86 \\
\hline Vermont........ & 78 & 56 & 100 \\
\hline Delaware ........ & 0 & 50 & 100 \\
\hline Maryland ........ & 38 & 50 & 100 \\
\hline New Jersey ...... & 28 & 28 & 100 \\
\hline New York........ & 44 & 56 & 92 \\
\hline Pennsylvania ..... & 47 & 45 & 92 \\
\hline Virginia.......... & 0 & 0 & 100 \\
\hline Overall......... & 55 & 54 & 98 \\
\hline
\end{tabular}

Source: Gray, Gray, \& Gray, Oilheat Survey 1999, web site http://graymail.com/news/survey99.pdf. The numbers are based on responses from nearly 500 dealers.

\footnotetext{
${ }^{96}$ Testimony of Peter D'Arco, SJ Fuel, Before the House Committee on Commerce, Subcommittee on Energy and Power, U.S. House of Representatives (March 9, 2000).
} 
Budget payment plans have the significant advantage of allowing the customer to anticipate a stable bill, and because the payments that would be due in cold months are averaged with those for warm months, the final accounting usually does not result in a large additional payment. Even if an additional payment is due, the consumer has more time to arrange finances to reduce the hardship.

More than half of the dealers in the survey also offered guaranteed pricing and/or price cap programs, which would have allowed their customers to avoid the spike price altogether; however, the extent to which customers participate in the programs is not known. In the New England States, the lowest percentage of retailers offering guaranteed price programs is 57 percent of the respondents in Rhode Island, compared with 86 percent in both Maine and New Hampshire, 78 percent in Vermont, and 70 percent in Connecticut. Although there were a few stories of dealers who did not honor fixed-price contracts during the January 2000 price runup, they are thought to be a small fraction. ${ }^{97}$ Dealers who took losses because they left themselves vulnerable to price increases in their supply acquisition strategies are likely to make modifications in the future to cover their own risks.

Retailers offering fixed-price sales to customers must cover the costs of their own purchases. Just as retailers offer programs to their customers, wholesalers often offer risk management programs to retailers. For companies using the necessary mix of futures and options, ${ }^{98}$ wholesale prices remained capped even during the worst of the spike. These programs represent insurance, and as in all insurance decisions, there is a tradeoff between the comprehensiveness of coverage (and hence the cost) and the risk of an unanticipated cost event. The volumes covered by such a program are thus seldom all of the company's supply, because the transaction cost is prohibitively high. A retailer, for instance, might lock in or cap the cost side only for those volumes that will subsequently be delivered under a fixed (or capped) price contract. Thus, the high delivery volumes associated with exceptionally cold weather are unlikely to be covered.

\section{Market Implications of Reducing Reliance on Distillate}

Two approaches have been suggested to reduce the potential for future price spikes in Northeast distillate fuel oil markets: (1) switching large-volume, year-round users of distillate fuel to natural gas and (2) preventing energy customers with interruptible natural gas service from entering the distillate market during periods of high demand. The first approach would reduce the market base, and the second would reduce peak demand levels.

Switching large-volume users of distillate fuel oil to natural gas or another energy source would result in a smaller overall distillate market, with declining economies of scale. Initially, there could be excess supply, leading to a decrease in prices, which could lead to a consolidation of the distillate industry. For example, fewer barge-size deliveries would be needed, which could lead to a reduction in the size of the barge fleet. Similarly, fewer terminals and trucks would be needed, scaling the delivery infrastructure to the size of the market. Many infrastructure costs are fixed, however, and not easily scaled. Spread over a smaller volume, per-unit costs are likely to increase as the market size decreases.

Removing large-volume, year-round users of highsulfur distillate from the market would also increase the seasonal swings in demand for the product, because the remaining market would consist primarily of consumers who use distillate for space heating. Reducing the size of the market would likely result in the closing down of terminals and companies. Rather than a reduction in volume handled by all terminals, the likely result of a smaller market would be consolidation of terminals in efforts to maintain economies of scale in their operation. Because retail margins are often very thin, some companies probably would shut down. The result would likely be fewer companies operating fewer terminals with fewer barges and trucks. As a result, when another bout of cold weather or supply disruption occurred, the consequences might be just as severe, and possibly worse, than the situation where the large-volume customers

\footnotetext{
${ }^{97}$ For instance, officials in the office of the Attorney General of Massachusetts were quoted as saying that they had received complaints about six companies that had imposed surcharges on fixed-price contracts (see Boston Globe, "Worcester Heating Oil Company to Repay Customers It Surcharged" (February 26, 2000)). While the story does not cite the number of heating oil dealers active in the State, the dealer's trade association in Massachusetts has some 700 members. The case of the Worcester dealer cited in the article's headline ended with the dealer making restitution to its 6,000 fixed-price customers and donating $\$ 10,000$ for low-income heating assistance; the dealer in question has stated publicly that the surcharge was allowed by the contract. The Attorney General of Rhode Island received complaints on nine companies, all of which finally honored the fixed price (see Providence Journal, "Oil Dealers Will Honor Contracts" (February 18, 2000)).

${ }^{98}$ Companies can purchase an option contract above a futures contract strike price as a hedge that, if the price exceeds the strike price before the option expires, they can either sell the option for a profit or ask for delivery at the lower strike price. However, if heating oil futures fall below the strike price at the expiration of the option contract, the option expires and the option seller keeps the premium.
} 
remained in the distillate market. Fewer companies could also mean less competition, which could result in higher prices.

The second approach-preventing energy customers with interruptible natural gas service from entering the distillate market during periods of high demand-probably would mitigate price surges in the heating oil market, because suppliers would be better able to anticipate seasonal demand for distillate fuel in the winter months and plan storage and deliveries accordingly. In recent years there has been a movement toward a "just-intime" inventory and delivery system that reduces excess storage capacity and reduces costs. In normal times, the system works fine, but when demand rises rapidly beyond the anticipated peak, infrastructure and supplies are stretched. The unanticipated entrance into the market of large-volume customers, due to natural gas supply interruptions, causes even greater strain on the distillate supply system. Preventing those customers from entering the market would lessen the strain on distillate supplies. However, seasonal demand surges by the "regular" distillate customers would still be as unpredictable as winter temperatures. Moreover, as discussed in Chapter 4 of this report, curtailing interruptible natural gas service could have severe consequences for the region's natural gas market.
Interruptible natural gas consumers, ${ }^{99}$ by virtue of their interruptible status, typically receive favorable gas service rates after they show that they can switch to an alternate fuel. ${ }^{100}$ Gas deliveries can be interrupted under certain circumstances, such as when temperatures fall below a given threshold or operating conditions on the pipeline require it. Such customers generally must either have on-site storage capability for their alternate fuel, maintain a nearby storage capability operated by a third party, or be prepared to shut down operations when natural gas service is curtailed. Natural gas utilities in New Jersey and New York, for example, require through their tariffs that their interruptible gas customers have an alternate fuel capability. Unfortunately, the stocks or inventory maintained by end users (tertiary storage) are typically not surveyed, and no definitive statement can be made about their inventory levels during critical periods of the 1999-2000 winter. Information from the New Jersey Board of Public Utilities suggests that at least a few large-volume gas-distillate switchable consumers may have gone into mid-January 2000 with distillate inventories that were lower than normal. ${ }^{101}$ The total volume of gas service interrupted in New Jersey in January 2000 was equivalent to a maximum of 741,000 barrels of fuel oil.

\footnotetext{
${ }^{99}$ Interruptible customers are those whose gas service can be curtailed to assure gas service to firm-service customers.

${ }^{100}$ Requirements for alternate fuel capability and minimum maintenance levels of alternate fuel supply (e.g., 10 days worth) vary from utility to utility and normally are integrated into gas utility tariffs. Brooklyn Union's new tariff for large-volume users, for example, requires a minimum 10-day supply; most other New York State gas utilities specify only the requirement to maintain an alternate fuel capability. The Public Utility Commissions or their equivalent endorse these gas utility practices or requirements through their acceptance of the gas utilities' tariffs. Enforcement is left entirely up to the gas utilities.

${ }^{101}$ State of New Jersey, Board of Public Utilities, Board of Public Utilities Heating Oil Review (February 23, 2000), web site www.state.nj.us/ $\mathrm{bpu} / \mathrm{wwwroot} / \mathrm{communication/Govrpt.PDF}$. At the hearings, New Jersey gas utilities noted that some of their interruptible gas customers were given their normal interruption notice (about 8 hours) to stop using gas but chose to stay on natural gas despite agreed-upon heavy price penalties for continued use-as much as 10 times their normal gas rates and well above the distillate fuel oil price. This suggests that at least some of those interruptible customers had below-normal alternate fuel inventories and had to continue operating with natural gas, even at much higher costs. Hearings have been held by the Board of Public Utilities on the cause of the distillate fuel oil price spikes, and final recommendations are expected by the end of May 2000.
} 


\section{Policy Initiatives for the Northeast Heating Fuels Market}

The problems in the Northeast heating fuels market during winter 2000 were the result of infrequent, short-term events that occurred in the context of the region's unique energy market and concurrent tight worldwide oil supplies. Because of events in the world oil market during 1999 and a recent history of warm winters, there were few incentives for building deep inventories of heating oil in the Northeast. When severe weather occurred in late January 2000, causing a surge in heating oil demand and disrupting normal winter transportation routes, already low inventories were reduced further. Home heating oil consumers throughout the region faced sharp increases in their bills. Retail delivery companies faced problems obtaining supply, keeping trucks in operation, and getting funds to purchase new inventory. At the same time, the demand for natural gas in the region raised the price of gas and stretched the capacity of some pipelines. Customers with distillate fuel burning capability and interruptible contracts either chose or were asked to switch to their alternative fuel; and when they entered the distillate fuel oil market, prices were pushed further upward.

The experience of the 1999-2000 winter has not been the norm for the region. For the most part, over the past 20 years heating oil and gas markets in the Northeast have operated well for consumers. Distillate fuel oil has provided reliable service and good economic value to its consumers in all end-use sectors. Heating oil has retained most of its residential and commercial customers, although demand in the Northeast has declined slightly.

Forecasts for the next 20 years indicate further declines in distillate demand across the residential, commercial, and electricity generation sectors. Demand for natural gas in the region has grown moderately over the past 20 years but is expected to grow rapidly in the next 5 to 20 years, especially in the electricity generation sector. Increases in natural gas demand are expected in both the Middle Atlantic and New England regions and, most notably, in New England where new supply is anticipated. In the Middle Atlantic, natural gas consumption already exceeds heating oil consumption in all sectors.

As regional consumption of energy grows in the future, the Northeast is expected to remain highly dependent on complex, long-distance transportation and distribution systems to supply area customers with both fuels. Given the limited capacity for Middle Atlantic refinery production and the long supply chains from other producing areas, Northeast heating oil suppliers and customers usually build seasonal inventories at their terminals, bulk plants, and home or business storage tanks. Real-time transmission of natural gas at levels determined by pipeline capacity and contract terms accounts for most of the area's gas supply. The nearest underground storage facilities for natural gas are in Pennsylvania and New York. Opportunities for natural gas storage in New England are limited at present to relatively high-cost, small-volume supplies of liquefied natural gas (LNG).

The analysis in this report suggests that economic incentives and opportunities are limited for large consumers of distillate fuel oil in the Northeast to either (a) switch to other fuels during peak demand periods using existing equipment or (b) convert to a different fuel in a one-time change of equipment. The volumes that might be part of short-term fuel switching are limited because only a small portion of consumers have dual-fuel firing capability. Nonetheless, the possibility of fuel switching does exist now and may grow in the future if economic incentives suggest that option. A critical economic determinant would be growing expectations that the relative cost of natural gas will periodically be higher than the price of distillate fuel oil or that natural gas demand will periodically exceed supply capacity. A separate study is being conducted to determine the roles of fuel switching and interruptible contracts in the distillate fuel oil price increases in winter 1999-2000 and to identify possible solutions for the future.

The primary reason that prospective volumes for conversion are small is that the industrial and power generation sectors are already relying extensively on natural gas. Together they accounted for less than 10 percent of regional distillate consumption in 1997. (In addition, about one-half of the industrial use of distillate fuel was for on-site or off-road transportation.) The present analysis also notes that extensive conversion from distillate fuel in these sectors might remove a stable base of heating oil consumption and add to the seasonal variability in demand. Greater seasonal variability would make inventory management more difficult for terminals and bulk plants and would also increase the seasonal swings in demand on the transportation system. Conversion to natural gas would also have significant effects on gas consumers, beginning with investments to acquire new gas equipment and probably including commitments to firm gas supply and transportation contracts. 


\section{Basis for a Policy Mix}

Distillate fuel oil will remain a significant part of winter heating demand in the Northeast over the next few years. At the same time, demand for natural gas, especially for use in electricity generation, is expected to grow strongly. In the face of increasing fuel demands, the region will be challenged to provide new supplies and to manage existing supplies carefully.

Although the distillate oil volumes that might be appropriate or available for switching or conversion are small, these options may be useful in particular circumstances. In general, however, it will take a broad range of policies to avoid reoccurrences of the problems experienced in the 1999-2000 winter. The policies, starting with the programs and policies that helped in winter 2000, would:

- Provide immediate information and assistance

- Help with information, planning, and emergency supplies in the near term

- Add to the diversity and reliability of energy supplies for the future.

At the same time, many of the most important decisions affecting energy supply and consumption are the responsibilities of individuals, businesses, and local and State authorities. Individuals and businesses should be aware of their options to reduce vulnerability through inventory practices, purchase plans, emergency assistance, energy efficiency, and energy alternatives. State and local authorities, including State public utility commissions, State and local zoning and siting authorities, government purchasing agencies, building code agencies, and State-operated assistance programs, also have major responsibilities in several areas. Together, the impacts of Federal, State, and local government actions can increase consumer preparedness and the choices available to end users to reduce their risks.

\section{Policies for Immediate Assistance}

In an energy emergency, the Federal Government must be prepared to identify the sources of the problem, supply timely public information, and provide appropriate immediate assistance. The record from this last winter was good but could be better.

During January and February 2000, the Federal Government took a number of actions to resolve immediate supply problems in the Northeast: waiving hours-ofservice regulations for distillate delivery drivers in specific areas of the Northeast; working with States on a case-by-case basis to explore Clean Air Act waivers to increase fuel oil availability; and encouraging restoration of service to cut-off interruptible natural gas customers in the industrial sector. The Secretary of Energy urged refiners to defer routine maintenance briefly, within bounds of safety, to ensure that heating oil production was maximized. The Secretary of Energy and the Secretary of Transportation created a DOE/U.S. Coast Guard Task Force for Product Movement to take actions in ice-bound ports and rivers to avoid shipping and loading delays for heating oil.

During the same period, the Administration released $\$ 295$ million to the Low Income Home Energy Assistance Program (LIHEAP), which provides block grants from the Department of Health and Human Services to help low-income clients pay fuel bills. The Small Business Administration made loans available to heating oil distributors who were having cash flow problems, to ensure that they could continue to make deliveries. The Department of Energy also increased the frequency and timeliness of information about fuel supply and pricing and established a toll-free heating oil emergency hotline for public information.

Secretary Richardson held a series of meetings with State and local leaders, consumer groups, industry representatives, and interested citizens in Massachusetts, Maine, and New Jersey to better understand the causes and effects of the heating oil price rise. The meetings helped in understanding this winter's events but also identified areas for further investigation to make the Northeast winter fuels markets more resilient. In addition, the following action was instituted.

\section{- Create Office of Energy Emergencies to improve communication}

The meetings and behind-the-scenes work by Federal and State agencies and industry leaders resulted in a decision by the Department of Energy to reestablish an Energy Emergency Office at the Department. Establishment of the Office was announced on May 26, 2000, as part of a simulation exercise on electricity reliability. The small permanent office and its affiliates throughout the Department will provide regular workshops and exercises with State energy officials and industry partners to enhance communication and readiness for emergencies. One of the early objectives for the Office will be to develop a fuller understanding of authorities available for immediate action with other Federal, State, and local agencies. This knowledge would enable more immediate and coordinated response when energy crises occur, including heating oil/gasoline supply problems, power outages, and pipeline emergencies.

\section{Actions To Help with Near-Term Problems}

For the next few years, the majority of Northeast energy consumers-both businesses and individuals-will be using the energy capital and infrastructure now in place. 
Each will need to make sound decisions about holding inventory and using existing energy purchase plans, and they should be provided the best available information about oil markets and winter forecasts. For some there will be an opportunity to improve energy efficiency by weatherizing homes and businesses, and some conversions to new energy sources will occur. However, the unusual circumstances of this winter could occur again. In that case, immediate assistance can be provided by the Federal Government, beginning with energy assistance for low-income households. For the slightly longer term, the President has called for the early development of an environmentally sound Home Heating Oil Reserve in the Northeast as part of the resources available in the event of a serious problem. These and other options for near-term policy actions are summarized below:

\section{- Highlight seasonal information and forecasts for the Northeast energy market}

The Energy Information Administration (EIA) collects monthly and weekly information about distillate fuel oil supply in the Northeast. Data are collected from refineries in Pennsylvania and New Jersey, bulk terminals, and area pipelines. Although data on inventories held by smaller distributors and end users are not included in inventory reports, products supplied from the larger facilities indicate general demand in the region. Information about regional natural gas demand and storage is also available from EIA. In the coming fall, EIA and the National Association of State Energy Offices will highlight the winter fuels outlook for the Northeast in a fall conference.

\section{- Encourage planning and preparation by all market participants}

The Northeast can be a difficult market in which to balance supply and demand of energy services. The area is subject to sharp surges in weather-related demand and has almost no indigenous fossil energy sources with which to increase short-term energy supply. The region relies on energy shipped from distant producers and withdrawals from inventories. Consequently, it is critical for energy suppliers and consumers to be prepared for surges in demand. Preparation includes financial planning and assuring the availability of necessary goods and services. Heating oil suppliers and gas utilities should inform their customers about different forms of purchasing plans. State and Federal Government agencies should provide information about energy markets and assistance programs. DOE will work with utilities and State energy offices to evaluate the primary sources of peak demand for energy and assist their customers in reducing that demand so as to ease constraints on energy markets during periods of high demand. A separate DOE study will identify actions that might be taken by gas customers with the option to switch fuels.
- Request continued funding for the Low Income Home Energy Assistance Program and expanded funding for the Weatherization Assistance Program

LIHEAP helps protect the health of low-income families by providing assistance in meeting heating and cooling costs to approximately 4 million U.S. households each year. Those households receiving assistance include some of the most vulnerable populations: 35 percent include an elderly member; 28 percent include a person with a disability; and 48 percent include a child under age 18. Congress has provided an advance appropriation of $\$ 1.1$ billion for fiscal year 2001 and $\$ 300$ million in contingency funding to meet unexpected needs that may result from unusually high or low temperatures or natural disasters. The Administration has requested an advance appropriation of $\$ 1.1$ billion in fiscal year 2002, as well as continued funding of contingent emergency funds in the amount of $\$ 300$ million. A supplemental funding bill for contingency money to be released in coming years has passed in Congress, but the base funding remains to be addressed.

DOE's Weatherization Assistance Program helps lowincome households make their homes more energy efficient. These are the Americans who most need to reduce monthly energy costs. The program has already weatherized almost 5 million homes. The goal for fiscal year 2001 is to add more than 76,000 homes to the list. The Administration seeks $\$ 154$ million for this important program for fiscal year 2001 and an additional \$19 million for fiscal year 2000 in supplemental appropriations.

\section{- Develop a Northeast Home Heating Oil Reserve}

On March 18, 2000, President Clinton proposed the creation of an environmentally sound home heating oil reserve in the Northeast and requested that Congress pass legislation detailing the specific aspects of the reserve. The Administration believes that a reserve of 2 million barrels located in the Northeast will improve immediate access to heating oil inventories during shortages. Supplies would be available during brief periods while other shipments were in transit to the Northeast.

\section{- Study the need for area port dredging}

During winter 1999-2000, imports and large water-borne shipments to the New England area were limited to the ports of Boston, New Haven, Portland (Maine), and Portsmouth (New Hampshire). Other ports in the region receiving small quantities included Providence (Rhode Island), New London (Connecticut), and Searsport and Belfast (Maine). Some of the ports and channels in New England could be dredged and deepened to allow larger vessels to carry distillate fuel oil, and perhaps to allow larger tankers to dock and unload. Because both the ports and channels leading to and from the ports must 
be dredged, however, the projects would be expensive and could pose environmental risks. The dredging process disturbs port and channel sediments and may change the character of the water quality, thus affecting biota. The Administration recommends that the U.S. Army Corps of Engineers be provided funding for an assessment of the benefits and costs of dredging and development of area ports for fuel shipments.

\section{Policies To Add to the Diversity and Reliability of Energy Supply in the Northeast}

Over the next 20 years many significant changes are expected in Northeast energy markets as a result of independent changes in both supply and demand. In January-February 2000, both heating oil and natural gas supply were constrained as demand surged. Increased deliveries of both fuels, greater local inventories, or new fuel options would have ameliorated the problems. Demand for heating fuels can also be changed over time by conversion of distillate fuel oil customers to new energy sources or by employing greater energy efficiency in new and replacement equipment. Information and technical assistance programs can shape these demand decisions in ways that improve market performance throughout the life of the investments. The following initiatives represent an array of options to increase supply from multiple energy sources and to improve energy efficiency for a variety of consumers.

\section{- Reduce delays in Federal Government processes related to decisions on natural gas pipeline and storage capacity}

Section 7 of the Natural Gas Act requires that a person may not undertake to construct, extend, operate, or acquire jurisdictional natural gas facilities without first obtaining from the Federal Energy Regulatory Commission (FERC) a certificate of public convenience and necessity authorizing such act or operations. The Commission is responsible for adopting policies under which it determines whether to grant a certificate of public convenience and necessity for interstate natural gas pipelines and/or facilities constructed at U.S. international borders. In September 1999, in a move designed to streamline the certification process, the Commission adopted a policy statement that increased the flexibility of provisions for evaluating projects. The policy statement also confirmed that the Commission would begin its environmental review at the time an application is filed with the Commission; environmental and economic review of a proposed project will continue to proceed concurrently.

Among the most time-consuming requirements for the issuance of FERC certificates is the preparation of an environmental assessment (EA) and environmental impact statement (EIS). Typically, 6 to 9 months and 14 to 16 months are required to complete EAs and EISs, respectively. Time is required for environmental scoping, analysis, publication of the draft EIS or EA with 45-day comment period, analysis and response to comments, and publication of the final EIS. Issues related to the Endangered Species Act, the National Historic Preservation Act, and the Coastal Zone Management Act are addressed as part of the EA. These statutes mandate that the Commission not act until certain regulatory requirements, which may include consultation with the Fish and Wildlife Service, the Advisory Council of Historic Preservation, and the appropriate State Coastal Zone Management agency are met. The statutes give the agencies 90 to 135 days to act. If Federal lands are crossed, then the Bureau of Land Management (BLM), the U.S. Forest Service, or the Bureau of Reclamation, as appropriate, must be consulted. The crossing of Indian Lands requires consultation with Native American tribes and the Bureau of Indian Affairs.

In addition to the role of Federal agencies in EAs and EISs, specific permits may be necessary from other resource agencies. Construction over wetlands and streams cannot begin until the Corps of Engineers issues a permit under Section 404 of the Clean Water Act (for wetlands) or under Section 10 of the Rivers and Harbors Act (for stream crossings). If Federal land is crossed, then the agency that owns the land (e.g., BLM, Forest Service, Department of Defense, Department of the Interior, Corps of Engineers) must issue a Right-of-Way Grant under the Federal Land Policy Management Act (FLPMA). The FLPMA also requires that any pipeline 24 inches in diameter or larger receive congressional approval to cross Federal land.

Federal agency inputs to the determination process are often not provided expeditiously. The FERC is thus not provided the information and notifications of permit decisions that allow it to finish deliberations quickly. DOE recommends that the Council on Environmental Quality and the National Economic Council create an initiative involving the resource agencies and the Commission to set guidelines for completing the processes required in the Commission's deliberative process.

\section{- Support joint Federal/State studies of regional storage opportunities for natural gas}

Natural gas demand for space heating peaks seasonally. One option for meeting new gas demand is to incur construction and annual operating costs for transmission capacity that would be unused during the greater part of the year. Access to regional storage facilities would reduce winter delivery time and supplement the capacity of interstate pipelines. Almost no undeveloped natural gas storage capacity is now available in the Northeast market area. Existing storage is located primarily in 
depleted oil and gas reservoirs in Pennsylvania and New York, but the Northeast area has limited numbers of such underground formations. New forms of gas storage are needed if regional storage capacity is to be enhanced.

DOE's National Energy Technology Laboratory released this spring the final reports of four Advanced Gas Storage Projects. This research, which began in 1997, consists of feasibility studies of new or improved storage methods in areas where conventional storage is not available or does not meet the needs of end users. The studies focus on the technical and economic merits of the advanced storage concepts. The engineering and economic feasibility of constructing lined rock cavern (LRC) storage facilities for natural gas has been examined for a Boston area facility and an Atlanta facility with a total combined capacity of 7.8 billion cubic feet.

Lined rock caverns store natural gas in a manner similar to salt cavern storage but can be located in areas of the United States where salt caverns and conventional underground reservoirs are not present, including the Northeast, South Atlantic, and Northwest regions. Unlike the LNG storage option, LRCs can be cycled up to 12 times annually and can provide daily or even hourly injections and withdrawals. Because of its operational and siting flexibility, LRC storage can be located adjacent to an end user, such as a local distribution company, power plant, or large industrial facility. LRC may be the solution for natural gas to fulfill its projected role for power generation in areas of the United States without conventional storage facilities.

DOE will conduct a detailed independent technical review of the LRC concept at specific sites where LRC storage facilities are planned. This would entail sitespecific geology and mechanical (rock mechanic properties, hydrology, etc.) integrity evaluation and assessment of the LRC design work equations. DOE's LRC data and analysis would be valuable to Federal and State regulators reviewing proposed projects. DOE will provide scientific and engineering analysis to allow for risk-based regulatory decisions.

\section{- Study changes to the tax treatment for conversion/ hookup costs}

When homeowners and businesses opt to connect to utilities, including natural gas utilities, for the first time, they make a payment or contribution of property called "contributions in aid of construction" (CIAC) to the utility. Before 1986, the connection fees were treated as nontaxable income for the utility in Federal tax law and regulation. The Tax Reform Act of 1986 changed the treatment of CIAC by treating capital contributions as taxable income to the utility. In 1996, the water and wastewater industries succeeded in reinstating the nontaxable status of contributions in aid of construction for hookups to their utilities; however, the tax treatment for hookup costs for gas utilities have not changed.

Gas utilities are passing this tax obligation on to their new customers. As a result, customers at manufacturing plants, office buildings, condominiums, apartment complexes, and single-family homes pay a higher cost for connection. Utilities estimate that the cost of connecting is increased by 30 to 50 percent because of the taxable nature of the fee. A large industrial customer may pay between $\$ 500,000$ and $\$ 1,000,000$ for hookup. The Administration will study options that would make the taxable status of these contributions comparable for all types of utilities as a means of increasing fuel choices.

\section{- Facilitate increases in the Northeast's liquefied natural gas infrastructure and supplies}

Natural gas deliveries into New England come, in part, as LNG imports. This product, which is imported by Distrigas Corporation into its LNG receiving and storage facility in Boston Harbor, arrives from countries around the world. During 1999, Distrigas increased its imports by 53 billion cubic feet, from 43 billion cubic feet to 96 billion cubic feet, over its 1998 imports. Virtually all of this supply was consumed in New England.

Distrigas has plans to double its imports over the next few years. The majority of the increase will be used to fuel new electricity generating plants near Boston. The gas will be brought in under long-term contracts with Algeria and Trinidad. The company will request new or amended import authorizations to increase the amount of gas it is permitted to bring into the United States. Under the Energy Policy Act of 1992, imports of natural gas into the United States from a country with which there is in effect a free trade agreement requiring national treatment for trade in natural gas and LNG, in general, are held to be in the national interest. These requests will be granted promptly by $D O E$.

Increased LNG shipments will result in an increase in the number of tankers that the company brings into Boston Harbor. The U.S. Coast Guard is the Federal organization that regulates a tanker's movement into the harbor. Because harbor traffic is suspended while LNG tankers are in motion, the U.S. Coast Guard will probably need to conduct a proceeding to decide whether to permit the increased tanker traffic. DOE will work closely with the Department of Transportation, U.S. Coast Guard, to facilitate its review of the proposal to increase deliveries of LNG to Boston. It will be important to recognize that increasing LNG tanker traffic will reduce the times, under current Coast Guard rules and practices, when distillate deliveries can be made. 
- Develop and demonstrate alternative methods of energy backup for large natural gas users

If natural gas customers choose lower cost interruptible gas contracts, they must either stop operations when gas service is interrupted or use an alternate energy backup. For many customers with distillate boilers and turbines, the only alternative may be distillate fuel, and this alternative may be uneconomical or too difficult to manage, leaving customers without backup.

DOE will help New England consumers and utilities explore opportunities for new distributed energy systems to provide backup energy, including renewable energy, or significantly reduce peak load requirements for natural gas, electricity, and heating oil. Both heat and electric backup options can be addressed through distributed energy systems.

- Evaluate options for further reducing or converting heating oil services at selected Federal buildings in the Northeast

Federal Government buildings in many locations, after assessing service requirements for continuous operation and the costs of available energy sources, have selected heating oil as the most economic and reliable energy source. DOE will explore with Federal facilities in the Northeast whether recent changes in energy markets in the region or new energy technologies have resulted in additional life-cycle cost-effective opportunities to reduce oil use. This review will be carried out pursuant to Executive Order 13123, Greening the Government Through Efficient Energy Management, which supports energy-efficient technologies, switching to renewable energy sources, using natural gas, and eliminating unnecessary fuel use.

\section{- Support consumer education and building improvement programs}

As new residential and commercial buildings are built and, in some cases, as existing capacity is renovated, there are many opportunities to choose strategies and features that can reduce both peak and off-peak energy demand. DOE will work with builders and designers to help make such energy-saving strategies and features widely available in the Northeast. Recent design and technology developments facilitated by DOE-industry partnerships have created current opportunities for 30to 50-percent savings in space heating and cooling in homes and commercial buildings (e.g., schools and offices). Savings can be achieved in new construction with little or no additional up-front construction costs. Nearly every new home and office in New England uses natural gas, oil, or electricity for space heating. Reducing that heating load by 30 to 50 percent (for efficient homes, often more than 50 percent of peak energy use is saved) can reduce much of the expected demand increase for energy resources in the Northeast. DOE will work with energy service providers in the Northeast to make these services as widely available as possible.

\section{National Context}

The longer term goals of energy security, economic growth, and environmental quality make increased diversity and reliability of domestic energy supply and improved energy efficiency important for all U.S. regions. The prospects for increasing demand and supply in the Northeast are part of a larger national interest in expanding energy supply and the associated infrastructure to meet growing national demand.

The Clinton Administration has supported scientific and engineering studies needed to develop clean, competitive energy supplies and reliable, efficient technologies for energy distribution and end use. Beyond the contributions of science and engineering, however, a number of public actions are needed to enhance energy supply and delivery. The Administration has announced its support for changes in the tax code to support expensing of geological and geophysical costs and to delay rental payments in order to lower the costs of oil and gas development. However, a number of difficult public policy issues remain for resource development, notably, for developing natural gas supplies and delivering the product to end users. An initiative to help natural gas fulfill its potential as a clean, reliable domestic fuel would be important for all regions of the United States.

\section{- Review Interagency Work Group on Natural Gas}

The National Petroleum Council urged development of a national strategy for natural gas supply in its report to Secretary Richardson this year. The study has been well received by many stakeholders concerned about energy, environmental, and economic issues. The study recommended that an Interagency Work Group on Natural Gas be established within the National Economic Council to create a balanced, long-term approach for responsibly developing the Nation's natural gas resource base; driving research and technology development for resource development, transmission, and distribution; and streamlining and updating Federal Government processes that affect gas development and transmission. DOE and the National Economic Council are seriously reviewing a process to implement this recommendation.

\section{- Resume annual energy meetings between the United States and Canada}

New England currently relies on natural gas imports from Canada for a significant portion of its annual consumption. To improve understanding about natural gas market, regulatory, and trade issues, the Administration proposes that DOE and its Canadian counterparts, the National Energy Board of Canada and the Department 
of Natural Resources Canada, should resume regular annual meetings. Before the passage of the North American Free Trade Agreement in 1992, annual meetings between these parties helped to identify the status of pending Canadian projects involving gas trade and to identify differences on prospective gas initiatives. Similar consultations would be useful in understanding the prospects for growth in gas supply and demand for the Northeast.

The Administration has also been active in developing renewable energy sources and promoting their use. Executive Order 13134 on Bio-based Products and Bioenergy, signed by the President on August 12, 1999, is designed to coordinate Federal efforts to accelerate the development of 21st century bio-based industries that use trees, crops, and agricultural and forestry wastes to make fuels, chemicals, and electricity. In a separate Executive Memorandum, the President set a goal of tripling U.S. use of bio-based products and bioenergy by 2010. Forestry biomass application opportunities in the Northeast have been pilot-tested, and the forest products industry in New England could be a considerable source of fuel or power from its organic waste. Liquid bioenergy fuels have the potential to reduce reliance on various distillate products.

The President has also proposed tax credits to promote innovative and sustainable sources of energy-including tax credits for solar energy systems, wind power, electricity produced from biomass, and methane from landfills. The Administration's fiscal year 2001 budget requests $\$ 410$ million for DOE efforts to develop domestic sources of renewable energy, including wind, photovoltaics, and geothermal energy.

While adding to national and Northeast energy supply is important, it is equally important to use all resources as efficiently as possible. Ongoing government and industry activities in energy efficiency cut across all sectors and fuel sources. In June 1999, the President signed Executive Order 13123 on Greening the Government Through Efficient Energy Management, directing the Federal Government to be a leader in energy efficiency. As the Nation's largest energy consumer, any significant improvements in Federal energy management will save taxpayer dollars, reduce air pollution, conserve water, and cut greenhouse gas emissions. Another Federal role has been to help consumers overcome initial obstacles to using new fuels. Programs like Clean Cities are important in creating a critical volume of demand for new fuels.
In addition to efficiency at end-use sites, the growing ability to produce electricity, heat, and other energy services in homes, factories, and office buildings where the energy is used provides new flexibilities for energy markets and increased opportunities for efficiency improvements. Traditional cogeneration of electricity and steam heat is being enhanced with advanced turbines and engines. Recent advances in solar cell technologies and applications (such as direct current lighting) have made these resources more attractive as well. In addition to currently available technologies, distributed energy resources (DER) are likely to include fuel cells (for homes, cars, or factories), microturbines, and a host of integrated power, heating, and cooling technologies.

\section{Conclusion}

The Northeast is a unique energy market, relying on imports and supplies from other U.S. regions for the majority of its energy supply. The region's demand for natural gas is expected to grow significantly in the next 5 to 20 years, especially for electricity generation. Demand for heating oil is expected to remain significant over the period but not to grow relative to present levels. Opportunities for switching and conversion from heating oil by large industrial and utility customers are limited in the near term by current investments in powergenerating equipment and by the already large market share for natural gas.

The region is subject to sharp surges in heating fuel demand. Preparing for surges when they occur, while acting to reduce their frequency and severity in the future, suggests a mix of policy initiatives. In the near term the Federal Government will take a more active role in improving communication and information about supply, market options, and assistance programs, while establishing a Northeast Home Heating Oil Reserve for emergency use. To add to the diversity and depth of energy supply in the Northeast, the Federal Government will emphasize reducing delays in decisions on natural gas pipeline and storage capacity, developing new storage options, reducing obstacles to changing energy choices, and improving energy efficiency. The recommendations for the Northeast are consistent with the Administration's initiatives for longer term goals of energy security, economic growth, and environmental quality for all regions of the United States. 
(1) 
Appendix A

Request for Analysis 



\section{The Secretary of Energy}

Washington, DC 20585

March 21, 2000

\section{MEMORANDUM FOR ADMINISTRATOR, ENERGY INFORMATION ADMINISTRATION DIRECTOR, OFFICE OF POLICY \\ FROM: BILL RICHARDSON

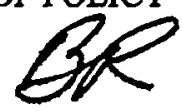

SUBJECT: $\quad$ Requests 60-day Study on Home Heating Oil and Diesel Fuel Price Spikes in the Northeast

On February 16, 2000, President Clinton tasked the Department of Energy (DOE) to undertake a study of one facet of the recent home heating oil and diesel fuel price spikes in the Northeast. His charge to us was stated as:

"I've asked Secretary Richardson to conduct a 60-day study on converting factories and major users from oil to other fuels, which will help to free up future oil supplies for use in heating homes."

I am aware that work on this study is well underway; however, this is to formally record my request that you undertake jointly a study that covers the following issues:

- A short description of the causes of the Northeast fuel oil price spikes this winter;

- The role of industrial and other large users of fuel oil in the Northeast market;

- The existing and expected near-term patterns, through 2005 , of fuel use by business, commercial, and residential consumers;

- Alternatives for greater fuel diversity or reduced distillate fuel oil use by these large users; and

- Obstacles to and incentives for conversion or reduced peak demand by distillate fuel oil users. 
The Office of Policy will have lead responsibility for the following issue:

- Federal policies that could promote conversion by various classes of users and greater energy diversity in the region (either on an annual basis or during critical demand periods). These should include policies focused on:

(1) adding to gas supply in the region,

(2) removing disincentives for provision of natural gas, and

(3) supporting changes in electricity generation practices.

The study should be completed by April 14,2000, so that we can meet the 60 day deadline for delivery to the President. At this time, the Department of Energy will send copies of the report to stakeholders such as elected officials, trade groups, and consumer organizations in the Northeast. Because of the tight deadlines, I urge you to reach out to the Federal Energy Regulatory Commission and DOE program offices, including the Office of Fossil Energy and the Office of Energy Efficiency and Renewable Energy, for their expertise.

cc: Bob Gee

Dan Reicher

James Hoecker 
Appendix B

Historical Data on Fuel Consumption and Prices for the Residential Sector in the Northeast Region 


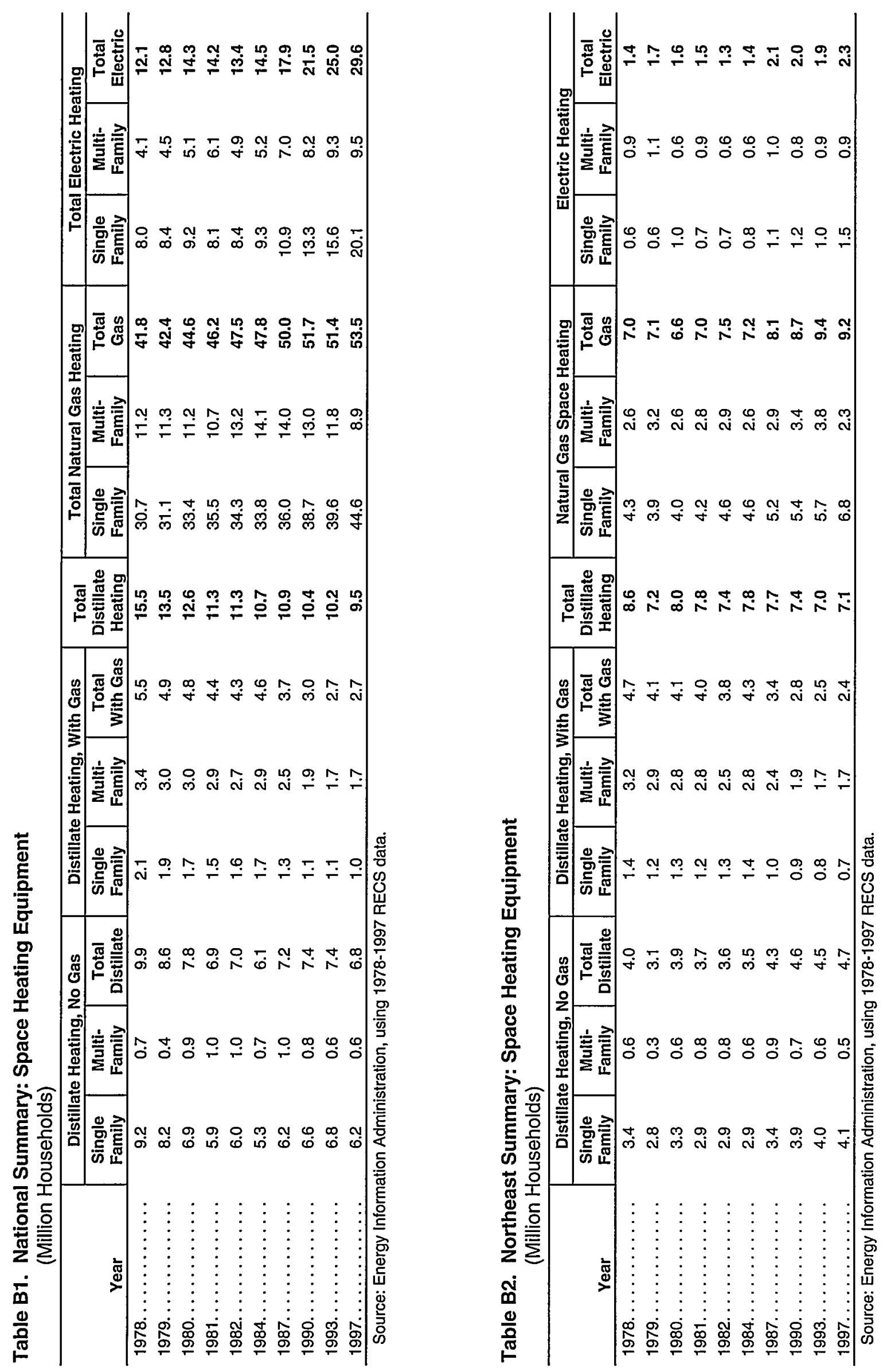
Table B3. New England Summary: Space Heating Equipment (Million Households)

\begin{tabular}{|c|c|c|c|c|c|c|c|c|c|c|c|c|c|}
\hline \multirow[b]{2}{*}{ Year } & \multicolumn{3}{|c|}{ Distillate Heating, No Gas } & \multicolumn{3}{|c|}{ Distillate Heating, With Gas } & \multirow{2}{*}{$\begin{array}{c}\text { Total } \\
\text { Distillate } \\
\text { Heating }\end{array}$} & \multicolumn{3}{|c|}{ Total Natural Gas Heating } & \multicolumn{3}{|c|}{ Total Electric Heating } \\
\hline & $\begin{array}{l}\text { Single } \\
\text { Family }\end{array}$ & $\begin{array}{l}\text { Multi- } \\
\text { Family }\end{array}$ & $\begin{array}{c}\text { Total } \\
\text { Distillate }\end{array}$ & $\begin{array}{l}\text { Single } \\
\text { Family }\end{array}$ & $\begin{array}{l}\text { Multi- } \\
\text { Family }\end{array}$ & $\begin{array}{c}\text { Total } \\
\text { With Gas }\end{array}$ & & $\begin{array}{l}\text { Single } \\
\text { Family }\end{array}$ & $\begin{array}{l}\text { Multi- } \\
\text { Family }\end{array}$ & $\begin{array}{c}\text { Total } \\
\text { Gas }\end{array}$ & $\begin{array}{l}\text { Single } \\
\text { Family }\end{array}$ & $\begin{array}{l}\text { Multi- } \\
\text { Family }\end{array}$ & $\begin{array}{c}\text { Total } \\
\text { Electric }\end{array}$ \\
\hline 1980. & 1.2 & 0.3 & 1.5 & 0.2 & 0.5 & 0.7 & 2.2 & 0.3 & 0.8 & 1.1 & 0.2 & 0.2 & 0.3 \\
\hline $1981 \ldots \ldots \ldots \ldots$ & 1.0 & 0.4 & 1.4 & 0.2 & 0.5 & 0.7 & 2.1 & 0.6 & 0.6 & 1.2 & 0.1 & 0.3 & 0.4 \\
\hline $1982 \ldots$ & 1.0 & 0.3 & 1.3 & 0.4 & 0.4 & 0.8 & 2.1 & 0.5 & 0.7 & 1.2 & 0.0 & 0.3 & 0.3 \\
\hline $1984 \ldots \ldots \ldots \ldots$ & 0.9 & 0.3 & 1.2 & 0.4 & 0.4 & 0.8 & 2.0 & 0.6 & 0.6 & 1.2 & 0.1 & 0.2 & 0.3 \\
\hline $1987 \ldots \ldots \ldots \ldots \ldots$ & 1.4 & 0.4 & 1.8 & 0.2 & 0.3 & 0.5 & 2.3 & 0.5 & 0.7 & 1.2 & 0.1 & 0.3 & 0.4 \\
\hline $1990 \ldots \ldots \ldots \ldots$ & 1.4 & 0.3 & 1.7 & 0.2 & 0.3 & 0.5 & 2.2 & 0.5 & 0.8 & 1.3 & 0.2 & 0.4 & 0.6 \\
\hline $1993 . \ldots \ldots \ldots \ldots$ & 1.8 & 0.3 & 2.0 & 0.2 & 0.3 & 0.5 & 2.6 & 0.7 & 0.9 & 1.6 & 0.2 & 0.3 & 0.5 \\
\hline $1997 \ldots \ldots \ldots \ldots \ldots$ & 2.0 & 0.3 & 2.3 & 0.3 & 0.1 & 0.4 & 2.7 & 0.8 & 0.6 & 1.5 & 0.4 & 0.3 & 0.6 \\
\hline
\end{tabular}

Source: Energy Information Administration, using 1978-1997 RECS data.

Table B4. Mid-Atlantic Summary: Space Heating Equipment

(Million Households)

\begin{tabular}{|c|c|c|c|c|c|c|c|c|c|c|c|c|c|}
\hline \multirow[b]{2}{*}{ Year } & \multicolumn{3}{|c|}{ Distillate Heating, No Gas } & \multicolumn{3}{|c|}{ Distillate Heating, With Gas } & \multirow{2}{*}{$\begin{array}{c}\text { Total } \\
\text { Distillate } \\
\text { Heating }\end{array}$} & \multicolumn{3}{|c|}{ Total Natural Gas Heating } & \multicolumn{3}{|c|}{ Total Electric Heating } \\
\hline & $\begin{array}{l}\text { Single } \\
\text { Family }\end{array}$ & $\begin{array}{l}\text { Multi- } \\
\text { Family }\end{array}$ & $\begin{array}{c}\text { Total } \\
\text { Distillate }\end{array}$ & $\begin{array}{l}\text { Single } \\
\text { Family }\end{array}$ & $\begin{array}{l}\text { Multi- } \\
\text { Family }\end{array}$ & $\begin{array}{c}\text { Total } \\
\text { With Gas }\end{array}$ & & $\begin{array}{l}\text { Single } \\
\text { Family }\end{array}$ & $\begin{array}{l}\text { Multi- } \\
\text { Family }\end{array}$ & $\begin{array}{l}\text { Total } \\
\text { Gas }\end{array}$ & $\begin{array}{l}\text { Single } \\
\text { Family }\end{array}$ & $\begin{array}{l}\text { Multi- } \\
\text { Family }\end{array}$ & $\begin{array}{c}\text { Total } \\
\text { Electric }\end{array}$ \\
\hline 1980. & 2.1 & 0.3 & 2.4 & 1.1 & 2.3 & 3.4 & 5.8 & 3.7 & 1.8 & 5.5 & 0.8 & 0.4 & 1.3 \\
\hline $1981 \ldots \ldots \ldots \ldots$ & 2.0 & 0.4 & 2.4 & 1.0 & 2.3 & 3.3 & 5.7 & 3.6 & 2.2 & 5.9 & 0.6 & 0.6 & 1.1 \\
\hline 1982. . & 1.9 & 0.4 & 2.3 & 0.9 & 2.1 & 3.0 & 5.3 & 4.1 & 2.2 & 6.3 & 0.7 & 0.3 & 1.0 \\
\hline $1984 . \ldots$ & 2.0 & 0.3 & 2.3 & 1.1 & 2.4 & 3.5 & 5.8 & 4.0 & 2.1 & 6.0 & 0.7 & 0.3 & 1.0 \\
\hline 1987. & 2.0 & 0.4 & 2.4 & 0.8 & 2.1 & 2.9 & 5.4 & 4.7 & 2.2 & 6.9 & 1.0 & 0.7 & 1.7 \\
\hline $1990 \ldots \ldots \ldots \ldots$ & 2.5 & 0.4 & 2.9 & 0.7 & 1.5 & 2.3 & 5.2 & 4.9 & 2.5 & 7.4 & 1.0 & 0.4 & 1.4 \\
\hline $1993 \ldots \ldots \ldots \ldots \ldots$ & 2.2 & 0.3 & 2.5 & 0.6 & 1.4 & 1.9 & 4.5 & 5.0 & 2.9 & 7.9 & 0.8 & 0.6 & 1.4 \\
\hline $1997 \ldots \ldots \ldots \ldots \ldots$ & 2.2 & 0.2 & 2.4 & 0.4 & 1.5 & 2.0 & 4.4 & 6.0 & 1.7 & 7.7 & 1.1 & 0.6 & 1.7 \\
\hline
\end{tabular}

Source: Energy Information Administration, using 1978-1997 RECS data. 
Table B5. Midwest Summary: Space Heating Equipment

(Million Households)

\begin{tabular}{|c|c|c|c|c|c|c|c|c|c|c|c|c|c|}
\hline \multirow[b]{2}{*}{ Year } & \multicolumn{3}{|c|}{ Distillate Heating, No Gas } & \multicolumn{3}{|c|}{ Distillate Heating, With Gas } & \multirow{2}{*}{$\begin{array}{c}\text { Total } \\
\text { Distillate } \\
\text { Heating }\end{array}$} & \multicolumn{3}{|c|}{ Total Natural Gas Heating } & \multicolumn{3}{|c|}{ Total Electric Heating } \\
\hline & $\begin{array}{l}\text { Single } \\
\text { Family } \\
\end{array}$ & $\begin{array}{l}\text { Multi- } \\
\text { Family }\end{array}$ & $\begin{array}{c}\text { Total } \\
\text { Distillate }\end{array}$ & $\begin{array}{l}\text { Single } \\
\text { Family } \\
\end{array}$ & $\begin{array}{l}\text { Multi- } \\
\text { Family }\end{array}$ & $\begin{array}{c}\text { Total } \\
\text { With Gas }\end{array}$ & & $\begin{array}{l}\text { Single } \\
\text { Family }\end{array}$ & $\begin{array}{l}\text { Multim } \\
\text { Family }\end{array}$ & $\begin{array}{c}\text { Total } \\
\text { Gas }\end{array}$ & $\begin{array}{l}\text { Single } \\
\text { Family } \\
\end{array}$ & $\begin{array}{l}\text { Multi- } \\
\text { Family }\end{array}$ & $\begin{array}{c}\text { Total } \\
\text { Electric }\end{array}$ \\
\hline 1980 & 1.3 & 0.1 & 1.4 & 0.1 & 0.0 & 0.1 & 1.5 & 11.0 & 4.0 & 15.0 & 1.2 & 0.9 & 2.1 \\
\hline 1981 & 1.4 & 0.1 & 1.5 & 0.1 & 0.0 & 0.1 & 1.6 & 11.9 & 3.5 & 15.4 & 0.6 & 1.0 & 1.6 \\
\hline 1982 & 1.2 & 0.2 & 1.4 & 0.1 & 0.1 & 0.2 & 1.5 & 10.9 & 4.6 & 15.5 & 1.3 & 0.8 & 2.1 \\
\hline 1984 & 1.0 & 0.1 & 1.0 & 0.1 & 0.0 & 0.1 & 1.1 & 11.0 & 5.4 & 16.4 & 1.0 & 0.3 & 1.3 \\
\hline 1987 & 1.3 & 0.0 & 1.3 & 0.1 & 0.0 & 0.1 & 1.5 & 11.5 & 5.0 & 16.5 & 1.1 & 0.3 & 1.5 \\
\hline 1990 & 1.1 & 0.0 & 1.1 & 0.1 & 0.0 & 0.1 & 1.2 & 12.4 & 4.1 & 16.5 & 1.4 & 1.3 & 2.6 \\
\hline 1993 & 1.1 & 0.0 & 1.2 & 0.1 & 0.0 & 0.1 & 1.3 & 12.8 & 4.1 & 16.9 & 1.8 & 1.1 & 2.9 \\
\hline 1997 & 1.0 & 0.0 & 1.0 & 0.0 & 0.0 & 0.0 & 1.0 & 14.9 & 3.0 & 17.9 & 1.5 & 1.2 & 2.7 \\
\hline
\end{tabular}

Source: Energy Information Administration, using 1978-1997 RECS data.

Table B6. Regional Fuel Consumption for Residential Space Heating (Quadrillion Btu)

\begin{tabular}{|c|c|c|c|c|c|c|c|c|c|c|c|c|c|c|c|}
\hline \multirow[t]{2}{*}{ Year } & \multicolumn{5}{|c|}{ Oil Heating } & \multicolumn{5}{|c|}{ Gas Heating } & \multicolumn{5}{|c|}{ Electric Heating } \\
\hline & $\begin{array}{c}\text { New } \\
\text { England }\end{array}$ & $\begin{array}{c}\begin{array}{c}\text { Mid- } \\
\text { Atlantic }\end{array} \\
\end{array}$ & Northeast & Midwest & USA & $\begin{array}{c}\text { New } \\
\text { England }\end{array}$ & $\begin{array}{c}\text { Mid- } \\
\text { Atlantic } \\
\end{array}$ & Northeast & Midwest & USA & $\begin{array}{c}\text { New } \\
\text { England }\end{array}$ & $\begin{array}{c}\text { Mid- } \\
\text { Atlantic } \\
\end{array}$ & Northeast & Midwest & USA \\
\hline $1980 \ldots$ & 0.254 & 0.607 & 0.861 & 0.137 & 1.233 & 0.096 & 0.533 & 0.629 & 1.486 & 3.302 & 0.008 & 0.034 & 0.042 & 0.061 & 0.276 \\
\hline $1981 \ldots$ & 0.204 & 0.532 & 0.736 & 0.155 & 1.032 & 0.117 & 0.611 & 0.728 & 1.746 & 3.782 & 0.013 & 0.043 & 0.056 & 0.052 & 0.299 \\
\hline $1982 \ldots$ & 0.202 & 0.474 & 0.677 & 0.137 & 0.964 & 0.107 & 0.559 & 0.666 & 1.327 & 3.277 & 0.008 & 0.025 & 0.033 & 0.069 & 0.266 \\
\hline 1984. . . & 0.215 & 0.512 & 0.726 & 0.105 & 0.948 & 0.110 & 0.528 & 0.638 & 1.563 & 3.472 & 0.009 & 0.029 & 0.038 & 0.047 & 0.263 \\
\hline $1987 \ldots$ & 0.205 & 0.461 & 0.666 & 0.120 & 0.912 & 0.099 & 0.625 & 0.725 & 1.399 & 3.345 & 0.010 & 0.038 & 0.047 & 0.045 & 0.283 \\
\hline $1990 .$. & 0.213 & 0.415 & 0.629 & 0.109 & 0.828 & 0.098 & 0.614 & 0.712 & 1.421 & 3.339 & 0.011 & 0.030 & 0.041 & 0.058 & 0.303 \\
\hline 1993. . . & 0.248 & 0.380 & 0.629 & 0.123 & 0.885 & 0.125 & 0.646 & 0.771 & 1.558 & 3.645 & 0.010 & 0.031 & 0.040 & 0.074 & 0.407 \\
\hline $1997 . .$. & 0.271 & 0.372 & 0.642 & 0.100 & 0.834 & 0.121 & 0.618 & 0.738 & 1.650 & 3.579 & 0.012 & 0.031 & 0.042 & 0.054 & 0.380 \\
\hline
\end{tabular}

Source: Energy Information Administration, using 1978-1997 RECS data. 
Table B7. Regional Fuel Expenditures for Residential Space Heating (1998 Dollars per Household)

\begin{tabular}{|c|c|c|c|c|c|c|c|c|c|c|c|c|c|c|c|}
\hline \multirow[b]{2}{*}{ Year } & \multicolumn{5}{|c|}{ Oil Space Heating } & \multicolumn{5}{|c|}{ Natural Gas Space Heating } & \multicolumn{5}{|c|}{ Electric Space Heating } \\
\hline & $\begin{array}{c}\text { New } \\
\text { England }\end{array}$ & $\begin{array}{c}\text { Mid- } \\
\text { Atlantic }\end{array}$ & Northeast & Midwest & USA & $\begin{array}{c}\text { New } \\
\text { England }\end{array}$ & $\begin{array}{c}\text { Mid- } \\
\text { Atlantic }\end{array}$ & Northeast & Midwest & USA & $\begin{array}{c}\text { New } \\
\text { England }\end{array}$ & $\begin{array}{c}\text { Mid- } \\
\text { Atlantic }\end{array}$ & Northeast & Midwest & USA \\
\hline $1980 \ldots$ & 1640 & 1511 & 1547 & 1271 & 1414 & 890 & 803 & 817 & 632 & 510 & 924 & 851 & 866 & 708 & 466 \\
\hline $1981 \ldots$ & 1439 & 1369 & 1388 & 1354 & 1326 & 1118 & 895 & 933 & 771 & 602 & 1257 & 1171 & 1193 & 814 & 530 \\
\hline 1982... & 1261 & 1159 & 1187 & 1139 & 1109 & 1145 & 921 & 957 & 690 & 598 & 945 & 887 & 900 & 821 & 514 \\
\hline $1984 \ldots$ & 1178 & 942 & 1004 & 997 & 960 & 1021 & 882 & 905 & 763 & 612 & 938 & 1028 & 1006 & 898 & 481 \\
\hline $1987 \ldots$ & 696 & 652 & 665 & 632 & 645 & 729 & 735 & 734 & 549 & 471 & 730 & 700 & 706 & 782 & 408 \\
\hline $1990 \ldots$ & 887 & 756 & 796 & 822 & 743 & 666 & 663 & 663 & 502 & 422 & 577 & 676 & 645 & 524 & 339 \\
\hline 1993... & 693 & 599 & 633 & 643 & 619 & 711 & 661 & 670 & 542 & 463 & 693 & 631 & 646 & 582 & 378 \\
\hline $1997 . \ldots$ & 716 & 606 & 648 & 670 & 637 & 772 & 693 & 705 & 549 & 452 & 571 & 529 & 540 & 410 & 273 \\
\hline
\end{tabular}

Source: Energy Information Administration, using 1978-1997 RECS data.

Table B8. Regional Fuel Prices

(1998 Dollars per Million Btu)

\begin{tabular}{|c|c|c|c|c|c|c|c|c|c|c|c|c|c|c|c|}
\hline \multirow[t]{2}{*}{ Year } & \multicolumn{5}{|c|}{ Oil Space Heating } & \multicolumn{5}{|c|}{ Natural Gas Space Heating } & \multicolumn{5}{|c|}{ Electric Space Heating } \\
\hline & $\begin{array}{c}\text { New } \\
\text { England }\end{array}$ & $\begin{array}{c}\text { Mid- } \\
\text { Atlantic }\end{array}$ & Northeast & Midwest & USA & $\begin{array}{c}\text { New } \\
\text { England }\end{array}$ & $\begin{array}{c}\text { Mid- } \\
\text { Atlantic }\end{array}$ & Northeast & Midwest & USA & $\begin{array}{c}\text { New } \\
\text { England }\end{array}$ & $\begin{array}{c}\text { Mid- } \\
\text { Atlantic }\end{array}$ & Northeast & Midwest & USA \\
\hline $1980 \ldots$ & 14.5 & 14.4 & 14.4 & 14.2 & 14.4 & 10.2 & 8.3 & 8.6 & 6.4 & 6.9 & 36.6 & 31.1 & 32.2 & 24.6 & 24.1 \\
\hline $1981 \ldots$ & 14.7 & 14.6 & 14.6 & 14.3 & 14.6 & 11.3 & 8.6 & 9.0 & 6.8 & 7.4 & 37.1 & 31.4 & 32.8 & 25.1 & 25.2 \\
\hline $1982 .$. & 13.1 & 13.0 & 13.0 & 12.8 & 13.0 & 12.8 & 10.5 & 10.8 & 8.1 & 8.7 & 36.8 & 35.7 & 35.9 & 25.0 & 25.8 \\
\hline $1984 \ldots$ & 11.2 & 10.6 & 10.8 & 10.9 & 10.9 & 10.8 & 10.0 & 10.2 & 8.0 & 8.4 & 36.0 & 36.1 & 36.1 & 25.7 & 26.6 \\
\hline $1987 \ldots$ & 7.8 & 7.6 & 7.7 & 7.7 & 7.7 & 8.7 & 8.1 & 8.2 & 6.5 & 7.0 & 31.5 & 31.2 & 31.3 & 25.3 & 25.8 \\
\hline $1990 \ldots$ & 9.4 & 9.4 & 9.4 & 9.1 & 9.3 & 9.1 & 8.0 & 8.1 & 5.8 & 6.5 & 33.8 & 30.8 & 31.6 & 23.7 & 24.1 \\
\hline $1993 .$. & 7.1 & 7.0 & 7.1 & 6.8 & 7.1 & 9.0 & 8.0 & 8.2 & 5.9 & 6.5 & 34.1 & 29.6 & 30.6 & 22.7 & 23.2 \\
\hline $1997 \ldots$ & 7.2 & 7.1 & 7.1 & 6.9 & 7.2 & 9.3 & 8.6 & 8.7 & 6.0 & 6.7 & 31.8 & 29.3 & 30.0 & 20.2 & 21.3 \\
\hline
\end{tabular}

Source: Energy Information Administration, using 1978-1997 RECS data. 
Table B9. Regional Fuel Consumption for Residential Space Heating If All Households With Oil Heat and Gas Service Switched to Gas Heat (Quadrillion Btu)

\begin{tabular}{|c|c|c|c|c|c|c|c|c|c|c|}
\hline \multirow[b]{2}{*}{ Year } & \multicolumn{5}{|c|}{ Oil Space Heating } & \multicolumn{5}{|c|}{ Natural Gas Space Heating } \\
\hline & New England & Mid-Atlantic & Northeast & Midwest & USA & New England & Mid-Atlantic & Northeast & Midwest & USA \\
\hline $1980 \ldots \ldots$ & 0.173 & 0.259 & 0.432 & 0.126 & 0.745 & 0.177 & 0.881 & 1.058 & 1.497 & 3.791 \\
\hline $1981 \ldots \ldots$ & 0.142 & 0.226 & 0.368 & 0.141 & 0.627 & 0.180 & 0.916 & 1.096 & 1.760 & 4.187 \\
\hline $1982 . \ldots \ldots$ & 0.122 & 0.210 & 0.332 & 0.121 & 0.579 & 0.187 & 0.823 & 1.010 & 1.342 & 3.662 \\
\hline $1984 \ldots \ldots$ & 0.126 & 0.213 & 0.339 & 0.096 & 0.533 & 0.199 & 0.826 & 1.025 & 1.572 & 3.887 \\
\hline $1987 \ldots \ldots$ & 0.161 & 0.238 & 0.398 & 0.112 & 0.620 & 0.144 & 0.849 & 0.993 & 1.407 & 3.637 \\
\hline $1990 . \ldots \ldots$ & 0.167 & 0.254 & 0.421 & 0.102 & 0.600 & 0.145 & 0.775 & 0.920 & 1.428 & 3.567 \\
\hline $1993 . . . \ldots$ & 0.196 & 0.253 & 0.449 & 0.108 & 0.678 & 0.177 & 0.774 & 0.951 & 1.573 & 3.852 \\
\hline $1997 . \ldots \ldots$ & 0.229 & 0.238 & 0.467 & 0.097 & 0.638 & 0.163 & 0.751 & 0.914 & 1.653 & 3.775 \\
\hline
\end{tabular}

Source: Energy Information Administration, using 1978-1997 RECS data.

Table B10. Regional Fuel Expenditures for Residential Space Heating If All Households With Oil Heat and Gas Service Switched to Gas Heat (1998 Dollars per Household)

\begin{tabular}{|c|c|c|c|c|c|c|c|c|c|c|}
\hline \multirow[b]{2}{*}{ Year } & \multicolumn{5}{|c|}{ Oil Space Heating } & \multicolumn{5}{|c|}{ Natural Gas Space Heating } \\
\hline & New England & Mid-Atlantic & Northeast & Midwest & USA & New England & Mid-Atlantic & Northeast & Midwest & USA \\
\hline $1980 \ldots \ldots$ & 1650 & 1561 & 1596 & 1248 & 1371 & 986 & 821 & 849 & 633 & 545 \\
\hline $1981 \ldots \ldots$ & 1538 & 1388 & 1443 & 1320 & 1309 & 1060 & 859 & 893 & 772 & 621 \\
\hline $1982 . \ldots \ldots$ & 1222 & 1173 & 1191 & 1136 & 1073 & 1204 & 922 & 972 & 691 & 629 \\
\hline $1984 \ldots \ldots$ & 1147 & 1016 & 1061 & 1007 & 965 & 1084 & 877 & 913 & 762 & 638 \\
\hline $1987 . \ldots \ldots$ & 684 & 754 & 724 & 650 & 672 & 751 & 700 & 708 & 548 & 483 \\
\hline $1990 \ldots \ldots$ & 907 & 834 & 862 & 815 & 760 & 701 & 640 & 650 & 502 & 433 \\
\hline $1993 . . . \ldots$ & 691 & 715 & 704 & 627 & 652 & 754 & 635 & 656 & 543 & 470 \\
\hline $1997 . \ldots \ldots$ & 723 & 736 & 729 & 671 & 687 & 796 & 671 & 691 & 549 & 460 \\
\hline
\end{tabular}

Source: Energy Information Administration, using 1978-1997 RECS data. 

Appendix C

Historical Distillate Price Spikes: December 1989-January 1990, January-February 1994, and January-February 2000 



\section{Appendix C}

\section{Historical Distillate Price Spikes: December 1989-January 1990, January-February 1994, and January-February 2000}

The Northeast has experienced three distillate price spikes in recent years: December 1989-January 1990, January-February 1994, and January/February 2000. In all three cases, distillate prices suddenly soared above crude oil prices, remaining volatile and elevated for several weeks. Figure $C 1$ shows the spread between distillate and crude oil prices since 1989, illustrating the magnitude of the different spikes.

In nominal terms, crude oil prices exacerbated the impact of the spike on consumers in the January 2000 case more than in 1989 or 1994. Crude oil prices were low during the January/February 1994 incident. During the peak distillate price week in 1994, the crude oil price averaged less than $\$ 15$ per barrel ( 35 cents per gallon); during the peak of the winter 1989/90 event, crude oil was $\$ 21.70$ per barrel (52 cents per gallon); and the latest event had an underlying crude oil price of $\$ 28.06$ per barrel ( 67 cents per gallon). As a result, the total distillate price peak was higher during the recent January/February 2000 event than during the two other price spikes.

Figure C1. New York Harbor No. 2 Heating Oil Spot Prices Minus West Texas Intermediate Crude Oil Spot Prices, 1989-1999 Cents per Gallon

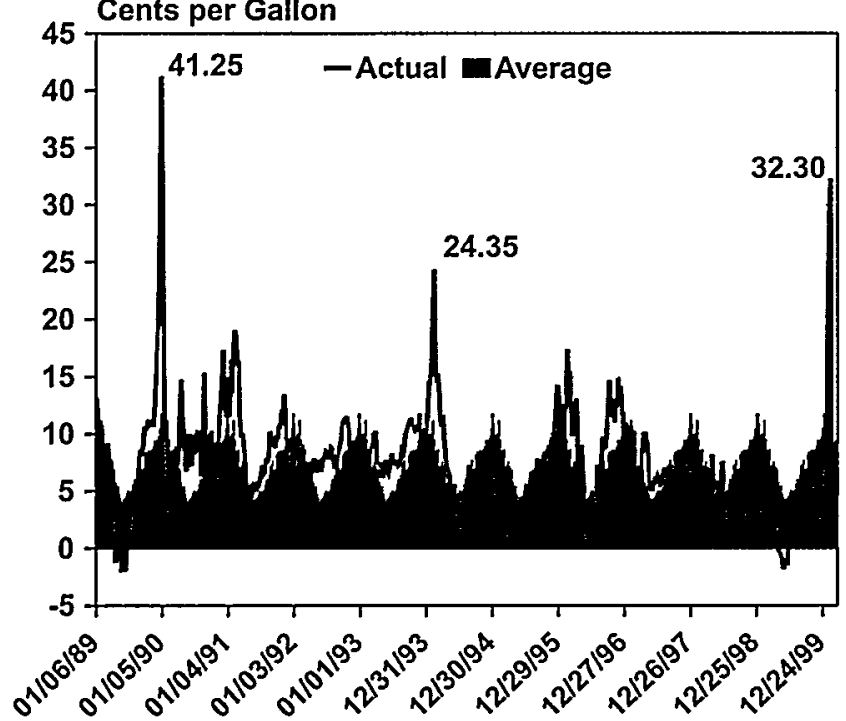

Source: DRI Platt's daily prices averaged over a week.
The three incidents had many similarities, but there were differences as well. Each involved a surge in demand during cold weather, accompanied by supply disruptions due to refinery outages and weather-related delivery problems. Stocks were rapidly drawn down to very low levels as demand exceeded the arrival of new supply, and prices spiked. However, stock availability at the start of the event and the severity of the weather were different for the three situations.

Stocks have played an important role in each of the price spikes. During a typical winter, distillate stocks are built up during the summer and fall, peaking in November ahead of the high winter demand months of January, February, and March. Most of the seasonal build occurs in the Northeast. Stocks are then used to help meet demand during the peak winter months. In addition to being a supply source themselves during the peak demand months, stocks are the nearest source of supply to the end-use markets, and they act as a supply buffer against unexpected surges in demand or loss of other supply, such as refinery outages. Thus, if demand is high and stocks are low and falling, then demand exceeds the arrival of new supply, and buyers bid prices up as their concern over supply availability increases. The increased price provides the incentive for added supply from increased refinery production and increased imports of distillate. Because the supply additions may take 2 to 3 weeks to be arranged for and delivered, stocks must cover the imbalance until the added supply arrives.

\section{Dynamics of Winter Distillate Markets: Winter 1989-1990}

The winter heating season of 1989-1990 began with an extremely low level of distillate stocks. The distillate stock build of late summer and fall was unusually small, and as December began, stock levels for the United States were more than 14 million barrels below average. ${ }^{102}$ The East Coast was only in a little better shape at 7 million barrels below average (Figure $\mathrm{C} 2$ ).

Refiners increased distillate production in November and early December, which might have provided some additional stock build had the weather cooperated. It turned unusually cold early in the season, however,

${ }^{102}$ The average winter East Coast and total U.S. distillate stock patterns are based on data for the years 1989-1999. 
averaging 36 percent colder than normal during December. In the second and third weeks of December, distillate production was at the highest levels seen at any point during the 3 years before 1989 . But on the weekend of December 23rd, cold weather that had been plaguing the U.S. mid-continent and Northeast hit the Gulf Coast. The record-breaking cold front froze water pipes and damaged valves and instruments in refineries. Many refineries were shut down or curtailed production, and some put customers on allocation. Distillate production fell by almost 400,000 barrels per day in the fourth week of December 1989. Furthermore, natural gas production was curtailed by frozen equipment, requiring more natural gas customers to switch to distillate than might otherwise have been the case.

With stocks well below normal, distillate price spreads (No. 2 heating oil minus West Texas Intermediate) at the beginning of December were 15 cents per gallon and growing. The price spiked at the end of month, and the distillate spread grew to over 41 cents by the end of December. In response to the high prices, imports increased, rising from about 200,000 barrels per day for the week ending December 8 to 616,000 barrels per day for the wreek of February 2, 1990. Imports then fell back to around 300,000 barrels per day in March. East Coast refinery production peaked at 480,000 barrels per day for the week of January 5 before drifting down to about 400,000 barrels per day at the beginning of February.

\section{Dynamics of Winter Distillate Markets: Winter 1993-1994}

The winter of 1993-1994 began with East Coast distillate stock levels above average, and they stayed about $7 \mathrm{mil}-$ lion barrels above average through the beginning of January. But during the first 5 weeks of the year, East Coast stocks fell by an astounding 31 million barrels (Figure C3). January 1994 was 15 percent colder than normal in the Northeast, and one week was 40 percent colder than normal. ${ }^{103}$ The cold weather did not extend to the Gulf Coast, and deliveries of both natural gas and petroleum from there to the Northeast were maintained, unlike during the December 1989-January 1990 event. Distillate spreads during January rose by 5 cents per gallon, to 15 cents per gallon at the end of the month. Distillate prices in New York Harbor were 9 cents per gallon higher than in Rotterdam-more than sufficient to attract imports.

During the last week of the East Coast stock decline (ending February 4, 1994), stocks stood at a level that was 12 million barrels below average, and distillate spreads peaked shortly thereafter at 28 cents per gallon (daily). The rise to peak prices from mid-January to mid-February resulted in increased supply. East Coast refinery production increased by about 50,000 barrels
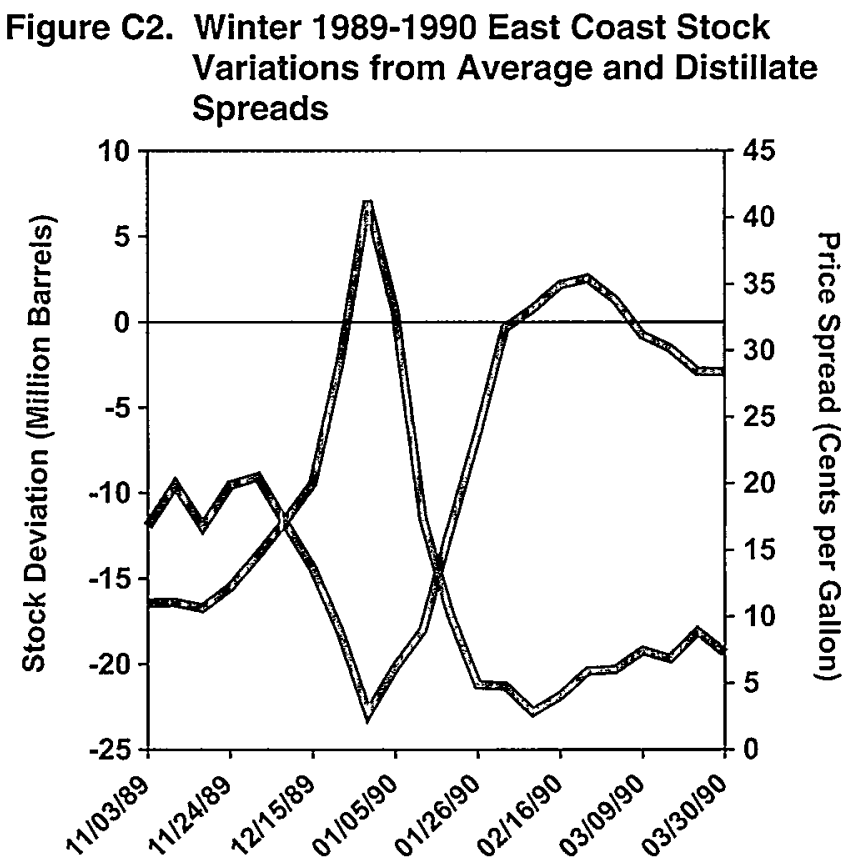

Notes: Price spread is the weekly average New York Harbor No. 2 heating oil price minus the West Texas Intermediate crude oil price. Stock deviation is the week-ending stock level minus the average week-ending level for the given week, calculated from 1989 through 1999.

Sources: Spot Prices: DRI Platt's daily prices averaged over a week. Week-Ending Distillate Stocks, January 1990 Forward: Energy Information Administration, Weekly Petroleum Status Report, DOE/EIA-0208 (various issues), Table 10. Week-Ending Distillate Stocks, November and December 1989: American Petroleum Institute.

per day over January, and imports to the East Coast increased by about 120,000 barrels per day. East Coast stocks leveled out during February, although they remained at a very low level. Because of the delivery time lag, imports did not peak until the first week in March, when they reached 450,000 barrels per day, compared with January levels of less than 200,000 barrels per day.

\section{Dynamics of Winter Distillate Markets: Winter 1999-2000}

As the heating season of 1999-2000 began, distillate stocks were about average. But from December 17, 1999, to January 14,2000 , stocks fell by 12 million barrels, ending at a level that was 10 million barrels below average (Figure C4). Distillate spreads were well below seasonal averages in December, and they strengthened only modestly in early January, remaining below average. In the week ending January 21, the weather turned sharply colder for several weeks. Demand rose, and frozen rivers and high winds interfered with product deliveries. Distillate spreads rose sharply. The average weekly

\footnotetext{
${ }^{103}$ Petroleum Industry Research Foundation, "Oil Markets During the Cold Weather: The Buck Stops Here," Memorandum Submitted to the Subcommittee on Energy and Power of the Energy and Commerce Committee, U.S. House of Representatives (February 18, 1994).
} 
Figure C3. Winter 1993-1994 East Coast Stock Variations from Average and Distillate Spreads

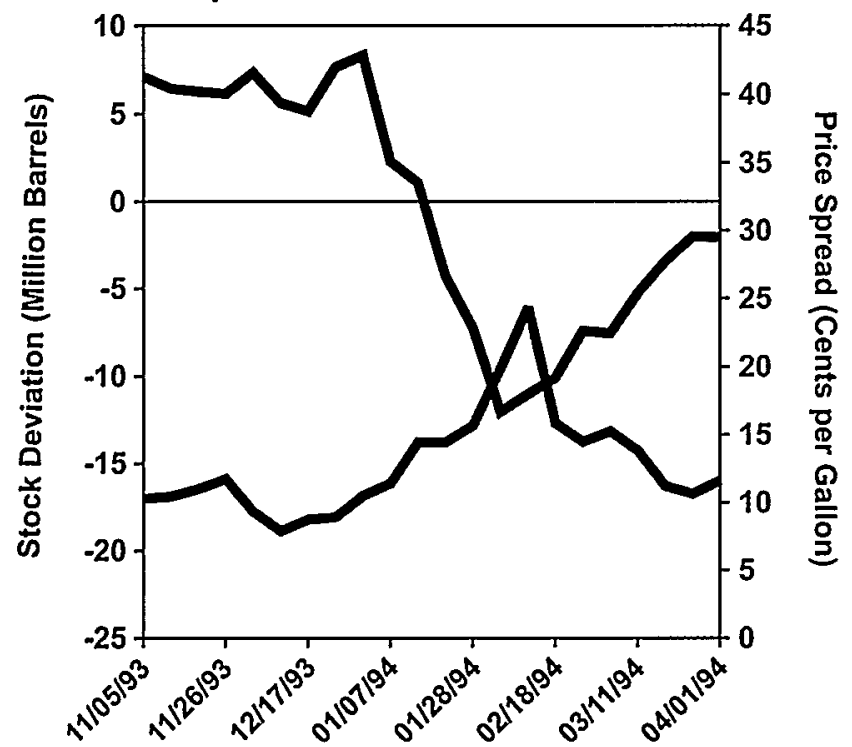

Notes: Price spread is the weekly average New York Harbor No. 2 heating oil price minus the West Texas Intermediate crude oil price. Stock deviation is the week-ending stock level minus the average week-ending level for the given week, calculated from 1989 through 1999.

Sources: Spot Prices: DRI Platt's daily prices averaged over a week. Week-Ending Distillate Stocks, January 1990 Forward: Energy Information Administration, Weekly Petroleum Status Report, DOE/EIA-0208 (various issues), Table 10. Week-Ending Distillate Stocks, November and December 1989: American Petroleum Institute.

distillate spread increased by 14 cents per gallon over the level of the previous week as the region waited for new supply to relieve the imbalance.

East Coast refinery production increased by 60,000 barrels per day during the week ending February 4 and by another 60,000 barrels per day the following week. The rise in distillate production followed the margin rise by nearly 3 weeks. Imports for the week ending February 11 were 528,000 barrels per day, compared with 105,000 barrels per day during the previous week. Very high levels of imports continued for 3 weeks, averaging 566,000 barrels per day. By February 4, East Coast stocks had fallen to 20 million barrels below average before new supply was able to stop the decline. During the rest of February, distillate stocks on the East Coast stayed flat, improving relative to the normal pattern, which declines during the first quarter of the year.

\section{Summary}

Comparing the distillate stock level for the East Coast region (PADD 1) with the average winter pattern provides a good indication of the potential for price spikes.
Figure C4. Winter 1999-2000 East Coast Stock Variations from Average and Distillate Spreads

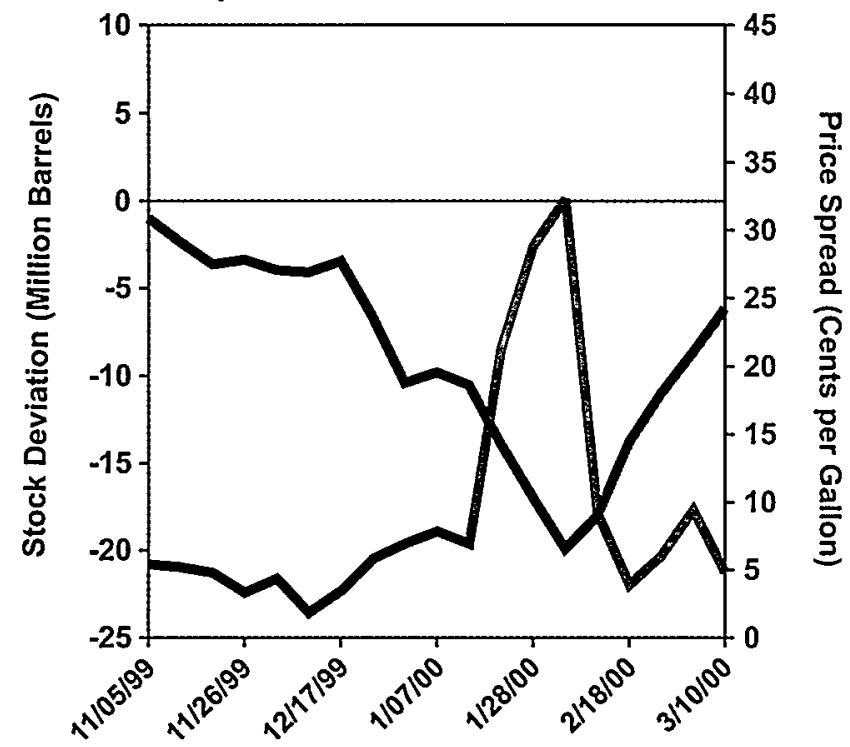

Notes: Price spread is the weekly average New York Harbor No. 2 heating oil price minus the West Texas Intermediate crude oil price. Stock deviation is the week-ending stock level minus the average week-ending level for the given week, calculated from 1989 through 1999.

Sources: Spot Prices: DRI Platt's daily prices averaged over a week. Week-Ending Distillate Stocks, January 1990 Forward: Energy Information Administration, Weekly Petroleum Status Report, DOE/EIA-0208 (various issues), Table 10. Week-Ending Distillate Stocks, November and December 1989: American Petroleum Institute.

In each of the three events discussed here, when PADD 1 stocks fell to 10 million barrels below average, a price spike followed. In the most severe incidents-1989-1990 and 1999-2000-stocks ultimately fell to 20 million barrels below average. There has been only one other winter season since 1989 when stocks fell to 10 million barrels below average, and that was in February 1996. For the week ending February 16, 1996, stocks were 10.7 million barrels below average. Weekly average distillate spreads had increased from 11 cents per gallon to 17 cents per gallon over the preceding 2 weeks. But in the following 2 weeks, demand moderated and was in balance with supply. Stocks stopped falling, and distillate spreads fell back. The imbalance was of a shorter duration.

In summary, when East Coast winter stocks levels are below normal and there is an imbalance between supply and demand that results in a rapid drawdown of stocks, price pressure mounts as inventories approach 10 million barrels below average. If the level approaches 20 million barrels below average, Northeast prices are likely to spike. The examples to date indicate that such spikes can be severe. 

Appendix D

Electricity Generation and Fuel Consumption Data, 1980-1999 
Table D1. Electricity Generation by Fuel, 1980-1999

(Megawatthours)

\begin{tabular}{|c|c|c|c|c|c|c|c|c|c|c|c|}
\hline \multicolumn{12}{|c|}{ Electric Utility Generation } \\
\hline Year & Coal & Heavy Oil ${ }^{\mathrm{a}}$ & Hydro & Light Oil ${ }^{\mathrm{a}}$ & Natural Gas & Nuclear & Other & Total & $\begin{array}{c}\% \\
\text { Heavy } \\
\text { Oil }^{\mathrm{a}}\end{array}$ & $\begin{array}{c}\% \\
\text { Light } \\
\text { Oil }^{\mathrm{a}}\end{array}$ & $\begin{array}{c}\% \\
\text { Oil } \\
\end{array}$ \\
\hline 1980. . & $1,161,562,405$ & $232,141,939$ & $276,021,192$ & $13,447,470$ & $346,239,969$ & $251,115,612$ & $5,911,109$ & $2,286,439,696$ & $10.15 \%$ & $0.59 \%$ & $10.74 \%$ \\
\hline$\ldots \ldots \ldots$ & $1,203,203,324$ & $196,019,707$ & $260,683,719$ & $10,049,895$ & $345,777,209$ & $272,673,555$ & $6,405,233$ & $2,294,812,642$ & $8.54 \%$ & $0.44 \%$ & $8.98 \%$ \\
\hline$\ldots \ldots \ldots$ & $1,192,004,270$ & $139,030,539$ & $309,213,090$ & $7,392,201$ & $305,259,814$ & $282,773,297$ & $5,538,667$ & $2,241,211,878$ & $6.20 \%$ & $0.33 \%$ & $6.53 \%$ \\
\hline$\ldots \ldots \ldots$ & $1,259,424,317$ & $135,871,495$ & $332,129,928$ & $7,972,536$ & $274,098,499$ & $293,677,148$ & $7,111,027$ & $2,310,284,950$ & $5.88 \%$ & $0.35 \%$ & $6.23 \%$ \\
\hline$\ldots \ldots \ldots$ & $1,341,680,794$ & $111,730,557$ & $321,150,440$ & $7,460,401$ & $297,393,648$ & $327,633,552$ & $9,255,230$ & $2,416,304,622$ & $4.62 \%$ & $0.31 \%$ & $4.93 \%$ \\
\hline $1985 \ldots \ldots \ldots \ldots$ & $1,402,128,153$ & $92,548,917$ & $281,149,617$ & $7,050,532$ & $291,945,995$ & $383,690,727$ & $11,327,367$ & $2,469,841,308$ & $3.75 \%$ & $0.29 \%$ & $4.03 \%$ \\
\hline $1986 \ldots \ldots \ldots \ldots$ & $1,385,831,473$ & $128,780,706$ & $290,844,314$ & $6,961,050$ & $248,508,475$ & $414,038,069$ & $12,346,127$ & $2,487,310,214$ & $5.18 \%$ & $0.28 \%$ & $5.46 \%$ \\
\hline $1987 \ldots \ldots \ldots \ldots \ldots$ & $1,463,781,290$ & $109,830,793$ & $249,695,233$ & $7,764,358$ & $272,620,840$ & $455,270,390$ & $13,163,995$ & $2,572,126,899$ & $4.27 \%$ & $0.30 \%$ & $4.57 \%$ \\
\hline$\ldots \ldots \ldots$ & $1,540,652,759$ & $138,637,645$ & $222,939,877$ & $9,222,815$ & $252,800,706$ & $526,973,056$ & $13,023,420$ & $2,704,250,278$ & $5.13 \%$ & $0.34 \%$ & $5.47 \%$ \\
\hline $1989 .$. & $1,553,661,269$ & $144,746,151$ & $265,063,302$ & $12,232,745$ & $266,598,229$ & $529,354,733$ & $12,648,386$ & $2,784,304,815$ & $5.20 \%$ & $0.44 \%$ & $5.64 \%$ \\
\hline $1990 \ldots$ & $1,559,605,707$ & $107,935,943$ & $279,925,918$ & $7,546,663$ & $264,089,401$ & $576,861,678$ & $12,185,699$ & $2,808,151,009$ & $3.84 \%$ & $0.27 \%$ & $4.11 \%$ \\
\hline 1991... & $1,551,166,838$ & $103,113,412$ & $275,519,186$ & $7,021,584$ & $264,171,598$ & $612,565,087$ & $11,465,160$ & $2,825,022,865$ & $3.65 \%$ & $0.25 \%$ & $3.90 \%$ \\
\hline$\ldots \ldots \ldots$ & $1,575,895,394$ & $81,206,269$ & $239,559,447$ & $5,777,272$ & $263,871,508$ & $618,776,263$ & $12,132,998$ & $2,797,219,151$ & $2.90 \%$ & $0.21 \%$ & $3.11 \%$ \\
\hline$\ldots \ldots \ldots$ & $1,639,151,186$ & $89,950,830$ & $265,062,757$ & $6,524,028$ & $258,915,301$ & $610,291,214$ & $12,629,450$ & $2,882,524,766$ & $3.12 \%$ & $0.23 \%$ & $3.35 \%$ \\
\hline $1994 \ldots \ldots \ldots \ldots \ldots$ & $1,635,492,971$ & $80,860,175$ & $243,693,113$ & $8,036,642$ & $291,114,905$ & $640,439,832$ & $11,074,441$ & $2,910,712,079$ & $2.78 \%$ & $0.28 \%$ & $3.05 \%$ \\
\hline $1995 \ldots \ldots \ldots \ldots \ldots$ & $1,652,914,466$ & $51,361,853$ & $293,652,709$ & $7,673,894$ & $307,306,050$ & $673,402,123$ & $8,217,497$ & $2,994,528,592$ & $1.72 \%$ & $0.26 \%$ & $1.97 \%$ \\
\hline$\ldots \ldots \ldots$ & $1,737,453,477$ & $57,343,476$ & $327,969,977$ & $8,351,904$ & $262,729,781$ & $674,728,546$ & $8,864,991$ & $3,077,442,152$ & $1.86 \%$ & $0.27 \%$ & $2.13 \%$ \\
\hline $1997 .$. & $1,787,806,344$ & $67,077,688$ & $337,233,538$ & $7,294,360$ & $283,624,806$ & $628,644,171$ & $10,842,237$ & $3,122,523,144$ & $2.15 \%$ & $0.23 \%$ & $2.38 \%$ \\
\hline$\ldots \ldots \ldots$ & $1,807,479,829$ & $95,048,609$ & $304,402,562$ & $10,391,091$ & $309,222,404$ & $673,702,104$ & $11,924,192$ & $3,212,170,791$ & $2.96 \%$ & $0.32 \%$ & $3.28 \%$ \\
\hline $1999 . \ldots \ldots \ldots \ldots$ & $1,765,429,778$ & $72,640,051$ & $289,692,790$ & $9,232,907$ & $295,639,305$ & $725,036,130$ & $7,660,493$ & $3,165,331,454$ & $2.29 \%$ & $0.29 \%$ & $2.59 \%$ \\
\hline \multicolumn{12}{|c|}{ Nonutility Generation } \\
\hline Year & Coal & Hydro & Natural Gas & Nuclear & Oil & Other & Total & $\begin{array}{c}\% \\
\text { Oil } \\
\end{array}$ & \multicolumn{2}{|c|}{$\begin{array}{c}\% \text { Oil: Utility } \\
\text { and Nonutility }\end{array}$} & \\
\hline 1989. . & $30,162,928$ & $5,871,784$ & $96,252,075$ & 47,186 & $5,542,985$ & $43,578,989$ & $181,455,947$ & $3.05 \%$ & \multicolumn{2}{|c|}{$\begin{array}{l}5.48 \% \\
4.06 \%\end{array}$} & \\
\hline $1990 \ldots$ & $30,699,089$ & $6,172,345$ & $113,582,794$ & 112,686 & $7,030,835$ & $52,677,408$ & $210,275,156$ & $3.34 \%$ & & \\
\hline $1991 \ldots \ldots \ldots \ldots \ldots$ & $38,772,705$ & $6,180,457$ & $127,767,083$ & 77,124 & $7,493,951$ & $59,981,559$ & $240,272,878$ & $3.12 \%$ & & & \\
\hline $1992 \ldots \ldots \ldots \ldots \ldots$ & $45,189,441$ & $9,351,974$ & $154,429,179$ & 65,094 & $10,507,858$ & $66,604,700$ & $286,148,245$ & $3.67 \%$ & \multicolumn{2}{|c|}{$\begin{array}{l}3.84 \% \\
3.16 \%\end{array}$} & \\
\hline $1993 . \ldots \ldots \ldots \ldots$ & $50,858,685$ & $11,395,678$ & $169,501,795$ & 76,041 & $12,814,453$ & $69,752,400$ & $314,399,053$ & $4.08 \%$ & \multicolumn{2}{|c|}{$3.42 \%$} & \\
\hline $1994 \ldots \ldots \ldots \ldots$ & $56,197,354$ & $13,094,665$ & $186,924,386$ & 51,987 & $14,463,980$ & $72,354,245$ & $343,086,617$ & $4.22 \%$ & \multicolumn{2}{|c|}{$3.18 \%$} & \\
\hline $1995 \ldots \ldots \ldots \ldots \ldots$ & $57,261,055$ & $14,626,063$ & $204,804,378$ & 0 & $14,415,816$ & $72,201,112$ & $363,308,424$ & $3.97 \%$ & \multicolumn{2}{|c|}{$2.19 \%$} & \\
\hline $1996 . \ldots \ldots \ldots \ldots$ & $58,256,728$ & $16,389,835$ & $207,417,140$ & 0 & $14,336,502$ & $73,151,380$ & $369,551,585$ & $3.88 \%$ & \multicolumn{2}{|c|}{$2.32 \%$} & \\
\hline $1997 . \ldots \ldots \ldots \ldots \ldots$ & $56,024,858$ & $17,675,113$ & $213,683,643$ & 0 & $14,974,500$ & $69,560,033$ & $371,918,149$ & $4.03 \%$ & \multicolumn{2}{|c|}{$2.56 \%$} & \\
\hline $1998 . \ldots \ldots \ldots \ldots$ & $66,466,303$ & $14,486,196$ & $239,992,299$ & 0 & $16,774,565$ & $67,982,905$ & $405,702,268$ & $4.13 \%$ & \multicolumn{2}{|c|}{$3.38 \%$} & \\
\hline
\end{tabular}

${ }^{a}$ Light oil is distillate fuel oil, and heavy oil is residual fuel oil.

Notes: EIA began collecting nonutility data in 1989 and is only final through 1998. Nonutilities do not directly report the split between light and heavy oil generation.

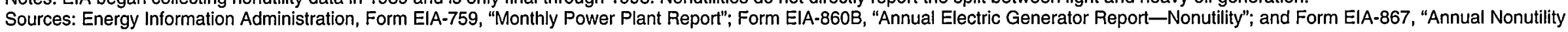
Power Producer Report." 
Table D2. Nonutility Diesel, Distillate Fuel Oil, and Residual Fuel Oil Consumption, 1991-1998 (Trillion Btu)

\begin{tabular}{|c|c|c|c|c|c|c|c|c|}
\hline Fuel & 1991 & 1992 & 1993 & 1994 & 1995 & 1996 & 1997 & 1998 \\
\hline \multicolumn{9}{|c|}{ National } \\
\hline Diesel. ... . & 0.000 & 1.111 & 0.776 & 2.344 & 1.997 & 1.759 & 3.468 & 62.036 \\
\hline Light $\mathrm{Oil}^{\mathrm{a}} \ldots$ & 25.445 & 26.390 & 40.368 & 49.314 & 42.773 & 29.442 & 43.559 & 61.277 \\
\hline Heavy Oila. . & 143.471 & 161.073 & 178.430 & 190.096 & 164.183 & 187.660 & 163.697 & 202.143 \\
\hline Total. . . . . . . . . & 168.916 & 188.574 & 219.574 & 241.754 & 208.952 & 218.862 & 210.725 & 325.456 \\
\hline Percent Light Oil ${ }^{\mathrm{a}} \ldots \ldots$ & $15.06 \%$ & $14.58 \%$ & $18.74 \%$ & $21.37 \%$ & $21.43 \%$ & $14.26 \%$ & $22.32 \%$ & $37.89 \%$ \\
\hline \multicolumn{9}{|c|}{ Census Division 1 - New England } \\
\hline Diesel. ... & 0.000 & 0.087 & 0.087 & 0.059 & 0.093 & 0.439 & 0.322 & 0.080 \\
\hline Light Oil ${ }^{\mathrm{a}} \ldots$ & 5.646 & 4.032 & 4.840 & 5.169 & 3.823 & 2.317 & 5.810 & 6.617 \\
\hline Heavy Oila & 37.415 & 46.032 & 51.329 & 53.033 & 43.297 & 55.141 & 42.672 & 47.435 \\
\hline Total. . . . . . . . . . . & 43.061 & 50.151 & 56.256 & 58.261 & 47.213 & 57.898 & 48.805 & 54.132 \\
\hline Percent Light Oil ${ }^{\mathrm{a}} \ldots \ldots$ & $13.11 \%$ & $8.21 \%$ & $8.76 \%$ & $8.97 \%$ & $8.29 \%$ & $4.76 \%$ & $12.57 \%$ & $12.37 \%$ \\
\hline \multicolumn{9}{|c|}{ Census Division 2 - Mid-Atlantic } \\
\hline Diesel. ... . & 0.000 & 0.120 & 0.090 & 0.130 & 0.692 & 0.230 & 0.152 & 0.272 \\
\hline Light Oil ${ }^{\mathrm{a}} .$. & 2.861 & 3.497 & 14.586 & 14.836 & 13.148 & 6.398 & 8.855 & 5.907 \\
\hline Heavy Oila & 28.156 & 25.877 & 25.072 & 29.826 & 19.231 & 20.985 & 17.358 & 13.365 \\
\hline Total. . . . . . . . & 31.016 & 29.493 & 39.747 & 44.792 & 33.071 & 27.614 & 26.365 & 19.543 \\
\hline Percent Light Oil ${ }^{\mathrm{a}}$. & $9.22 \%$ & $12.26 \%$ & $36.92 \%$ & $33.41 \%$ & $41.85 \%$ & $24.00 \%$ & $34.16 \%$ & $31.61 \%$ \\
\hline \multicolumn{9}{|c|}{ Census Division 3 - East North Central } \\
\hline Diesel. ... . & 0.000 & 0.038 & 0.047 & 0.038 & 0.023 & 0.439 & 0.534 & 0.084 \\
\hline Light Oil ${ }^{\mathrm{a}}$. & 0.434 & 0.613 & 1.069 & 2.405 & 2.027 & 1.881 & 1.162 & 11.834 \\
\hline Heavy Oila & 10.082 & 10.207 & 11.483 & 12.142 & 8.235 & 16.785 & 12.747 & 14.267 \\
\hline Total. . . . . . . . & 10.517 & 10.859 & 12.598 & 14.585 & 10.284 & 19.106 & 14.443 & 26.186 \\
\hline Percent Light Oil ${ }^{\mathrm{a}} \ldots . .$. & $4.13 \%$ & $6.00 \%$ & $8.86 \%$ & $16.75 \%$ & $19.93 \%$ & $12.15 \%$ & $11.74 \%$ & $45.52 \%$ \\
\hline
\end{tabular}

(19) Nonutilities do not directly report the split between light and heavy oil generation.

Sources: Energy Information Administration, Form EIA-759, "Monthly Power Plant Report"; Form EIA-860B, "Annual Electric Generator Report-Nonutility"; and Form EIA-867, "Annual Nonutility Power Producer Report." 
Table D3. Distillate Fuel Oil Consumption for Electricity Generation by Month, 1980-1999 (Barrels)

\begin{tabular}{|c|c|c|c|c|c|c|c|c|c|c|c|c|}
\hline Year & January & February & March & April & May & June & July & August & September & October & November & December \\
\hline \multicolumn{13}{|c|}{ Electric Utility Consumption } \\
\hline $1980 .$. & $3,203,286$ & $2,767,869$ & $2,195,969$ & $1,361,970$ & $1,523,699$ & $1,950,633$ & $3,828,468$ & $4,016,097$ & $2,149,294$ & $1,428,027$ & $2,310,439$ & $2,315,747$ \\
\hline$\ldots \ldots \ldots \ldots$ & $3,046,537$ & $2,242,266$ & $1,404,684$ & $1,356,357$ & $1,794,981$ & $2,704,752$ & $2,615,287$ & $1,421,908$ & $1,144,780$ & $1,123,018$ & $1,139,225$ & $1,319,180$ \\
\hline$\ldots \ldots \ldots \ldots$ & $3,130,528$ & $1,420,724$ & $1,303,949$ & $1,132,099$ & 991,248 & $1,052,983$ & $1,360,263$ & $1,052,720$ & 920,767 & 869,811 & $1,007,366$ & $1,094,257$ \\
\hline$\ldots \ldots \ldots \ldots$ & $1,110,424$ & 984,406 & 944,960 & $1,054,406$ & 936,947 & $1,019,790$ & $1,432,640$ & $1,542,904$ & $1,507,341$ & 869,613 & $1,075,166$ & $4,033,723$ \\
\hline$\ldots \ldots \ldots \ldots$ & $2,175,565$ & $1,017,589$ & $1,016,260$ & 830,822 & $1,009,891$ & $1,926,542$ & $1,258,544$ & $1,521,989$ & 995,602 & 965,315 & $1,326,327$ & $1,145,748$ \\
\hline$\ldots \ldots \ldots \ldots$ & $2,481,723$ & $1,333,055$ & 979,639 & 910,681 & 962,052 & $1,111,396$ & $1,109,123$ & $1,337,600$ & 978,768 & 969,455 & $1,021,161$ & $1,440,044$ \\
\hline$\ldots \ldots \ldots \ldots$ & $1,688,473$ & $1,099,686$ & 927,837 & 892,584 & $1,209,008$ & $1,390,314$ & $1,727,407$ & $1,149,790$ & $1,106,992$ & 869,279 & $1,075,512$ & $1,189,023$ \\
\hline$\ldots \ldots \ldots \ldots$ & $1,316,961$ & $1,148,510$ & $1,226,721$ & $1,033,183$ & $1,182,806$ & $1,406,711$ & $2,074,848$ & $1,647,568$ & 924,170 & 891,454 & $1,307,064$ & $1,206,905$ \\
\hline 1988. & $2,299,165$ & $1,136,519$ & $1,044,761$ & 805,213 & 998,067 & $1,856,758$ & $1,942,820$ & $3,207,212$ & $1,004,284$ & $1,099,674$ & $1,201,673$ & $2,172,828$ \\
\hline 1989. & $2,054,576$ & $2,426,944$ & $2,690,518$ & $1,045,381$ & $1,522,137$ & $2,069,505$ & $2,179,763$ & $1,530,441$ & $1,526,021$ & $1,180,010$ & $1,484,111$ & $5,781,277$ \\
\hline 1990. & $1,236,942$ & 974,012 & 915,910 & $1,035,276$ & $1,146,358$ & $1,554,847$ & $1,614,610$ & $1,618,368$ & $1,317,642$ & $1,185,978$ & 910,261 & $1,312,892$ \\
\hline 1991. & $1,187,303$ & 803,666 & 827,774 & $1,018,718$ & $1,814,465$ & $1,122,367$ & $1,218,129$ & $1,379,572$ & $1,165,147$ & 902,337 & $1,146,089$ & $1,143,410$ \\
\hline$\ldots \ldots \ldots$ & $1,103,110$ & 806,236 & 843,393 & 810,841 & 842,662 & $1,076,973$ & $1,427,819$ & $1,011,487$ & 848,761 & 792,314 & $1,003,591$ & 988,506 \\
\hline 1993. . . . . . . . . & $1,013,193$ & 935,016 & $1,276,928$ & 818,766 & 867,766 & $1,032,707$ & $1,816,950$ & $1,566,013$ & $1,030,726$ & 897,268 & 885,856 & $1,026,776$ \\
\hline $1994 \ldots \ldots \ldots \ldots \ldots$ & $3,708,634$ & $1,396,753$ & $1,014,052$ & $1,041,314$ & $1,163,764$ & $1,871,348$ & $1,529,794$ & $1,020,993$ & 869,853 & 810,684 & 862,505 & $1,048,118$ \\
\hline $1995 \ldots \ldots \ldots \ldots \ldots$ & $1,056,994$ & $1,316,380$ & 906,942 & 917,867 & $1,133,485$ & $1,194,824$ & $1,878,603$ & $2,853,030$ & 903,066 & 932,183 & $1,051,046$ & $1,421,037$ \\
\hline 1996. . & $1,912,533$ & $2,480,281$ & $1,545,042$ & 978,254 & $1,345,936$ & $1,079,182$ & $1,293,874$ & $1,109,970$ & $1,066,205$ & 937,095 & 997,098 & $2,146,357$ \\
\hline 1997. & $1,622,809$ & 790,182 & 834,433 & 982,828 & 943,462 & $1,348,491$ & $2,492,659$ & $1,300,740$ & 972,977 & $1,052,854$ & $1,020,488$ & $1,794,679$ \\
\hline 1998. . . & 937,723 & 753,648 & $1,179,683$ & 963,474 & $1,991,844$ & $3,102,943$ & $3,362,457$ & $3,044,973$ & $2,604,877$ & 974,845 & 991,126 & $2,133,607$ \\
\hline $1999 \ldots \ldots \ldots \ldots \ldots$ & $2,250,700$ & 826,918 & $1,013,812$ & $1,517,235$ & $1,208,081$ & $1,856,872$ & $4,500,679$ & $2,845,033$ & $1,166,132$ & 966,986 & 856,043 & $1,015,676$ \\
\hline \multicolumn{13}{|c|}{ Nonutility Consumption } \\
\hline 1980. & 18.659 & 16.123 & 12.792 & 7.933 & 8.876 & 11.362 & 22.301 & 23.394 & 12.520 & 8.318 & 13.458 & 13.489 \\
\hline 1981. & 17.746 & 13.061 & 8.182 & 7.901 & 10.456 & 15.755 & 15.234 & 8.283 & 6.668 & 6.542 & 6.636 & 7.684 \\
\hline$\ldots \ldots \ldots$ & 18.235 & 8.276 & 7.596 & 6.594 & 5.774 & 6.134 & 7.924 & 6.132 & 5.363 & 5.067 & 5.868 & 6.374 \\
\hline $1983 \ldots \ldots \ldots \ldots \ldots$ & 6.468 & 5.734 & 5.504 & 6.142 & 5.458 & 5.940 & 8.345 & 8.987 & 8.780 & 5.065 & 6.263 & 23.496 \\
\hline $1984 \ldots \ldots \ldots \ldots \ldots$ & 12.673 & 5.927 & 5.920 & 4.840 & 5.883 & 11.222 & 7.331 & 8.866 & 5.799 & 5.623 & 7.726 & 6.674 \\
\hline $1985 . \ldots$ & 14.456 & 7.765 & 5.706 & 5.305 & 5.604 & 6.474 & 6.461 & 7.792 & 5.701 & 5.647 & 5.948 & 8.388 \\
\hline $1986 . .$. & 9.835 & 6.406 & 5.405 & 5.199 & 7.042 & 8.099 & 10.062 & 6.698 & 6.448 & 5.064 & 6.265 & 6.926 \\
\hline $1987 \ldots$ & 7.671 & 6.690 & 7.146 & 6.018 & 6.890 & 8.194 & 12.086 & 9.597 & 5.383 & 5.193 & 7.614 & 7.030 \\
\hline $1988 . \ldots$ & 13.393 & 6.620 & 6.086 & 4.690 & 5.814 & 10.816 & 11.317 & 18.682 & 5.850 & 6.406 & 7.000 & 12.657 \\
\hline $1989 . \ldots \ldots \ldots$ & 11.968 & 14.137 & 15.672 & 6.089 & 8.866 & 12.055 & 12.697 & 8.915 & 8.889 & 6.874 & 8.645 & 33.676 \\
\hline $1990 \ldots \ldots \ldots$ & 7.205 & 5.674 & 5.335 & 6.030 & 6.678 & 9.057 & 9.405 & 9.427 & 7.675 & 6.908 & 5.302 & 7.648 \\
\hline $1991 \ldots \ldots \ldots$ & 6.916 & 4.681 & 4.822 & 5.934 & 10.569 & 6.538 & 7.096 & 8.036 & 6.787 & 5.256 & 6.676 & 6.660 \\
\hline $1992 \ldots \ldots \ldots$ & 6.426 & 4.696 & 4.913 & 4.723 & 4.909 & 6.273 & 8.317 & 5.892 & 4.944 & 4.615 & 5.846 & 5.758 \\
\hline $1993 . \ldots$ & 5.902 & 5.446 & 7.438 & 4.769 & 5.055 & 6.016 & 10.584 & 9.122 & 6.004 & 5.227 & 5.160 & 5.981 \\
\hline $1994 \ldots \ldots \ldots \ldots \ldots$ & 21.603 & 8.136 & 5.907 & 6.066 & 6.779 & 10.901 & 8.911 & 5.947 & 5.067 & 4.722 & 5.024 & 6.105 \\
\hline $1995 \ldots \ldots \ldots \ldots \ldots$ & 6.157 & 7.668 & 5.283 & 5.347 & 6.603 & 6.960 & 10.943 & 16.619 & 5.260 & 5.430 & 6.122 & 8.278 \\
\hline $1996 \ldots \ldots \ldots \ldots \ldots$ & 11.141 & 14.448 & 9.000 & 5.698 & 7.840 & 6.286 & 7.537 & 6.466 & 6.211 & 5.459 & 5.808 & 12.503 \\
\hline $1997 \ldots \ldots \ldots \ldots \ldots$ & 9.453 & 4.603 & 4.861 & 5.725 & 5.496 & 7.855 & 14.520 & 7.577 & 5.668 & 6.133 & 5.944 & 10.454 \\
\hline $1998 \ldots \ldots \ldots \ldots \ldots$ & 5.462 & 4.390 & 6.872 & 5.612 & 11.602 & 18.075 & 19.586 & 17.737 & 15.173 & 5.678 & 5.773 & 12.428 \\
\hline $1999 \ldots \ldots \ldots \ldots \ldots$ & 13.110 & 4.817 & 5.905 & 8.838 & 7.037 & 10.816 & 26.216 & 16.572 & 6.793 & 5.633 & 4.986 & 5.916 \\
\hline
\end{tabular}

Note: EIA began collecting nonutility data in 1989 and is only final through 1998. Nonutilities do not directly report the split between distillate fuel oil and residual fuel oil generation.

$\simeq \quad$ Power Producer Report." 
Table D4. Electricity Generation by Fuel, Census Division 1, 1980-1999 (Megawatthours)

\begin{tabular}{|c|c|c|c|c|c|c|c|c|c|c|c|}
\hline \multicolumn{12}{|c|}{ Electric Utility Generation } \\
\hline Year & Coal & Heavy Oil ${ }^{\mathrm{a}}$ & Hydro & Light Oil $^{\mathrm{a}}$ & Natural Gas & Nuclear & Other & Total & $\begin{array}{c}\% \\
\text { Heavy } \\
\text { Oil }^{\mathrm{a}}\end{array}$ & $\begin{array}{c}\% \\
\text { Light } \\
\text { Oil }\end{array}$ & $\begin{array}{c}\% \\
\text { Oil } \\
\end{array}$ \\
\hline $1980 \ldots \ldots \ldots \ldots$ & $4,538,654$ & $46,698,737$ & $3,404,694$ & 484,627 & 576,169 & $22,450,207$ & 48,941 & $78,202,029$ & $59.72 \%$ & $0.62 \%$ & $60.34 \%$ \\
\hline $1981 \ldots \ldots \ldots \ldots$ & $4,467,540$ & $40,958,382$ & $4,640,841$ & 237,925 & 795,669 & $25,784,625$ & 26,089 & $76,911,071$ & $53.25 \%$ & $0.31 \%$ & $53.56 \%$ \\
\hline $1982 \ldots \ldots \ldots \ldots$ & $11,199,301$ & $33,086,247$ & $4,397,879$ & 310,927 & $1,471,006$ & $26,496,606$ & 43,436 & $77,005,402$ & $42.97 \%$ & $0.40 \%$ & $43.37 \%$ \\
\hline$\ldots \ldots \ldots$ & $11,927,216$ & $32,281,816$ & $4,686,480$ & 383,976 & $2,584,300$ & $26,251,134$ & 50,480 & $78,165,402$ & $41.30 \%$ & $0.49 \%$ & $41.79 \%$ \\
\hline$\ldots \ldots \ldots \ldots$ & $14,622,781$ & $33,251,450$ & $4,599,830$ & 718,752 & $3,575,159$ & $23,785,862$ & 177,586 & $80,731,420$ & $41.19 \%$ & $0.89 \%$ & $42.08 \%$ \\
\hline$\ldots \ldots \ldots$ & $16,167,923$ & $28,486,302$ & $4,003,191$ & 568,504 & $4,673,852$ & $27,207,862$ & 280,138 & $81,387,772$ & $35.00 \%$ & $0.70 \%$ & $35.70 \%$ \\
\hline$\ldots \ldots \ldots \ldots$ & $14,149,446$ & $36,919,358$ & $4,808,530$ & 823,824 & $1,376,579$ & $29,387,580$ & 84,729 & $87,550,046$ & $42.17 \%$ & $0.94 \%$ & $43.11 \%$ \\
\hline$\ldots \ldots \ldots \ldots$ & $16,673,651$ & $31,867,359$ & $4,108,658$ & 963,434 & $4,744,476$ & $29,255,747$ & 155,930 & $87,769,255$ & $36.31 \%$ & $1.10 \%$ & $37.41 \%$ \\
\hline$\ldots \ldots \ldots \ldots$ & $16,979,148$ & $36,670,879$ & $3,819,144$ & $1,139,922$ & $1,933,230$ & $32,498,780$ & 341,927 & $93,383,030$ & $39.27 \%$ & $1.22 \%$ & $40.49 \%$ \\
\hline$\ldots \ldots \ldots \ldots$ & $17,248,003$ & $35,784,662$ & $4,333,616$ & $1,253,146$ & $5,193,375$ & $33,126,123$ & 501,728 & $97,440,653$ & $36.72 \%$ & $1.29 \%$ & $38.01 \%$ \\
\hline$\ldots \ldots \ldots$ & $16,583,321$ & $27,257,610$ & $5,603,383$ & 477,902 & $6,250,712$ & $37,403,556$ & 515,784 & $94,092,268$ & $28.97 \%$ & $0.51 \%$ & $29.48 \%$ \\
\hline$\ldots \ldots \ldots$ & $17,147,179$ & $25,860,842$ & $4,739,749$ & 531,833 & $4,360,009$ & $33,820,053$ & 548,714 & $87,008,379$ & $29.72 \%$ & $0.61 \%$ & $30.33 \%$ \\
\hline$\ldots \ldots \ldots$ & $16,284,393$ & $20,969,720$ & $3,959,435$ & 322,847 & $4,108,822$ & $38,473,922$ & 466,194 & $84,585,333$ & $24.79 \%$ & $0.38 \%$ & $25.17 \%$ \\
\hline$\ldots \ldots \ldots$ & $14,986,976$ & $17,102,047$ & $3,760,414$ & 273,416 & $3,001,972$ & $44,299,286$ & 470,502 & $83,894,613$ & $20.39 \%$ & $0.33 \%$ & $20.71 \%$ \\
\hline 1994. . & $15,495,426$ & $14,634,520$ & $4,124,901$ & 374,733 & $4,623,652$ & $41,169,782$ & 510,645 & $80,933,659$ & $18.08 \%$ & $0.46 \%$ & $18.55 \%$ \\
\hline 1995. . & $16,223,448$ & $10,676,063$ & $3,613,701$ & 449,614 & $8,836,651$ & $35,670,207$ & 531,193 & $76,000,877$ & $14.05 \%$ & $0.59 \%$ & $14.64 \%$ \\
\hline 1996. . & $17,178,120$ & $12,632,757$ & $5,401,061$ & 368,772 & $8,648,431$ & $30,255,125$ & 572,390 & $75,056,656$ & $16.83 \%$ & $0.49 \%$ & $17.32 \%$ \\
\hline 1997. . & $19,123,961$ & $22,184,709$ & $4,508,236$ & 309,665 & $10,340,158$ & $16,432,023$ & 601,094 & $73,499,846$ & $30.18 \%$ & $0.42 \%$ & $30.60 \%$ \\
\hline 1998. . & $13,164,281$ & $21,376,314$ & $4,359,462$ & 382,809 & $4,859,433$ & $20,686,136$ & 572,847 & $65,401,282$ & $32.68 \%$ & $0.59 \%$ & $33.27 \%$ \\
\hline $1999 . \ldots \ldots \ldots \ldots$ & $4,760,016$ & $7,993,338$ & $1,491,777$ & 272,531 & $2,103,337$ & $27,341,549$ & 681,114 & $44,643,662$ & $17.90 \%$ & $0.61 \%$ & $18.52 \%$ \\
\hline \multicolumn{12}{|c|}{ Nonutility Generation } \\
\hline Year & Coal & Hydro & Natural Gas & Nuclear & Oil & Other & Total & $\begin{array}{r}\% \\
\text { Oil } \\
\end{array}$ & $\begin{array}{l}\% \text { Oil: } \\
\text { and No }\end{array}$ & $\begin{array}{l}\text { Jtility } \\
\text { Iutility }\end{array}$ & \\
\hline 1989. . & 363,447 & $2,024,297$ & 687,780 & 0 & $1,627,685$ & $5,841,094$ & $10,544,303$ & $15.44 \%$ & 35.8 & & \\
\hline 1990. . & $1,808,396$ & $2,349,897$ & $1,571,217$ & 0 & $1,541,056$ & $6,595,839$ & $13,866,406$ & $11.11 \%$ & 27.1 & & \\
\hline 1991. . & $2,384,479$ & $2,241,520$ & $6,508,509$ & 0 & $1,254,397$ & $7,215,462$ & $19,604,366$ & $6.40 \%$ & 25.9 & & \\
\hline 1992. . & $2,248,528$ & $2,667,431$ & $10,726,313$ & 0 & $1,459,459$ & $8,034,104$ & $25,135,836$ & $5.81 \%$ & 20.7 & & \\
\hline $1993 . \ldots \ldots \ldots \ldots$ & $2,267,749$ & $2,500,641$ & $12,091,148$ & 0 & $1,708,635$ & $8,637,933$ & $27,206,106$ & $6.28 \%$ & 17.1 & & \\
\hline $1994 . \ldots \ldots \ldots \ldots$ & $2,417,117$ & $2,682,306$ & $13,504,443$ & 0 & $1,876,056$ & $8,382,485$ & $28,862,406$ & $6.50 \%$ & 15.3 & & \\
\hline $1995 . \ldots \ldots \ldots \ldots$ & $2,254,075$ & $2,535,751$ & $13,033,773$ & 0 & $1,796,956$ & $8,668,585$ & $28,289,140$ & $6.35 \%$ & 12.3 & & \\
\hline $1996 . \ldots \ldots \ldots \ldots$ & $2,142,117$ & $3,202,504$ & $13,122,453$ & 0 & $1,721,262$ & $8,604,372$ & $28,792,708$ & $5.98 \%$ & 14.1 & & \\
\hline $1997 \ldots \ldots \ldots \ldots \ldots$ & $2,395,707$ & $2,946,283$ & $13,677,824$ & 0 & $1,523,053$ & $8,403,938$ & $28,946,805$ & $5.26 \%$ & 23.4 & & \\
\hline $1998 \ldots \ldots \ldots \ldots \ldots$ & $5,608,848$ & $3,261,759$ & $19,481,471$ & 0 & $3,902,364$ & $7,617,508$ & $39,871,951$ & $9.79 \%$ & 24.3 & $8 \%$ & \\
\hline
\end{tabular}

a ${ }^{\mathrm{a} i g h t}$ oil is distillate fuel oil, and heavy oil is residual fuel oil.

Note: EIA began collecting nonutility data in 1989 and is only final through 1998 . Nonutilities do not directly report the split between light and heavy oil generation.

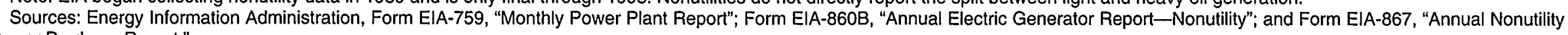
Power Producer Report." 
Table D5. Electricity Generation by Fuel, Census Division 2, 1980-1999 (Megawatthours)

\begin{tabular}{|c|c|c|c|c|c|c|c|c|c|c|c|}
\hline \multicolumn{12}{|c|}{ Electric Utility Generation } \\
\hline Year & Coal & Heavy $\mathrm{Oil}^{\mathrm{a}}$ & Hydro & Light Oil $^{\mathrm{a}}$ & Natural Gas & Nuclear & Other & Total & $\begin{array}{c}\% \\
\text { Heavy } \\
\text { Oil }^{\mathrm{a}}\end{array}$ & $\begin{array}{c}\% \\
\text { Light } \\
\text { Oil }^{\mathrm{a}}\end{array}$ & $\begin{array}{c}\% \\
\text { Oil }\end{array}$ \\
\hline$\ldots \ldots \ldots \ldots$ & $119,530,366$ & $54,799,580$ & $26,689,332$ & $2,520,929$ & $17,867,007$ & $38,993,730$ & 133,105 & $260,534,049$ & $21.03 \%$ & $0.97 \%$ & $22.00 \%$ \\
\hline$\ldots \ldots \ldots \ldots$ & $113,329,898$ & $50,507,443$ & $26,083,217$ & $1,795,135$ & $18,933,659$ & $43,395,362$ & 110,489 & $254,155,203$ & $19.87 \%$ & $0.71 \%$ & $20.58 \%$ \\
\hline $1982 . \ldots \ldots \ldots \ldots$ & $116,349,135$ & $42,764,535$ & $26,932,565$ & $1,372,440$ & $19,836,038$ & $44,949,012$ & 169,701 & $252,373,426$ & $16.94 \%$ & $0.54 \%$ & $17.49 \%$ \\
\hline $1983 . \ldots \ldots \ldots \ldots$ & $119,802,570$ & $48,135,831$ & $27,100,726$ & $1,762,981$ & $21,218,825$ & $37,422,096$ & 420,411 & $255,863,440$ & $18.81 \%$ & $0.69 \%$ & $19.50 \%$ \\
\hline $1984 \ldots \ldots \ldots \ldots$ & $122,568,700$ & $41,372,191$ & $27,783,222$ & $1,822,821$ & $24,099,052$ & $48,360,207$ & 380,262 & $266,386,455$ & $15.53 \%$ & $0.68 \%$ & $16.22 \%$ \\
\hline $1985 . \ldots \ldots \ldots \ldots$ & $127,375,546$ & $34,907,491$ & $27,679,556$ & $1,313,144$ & $21,475,013$ & $68,094,447$ & 309,716 & $281,154,913$ & $12.42 \%$ & $0.47 \%$ & $12.88 \%$ \\
\hline$\ldots \ldots \ldots$ & $119,366,734$ & $43,423,184$ & $30,642,328$ & $1,580,480$ & $15,592,728$ & $76,675,061$ & 382,382 & $287,662,897$ & $15.10 \%$ & $0.55 \%$ & $15.64 \%$ \\
\hline$\ldots \ldots \ldots$ & $128,211,283$ & $39,747,541$ & $28,364,881$ & $2,008,663$ & $22,932,655$ & $80,605,746$ & 446,317 & $302,317,086$ & $13.15 \%$ & $0.66 \%$ & $13.81 \%$ \\
\hline $1988 \ldots \ldots \ldots \ldots$ & $136,162,930$ & $49,739,679$ & $24,383,703$ & $2,577,385$ & $18,499,292$ & $85,927,934$ & 515,129 & $317,806,052$ & $15.65 \%$ & $0.81 \%$ & $16.46 \%$ \\
\hline$\ldots \ldots \ldots \ldots$ & $139,529,773$ & $50,785,260$ & $24,946,737$ & $3,508,265$ & $22,084,968$ & $85,044,763$ & 488,917 & $326,388,683$ & $15.56 \%$ & $1.07 \%$ & $16.63 \%$ \\
\hline $1990 \ldots \ldots \ldots \ldots$ & $133,670,746$ & $37,441,953$ & $27,301,259$ & $1,388,888$ & $25,423,894$ & $105,180,794$ & 419,199 & $330,826,733$ & $11.32 \%$ & $0.42 \%$ & $11.74 \%$ \\
\hline $1991 \ldots \ldots \ldots \ldots \ldots$ & $130,534,488$ & $31,728,748$ & $25,406,213$ & $1,149,704$ & $25,535,125$ & $110,730,570$ & 387,822 & $325,472,670$ & $9.75 \%$ & $0.35 \%$ & $10.10 \%$ \\
\hline $1992 . \ldots \ldots \ldots \ldots$ & $132,529,150$ & $19,948,841$ & $26,670,800$ & 655,442 & $23,323,852$ & $105,882,758$ & 418,838 & $309,429,681$ & $6.45 \%$ & $0.21 \%$ & $6.66 \%$ \\
\hline$\ldots \ldots \ldots$ & $127,675,591$ & $18,860,089$ & $27,988,973$ & 793,362 & $19,943,469$ & $111,152,035$ & 386,291 & $306,799,810$ & $6.15 \%$ & $0.26 \%$ & $6.41 \%$ \\
\hline$\ldots \ldots \ldots$ & $119,457,273$ & $16,062,213$ & $26,545,193$ & $1,343,062$ & $22,305,985$ & $118,567,584$ & 442,238 & $304,723,548$ & $5.27 \%$ & $0.44 \%$ & $5.71 \%$ \\
\hline$\ldots \ldots \ldots$ & $121,848,141$ & $9,989,369$ & $23,969,141$ & $1,265,934$ & $29,965,394$ & $109,603,224$ & 548,859 & $297,190,062$ & $3.36 \%$ & $0.43 \%$ & $3.79 \%$ \\
\hline$\ldots \ldots \ldots$ & $127,128,343$ & $11,226,123$ & $27,494,718$ & $1,327,034$ & $16,435,561$ & $114,925,730$ & 635,350 & $299,172,859$ & $3.75 \%$ & $0.44 \%$ & $4.20 \%$ \\
\hline$\ldots \ldots \ldots$ & $134,019,227$ & $9,213,301$ & $28,929,951$ & $1,016,348$ & $24,093,598$ & $111,132,280$ & 621,853 & $309,026,558$ & $2.98 \%$ & $0.33 \%$ & $3.31 \%$ \\
\hline $1998 \ldots \ldots \ldots \ldots$ & $135,606,564$ & $17,188,098$ & $28,003,634$ & $1,287,133$ & $23,339,326$ & $119,595,071$ & 634,949 & $325,654,775$ & $5.28 \%$ & $0.40 \%$ & $5.67 \%$ \\
\hline $1999 . \ldots \ldots \ldots \ldots$ & $102,627,689$ & $13,547,180$ & $20,928,811$ & $1,392,525$ & $21,190,580$ & $136,874,310$ & 371,488 & $296,932,583$ & $4.56 \%$ & $0.47 \%$ & $5.03 \%$ \\
\hline \multicolumn{12}{|c|}{ Nonutility Generation } \\
\hline Year & Coal & Hydro & Natural Gas & Nuclear & Oil & Other & Total & $\begin{array}{l}\% \\
\text { Oil } \\
\end{array}$ & \multicolumn{2}{|c|}{$\begin{array}{l}\% \text { Oil: Utility } \\
\text { and Nonutility }\end{array}$} & \\
\hline$\ldots \ldots \ldots \ldots$ & $4,593,724$ & 734,125 & $5,034,383$ & 0 & $1,003,274$ & $1,759,692$ & $13,125,197$ & $7.64 \%$ & \multicolumn{2}{|c|}{$16.29 \%$} & \\
\hline $1990 . \ldots$ & $4,970,933$ & 959,516 & $6,971,914$ & 0 & $1,130,902$ & $2,743,948$ & $16,777,214$ & $6.74 \%$ & \multicolumn{2}{|c|}{$11.50 \%$} & \\
\hline $1991 \ldots \ldots \ldots \ldots$ & $7,357,624$ & 868,084 & $10,722,609$ & 0 & $1,100,758$ & $3,902,716$ & $23,951,791$ & $4.60 \%$ & \multicolumn{2}{|c|}{$9.72 \%$} & \\
\hline $1992 \ldots \ldots \ldots \ldots$ & $9,278,947$ & $1,897,010$ & $21,839,871$ & 0 & $1,150,874$ & $5,251,611$ & $39,418,313$ & $2.92 \%$ & \multicolumn{2}{|c|}{$6.24 \%$} & \\
\hline $1993 . \ldots \ldots \ldots \ldots$ & $10,427,744$ & $1,706,811$ & $27,550,666$ & 0 & $1,629,765$ & $5,662,383$ & $46,977,369$ & $3.47 \%$ & \multicolumn{2}{|c|}{$6.02 \%$} & \\
\hline $1994 . \ldots \ldots \ldots \ldots \ldots$ & $11,556,854$ & $1,858,441$ & $33,171,098$ & 0 & $2,134,559$ & $5,701,588$ & $54,422,540$ & $3.92 \%$ & \multicolumn{2}{|c|}{$5.44 \%$} & \\
\hline $1995 . \ldots \ldots \ldots \ldots$ & $14,037,534$ & $1,568,617$ & $43,855,830$ & 0 & $1,718,721$ & $6,068,114$ & $67,248,816$ & $2.56 \%$ & \multicolumn{2}{|c|}{$3.56 \%$} & \\
\hline $1996 . \ldots \ldots \ldots \ldots$ & $14,749,887$ & $2,313,414$ & $41,789,350$ & 0 & $1,378,641$ & $6,109,904$ & $66,341,196$ & $2.08 \%$ & \multicolumn{2}{|c|}{$3.81 \%$} & \\
\hline $1997 \ldots \ldots \ldots \ldots \ldots$ & $13,681,606$ & $2,143,932$ & $42,943,210$ & 0 & $1,475,078$ & $5,901,798$ & $66,145,624$ & $2.23 \%$ & \multicolumn{2}{|c|}{$3.12 \%$} & \\
\hline $1998 \ldots \ldots \ldots \ldots$ & $13,878,090$ & $1,943,842$ & $40,673,523$ & 0 & $1,160,953$ & $6,042,125$ & $63,698,534$ & $1.82 \%$ & \multicolumn{2}{|c|}{$5.04 \%$} & \\
\hline
\end{tabular}

${ }^{a}$ Light oil is distillate fuel oil, and heavy oil is residual fuel oil.

Note: ElA began collecting nonutility data in 1989 and is only final through 1998. Nonutilities do not directly report the split between light and heavy oil generation.

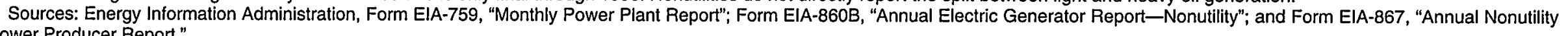
Power Producer Report." 
Table D6. Electricity Generation by Fuel, Census Division 3, 1980-1999 (Megawatthours)

\begin{tabular}{|c|c|c|c|c|c|c|c|c|c|c|c|}
\hline \multicolumn{12}{|c|}{ Electric Utility Generation } \\
\hline Year & Coal & Heavy Oil ${ }^{a}$ & Hydro & Light Oil ${ }^{\mathrm{a}}$ & Natural Gas & Nuclear & Other & Total & $\begin{array}{c}\% \\
\text { Heavy } \\
\text { Oil }^{\mathbf{a}}\end{array}$ & $\begin{array}{c}\% \\
\text { Light } \\
\text { Oil }^{\mathrm{a}}\end{array}$ & $\begin{array}{l}\% \\
\text { Oil } \\
\end{array}$ \\
\hline 1980. & $318,737,720$ & $12,369,798$ & $3,542,335$ & $2,105,695$ & $4,489,256$ & $55,662,818$ & 65,731 & $396,973,353$ & $3.12 \%$ & $0.53 \%$ & $3.65 \%$ \\
\hline$\ldots \ldots$ & $314,160,401$ & $7,870,170$ & $3,638,526$ & $1,522,682$ & $3,108,490$ & $60,675,078$ & 71,015 & $391,046,362$ & $2.01 \%$ & $0.39 \%$ & $2.40 \%$ \\
\hline$\ldots \ldots$ & $300,605,571$ & $4,805,427$ & $3,798,062$ & $1,219,126$ & $2,105,608$ & $56,121,538$ & 79,231 & $368,734,563$ & $1.30 \%$ & $0.33 \%$ & $1.63 \%$ \\
\hline 1983. & $316,788,766$ & $3,366,904$ & $4,081,849$ & $1,034,882$ & $2,206,395$ & $58,606,609$ & 68,166 & $386,153,571$ & $0.87 \%$ & $0.27 \%$ & $1.14 \%$ \\
\hline 1984. & $331,113,923$ & $2,324,018$ & $3,757,723$ & 977,890 & $1,465,988$ & $64,112,071$ & 288,731 & $404,040,344$ & $0.58 \%$ & $0.24 \%$ & $0.82 \%$ \\
\hline$\ldots \ldots \ldots$ & $335,639,564$ & $1,039,246$ & $3,888,392$ & $1,099,962$ & $1,086,124$ & $65,480,464$ & 359,616 & $408,593,368$ & $0.25 \%$ & $0.27 \%$ & $0.52 \%$ \\
\hline $1986 \ldots \ldots \ldots \ldots \ldots$ & $339,512,009$ & $2,414,521$ & $3,567,489$ & 973,161 & $1,508,457$ & $66,094,347$ & 515,749 & $414,585,733$ & $0.58 \%$ & $0.23 \%$ & $0.82 \%$ \\
\hline $1987 .$. & $348,953,676$ & $1,806,007$ & $2,504,834$ & 916,707 & 940,007 & $83,406,568$ & 660,942 & $439,188,741$ & $0.41 \%$ & $0.21 \%$ & $0.62 \%$ \\
\hline$\ldots \ldots \ldots$ & $350,815,830$ & $1,778,323$ & $2,389,259$ & $1,049,361$ & $1,579,892$ & $106,892,852$ & 692,867 & $465,198,384$ & $0.38 \%$ & $0.23 \%$ & $0.61 \%$ \\
\hline$\ldots \ldots$ & $355,688,019$ & $1,515,202$ & $2,698,089$ & 929,653 & $1,524,204$ & $119,641,214$ & 719,114 & $482,715,495$ & $0.31 \%$ & $0.19 \%$ & $0.51 \%$ \\
\hline$\ldots \ldots \ldots$ & $362,333,020$ & 766,901 & $3,263,316$ & 922,275 & $2,277,257$ & $115,387,612$ & 884,973 & $485,835,354$ & $0.16 \%$ & $0.19 \%$ & $0.35 \%$ \\
\hline$\ldots \ldots \ldots \ldots$ & $365,922,735$ & $1,120,295$ & $3,722,686$ & 958,609 & $3,404,539$ & $124,711,513$ & 620,891 & $500,461,268$ & $0.22 \%$ & $0.19 \%$ & $0.42 \%$ \\
\hline$\ldots \ldots \ldots$ & $360,265,015$ & 585,362 & $3,858,054$ & 714,599 & $2,899,912$ & $118,603,736$ & 636,749 & $487,563,427$ & $0.12 \%$ & $0.15 \%$ & $0.27 \%$ \\
\hline$\ldots \ldots \ldots$ & $376,682,351$ & 933,539 & $3,728,314$ & 931,864 & $2,794,372$ & $128,373,693$ & 336,432 & $513,780,565$ & $0.18 \%$ & $0.18 \%$ & $0.36 \%$ \\
\hline 1994. & $383,432,200$ & $1,401,292$ & $3,280,251$ & $1,132,569$ & $4,547,292$ & $109,267,496$ & 348,533 & $503,409,633$ & $0.28 \%$ & $0.22 \%$ & $0.50 \%$ \\
\hline 1995. & $388,842,356$ & 954,914 & $3,594,239$ & $1,006,164$ & $6,014,150$ & $130,666,901$ & 626,623 & $531,705,347$ & $0.18 \%$ & $0.19 \%$ & $0.37 \%$ \\
\hline 1996. & $408,295,640$ & 936,078 & $4,104,902$ & 914,545 & $3,723,063$ & $120,644,464$ & 761,384 & $539,380,076$ & $0.17 \%$ & $0.17 \%$ & $0.34 \%$ \\
\hline$\ldots \ldots \ldots$ & $416,284,507$ & 697,443 & $3,926,264$ & 922,217 & $5,995,918$ & $92,229,327$ & 922,559 & $520,978,235$ & $0.13 \%$ & $0.18 \%$ & $0.31 \%$ \\
\hline $1998 \ldots \ldots \ldots \ldots$ & $418,626,920$ & $1,153,843$ & $2,805,713$ & $1,160,522$ & $9,116,698$ & $93,962,727$ & $1,342,695$ & $528,169,118$ & $0.22 \%$ & $0.22 \%$ & $0.44 \%$ \\
\hline $1999 \ldots \ldots \ldots \ldots$ & $408,764,344$ & $1,166,331$ & $2,007,648$ & $1,274,409$ & $7,793,638$ & $123,863,436$ & $1,092,646$ & $545,962,452$ & $0.21 \%$ & $0.23 \%$ & $0.45 \%$ \\
\hline \multicolumn{12}{|c|}{ Nonutility Generation } \\
\hline Year & Coal & Hydro & Natural Gas & Nuclear & Oil & Other & Total & $\begin{array}{l}\% \\
\text { Oil }\end{array}$ & \multicolumn{2}{|c|}{$\begin{array}{l}\% \text { Oil: Utility } \\
\text { and Nonutility }\end{array}$} & \\
\hline 1989. & $5,482,204$ & 196,841 & $5,239,145$ & 0 & 389,296 & $2,207,364$ & $13,514,850$ & $2.88 \%$ & \multicolumn{2}{|c|}{$0.57 \%$} & \\
\hline 1990. & $5,248,707$ & 239,601 & $11,536,178$ & 0 & 461,894 & $2,638,400$ & $20,124,779$ & $2.30 \%$ & \multicolumn{2}{|c|}{$0.43 \%$} & \\
\hline 1991. & $5,236,546$ & 263,591 & $11,796,682$ & 0 & 355,624 & $3,034,696$ & $20,687,139$ & $1.72 \%$ & \multicolumn{2}{|c|}{$0.47 \%$} & \\
\hline 1992. & $6,301,252$ & 509,868 & $13,135,997$ & 0 & 492,481 & $3,101,626$ & $23,541,224$ & $2.09 \%$ & \multicolumn{2}{|c|}{$0.35 \%$} & \\
\hline 1993. & $6,834,096$ & 515,108 & $13,840,733$ & 0 & 605,717 & $3,523,084$ & $25,318,738$ & $2.39 \%$ & \multicolumn{2}{|c|}{$0.46 \%$} & \\
\hline 1994. & $8,292,266$ & 527,927 & $14,675,851$ & 0 & 692,476 & $3,806,167$ & $27,994,687$ & $2.47 \%$ & \multicolumn{2}{|c|}{$0.61 \%$} & \\
\hline 1995. & $6,507,582$ & 483,263 & $15,694,169$ & 0 & 623,473 & $4,157,753$ & $27,466,240$ & $2.27 \%$ & \multicolumn{2}{|c|}{$0.46 \%$} & \\
\hline 1996. & $6,672,292$ & 519,380 & $17,569,020$ & 0 & 784,382 & $4,529,799$ & $30,074,873$ & $2.61 \%$ & \multicolumn{2}{|c|}{$0.46 \%$} & \\
\hline 1997. & $6,639,081$ & 522,544 & $17,606,281$ & 0 & 711,619 & $5,079,225$ & $30,558,751$ & $2.33 \%$ & \multicolumn{2}{|c|}{$0.42 \%$} & \\
\hline 1998. & $9,315,096$ & 433,820 & $16,975,793$ & 0 & $1,063,869$ & $5,175,108$ & $32,963,686$ & $3.23 \%$ & \multicolumn{2}{|c|}{$0.60 \%$} & \\
\hline
\end{tabular}

${ }^{a}$ Light oil is distillate fuel oil, and heavy oil is residual fuel oil.

Note: EIA began collecting nonutility data in 1989 and is only final through 1998 . Nonutilities do not directly report the split between light and heavy oil generation.

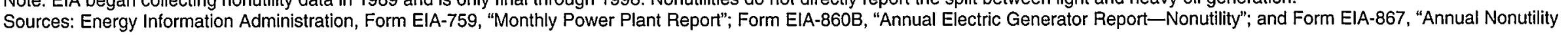
Power Producer Report." 